INSTITUTO DE PESQUISAS ENERGÉTICAS E NUCLEARES

Autarquia associada à Universidade de São Paulo

\title{
SOLDAGEM DE CHAPAS GROSSAS EM AÇO BAIXA LIGA \\ TEMPERADO E REVENIDO ASTM A514 COM AÇO-CARBONO \\ ASTM A36 PELO PROCESSO ARAME TUBULAR
}

\section{MARCELLO FERRARI}

Dissertação apresentada como parte dos requisitos para a obtenção do Grau de Mestre em Ciências na Área de Tecnologia Nuclear - Materiais.

Orientador:

Dr. Maurício David Martins das Neves

SÃO PAULO 
DEDICATÓRIA

Dedico este trabalho ao meu filho Pedro. 


\section{AGRADECIMENTOS}

Agradeço a Deus por não tirar os obstáculos da minha vida, mas sim me dando saúde e força para superá-los.

Ao meu filho Pedro, presente de Deus que ilumina todo o meu caminho.

À minha mãe por tudo e a minha esposa Cláudia pelo apoio e pela compreensão.

Ao Prof. ${ }^{\circ}$ Dr. ${ }^{\circ}$ Maurício David Martins das Neves, qu e me ajudou decisivamente na realização deste trabalho e no meu crescimento acadêmico e profissional.

À Escola de Engenharia Mackenzie pela minha formação.

À Prensas Schuler Brasil, em especial ao Engenheiro Fábio Machado Ávila, por proporcionar as condições necessárias para que eu pudesse cursar o Mestrado.

Ao Inspetor de Soldagem Nível 1 e aluno do Curso Superior em Tecnologia de Soldagem da Faculdade de Tecnologia de São Paulo, Ramon de Souza Dias por ter auxiliado no acompanhamento de soldagem das peças de testes.

Ao Soldador Virnete Gonçalves, por ter soldado as peças de testes.

Ao Engenheiro e Mestrando do IPEN-USP, Marcello Vertamatti Mergulhão, pela ajuda na operação dos equipamentos para a caracterização microestrutural.

Ao Especialista de Soldagem José de Matos Damasceno da Voestalpine-Böhler.

Ao Prof. ${ }^{\circ}$ Ph.D Alexandre Queiroz Bracarense, da Uni versidade Federal de Minas Gerais, a Prof. ${ }^{a}$ Dr. ${ }^{a}$ Daisy M. Almeida da Universidade Federal de Campina Grande e a Dr. ${ }^{-}$Annelise Zeemann da Tecmetal pelas diretrizes quanto a caracterização microestrutural.

A todos aqueles que de algum modo contribuíram para a realização deste trabalho. 


\section{RESUMO}

Neste trabalho foram determinadas as condições para a soldagem de chapas grossas de aço carbono ASTM A36 com aço baixo-liga temperado e revenido ASTM A514 Grau $Q$ empregando-se o processo arame tubular. Para tanto foram soldadas diversas peças de testes com 0 intuito de se avaliar as condições mais adequadas de preparação e soldagem de juntas dissimilares destes materiais. A preparação foi realizada por meio de corte térmico. A temperatura de preaquecimento foi determinada através de modelos matemáticos, pelas recomendações das normas AWS D1.1 e DIN EN 1011-2 sendo posteriormente avaliada por intermédio do teste de soldabilidade tipo CTS - Controlled Thermal Severity. Os parâmetros de soldagem foram determinados a partir da qualificação de um procedimento de soldagem, conforme a norma AWS D1.1. Foram avaliadas as consequências do emprego do tratamento térmico de alívio de tensões após soldagem (TTAT), pelos testes de dureza Vickers e impacto Charpy. A caracterização microestrutural foi realizada por meio de microscopia óptica e microscopia eletrônica de varredura. A caracterização das superfícies oxicortadas evidenciou os efeitos da descarbonetação e também da carbonetação. A temperatura de pré-aquecimento de $160^{\circ} \mathrm{C}$ determinada por meio da metodologia recomendada pelas normas AWS D1.1 e DIN EN 1011-2 mostrou-se satisfatória nos testes de soldabilidade. Foi possível a qualificação do procedimento de soldagem (EPS) com requisitos de impacto na condição "como soldado", porém na condição "após TTAT", os baixos valores de tenacidade obtidos no metal de solda, inferiores a $27 \mathrm{~J}$, não permitiram a qualificação de uma EPS com requisitos de impacto. Foi observada a ausência de trincas intergranulares tanto na zona afetada pelo calor quanto no metal de base ASTM A514, porém foi revelada a presença de microfases frágeis no metal de solda na condição "como soldado", especificamente na região da raiz, intensificadas pelo efeito da diluição. O aumento do teor de carbono na raiz, a presença de microfases frágeis, a grande fração de grãos colunares e de ferrita proeutetóide combinados com a baixa fração de ferrita acicular no metal de solda contribuíram para os baixos valores de tenacidade encontrados na condição "como soldado". Após o TTAT observou-se uma queda acentuada da tenacidade, inferior a $27 \mathrm{~J}$, do metal de solda devido à fragilização provocada pela precipitação e coalescimento de carbonetos de ferro.

Palavras chave: Soldagem de Chapas Grossas; Juntas de Aços Dissimilares; ASTM A514 e Tratamento Térmico de Alívio de Tensões Após Soldagem. 


\begin{abstract}
In this work it was determined the conditions for welding thick plate of ASTM A36 carbon steel with quenched and tempered low-alloy steel ASTM A514 Grade Q employing the Flux Cored Arc Welding (FCAW) process. For that several coupons of tests were welded in order to evaluate the most appropriate conditions for preparation and welding of these dissimilar materials. The preparation was carried out by means of thermal cutting. The preheat temperature was determined by mathematical models, the recommendations of standards AWS D1.1 and DIN EN 1011-2 being further evaluated using the CTS type weldability test - Controlled Thermal Severity. The welding parameters were determined by qualifying a welding procedure (WPS), according to AWS D1.1. The effects of post weld heat treatment (PWHT) were evaluated by Vickers hardness tests and Charpy. Microstructural characterization was performed by optical microscopy and scanning electron microscopy. The characterization of oxi-fuel cut surfaces showed the effects of decarburization and also carburization. The preheating temperature of $160^{\circ} \mathrm{C}$ determined by calculation and the methodology recommended by the standards was satisfactory in weldability tests. It was possible qualification of welding procedure (WPS) with impact requirements in the condition "as welded" but the condition "after PWHT" low toughness values obtained in the weld metal, less than 27J, did not allow to qualify a WPS with toughness requirements. The absence of intergranular cracking was observed in both the heat affected zone as the base metal ASTM A514, but the presence of fragile microphase in the weld metal was revealed in the weld metal in the condition "as welded" specifically in the root region, intensified by the effect of dilution. The carbon increase at root, the presence of fragile microphase, the large fraction of columnar grains and proeutectoid ferrite combined with the low fraction of acicular ferrite in the weld metal contributed to the low toughness values found in the condition "as welded ". After PWHT there was a sharp drop in toughness, less than 27J, in the weld metal due to embrittlement caused by precipitation and coarsening of iron carbides.
\end{abstract}

Key words: Thick Plates Welding; Dissimilar Steels Welded Joints; ASTM A514 and Post Weld Heat Treatment. 


\section{LISTA DE FIGURAS}

Figura 1 - (a) Macroestrutura de uma chapa de ASTM A36 com $200 \mathrm{~mm}$ de espessura. (b) Microestrutura a meio-raio apresentando morfologia dendrítica ............. 1 Figura 2 - (a) Detalhe das chapas de conexão em A514 dos mancais de rolamento. (b) Veículo de transporte CAT Face Hauler FH120............................................... 6 Figura 3 - Componentes estruturais em A514 destinados a equipamentos de movimentação e elevação de cargas 6

Figura 4 - (a) Os parâmetros relativos ao ciclo térmico de soldagem no ponto "A" próximo à solda. (b) Gráfico de distribuição de temperaturas na junta soldada,

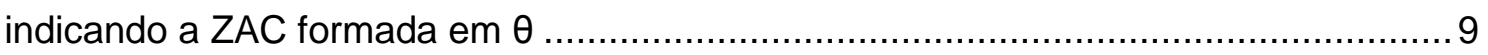

Figura 5 - Os quatro tipos de transferência de calor na soldagem de chapas. ........... 10

Figura 6 - Sistema de coordenadas $(x, y, z)$ movendo-se com a fonte de calor ...........11

Figura 7 - Transferência de calor na condição 3D para uma peça semi-infinita........... 13

Figura 8 - Principais regiões de uma junta soldada ............................................. 14

Figura 9 - Mecanismos operantes na decomposição da austenita ............................ 15

Figura 10 - Diagrama CCT para um metal de solda de aço baixo-carbono ................. 16

Figura 11 - Microestruturas típicas do metal de solda de aço baixo-carbono ..............16

Figura 12 - Microestrutura constituída predominantemente por ferrita acicular ..........17

Figura 13 - Ilustração esquemática mostrando o efeito da adição de elementos de liga, tempo de resfriamento de 800 a $500^{\circ} \mathrm{C}$, conteúdo de oxigênio e tamanho de grão

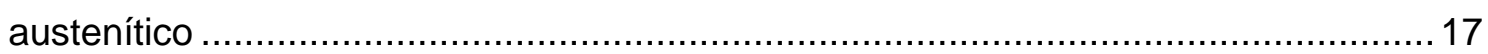

Figura 14 - Efeito dos elementos de liga, tamanho de grão e conteúdo de oxigênio nos diagramas CCT para metal de solda de aço baixo-carbono...................................... 18

Figura 15 - Curvas de transição Charpy para diversos metais de solda .....................20

Figura 16 - Variação da tenacidade Charpy a $-25^{\circ} \mathrm{C}$ para juntas duplo "V" soldadas na posição vertical com eletrodo E7016 e aporte de calor de $3,8 \mathrm{kJmm}^{-1}$..................21

Figura 17 - Esquema mostrando as várias zonas que podem ser formadas na ZAC de um aço-carbono contendo $0,15 \% \mathrm{C}$

Figura 18 - (a) Solubilidade do hidrogênio no ferro com base na temperatura (b) Evolução do hidrogênio com base na temperatura e tempo a partir de uma amostra de metal depositado por soldagem .............................................................. 24

Figura 19 - Mecanismo de fragilização por hidrogênio durante a soldagem ...............25 Figura 20 - Trincas a frio induzidas por hidrogênio. Em (a) tem-se um metal de adição de maior temperabilidade do que o metal de base e a trinca ocorreu na solda. Em (b), um metal de adição de menor temperabilidade do que o metal de base e as trincas ocorreram na ZAC 
Figura 21 - Dimensões principais da peça de testes CTS - Controlled Thermal Severity Test.

Figura 22 - Variação do LR em função do parâmetro H para o aço ASTM A387-11-2, $\mathrm{N}+\mathrm{T}$, em várias condições de TTAT.

Figura 23 - (a) Ilustração esquemática do processo de oxicorte - OFC. (b) Detalhe do oxicorte de uma chapa grossa de $350 \mathrm{~mm}$..... 31

Figura 24 - Microestruturas formadas após corte térmico 32 Figura 25 - (a) Ilustração esquemática do processo FCAW. (b) Detalhe da região da poça de fusão 33

Figura 26 - Geometria do arame e aspecto do fluxo em um corte transversal de uma amostra de arame tubular E71T-1C com bitola de 1,2 mm . 34 Figura 27 - Dimensões das peças de testes PT-01 e PT-02 e locais de remoção dos corpos de prova

Figura 28 - (a) Corpos de prova para determinação do hidrogênio difusível do metal de solda. (b) Detalhe do cromatógrafo JUWE - M Mat221 40

Figura 29 - Peça de testes do tipo CTS - Controlled Thermal Severity....

Figura 30 - Preparação das peças de testes tipo CTS para remoção dos corpos de prova destinados ao exame macrográfico.

Figura 31 - (a) Detalhe da preparação da junta K na condição 1/3 e 2/3 para posterior goivagem da raiz. (b) Peça de testes PT-01/PT-02 soldada e com o reforço de solda removido para posterior inspeção por ultra-som 44 Figura 32 - Localização dos pontos de medição de dureza Vickers HV5 conforme norma PETROBRAS N-133 rev.K.

Figura 33 - Locais de remoção dos corpos de prova para ensaio de impacto Charpy, conforme 4.40 da norma AWS D1.1/D1.1M:2010.

Figura 34 - Locais de remoção dos corpos de prova micrografia 48

Figura 35 - (a) Macrografia PT-01 (A36). (b) Macrografia PT-02 (A514) .................... 50

Figura 36 - (a) e (b) Microestrutura da ZAC, PT-01 (ASTM A36), MO .......................51

Figura 37 - (a) e (b) Microestrutura da ZAC, PT-02 (ASTM A514), MO ..................... 52

Figura 38 - Formação das faixas carbonetadas e descarbonetadas no oxicorte ........54

Figura 39 - Gráfico do perfil de durezas Vickers HV5, PT-01 e PT-02......................... 55

Figura 40 - Variação das taxas de resfriamento com o aporte de calor .......................59

Figura 41 - Temperatura de pré-aquecimento em função da espessura da chapa.....60 Figura 42 - Indicação linear (trinca) na solda 3D da peça de testes PT-03A2 (CTS) após ensaio de líquido penetrante.

Figura 43 - Macrografia da peça de testes PT-03A2 (a) e detalhe ampliado da indicação linear (trinca) na ZAC e MS (b). 
Figura 44 - (a) Pontos de medição de microdureza na macrografia da peça de testes PT-03A2. (b) Detalhe da indicação linear (trinca). Aumento 10X.

Figura 45 - Gráfico comparativo dos limites de resistência dos corpos de prova removidos das peças de testes PT-04 (CS) e PT-05 (TTAT) após ensaio de tração... 65 Figura 46 - Aspecto dos corpos de prova de tração após ensaio

Figura 47 - Detalhe da descontinuidade encontrada no metal de solda após ensaio de dobramento lateral no corpo de prova DL04/PT-05

Figura 48 - Macrografia da peça de testes PT-04 destacando as linhas de segregação. Ataque: Nital 5\%.

Figura 49 - Gráfico comparativo dos perfis de dureza medidos na PT-04 (CS) 69

Figura 50 - Gráfico comparativo dos perfis de dureza medidos na PT-05 (TTAT) ......70 Figura 51 - Gráfico comparativo dos valores de energia abosrvida pelos corpos de prova removidos das peças de testes PT-04 (CS) e PT-05 (TTAT) após ensaio de impacto Charpy $\mathrm{a}-20^{\circ} \mathrm{C}$.

Figura 52 - Gráfico comparativo dos valores de expansão lateral medidos nos corpos de prova removidos das peças de testes PT-04 (CS) e PT-05 (TTAT) após ensaio de impacto Charpy a - $20^{\circ} \mathrm{C}$ 73

Figura 53 - Aspecto da fratura dos corpos de prova do ensaio de impacto Charpy a - 20 C nas condições CS (acima) e TTAT (abaixo) - M etal de solda

Figura 54 - Aspecto da fratura dos corpos de prova do ensaio de impacto Charpy a ${ }^{20} \mathrm{C}$ nas condições CS (acima) e TTAT (abaixo) - ZAC a 1 mm da LF A36 (2.1 a 2.3) e ZAC a $1 \mathrm{~mm}$ da LF A514 (3.1 a 3.3)..

Figura 55 - Aspecto da fratura dos corpos de prova do ensaio de impacto Charpy a ${ }^{20} \mathrm{C}$ nas condições CS (acima) e TTAT (abaixo) - ZAC a 5 mm da LF A36 (4.1 a 4.3) e ZAC a $5 \mathrm{~mm}$ da LF A514 (5.1 a 5.3)..

Figura 56 - Gráfico comparativo dos valores de expansão lateral medidos nos corpos de prova removidos das peças de testes PT-04 (CS) e PT-05 (TTAT) após ensaio

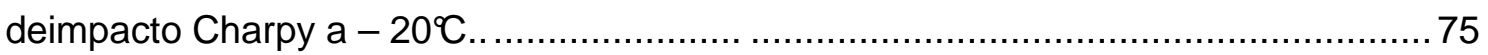

Figura 57 - Fractografia de corpos de prova Charpy do metal de solda (a) condição CS (b) condição após TTAT, 1000 X, MEV. 76

Figura 58 - Fractografia de corpos de prova Charpy do metal de solda (a) condição CS (b) condição após TTAT, 5000 X, MEV. 77 Figura 59 - Fractografia do corpo de prova Charpy (1.1) do metal de solda. Possível inclusão de escória (a) 100 X (b) 500 X, MEV. 77 Figura 60 - Diagramas TTT e CCT para a composição química do aço ASTM A36 utilizado neste trabalho. 78 
Figura 61 - Microestrutura - região A - linha de fusão A36 x MS, condição CS,

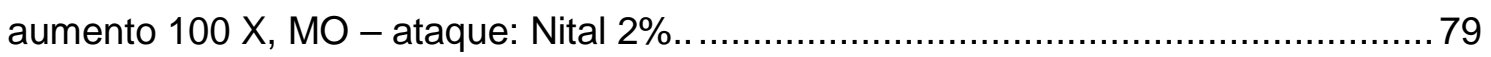

Figura 62 - Microestrutura - região A - linha de fusão A36 x MS, condição CS, aumento $500 \mathrm{X}, \mathrm{MO}$ - ataque: Nital $2 \%$..

Figura 63 - Microestrutura - região A - linha de fusão A36 x MS, condição TTAT, aumento $100 \mathrm{X}, \mathrm{MO}$ - ataque: Nital $2 \%$..

Figura 64 - Microestrutura - região A - linha de fusão A36 x MS, condição TTAT, aumento $500 \mathrm{X}, \mathrm{MO}$ - ataque: Nital $2 \%$..

Figura 65 - Diagramas TTT e CCT para a composição química do aço ASTM A514 GR.Q utilizado neste trabalho

Figura 66 - Microestrutura - região B - linha de fusão A514 x MS, condição CS, aumento $500 \mathrm{X}, \mathrm{MO}$ - ataque: Nital $2 \%$.

Figura 67 - Microestrutura - região B - linha de fusão A514 x MS, condição TTAT, aumento $500 \mathrm{X}, \mathrm{MO}$ - ataque: Nital $2 \%$

Figura 68 - Microestrutura - região C (raiz) - metal de solda, condição CS, aumento 500 X, MO - ataque: Nital $2 \%$

Figura 69 - (a) Macrografia da região C (raiz) indicando a posição do entalhe dos corpos de prova Charpy, ataque: Nital 5\%. (b) Análise química do metal de solda realizada na superfície fratura do corpo de prova Charpy.

Figura 70 - Microestrutura - região C (raiz) - metal de solda, condição CS, aumento 500 X, MO - ataque: LePera modificado...

Figura 71 - Dureza de microestruturas martensíticas em função do teor de carbono no aço.

Figura 72 - Microfases M-A-B - região C (raiz) - metal de solda, condição CS, aumento 1000 X (a) e 2500 X (b), MEV - ataque: LePera modificado....

Figura 73 - Microestrutura - região C (raiz) - metal de solda, condição CS, aumento $500 \mathrm{X}, \mathrm{MO}$ - ataque: LePera modificado.

Figura 74 - Carbonetos - região C (raiz) - metal de solda, condição TTAT, aumento 1000 X, MO - ataque: Picral..

Figura 75 - Carbonetos - região C (raiz) - metal de solda, condição TTAT, aumento 500 X, MEV - ataque : LePera modificado...

Figura 76 - Perfil de composição de região contendo carboneto - região $C$ (raiz) metal de solda, condição TTAT, MEV - ataque: LePera modificado.

Figura 77 - Perfil de composição de região contendo carboneto - região $C$ (raiz) metal de solda, condição TTAT, MEV - ataque: LePera modificado. 90

Figura 78 - Perfil de composição de região contendo carboneto - região C (raiz) metal de solda, condição TTAT, MEV - ataque: LePera modificado. .90 


\section{LISTA DE TABELAS}

Tabela 1 - Composição química ASTM A36 para chapas de 65 a $100 \mathrm{~mm}$ 5

Tabela 2 - Composição química ASTM A514 Grau Q para chapa de espessura 150 mm máximo.

Tabela 3 - Composição química das chapas de testes ............................................ 36

Tabela 4 - Propriedades mecânicas das chapas de testes.................................... 36

Tabela 5 - Composição química do metal depositado - Arame tubular E71T-1 ........ 37

Tabela 6 - Propriedades mecânicas do metal depositado - Arame Tubular E71T-1 .. 37

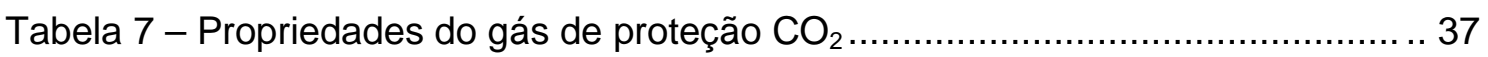

Tabela 8 - Parâmetros de soldagem dos CP's para determinação do hidrogênio difusível no metal de solda......................................................................... 40

Tabela 9 - Parâmetros de soldagem das peças de testes tipo CTS …..................... 42

Tabela 10 - Parâmetros de soldagem das peças de testes PT-04 e PT-05 ............... 44

Tabela 11 - Parâmetros de tratamento térmico da PT-05...................................... 45

Tabela 12 - Normas aplicáveis aos ensaios mecânicos e metalográficos ................. 46

Tabela 13 - Normas aplicáveis aos ensaios mecânicos e metalográficos ................ 46

Tabela 14 - Análise química do produto - Chapa ASTM A36................................ 49

Tabela 15 - Análise química do produto - Chapa ASTM A514 grau Q.................... 49

Tabela 16 - Análise do teor de hidrogênio difusível máximo -E71T1-C ................... 57

Tabela 17 - Ensaios de microdureza Vickers - Junta soldada 3D - PT-03A2 .......... 62

Tabela 18 - Ensaio de tração - PT-04 (CS) e PT-05 (TTAT) .................................... 64

Tabela 19 - Ensaio de dobramento lateral - PT-04 (CS) e PT-05 (TTAT) .................. 66

Tabela 20 - Perfil de durezas - PT-04 (CS) e PT-05 (TTAT) .................................. 68

Tabela 21 - Ensaio de impacto Charpy - PT-04 (CS) e PT-05 (TTAT) ..................... 70

Tabela 22 - Expansão lateral Ensaio Charpy (-20C) - PT-04 (CS) e PT-05 (TTAT).. 73

Tabela 23 - Porcentagem de fratura dúctil Ensaio Charpy $\left(-20^{\circ} \mathrm{C}\right)$ - PT-04 (CS) e PT-

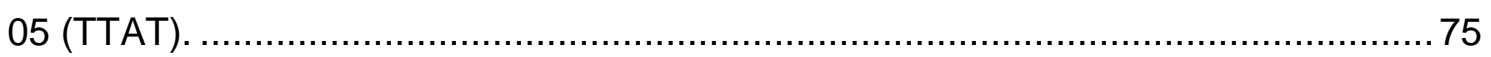

Tabela 24 - Análise química do metal de solda na raiz ....................................... 85 
LISTA DE SÍMBOLOS, SIGLAS E ABREVIATURAS

ARBL: $\quad$ Alta Resistência Baixa-Liga

AISI: $\quad$ American Iron and Steel Institute

ASTM: $\quad$ American Society For Testing And Materials

ASM: $\quad$ American Society of Materials

AWS: $\quad$ American Welding Society

CCT: Continuous Cooling Transformation

CE: $\quad$ Carbono Equivalente

CNC: $\quad$ Comando Numérico Computadorizado

CP: $\quad$ Corpo de Prova

CTS: $\quad$ Controlled Thermal Severity

DIN: Deutsches Institut Normung

EN: $\quad$ European Norm

END: $\quad$ Ensaios Não Destrutivos

EPS: $\quad$ Especificação de Procedimento de Soldagem

FCAW-G: $\quad$ Flux Cored Arc Welding - Gas Shielded

FCAW-S: $\quad$ Flux Cored Arc Welding - Self Protected

GMAW: $\quad$ Gas Metal Arc Welding

GTAW: $\quad$ Gas Tungsten Arc Welding

HSLA: $\quad$ High Strength - Low Alloy

HV: $\quad$ Hardness Vickers

IIW: International Institute of Welding

LE: $\quad$ Limite de Escoamento

LF: $\quad$ Linha de Fusão

LR: $\quad$ Limite de Resistência

M-A: $\quad$ Martensita - Austenita

MB: $\quad$ Metal de Base

MEV: $\quad$ Microscópio Eletrônico de Varredura

MO: $\quad$ Microscópio Óptico 
MS: $\quad$ Metal de Solda

OFC: $\quad$ Oxyfuel Gas Cutting

PETROBRAS: Petróleo Brasileiro S/A

PHWT: $\quad$ Post Weld Heat Treatment

PT: $\quad$ Peça de Testes

RA: $\quad$ Redução de Área

SAE: $\quad$ Society of Automotive Engineers

SAW: $\quad$ Submerged Arc Welding

SMAW: $\quad$ Shielded Metal Arc Welding

THD: $\quad$ Teor de Hidrogênio Dissolvido

TMCR: $\quad$ Thermomechanical Controlled Rolling

TTAT: $\quad$ Tratamento Térmico de Alívio de Tensões

TTT: Time-Transformation-Temperature

US: $\quad$ Ultrassom

WPS: $\quad$ Welding Procedure Specification

ZAC: $\quad$ Zona Afetada pelo Calor

ZF: $\quad$ Zona Fundida 


\section{SUMÁRIO}

DEDICATÓRIA

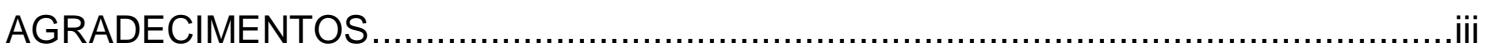

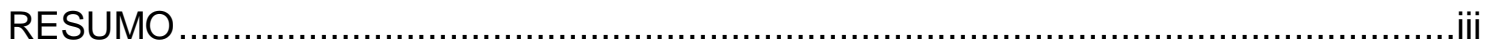

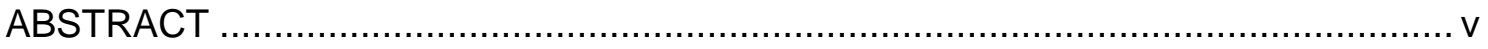

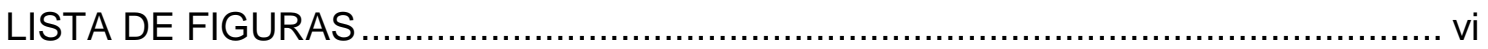

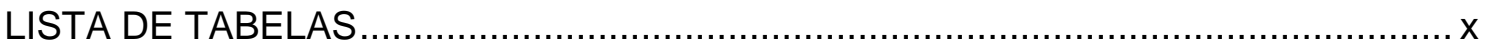

LISTA DE SÍMBOLOS, SIGLAS E ABREVIATURAS ......................................... xi

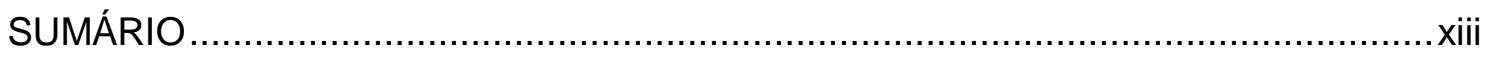

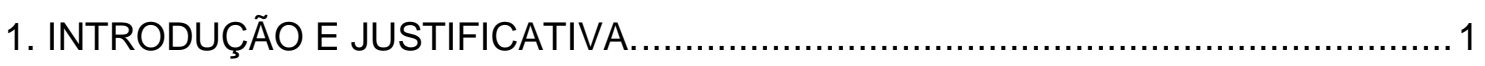

2. OBJETIVO

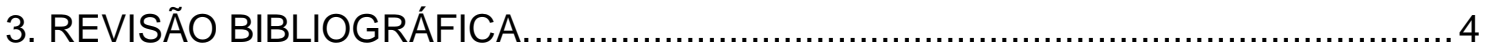

3.1. Aços carbono e aços de alta resistência e baixa-liga. .......................................... 4

3.1.1. Aço carbono estrutural - ASTM A36 ................................................... 5

3.1.2. Aço carbono de alta resistência e baixa-liga - ASTM A514. ......................... 4

3.2. Transferência de calor na soldagem de chapas grossas.................................... 7

3.2.1. Ciclo térmico e distribuição do calor na soldagem...................................... 8

3.2.2. Definição de chapa grossa............................................................... 9

3.2.3. Equação de Rosenthal para chapas grossas. ............................................. 11

3.3. Microestrutura e tenacidade de uma junta soldada....................................... 14

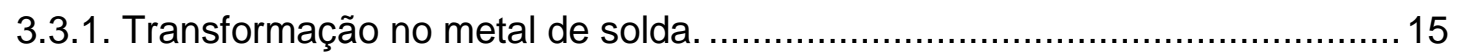

3.3.2. Tenacidade no metal de solda. ................................................................... 18

3.3.3. Transformação na Zona Afetada pelo Calor (ZAC) . ................................... 20

3.3.4. Constituinte M-A e a sua influência na tenacidade de juntas soldadas...........23

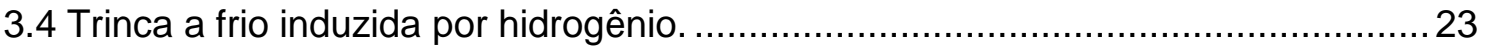

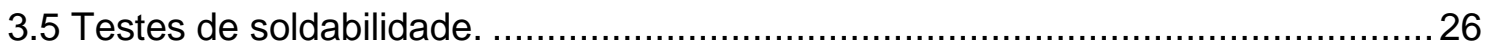

3.6 Tratamento térmico de alívio de tensões após soldagem....................................27

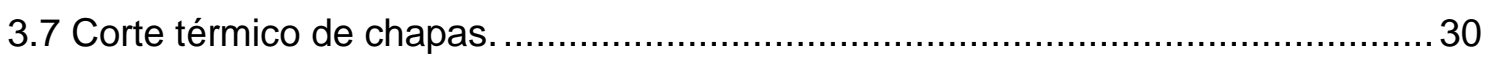

3.8 Processos de soldagem para juntas ASTM A36 X ASTM A514 ........................... 33

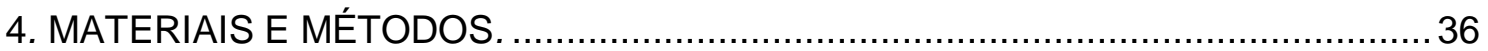

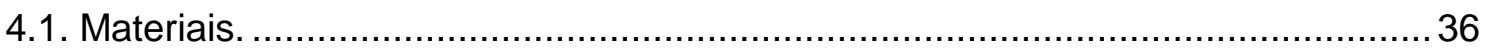

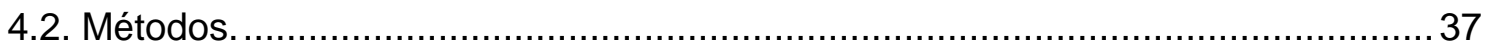

4.2.1. Caracterização do metal de base (MB) e do metal de adição (MA)............... 37

4.2.1.1. Análise da composição química das chapas. ........................................... 38

4.2.1.2. Determinação da espessura mínima a ser removida faces oxicortadas. .... 38 
4.2.1.3. Determinação do hidrogênio difusível no metal de adição.......................... 39

4.2.1.4. Determinação da temperatura mínima de preaquecimento. ......................40

4.2.2. Preparação e qualificação da soldagem.................................................... 43

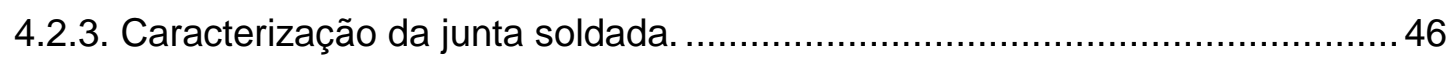

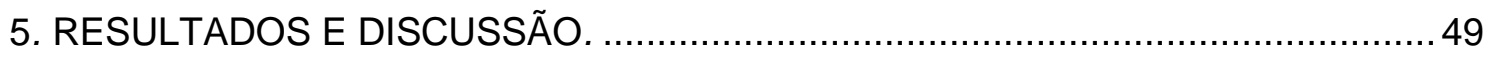

5.1. Caracterização do metal de base (MB) e do metal de adição (MA) ...................... 49

5.1.1. Análise da composição química das chapas............................................. 49

5.1.2. Determinação da espessura mínima a ser removida faces oxicortadas. ........50

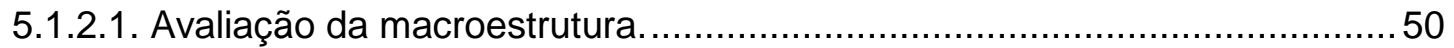

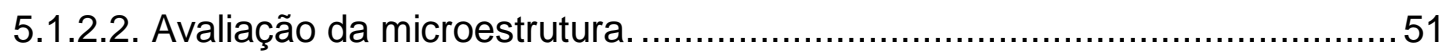

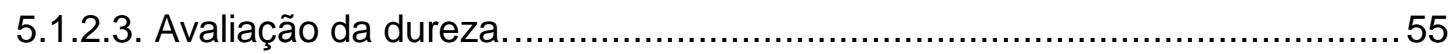

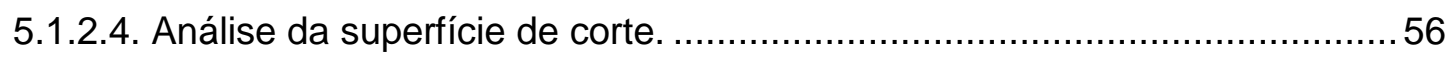

5.1.3. Análise do hidrogênio difusível do consumível. ..........................................56

5.1.4. Determinação da temperatura mínima. ....................................................... 58

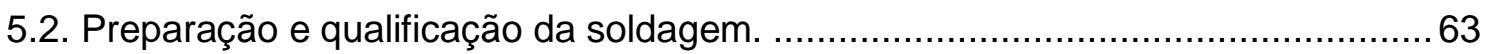

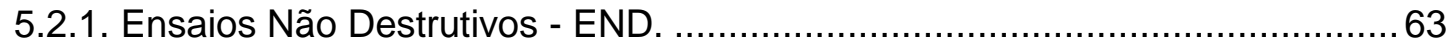

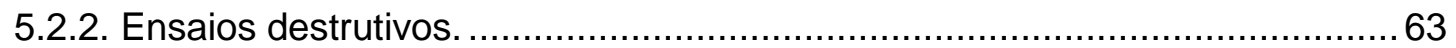

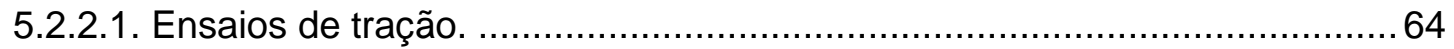

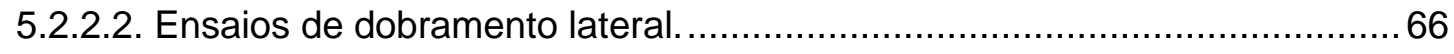

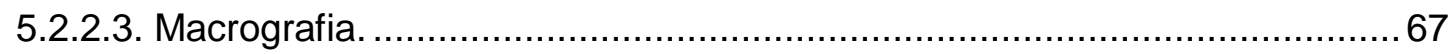

5.2.2.4. Considerações finais sobre a qualificação da soldagem. ..........................68

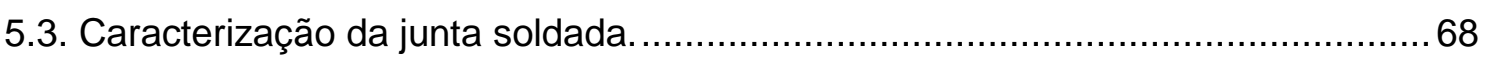

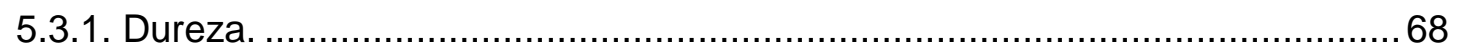

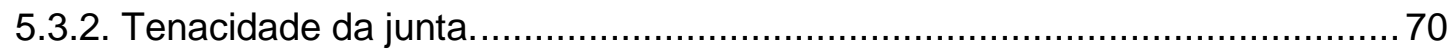

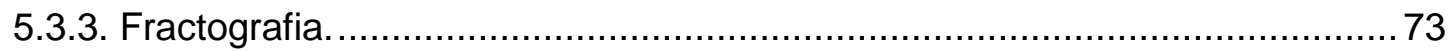

5.3.4. Microestrutura e correlação com a tenacidade............................................. 78

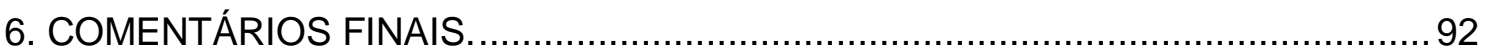

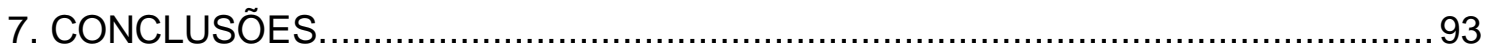

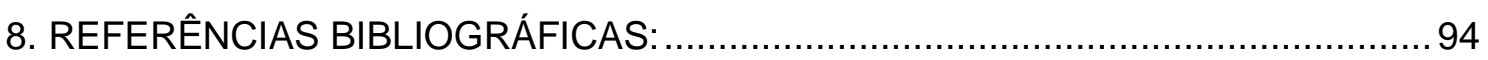




\section{INTRODUÇÃO E JUSTIFICATIVA}

Os aços de alta resistência têm sido empregados largamente na construção de estruturas metálicas sujeitas a elevados esforços, tais como, equipamentos de construção, mineração, movimentação de cargas e bases de turbinas. Nestes casos, o emprego de aços de alta resistência pode ser mais econômico por usar menores espessuras e menor peso do equipamento, o que resulta menor quantidade de aço e também menor quantidade de soldagem. A menor espessura em alguns casos torna dispensável o tratamento térmico de alívio de tensões, que é outro fator de redução do custo da estrutura. Em alguns equipamentos para solicitações muito elevadas, o uso dos aços de alta resistência pode ser a única solução viável, uma vez que, com espessuras grandes (acima de $100 \mathrm{~mm}$ ) as operações de conformação, soldagem, tratamentos térmicos, montagem e controle de qualidade tornam-se caras e difíceis ou até mesmo impossíveis. Para essas espessuras é também grande a tendência a fraturas frágeis e à ocorrência de defeitos internos no material [1]. Na Figura 1 é mostrada uma chapa grossa de ASTM A36 [2] com $200 \mathrm{~mm}$ de espessura que apresenta forte segregação de impurezas na região central e também uma estrutura heterogênea, decorrente da insuficiente taxa de redução durante a laminação.
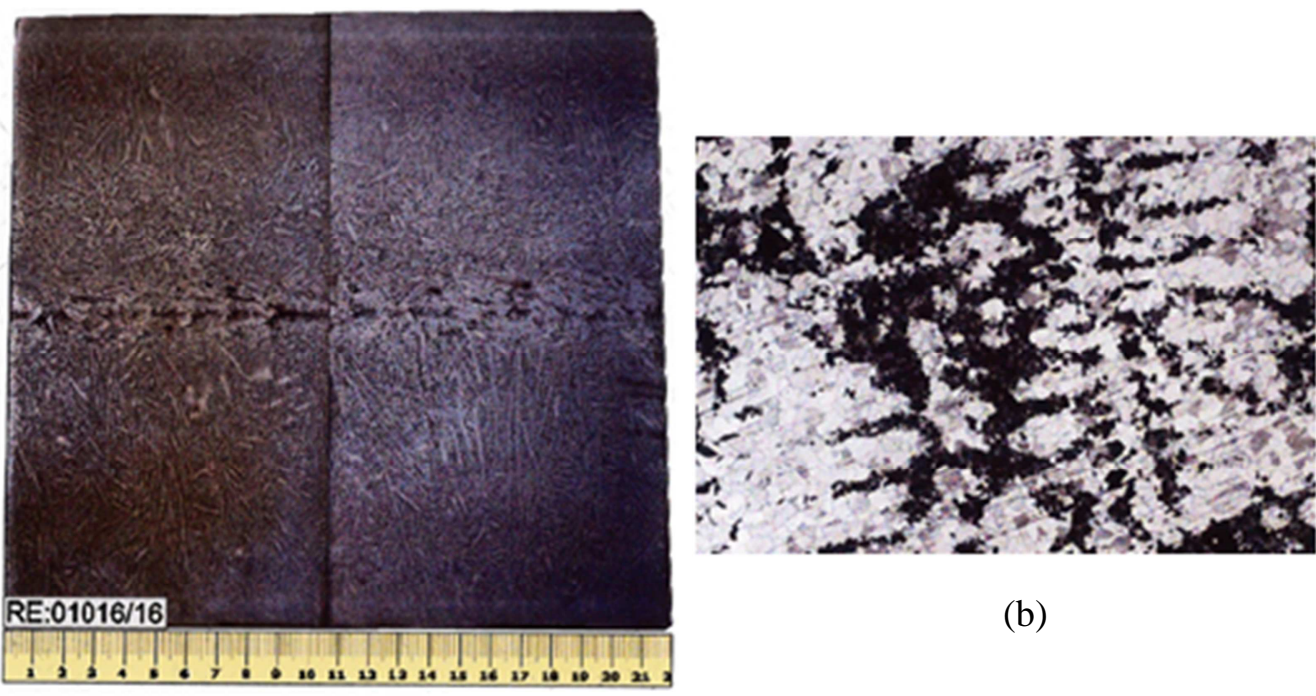

(a)

Figura 1 - (a) Macroestrutura de uma chapa grossa de ASTM A36 com 200 mm de espessura. (b) Microestrutura a meio raio apresentando morfologia dendrítica. Fonte: o autor.

Deste modo, um aço de alta resistência torna-se muitas vezes uma opção mais vantajosa do que o emprego de aços carbonos comuns. Dentro deste contexto, o aço 
ASTM A514 [3] assume uma posição de destaque. Trata-se de um aço baixa-liga, temperado e revenido com tensões mínimas de resistência à ruptura e de escoamento, respectivamente, de $895 \mathrm{MPa}$ e $690 \mathrm{MPa}$. Estes níveis de resistência chegam a superar aos dos aços carbono comuns em quase três vezes. Este aço possui um alongamento mínimo de $16 \%$ e adequada tenacidade a baixas temperaturas, além de apresentar razoável soldabilidade, mesmo apresentando uma microestrutura martensítica [3,4].

Entretanto, com relação ao aspecto da soldabilidade, são requeridos alguns cuidados antes, durante e após a soldagem. Tais cuidados devem ser ainda maiores, considerando-se que mesmo com o emprego de aços de alta resistência, ainda ocorram situações onde há a necessidade do emprego de elevadas espessuras podendo chegar até $150 \mathrm{~mm}$ no caso ASTM A514. Além do aspecto metalúrgico, esta é uma condição muito crítica visto que, grandes espessuras potencializam a formação de trincas em razão das condições de transferência de calor existentes e também das elevadas tensões residuais internas criadas durante a operação de soldagem.

A propósito deste ultimo fator, muitas vezes, não é recomendado o tratamento térmico de alívio de tensões após soldagem para estes aços, pela fragilização decorrente da redução da tenacidade na zona afetada pelo calor. Na norma AWS D1.1 [5] existe a recomendação de não empregar o tratamento térmico de alívio de tensões para este aço.

Outra dificuldade encontrada na soldagem destes aços é a susceptibilidade à fragilização por hidrogênio. Para contornar este problema, tanto nas normas AWS D1.1 quanto na N133 da PETROBRAS [6] são estabelecidas algumas recomendações no que diz respeito ao preaquecimento e também ao emprego de consumíveis de baixo hidrogênio.

O aspecto econômico também é importante visto que, na construção de uma estrutura metálica é imprescindível considerar os custos para se viabilizar um projeto. Assim busca-se sempre o emprego de processos de soldagem de elevada taxa de deposição, onde o processo arame tubular assume nos dias atuais uma posição de destaque pela sua elevada produtividade e pela qualidade das soldas obtidas. $O$ corte e a preparação das superfícies e chanfros das chapas devem ser realizados com recursos usuais de fabricação. Neste ínterim destaca-se o processo oxicorte pela sua versatilidade e baixo custo operacional.

Assim, o desafio para a soldagem destes aços consiste em estabelecer um correto balanço entre os aspectos técnicos, os cuidados e as considerações práticas para obter como resultado uma solda com qualidade, livre de descontinuidades, aprovadas por ensaios que constam em normas do setor. 


\section{OBJETIVO}

O objetivo deste estudo é determinar as condições mais adequadas para a soldagem, empregando o processo arame tubular, de chapas grossas de aço baixa liga temperado e revenido ASTM A514 Grau Q com aço carbono ASTM A36 tendo como referência principal a norma AWS D1.1/D1.1M:2010 [5] para o comportamento da junta soldada. 


\section{REVISÃO BIBLIOGRÁFICA}

\subsection{Aços carbono e aços de alta resistência e baixa liga}

Segundo a ASM, como definição geral, um aço é uma liga de ferro, carbono (abaixo de $2 \%$ ) e outros elementos de liga, que é capaz de ser conformado a quente e a frio, ou apenas a quente, em várias formas geométricas [7].

Na prática, porém, a quantidade de carbono nunca é superior a 1,5\% e nos aços empregados nas estruturas metálicas esse valor não ultrapassa $0,35 \%$. Um aço de baixo carbono possui um teor de carbono abaixo de $0,2 \%$.

Os aços carbono de qualidade estrutural são largamente empregados nas construções metálicas. Por aços estruturais, entendem-se, basicamente, vergalhões para reforço de concreto, barras (normalmente em aplicações estáticas), bem como chapas e perfis para aplicações estruturais. Uma grande parte dos aços empregados para a fabricação de equipamentos industriais tais como caldeiras, vasos de pressão e tubulações, é equivalente aos aços estruturais, especialmente para aplicações a temperaturas inferiores a $350^{\circ} \mathrm{C}$, quando a fluência não é uma propriedade determinante na seleção $[1,4,8]$.

Para estruturas e aplicações de maior responsabilidade, aços de alta resistência e baixa liga denominados por ARBL (ou HSLA, em inglês) vêm sendo extensivamente desenvolvidos nas últimas décadas. A classificação de aços como ARBL é bastante genérica e, frequentemente, conduz a mal-entendidos. Por este motivo foram feitas tentativas pela AISI, SAE e ASTM para classificar tais aços. Entretanto, tais classificações ainda são confusas por serem muito abrangentes [7].

De qualquer modo, segundo a ASM, os aços ARBL são um grupo de aços de baixo $(0,2 \%$ C máx.) e médio carbono $(0,2-0,5 \%$ C) que geralmente empregam pequenas quantidades de elementos de liga de modo a se obter tensões de escoamento superiores a $345 \mathrm{MPa}$ nas condições laminado a quente, laminado a frio, recozido, com alívio de tensões, temperados e revenidos ou normalizados [7].

Em alguns casos são chamados de aços microligados em razão das pequenas quantidades de vanádio, nióbio e/ou titânio que são adicionados para refinamento de grão e para auxiliar no endurecimento por precipitação e incrementar algumas propriedades mecânicas. $[7,8]$. 


\subsubsection{Aço carbono estrutural - ASTM A36}

Os aços de qualidade estrutural são destinados basicamente à construção de estruturas metálicas em geral. Destaca-se nesta categoria o aço de especificação ASTM A36 [2] que foi introduzida no mercado em 1960 [4]. Esta especificação é aplicável a produtos na forma de perfis, chapas e barras. De um modo geral esse aço é produzido na condição de totalmente acalmado ao silício ou ao alumínio. Os requisitos básicos de composição química para chapas grossas (de 65 a $100 \mathrm{~mm}$ ) em ASTM A36 estão descritos na Tabela 1.

Tabela 1 - Composição química ASTM A36 para chapas de 65 a $100 \mathrm{~mm}$ Valores em \% - Adaptado de [10]

\begin{tabular}{c|c|c|c|c|c}
\hline C máx. & $\mathrm{Mn}^{A}$ & $\mathrm{P}$ máx. & S máx. & $\mathrm{Si}$ & Cu mín. $^{B}$ \\
\hline 0,27 & $0,85-1,20$ & 0,04 & 0,05 & $0,15-0,40$ & 0,20 \\
\hline
\end{tabular}

${ }^{A}$ Para cada redução de $0,01 \%$ abaixo do máximo teor de carbono especificado, um incremento de $0,06 \%$ acima do teor máximo de manganês será permitido até o limite de 1,35\%.

${ }^{B}$ Quando o aço-cobre é especificado.

O ASTM A36 é considerado um aço de baixa resistência, pois apresenta limite de resistência a tração especificado inferior a $490 \mathrm{MPa}$. A tensão de resistência do A36 encontra-se na faixa de 400-550 MPa, a tensão de escoamento mínima é de 250 MPa (220 MPa para chapas acima de $200 \mathrm{~mm}$ ) e o alongamento mínimo é de $20 \%$ (em $200 \mathrm{~mm}$ ) ou 23\% (em 50 mm). Em geral o ASTM A36 não é especificado com requisito de impacto.

As chapas de ASTM A36 são geralmente produzidas por laminação convencional e fornecidas na condição "como laminado", apresentando microestrutura típica de ferrita e perlita. Estes aços não devem ser empregados em temperaturas superiores a $400{ }^{\circ} \mathrm{C}$ em regime de trabalho contínuo $[1,4,8]$.

\subsubsection{Aço-carbono de alta resistência e baixa liga - ASTM A514}

Os aços-carbono de alta resistência são aqueles que apresentam limites de resistência a tração especificado igual ou superior a $490 \mathrm{MPa}$. É possível se obter chapas de aço com limites de resistência superiores a $690 \mathrm{MPa}$. É o caso do aço de especificação ASTM A514 [3] que foi introduzido no mercado em 1964 [4]. Esta especificação é aplicável somente a produtos na forma de chapas. Este aço é produzido na condição totalmente acalmado e pequeno tamanho de grão austenítico 
(ASTM n.5). Este aço encontra aplicação nos segmentos de máquinas, equipamentos de mineração e estruturas onde são requeridos baixo peso e alta resistência. Nas Figuras 2 e 3 são mostradas algumas aplicações do ASTM A514 na construção de chapas de conexão para mancais de rolamento destinados a veículos especiais de mineração e outros componentes estruturais.

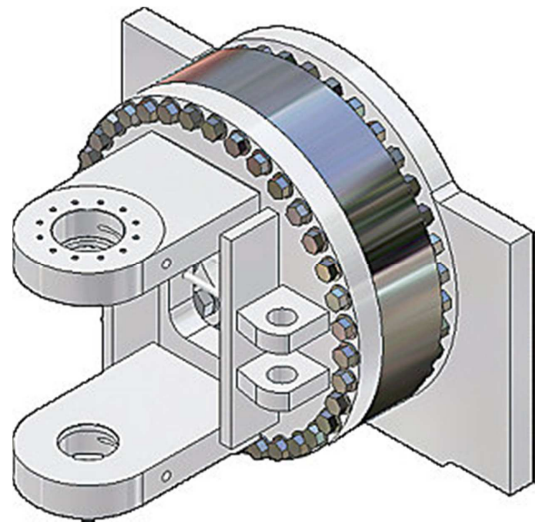

(a)

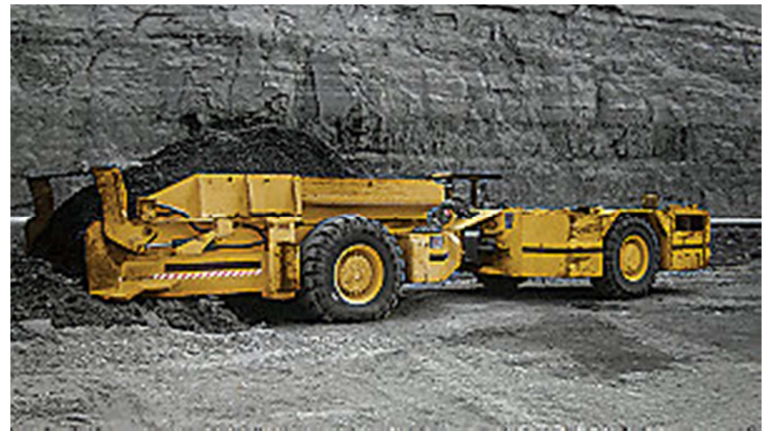

(b)

Figura 2 - (a) Detalhe das chapas de conexão em A514 dos mancais de rolamento. (b) Veículo de transporte CAT Face Hauler FH120. [9]

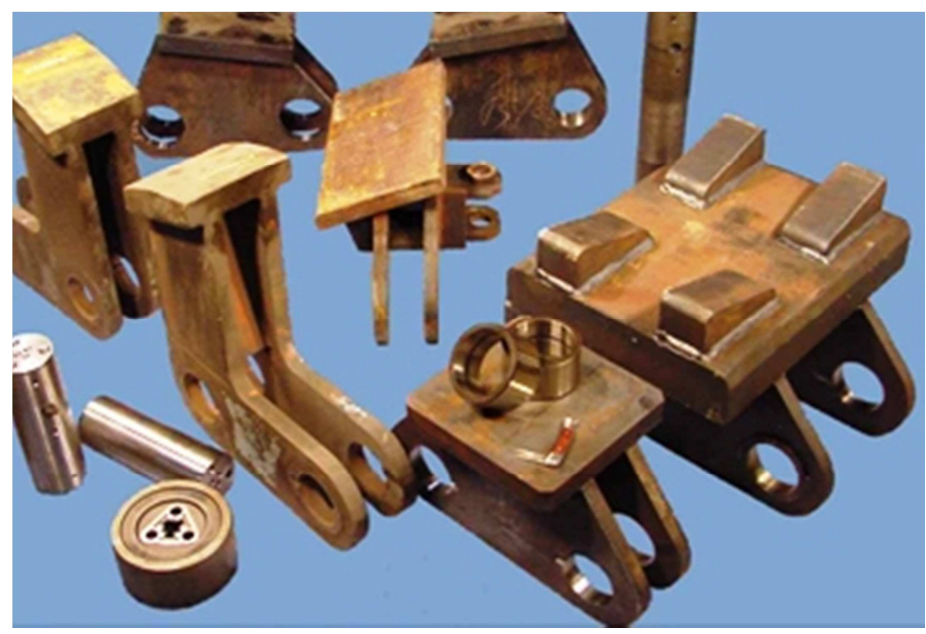

Figura 3 - Componentes estruturais em A514 destinados a equipamentos de movimentação e elevação de cargas [10]

Estes aços apresentam na sua composição química, pequenas adições de elementos de liga, sendo o tipo e as quantidades destas adições dividem esse material em diversos graus, a saber: $A, B, E, F, H, P, Q$ e $S$. Os requisitos básicos de composição química para o ASTM A514 grau Q estão descritos na Tabela 2.

A tensão de resistência do A514 encontra-se na faixa de 760-895 MPa para espessuras até $65 \mathrm{~mm}$ e na faixa de 690-895 para espessura acima de $65 \mathrm{~mm}$ até 150 
mm. A tensão de escoamento mínima é de $690 \mathrm{MPa}$ (620 MPa para espessura acima de $65 \mathrm{~mm}$ até $150 \mathrm{~mm}$ ) e o alongamento mínimo é de 18\%, para espessuras até $65 \mathrm{~mm}$ ou 16\% (acima de 65 até $150 \mathrm{~mm}$ ). Em geral o A-514 não é especificado em aplicações que tenham requisitos de impacto [4].

Tabela 2 - Composição química ASTM A514 Grau Q para chapas de 150 mm máx. Valores em \% - Adaptado de [3]

\begin{tabular}{c|c|c|c|c|c|c|c|c|c}
\hline & $\mathrm{C}$ & $\mathrm{Mn}$ & $\mathrm{P}$ & $\mathrm{S}$ & $\mathrm{Si}$ & $\mathrm{Ni}$ & $\mathrm{Cr}$ & $\mathrm{Mo}$ & $\mathrm{V}$ \\
\hline Mín. & 0,14 & 0,95 & - & - & 0,15 & 1,20 & 1,00 & 0,40 & 0,03 \\
\hline Máx. & 0,21 & 1,30 & 0,035 & 0,035 & 0,35 & 1,50 & 1,50 & 0,60 & 0,08 \\
\hline
\end{tabular}

As chapas de ASTM A514 são produzidas por laminação convencional ou laminação controlada (TMCR), temperados e revenidos apresentando microestrutura típica de martensita revenida. A temperatura de austenitização do material deve ser superior a $900^{\circ} \mathrm{C}$ seguido de resfriamento em água ou óleo e revenido em temperaturas superiores a $620^{\circ} \mathrm{C}$.

Em consequência do baixo teor de carbono a soldagem deste material é relativamente fácil, mesmo considerando a microestrutura martensítica. Por outro lado é difícil manter as propriedades de alta resistência na região afetada pela soldagem, o que exige cuidados e tratamentos especiais [11]. Este aço não é adequado para serviço em temperaturas superiores a $2^{\circ} 00^{\circ}$, tampouco para serviços a baixas temperaturas. Estes aços são susceptíveis às diversas formas de corrosão sob tensão, estando sujeitos a ruptura por corrosão sob tensão quando em presença de $\mathrm{H}_{2} \mathrm{~S}$ mesmo em pequena quantidade. Tratando-se de equipamentos de responsabilidade, não se recomenda o emprego de aços de alta resistência quando houver qualquer possibilidade, ainda que remota, da ocorrência de corrosão sob tensão [1].

\subsection{Transferência de calor na soldagem de chapas grossas}

O calor é elemento essencial na soldagem, porém pode influenciar diretamente nas transformações de fase e assim alterar as microestruturas, consequentemente as propriedades da junta soldada e suas adjacências.

Por este motivo, o entendimento dos fenômenos de transferência de calor na soldagem permite uma melhor compreensão do processo de soldagem como um todo, de modo a ser possível prever a formação de certas microestruturas nas diversas regiões da junta além de, se for o caso, fornecer informações para que seja evitada a formação de determinadas microestruturas. 
Assim, é importante o conhecimento dos ciclos térmicos e da distribuição de temperaturas a que estão submetidas às juntas durante a soldagem, pois estes podem fornecer informações a respeito dos cuidados que devem ser tomados durante 0 processo. Do ponto de vista metalúrgico é fundamental conhecer os picos de temperatura e as velocidades de resfriamento a que são submetidos os materiais, uma vez que, a microestrutura e as propriedades finais da junta dependem destas variáveis $[12,13]$.

O modelamento matemático da transferência de calor na soldagem é bastante complexo em virtude das diversas variáveis que envolvem a fonte de calor e os materiais a serem soldados e, portanto, tais modelos se apoiam em muitas simplificações de modo que ocorrem desvios nas distribuições de temperaturas reais na soldagem comparadas com aquelas calculadas por meio de expressões teóricas. De qualquer modo isto não é importante, visto que os cálculos de transferência de calor na soldagem são requeridos apenas para permitir o entendimento da natureza do processo e para prever tendências de um modo geral $[13,14,15]$.

\subsubsection{Ciclo térmico e distribuição do calor na soldagem}

A curva correspondente do ciclo térmico de soldagem $\theta=f(t)$, (variação da temperatura $\theta$ em função do tempo $t$ ), plotada a partir dos dados do ponto $A$, próxima à solda (Figura 4) fornece as seguintes informações:

- Temperatura máxima alcançada, $\theta_{\mathrm{m}}$;

- Tempo de encharque acima da temperatura $\theta_{S}$;

- Tempo de resfriamento $t_{R}\left(\theta_{1}-\theta_{2}\right)$ entre as temperaturas $\theta_{1}$ e $\theta_{2}$ ou a velocidade de resfriamento $V_{R}$ a temperatura $\theta_{R}$.

Deste modo, num determinado ponto da junta soldada, a magnitude dos valores associados ao ciclo térmico permite o conhecimento ou a antecipação dos fenômenos metalúrgicos que podem ocorrer naquele ponto, tais como modificações microestruturais. Entretanto, muitas vezes é necessário se conhecer a distribuição das temperaturas ao longo do perfil transversal da junta soldada. Trata-se da curva $\theta_{m}=f(x)$ que também é mostrada na Figura 4. Tal curva mostra a variação da temperatura em cada ponto como função da distância $x$.

Com essa curva é possível delimitar as regiões onde ocorrem alterações microestruturais além de ser possível prever a extensão da zona afetada pelo calor 
(ZAC) onde nos aços corresponde a zona de austenitização (pontos $A_{3}$ austenitização completa a $A_{1}$ austenitização parcial).

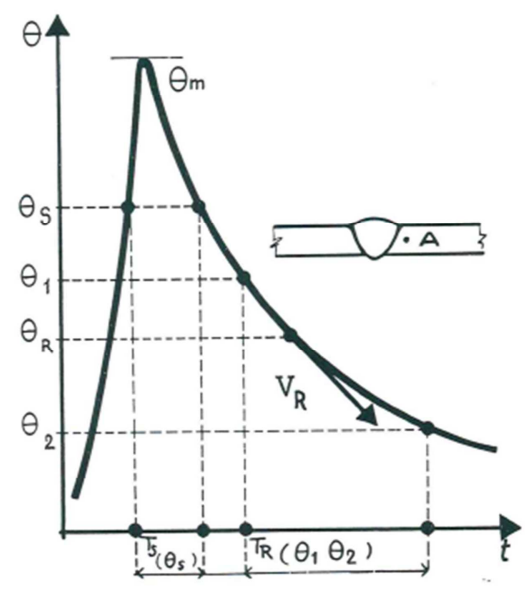

(a)

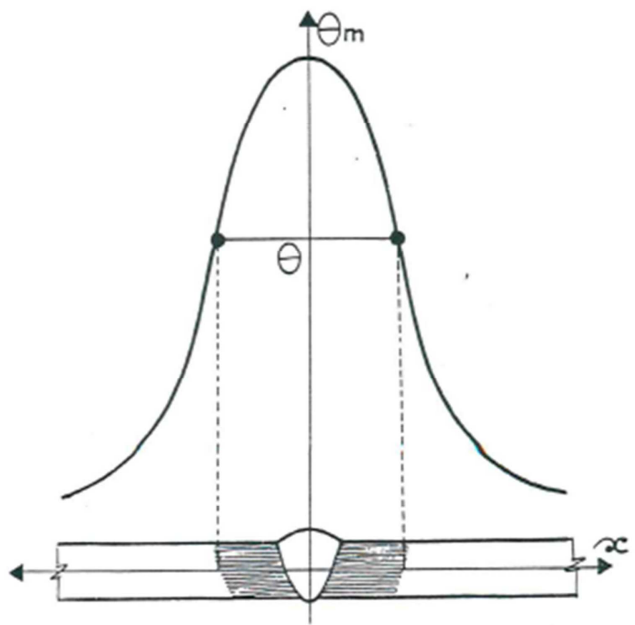

(b)

Figura 4 - (a) Os parâmetros relativos ao ciclo térmico de soldagem $(\theta=f(t))$ no ponto " $A$ " próximo à solda. (b) Gráfico de distribuição de temperaturas na junta soldada, indicando a ZAC formada em $\theta$. Extraído de [14]. Desenho do próprio punho do Granjon.

A determinação destas curvas é possível experimentalmente, através do emprego de termopares, ou por meio de modelos matemáticos, onde se destaca o modelo proposto por Rosenthal [14].

\subsubsection{Definição de chapa grossa}

O efeito dos parâmetros de soldagem nas taxas de resfriamento do metal de solda foi analisado por Rosenthal em 1941 e posteriormente por outros pesquisadores que deixaram contribuições importantes nesta área. Tais estudos estabeleceram que quatro diferentes condições de transferência de calor podem existir no resfriamento da solda, dependendo da espessura relativa da chapa [16]. Estas condições esquematizadas na Figura 5 estão descritas sucintamente a seguir:

a) Chapas Grossas (3D) - o calor é conduzido aproximadamente na direção radial em todas as direções da chapa (tridimensional);

b) Chapas de Espessura Intermediária (2,5D) - Dado o efeito na superfície do fundo da chapa, o fluxo de calor abrange uma faixa de perfis que transitam entre aqueles apresentados pelas chapas grossas e pelas chapas finas;

c) Chapas Finas (2D) - O fluxo do calor na chapas é paralelo as superfícies da chapa (bidimensional); 
d) Chapas Muito Finas (2D+Radiação) - quando as chapas são muito finas, a transferência de calor por radiação e convecção podem tornar-se um fator a ser considerado. Por exemplo, quando chapas muito finas são soldadas com altos aportes de calor, a transferência na superfície é geralmente significante.

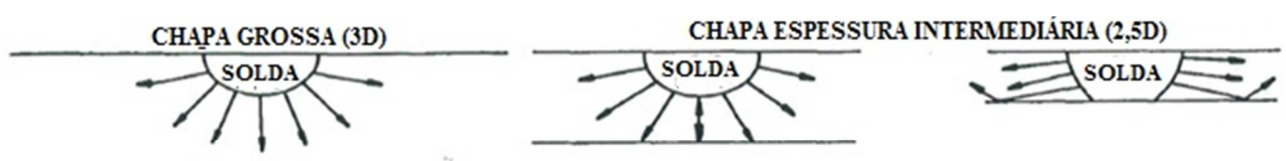

CHAPA FINA, TRANSFERÊNCIA DE CALOR NA SUPERFICIE INSIGNIFICANTE (2D)

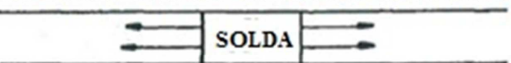

CHAPA MUITO FINA, TRANSFERÊNCIA DE CALOR NA SUPERFICIE SIGNIFICANTE (2D+R)

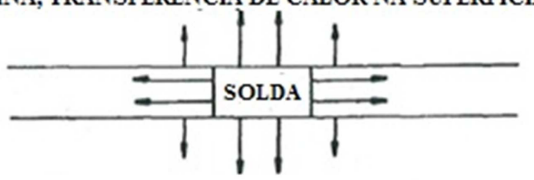

Figura 5 - Os quatro tipos de transferência de calor na soldagem de chapas. Adaptação [16]

Segundo a AWS [17] a definição de espessura de chapa é determinada pelo seguinte critério:

$\tau=e\left[\rho \frac{C p(T p-T o)}{H}\right]^{1 / 2}$

Onde:

$\tau=$ espessura relativa da chapa

$\mathrm{e}=$ espessura da chapa $(\mathrm{mm})$

$\rho=$ densidade $\left(\mathrm{g} / \mathrm{mm}^{3}\right)$

$C p=$ calor específico $\left(\mathrm{J} / \mathrm{g}^{\circ} \mathrm{C}\right)$

$T p=$ temperatura de interesse $\left({ }^{\circ} \mathrm{C}\right)$

To $=$ temperatura inicial da chapa $\left({ }^{\circ} \mathrm{C}\right)$

$H=$ aporte de calor $(\mathrm{J} / \mathrm{mm})$

Para estruturas metálicas:

$\tau<0,6$ : chapa fina (até $6 \mathrm{~mm}$ ) 
$0,6<\tau<0,9$ : chapa média (de 6 até $19 \mathrm{~mm}$ )

$\tau>0,9$ : chapa grossa (acima de $19 \mathrm{~mm}$ )

\subsubsection{Equação de Rosenthal para chapas grossas}

A condução de calor através de um sólido, no domínio do tempo t e referido a um sistema cartesiano triortogonal $(x, y, z)$ pode ser expresso pela Equação 2:

$\frac{\partial}{\partial x}\left[\lambda T \frac{\partial T}{\partial x}\right]+\frac{\partial}{\partial y}\left[\lambda T \frac{\partial T}{\partial y}\right]+\frac{\partial}{\partial z}\left[\lambda T \frac{\partial T}{\partial z}\right]+q o=\rho . c \frac{\partial T}{\partial t}$

Onde:

$\mathrm{T}=$ variável representando a temperatura

$\mathrm{x}, \mathrm{y}, \mathrm{z}=$ coordenadas cartesianas triortogonais

$\mathrm{t}=$ tempo

$\lambda t=$ condutibilidade térmica do material, dependente da temperatura

$\rho=$ densidade do material

$\mathrm{c}=$ calor específico do material no estado sólido

$\mathrm{q}_{\mathrm{o}}=$ fonte ou sorvedouro de calor.

Na Figura 6 é mostrada de forma esquemática a soldagem de uma peça na condição estacionária.

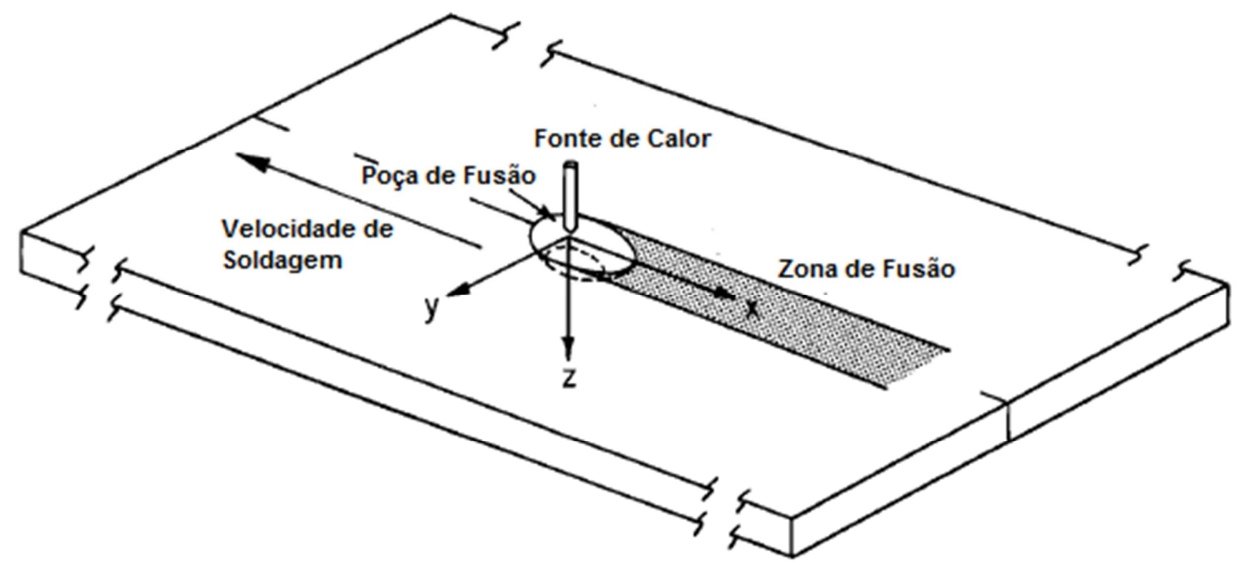

Figura 6 - Sistema de coordenadas $(x, y, z)$ movendo-se com a fonte de calor. Adaptação [13]

A origem do sistema de coordenadas movimenta-se com a fonte de calor a uma velocidade constante " $v$ " na direção negativa do eixo x. Exceto para as condições 
transitórias no inicio e no final da soldagem, a transferência de calor em uma peça de suficiente comprimento é estacionária ou quase-estacionária em relação a movimentação da fonte. Em outras palavras, para um observador movendo-se com a fonte de calor, a distribuição da temperatura e a geometria da poça de fusão não se alteram com o tempo.

Esta hipótese foi assumida por Rosenthal para simplificar o tratamento matemático da transferência de calor na soldagem [12,15]. Ele também fez uso das seguintes hipóteses simplificadoras para a obtenção das equações analíticas para a transferência de calor na soldagem:

1 - transferência de calor quase-estacionária;

2 - fonte de calor pontual;

3 - calor de fusão desprezível;

4 - propriedades térmicas constantes;

5 - sem perdas de calor na superfície da peça;

6 - sem convecção na poça de fusão.

Diante destas hipóteses simplificadoras, pode se considerar a inexistência de fontes ou sorvedouros de calor no interior do material e a condutibilidade térmica deste como constante $\left(\lambda_{T}=\lambda\right)$. Assim, a Equação 2 pode ser escrita da seguinte forma:

$\lambda\left[\frac{\partial^{2} T}{\partial x^{2}}+\frac{\partial^{2} T}{\partial y^{2}}+\frac{\partial^{2} T}{\partial z^{2}}\right]=\rho . c \frac{\partial T}{\partial t}$ ou $\boldsymbol{\nabla}^{2} T=\frac{1}{k} \frac{\partial T}{\partial t}$

Onde a expressão $\mathrm{k}=\lambda / \rho \mathrm{c}$ é denominada difusividade térmica do material.

Considerando o regime semi-estacionário, tem-se:

$\nabla^{2} T=\frac{v}{k} \frac{\partial T}{\partial x}$

A solução de Rosenthal para esta equação na condição de transferência de calor em chapas grossas (3D) [13] é:

$$
T=\frac{Q}{2 \pi K r} e^{-v(r-x) / 2 k}
$$


Onde:

$\mathrm{T}=$ temperatura

$\mathrm{K}$ = condutividade térmica da peça

$\mathrm{Q}=$ calor transferido da fonte de calor para a peça

$\mathrm{V}=$ velocidade de soldagem

$\mathrm{k}=$ difusividade térmica do material da peça

$\mathrm{r}=$ distância radial a partir da origem, a saber: $\left(\mathrm{x}^{2}+\mathrm{y}^{2}+\mathrm{z}^{2}\right)^{1 / 2}$

Na Figura 7 é ilustrada esquematicamente a soldagem de uma chapa grossa.

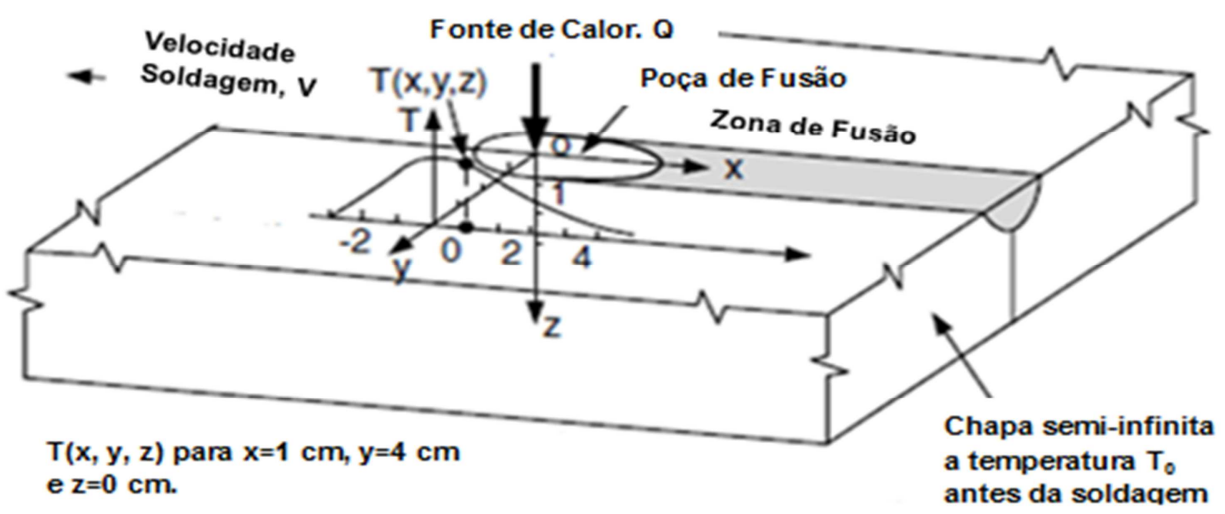

Figura 7 - Transferência de calor na condição 3D para uma peça semi-infinita. Adaptação [13]

A Equação 5 pode ser empregada para calcular a temperatura, relativa ao movimento da fonte de calor, em qualquer localização da peça $(x, y, z)$. Por exemplo, a $x=1 \mathrm{~cm}, y=4 \mathrm{~cm} \mathrm{e} z=0 \mathrm{~cm}$ conforme mostrado na Figura 7. As temperaturas ao longo de $y=4 \mathrm{~cm}$ também podem ser calculadas sendo possível a obtenção do perfil de temperatura ao longo desta coordenada [13].

A taxa de resfriamento de uma junta soldada pode ser calculada a partir da Equação de Rosenthal. Considerando-se que ao longo do eixo $x$ da peça $y=z=0$ e, portanto $R=x$, tem-se que:

$T-T_{0}=\frac{Q}{2 \pi k x}$

Portanto, o gradiente de temperatura é: 


$$
\left(\frac{\partial T}{\partial x}\right)_{t}=\frac{Q}{2 \pi x} \cdot \frac{-1}{x^{2}}=-2 \pi k \cdot \frac{\left(T-T_{0}\right)^{2}}{Q}
$$

Da Equação 7 e,

$\left(\frac{\partial x}{\partial t}\right)_{T}=V$

Tem-se que:

$\left(\frac{\partial T}{\partial t}\right)_{x}=\left(\frac{\partial T}{\partial x}\right)_{t}\left(\frac{\partial x}{\partial t}\right)_{T}=-2 \pi k V \frac{\left(T-T_{0}\right)^{2}}{Q}$

As soluções analíticas de Rosenthal apesar de possuírem muitas simplificações, são fáceis de usar e são muito apreciadas pelos profissionais da área de soldagem [13].

Diante do exposto até aqui nota-se que a condução do calor nas chapas grossas, além do fluxo bidirecional nas direções x e y deve ser considerado o fluxo na espessura da chapa. Em outras palavras, a condução do calor é maior na soldagem das chapas grossas e um rápido resfriamento pode levar a formação de fases frágeis, além de criar tensões internas residuais. Estas tensões residuais são de origem térmica e plástica, a distribuição não uniforme das temperaturas acarreta as dilatações e contrações não uniformes na região da junta soldada, podendo atingir níveis que levem a deformação plástica, ou elevadas restrições e a ocorrência de trincas.

\subsection{Microestrutura e tenacidade de uma junta soldada}

Uma junta soldada é, basicamente, dividida em duas regiões principais: o metal de solda (MS) e a zona afetada pelo calor (ZAC). Na Figura 8 são mostradas esquematicamente as regiões de uma junta soldada.

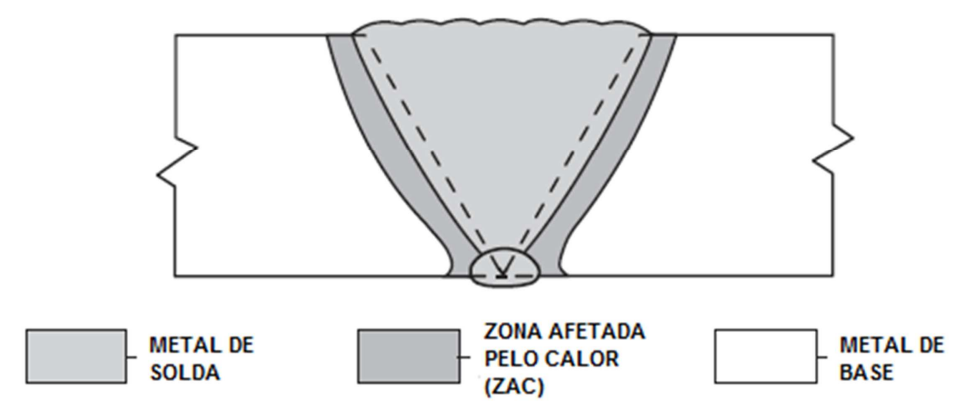

Figura 8 - Principais regiões de uma junta soldada. Adaptação [18] 
A microestrutura de uma junta soldada deve ser tal que apresente propriedades similares a do metal de base. Isso significa que o metal de solda e a zona afetada pelo calor devem ter propriedades que atendam, no mínimo, os limites inferiores das propriedades do metal de base [14,15].

O ciclo térmico de soldagem, depois da composição química do metal de base, é o item mais importante que influencia na microestrutura e propriedades do MS e da ZAC. O ciclo térmico depende do processo de soldagem empregado, do aporte de calor e da velocidade de resfriamento $[15,19]$. Assim é possível se obter uma grande variedade de microestruturas oriundas da decomposição da austenita. Um aço resfriado muito lentamente a partir do campo austenítico apresenta, à temperatura ambiente, uma ou mais fases: ferrita, perlita ou cementita dependendo de seu teor de carbono. Entretanto, se o resfriamento for muito rápido, outros constituintes metaestáveis aparecem, tais como, a bainita e a martensita. Estas transformações podem ocorrer por difusão (reconstrutivo), cisalhamento (displacivo) ou uma combinação dos dois mecanismos, conforme pode ser observado na Figura 9.

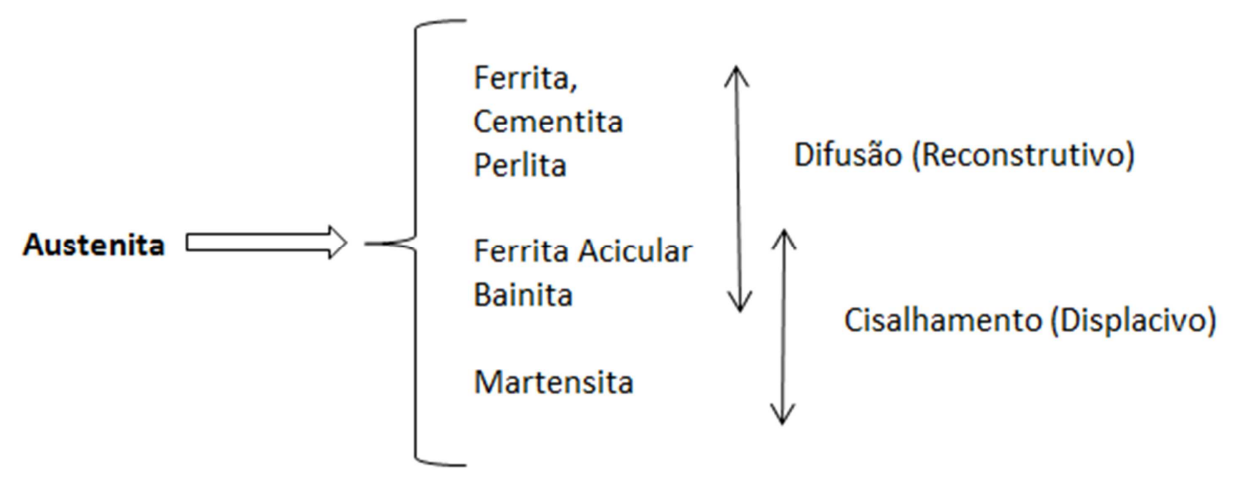

Figura 9 - Mecanismos operantes na decomposição da austenita. Adaptação [8]

\subsubsection{Transformação no metal de solda}

O diagrama de resfriamento contínuo (CCT) representado de forma esquemática pela Figura 10 mostra as principais microestruturas que podem ser obtidas a partir da transformação da austenita para metais de solda de aços baixocarbono. 


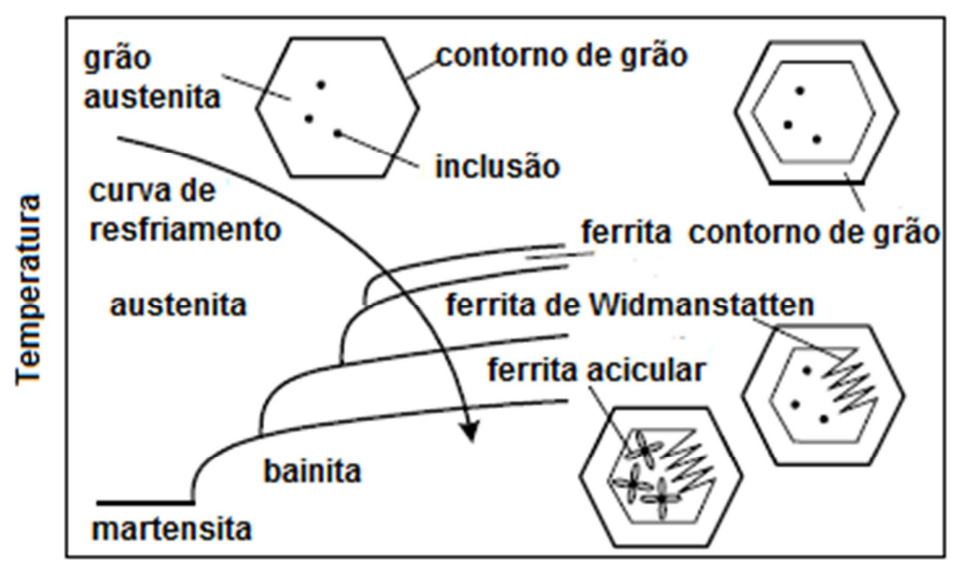

$\log$ Tempo

Figura 10 - Diagrama CCT para um metal de solda de aço baixo-carbono. Adaptação [13]

$\mathrm{Na}$ Figura 10 os hexágonos representam as seções transversais dos grãos colunares de austenita do metal de solda. À medida que a austenita é resfriada a partir de altas temperaturas, ferrita é nucleada nos contornos de grãos e cresce em direção ao interior do grão sendo chamada neste caso de ferrita alotriomórfica. Nas temperaturas mais baixas a mobilidade da frente de crescimento planar da ferrita de contorno de grão diminui e a ferrita de Widmanstatten ${ }^{1}$ se forma preferencialmente. Átomos substitucionais não se difundem durante o crescimento da ferrita de Widmanstatten. Nas temperaturas ainda mais baixas o crescimento da ferrita de Widmanstatten é dificultado em direção ao interior e é mais rápido se uma nova ferrita nuclear a frente da ferrita que cresce. Esta nova ferrita, que é a ferrita acicular, nucleia-se nas inclusões e tem uma morfologia de pequenos grãos agulhados orientados randomicamente. Na Figura 11 são mostradas microestruturas típicas de um metal de solda de aço baixo carbono.
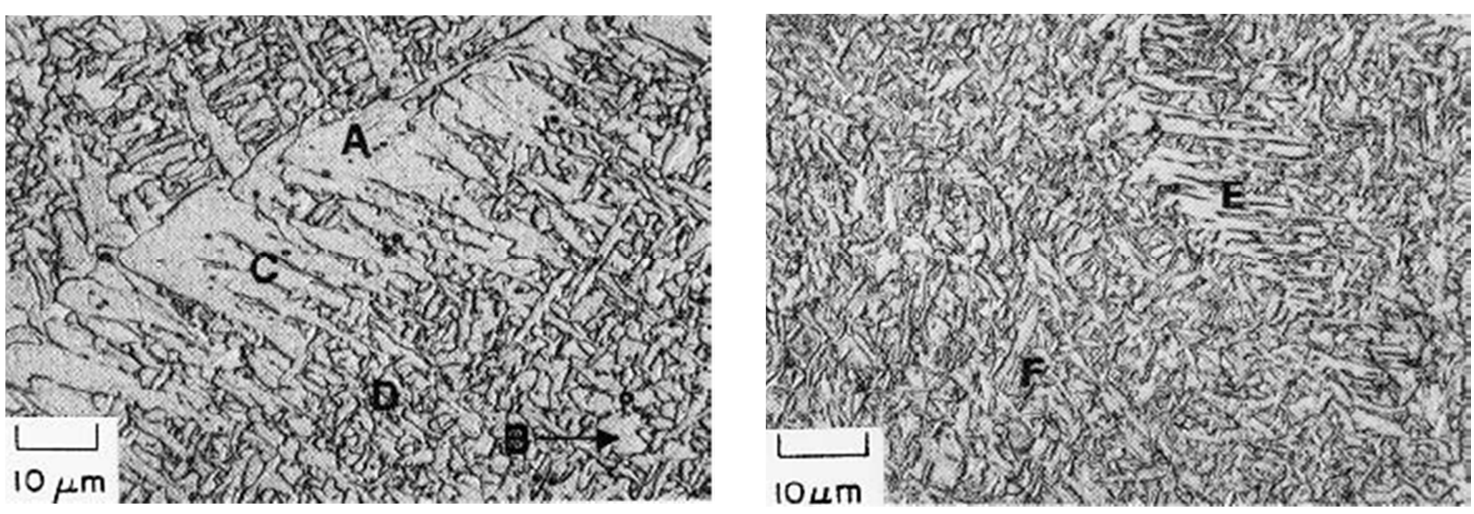

Figura 11 - Microestruturas típicas do metal de solda de aço baixo-carbono. A, ferrita de contorno de grão; B, ferrita poligonal; C, ferrita de Widmanstatten; D, ferrita acicular; E, bainita superior; F, bainita inferior. [13]

\footnotetext{
${ }^{1}$ Em homenagem ao cientista francês Alois de Widmanstätten.
} 
$\mathrm{Na}$ Figura 12 é mostrada a microestrutura de um metal de solda de aço baixo carbono contendo predominantemente ferrita acicular com um aumento maior que na Figura 11. As partículas escuras são inclusões.

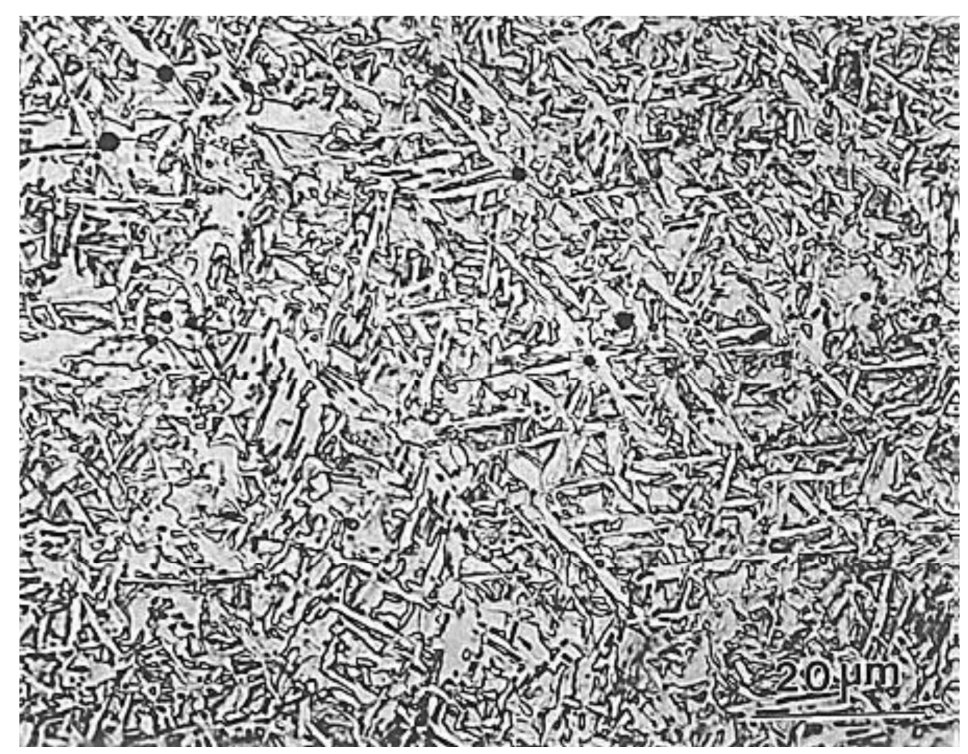

Figura 12 - Microestrutura constituída predominantemente por ferrita acicular. [13]

Segundo Bhadeshia, apud [13], a microestrutura de um metal de solda de aço baixo carbono depende basicamente de quatro fatores: composição química, a taxa de resfriamento de 800 a $500{ }^{\circ} \mathrm{C}\left(D_{\text {t8-5) }}\right.$ ), do conteúdo de oxigênio e do tamanho de grão austenítico. Na Figura 13 é mostrado esquematicamente o efeito destes fatores.

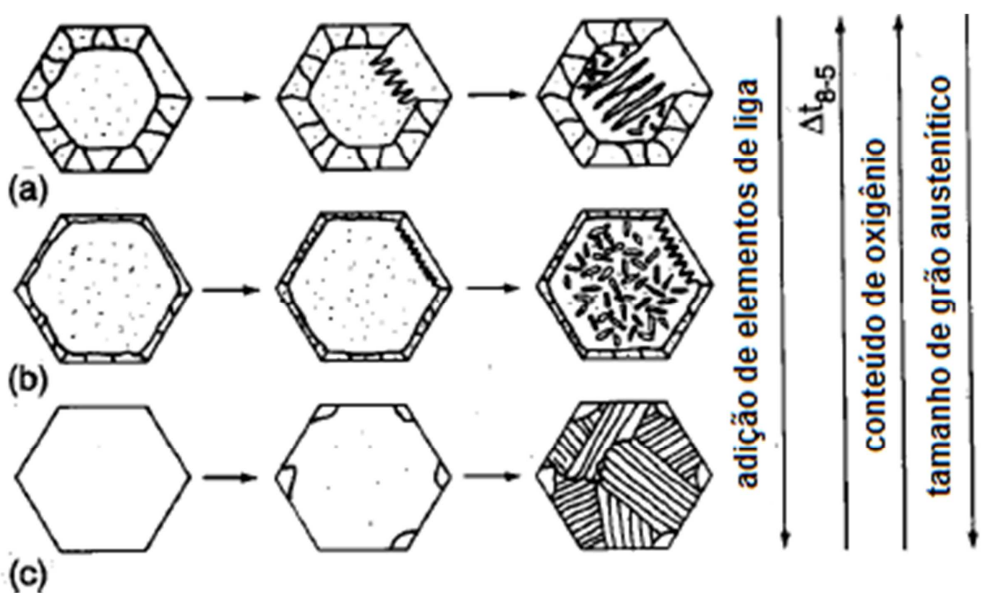

Figura 13 - llustração esquemática mostrando o efeito da adição de elementos de liga, tempo de resfriamento de 800 a $500{ }^{\circ}$, conteúdo de oxigêni o e tamanho do grão austenítico.

(a) microestrutura de ferrita primária de contorno de grão e de Widmanstatten, (b) ferrita acicular, (c) bainita. Adaptado de [13] 
Considerando o diagrama CCT mostrado na Figura 14 nota-se que uma diminuição da taxa de resfriamento da curva 1 para a curva 2 e para a curva 3 . Os produtos de transformação podem mudar de predominantemente bainita para ferrita: acicular, Windmanstatten e no contorno de grão, respectivamente.

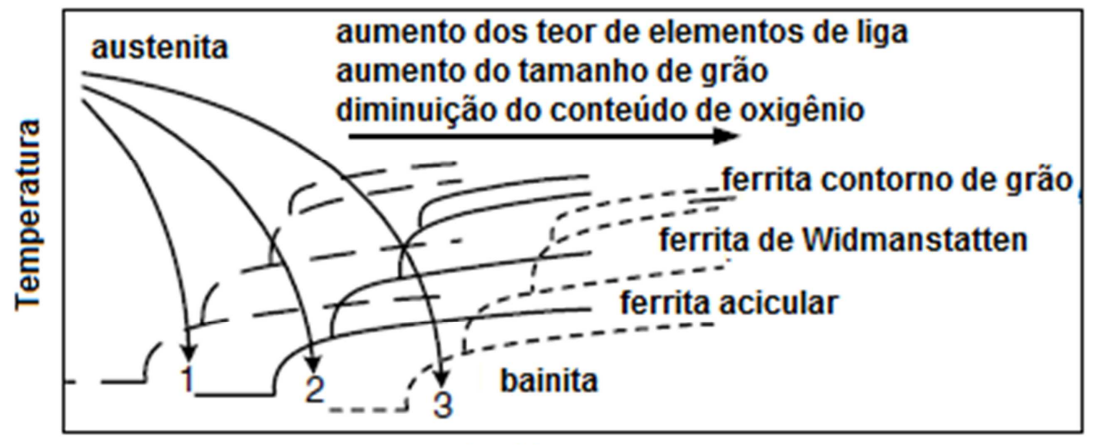

$\log$ Tempo

Figura 14 - Efeito dos elementos de liga, tamanho de grão e conteúdo de oxigênio nos diagramas CCT para metal de solda de aço baixo-carbono. Adaptado de [15]

A adição de elementos de liga e o aumento no tamanho do grão austenítico deslocam as curvas do diagrama para a direita e para temperaturas mais baixas [15].

A respeito do conteúdo de oxigênio no metal de solda, este promove dois efeitos principais: reduzir o crescimento do grão austenítico e favorecer, através da formação de inclusões, a nucleação da ferrita acicular [15].

\subsubsection{Tenacidade no metal de solda}

De todos os microconstituintes apresentados, é a ferrita acicular que tem grande efeito nas propriedades mecânicas do metal de solda. Este microconstituinte tem boa resistência à clivagem, desde que tenha baixo teor de carbono e não seja circundado por ilhas de martensita ou ferrita de segunda fase. Para melhorar as propriedades mecânicas, a quantidade ideal de ferrita acicular deve estar na faixa de 65 a $80 \%$ [12].

A ferrita acicular aumenta a tenacidade, pois a sua morfologia de grãos emaranhados bem como contorno de alto ângulo e elevada densidade de discordâncias não propicia caminhos preferenciais para a propagação de trincas exigindo grande dispêndio de energia para a propagação desta, na medida em que suas ripas obrigam a trinca a mudar de direção constantemente $[12,13]$. Deste modo a 
ferrita acicular é a microestrutura desejável para o metal de solda visto que esta a que aumenta consideravelmente a tenacidade.

Assim, vários estudos têm sido desenvolvidos, buscando aumentar a quantidade de ferrita acicular no MS como depositado, usando elementos de liga como Mn, Mo, Ti e B. A qualidade, quantidade, tipo e tamanho das inclusões determinam a formação da ferrita acicular sendo que duas inclusões não-metálicas, TiO e $\mathrm{MnAl}_{2} \mathrm{O}_{4}$ tem uma importante influência na formação da ferrita acicular [20]. O oxigênio desempenha um papel primordial na obtenção da desejada microestrutura acicular. Isto porque uma quantidade ideal de oxigênio que dispersado adequadamente em forma de óxidos é essencial para a nucleação intragranular da ferrita acicular. $\mathrm{Na}$ metalurgia dos aços, admite-se que o menor teor de oxigênio é o que confere as melhores propriedades de tenacidade no aço. Na metalurgia da soldagem, porém, sugere-se que oxigênio nos depósitos deva estar na faixa de $200-500$ ppm [20]. O oxigênio é fornecido ao metal de solda principalmente através dos consumíveis, ou seja, os eletrodos, fluxos e gases de proteção. Em geral, um metal de solda depositado pelo processo FCAW com $100 \%$ de $\mathrm{CO}_{2}$ possui um teor na faixa de 450 a 600 ppm de $\mathrm{O}_{2}[13,20]$.

Outro aspecto importante que deve ser destacado é a influencia do processo de soldagem. Em geral o processo eletrodo revestido (SMAW) produz soldas com maior tenacidade que o arame tubular (FCAW). Evans [21] em seu extenso estudo obteve pelo processo SMAW soldas do tipo C-Mn com composição química semelhante ao metal depositado pelo E71T-1C valores médios de 200J. Farneze [22] em seu estudo que comparava a tenacidade dos metais de solda produzidos pelo processo SMAW e FCAW concluiu que o metal de solda obtido pelo processo arame tubular tende a produzir uma menor tenacidade ao impacto, quando comparado ao obtido pelo processo eletrodo revestido, sendo que esta diferença pode ser atribuída à ocorrência de uma microestrutura mais grosseira, maior percentual de região colunar no metal de solda do arame tubular resultante do menor número de passes.

Nota-se também que, para o processo GMAW, a tenacidade do metal de solda na região da raiz é menor quando comparada a região dos passes de acabamento. Na Figura 15 é apresentado um gráfico comparativo das tenacidades na região da raiz e do acabamento para diversos metais de solda.

Os menores valores de tenacidade encontrados na raiz podem ser decorrentes da diluição do metal de solda com o metal de base, mas principalmente pela fragilização da raiz provocada pela combinação dos efeitos de deformação plástica e aquecimento a $200^{\circ} \mathrm{C}[15]$. 


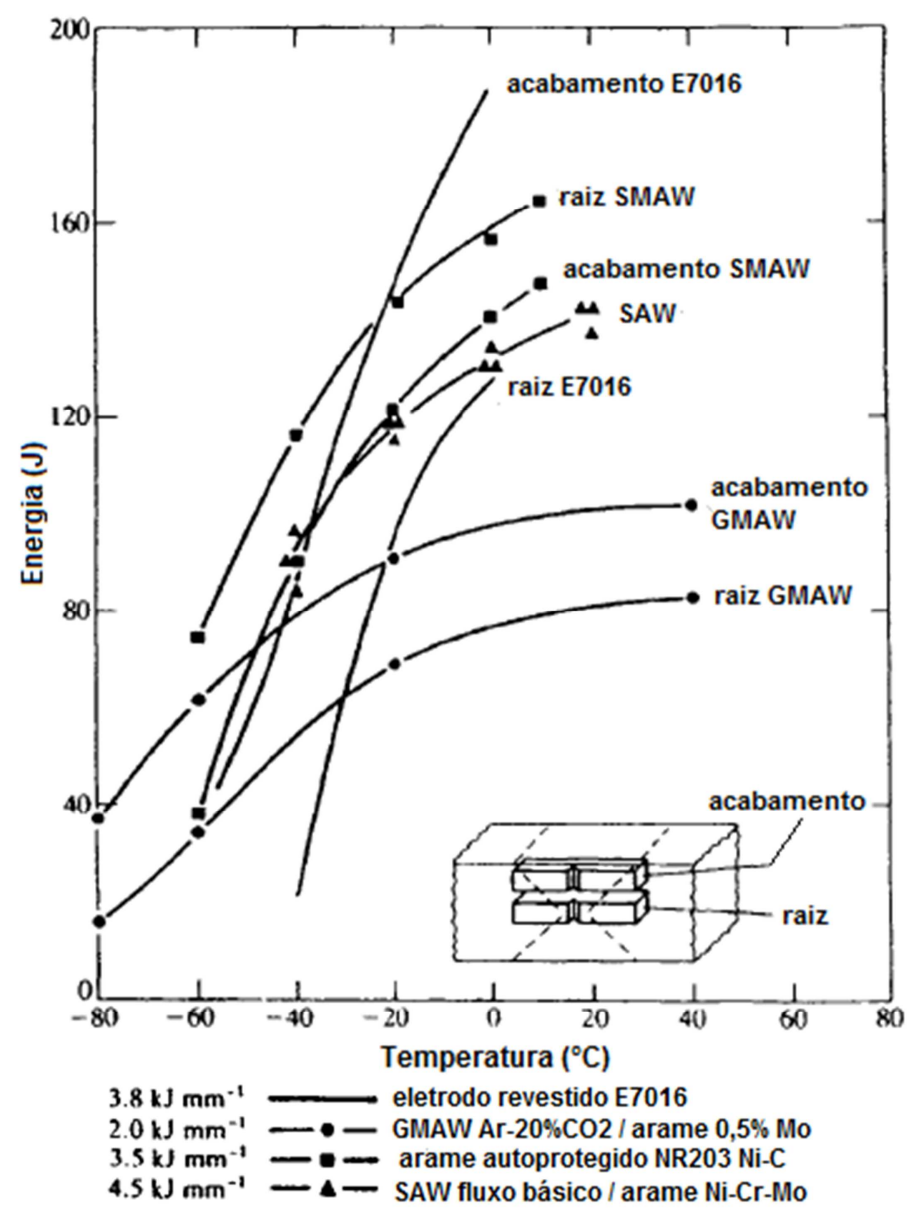

Figura 15 - Curvas de transição - Charpy para diversos metais de solda. Adaptado de [15]

A espessura da chapa também exerce influência na tenacidade do metal de solda. Pela análise do gráfico mostrado na Figura 16, nota-se uma redução nos valores a partir da espessura de $40 \mathrm{~mm}$, destacando mais uma vez a diferença entre os valores de tenacidade na raiz e no acabamento.

\subsubsection{Transformação na Zona Afetada pelo Calor (ZAC)}

Enquanto, a microestrutura do metal de solda depende diretamente das condições de solidificação e das taxas de resfriamento na Zona Afetada pelo Calor (ZAC) é o ciclo térmico completo o fator determinante na formação da microestrutura. [15]. Do ponto de vista metalúrgico, a ZAC dos aços pode ser divida em três zonas: supercrítica, intercrítica e subcrítica. Na Figura 17 são mostradas, de forma esquemática, as diversas regiões da ZAC. 


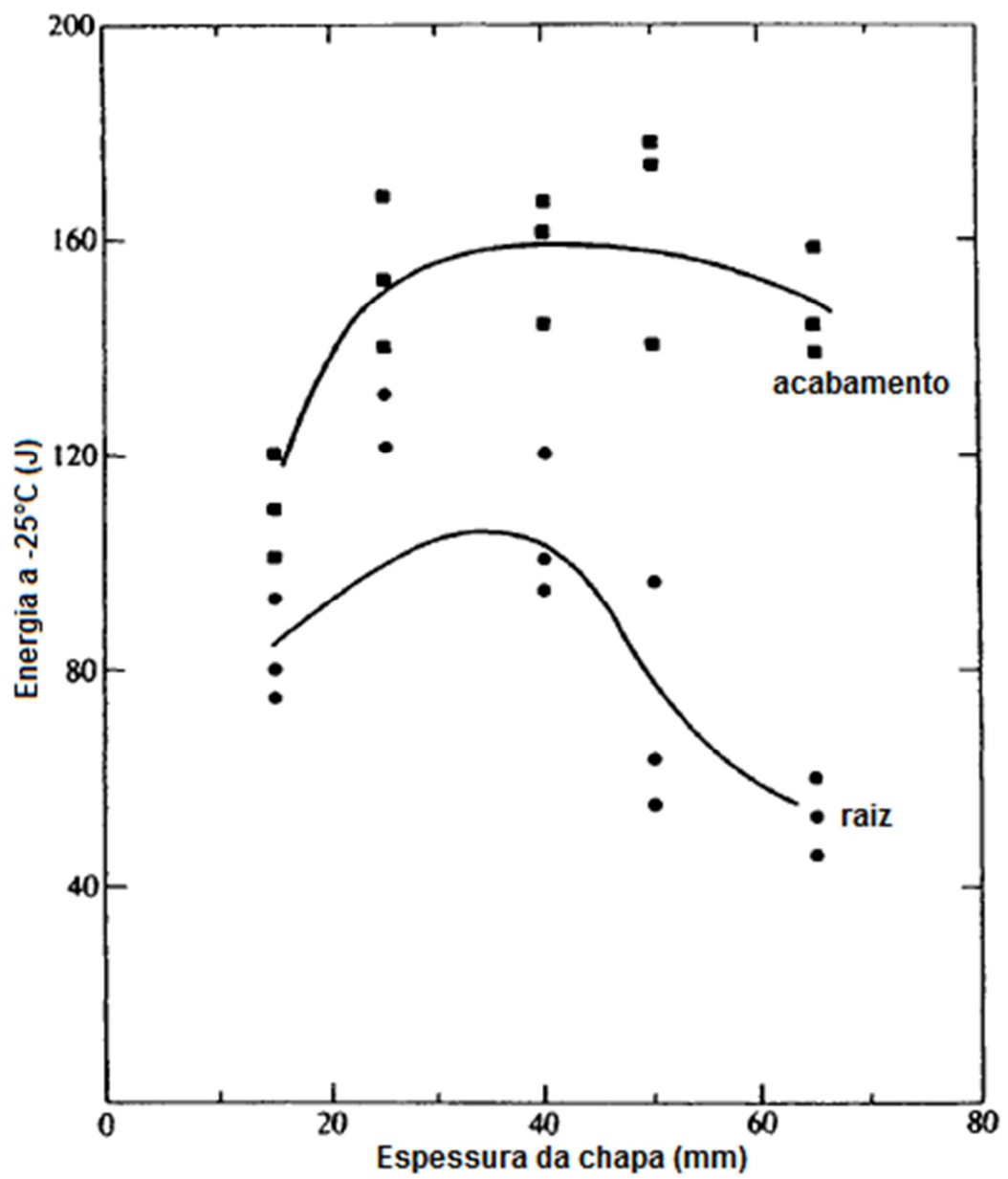

Figura 16 - Variação da tenacidade Charpy a -25 $\mathrm{C}$ e m juntas com chanfro duplo "V" soldadas na posição vertical com eletrodo E7016 e aporte de calor de $3,8 \mathrm{kJmm}^{-1}$. Adaptado de [15]

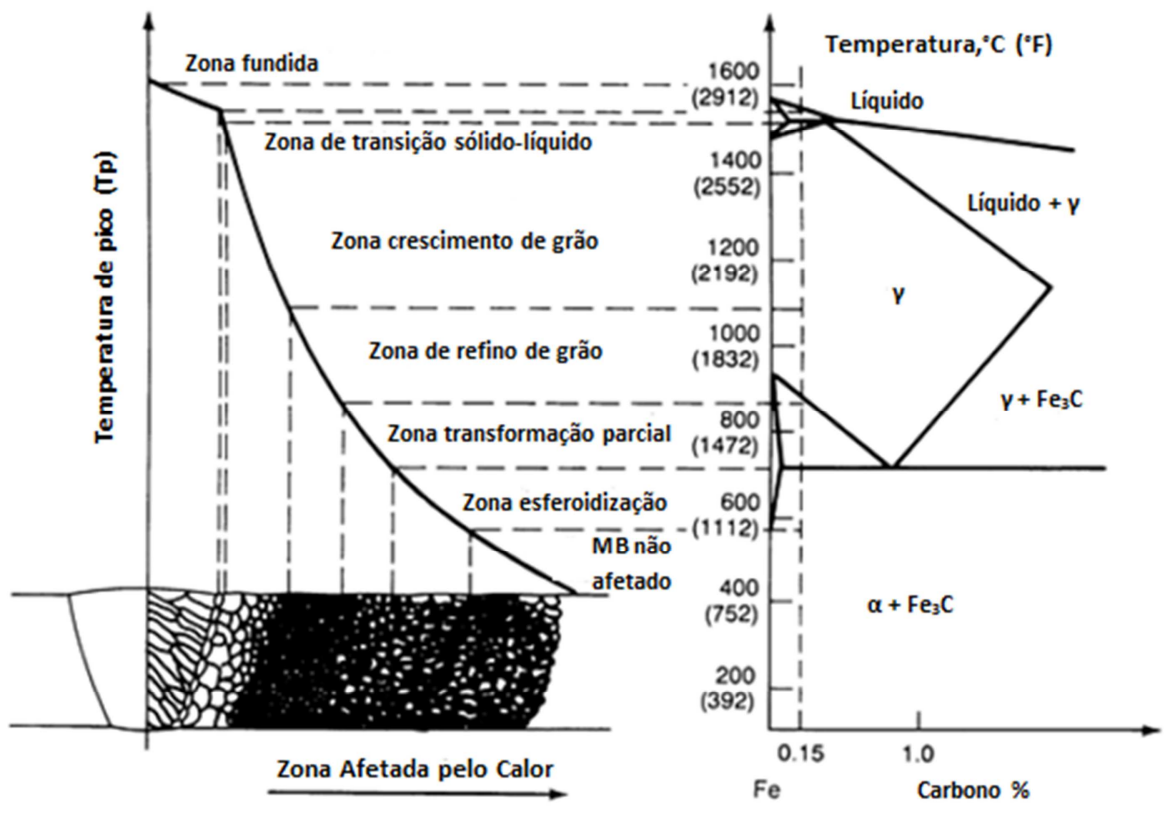

Figura 17 - Esquema mostrando as várias zonas que podem ser formadas na ZAC de um açocarbono contendo $0,15 \%$ C. Adaptado de [23] 
A região supercrítica, por sua vez pode ser dividida em duas partes: a região de crescimento de grão e a zona de refino de grão. O crescimento de grão ocorre quando a temperatura do ciclo térmico excede a temperatura de crescimento de grão. Abaixo desta temperatura, o ciclo térmico produz, em geral, um grão de tamanho inferior ao do metal de base. A microestrutura da zona de crescimento de grão é dominada por dois fatores: o tamanho de grão da austenita e as transformações estruturais no interior do grão. Para qualquer aço, quanto maior o aporte de calor, maior é o tempo acima da temperatura de crescimento do grão e assim maior é o tamanho do grão. O tipo da microestrutura na região de crescimento de grão depende do teor de carbono e dos elementos de liga presentes no metal de base, além do tamanho de grão e da taxa de resfriamento. Nos aços baixo carbono, a ferrita proeutetóide forma-se primeiro nos contornos dos grãos austeníticos e dentro do grão desenvolve-se a microestrutura de ferrita-perlita e ou ferrita-bainita. Com o incremento da taxa de resfriamento ou com o aumento do teor de carbono e elementos de liga, a ferrita proeutetóide desaparece e os grãos de austenita transformam-se completamente em microestruturas aciculares: bainita superior, bainita inferior ou martensita ou ainda uma mistura destes microconstituintes. À medida que a distância aumenta a partir da linha de centro, tanto o pico de temperatura quanto a taxa de resfriamento diminuem. Assim, a zona de refino do grão pode apresentar uma microestrutura similar aquela dos aços normalizados.

Na região intercrítica, que é relativamente estreita, pode ocorrer transformação parcial. No caso de um aço que apresenta uma microestrutura de ferrita-perlita antes da soldagem, as ilhas de perlita, que são eutetóides quanto ao conteúdo de carbono, transformam-se em austenita no aquecimento e em martensita ou bainita no resfriamento. Na condição "como soldado" a região pode consistir de grãos endurecidos sobre uma matriz ferrítica não transformada [15].

$\mathrm{Na}$ região subcrítica não se observa normalmente alterações significativas na microestrutura, exceto em uma pequena faixa onde pode ocorrer uma esferoidização geralmente muito difícil de ser detectada. [15].

Na soldagem multipasse, as ZAC's formadas no metal de solda previamente depositado são retransformadas: grãos grosseiros podem ser refinados e vice-versa.

O efeito da soldagem multipasse é geralmente benéfico reduzindo a dureza e aumentado a tenacidade. 


\subsubsection{Constituinte M-A e a sua influência na tenacidade de juntas soldadas}

As altas taxas de resfriamento encontradas na soldagem podem favorecer a formação das chamadas microfases onde o destaque é para o constituinte martensitaaustenita (M-A) que é essencialmente uma mistura de martensita não-revenida incorporada a austenita retida. O processo de formação do constituinte M-A inicia-se no resfriamento a partir da transformação austenítica onde há a formação de ferrita de Widmanstatten ou de bainita a temperaturas maiores que aquelas onde a martensita pode ser formada $\left(M_{s}\right)$. Assim a austenita residual é enriquecida de carbono $^{2}$ reduzindo a temperatura de transformação inicial da martensita $\left(M_{S}{ }^{r}\right)$. Se esta temperatura for maior que a temperatura ambiente, parte da austenita se transforma em martensita e parte pode permanecer na forma de austenita retida formando assim o constituinte M-A [24].

A princípio o constituinte $\mathrm{M}-\mathrm{A}$ é formado preferencialmente nas diversas regiões da zona afetada pelo calor na soldagem multipasse, porém também pode ser formado no metal de solda de acordo com estudos realizados por Garland e Kirkwood [25]. Outros pesquisadores também relataram em seus trabalhos a presença do constituinte $M-A$ no metal de solda [26,27]. O constituinte $M-A$ pode reduzir a tenacidade do metal de solda dependendo do tipo, tamanho e localização. Quando a M-A está presente na forma de blocos constituídos por martensita associados com carbonetos bainíticos em ilhas dispersas aleatoriamente, o efeito geralmente é deletério, pois tais microfases facilitam a nucleação de trincas por clivagem. Se tais microfases aparecem na forma de bandas de segregação, como nas soldas com alto conteúdo de carbono e manganês, a situação pode ser ainda pior uma vez que as trincas por clivagem podem ser capazes de tanto nuclearem como se propagarem com facilidade [26]. Por outro lado, caso as partículas sejam finas e uniformemente distribuídas pode haver um aumento na tenacidade [27].

\subsection{Trinca a frio induzida pelo hidrogênio}

É rara a presença intencional de hidrogênio na soldagem, exceto quando se utiliza uma mistura de gás inerte contendo hidrogênio para servir de gás de proteção na soldagem TIG (GTAW) ou MIG (GMAW) de aços inoxidáveis austeníticos, a fim de se aumentar o aporte de calor e deste modo permitir uma maior velocidade de

\footnotetext{
${ }^{2}$ Este enriquecimento de carbono é provocado pelo próprio crescimento da ferrita.
} 
soldagem. $O$ valor da solubilidade do hidrogênio na austenita permite o emprego de misturas gasosas contendo este gás, porém o mesmo não acontece quando se trata de microestruturas ferríticas onde a solubilidade deste gás é muito pequena.

Exceto no caso acima mencionado, o hidrogênio em geral penetra no metal de solda por meio da umidade absorvida pelos consumíveis de soldagem, sendo o hidrogênio ionizado em $\mathrm{H}^{+}$na região do arco elétrico.

O hidrogênio monoatômico é solúvel no aço líquido e sua solubilidade diminui à medida que a temperatura decresce, não somente quando ocorre a passagem de líquido para sólido, mas também durante o resfriamento da fase sólida. A curva de Sieverts esquematizada na Figura 18 mostra a solubilidade do hidrogênio nas diversas fases do ferro em função da temperatura. Nota-se pela análise desta curva que a solubilidade do hidrogênio no ferro alfa a temperaturas próximas da ambiente é mínima.

Devido à rápida solidificação da poça de fusão, muitas vezes o hidrogênio é aprisionado no metal sólido, porém o mesmo difunde-se com facilidade pela ferrita e tende a escapar para a atmosfera em relação ao tempo conforme mostra a Figura 18, até um limite correspondente ao chamado "hidrogênio difusível". Nota-se também pela análise do gráfico que tal fenômeno é favorecido pelo aumento da temperatura.

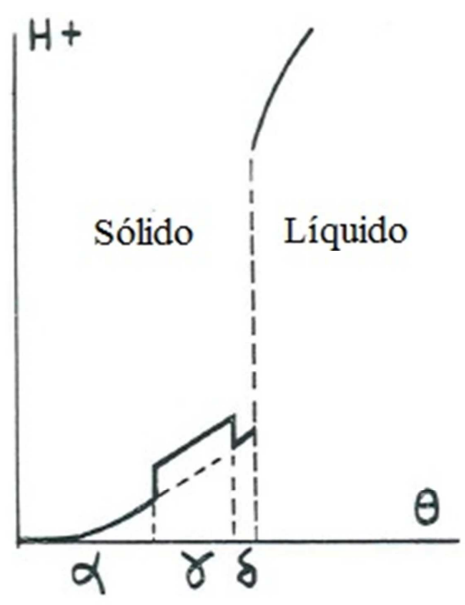

(a)

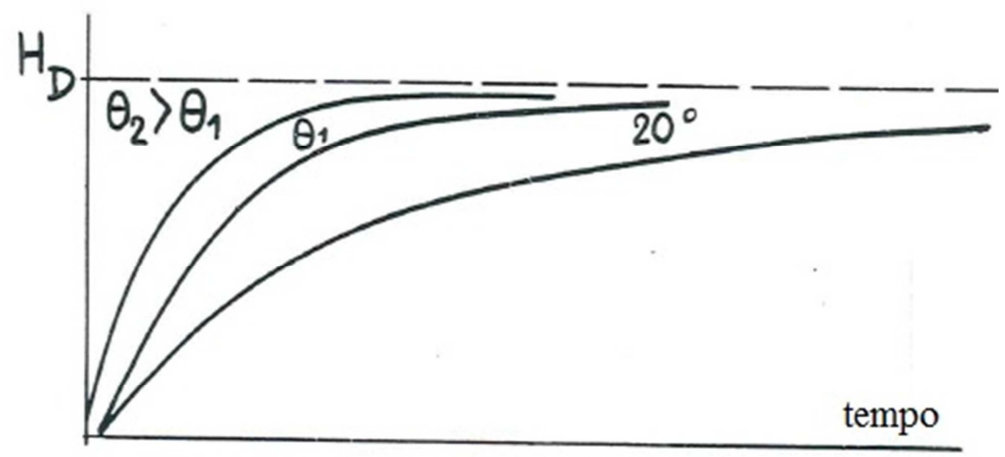

(b)

Figura 18 - (a) Solubilidade do hidrogênio no ferro com base na temperatura (de acordo com Sieverts). (b) Evolução do hidrogênio com base na temperatura e tempo a partir de uma amostra de metal depositado por soldagem $\left(H_{D}=\right.$ hidrogênio difusível). Adaptado de [16]. Desenho de próprio punho do Granjon.

Com foi mencionado, o hidrogênio em solução supersaturada tende a sair do metal de solda e escapar para a atmosfera, porém ele pode se deslocar em direção a alguma fase sólida como a zona de fusão e a zona afetada pelo calor. Essa difusão, 
que começa no início do resfriamento e continua posteriormente, é influenciada por um lado pelo conteúdo inicial de hidrogênio no término do resfriamento e por outro pela diferença do coeficiente de difusão entre a austenita e a ferrita, pois o hidrogênio difunde-se mais facilmente nesta última do que na primeira. Por fim, as consequências da presença de hidrogênio estão associadas com a fragilização da ferrita ou martensita, em razão da presença de íons $\mathrm{H}^{+}$na estrutura cristalina destes dois microconstituintes.

Um modelo de fragilização por hidrogênio durante a soldagem, considerandose o metal de solda com menor temperabilidade que o metal de base, foi proposto por Granjon [14] e pode ser visto esquematicamente na Figura 19.

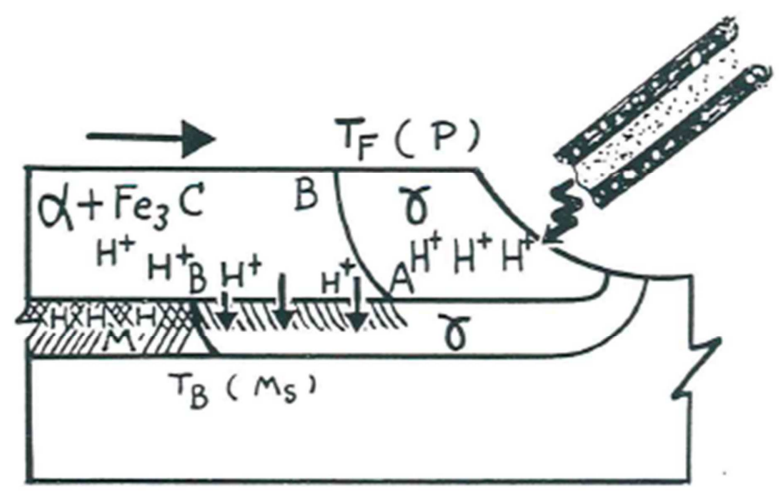

Figura 19 - Mecanismo de fragilização por hidrogênio durante a soldagem. Desenho de próprio punho do Granjon [16]

O hidrogênio é introduzido pela atmosfera do arco para a poça de fusão. Ao se solidificar o aço transforma-se em austenita e perde um pouco de hidrogênio para a atmosfera. Durante o resfriamento quando ocorre a decomposição da austenita em ferrita+cementita cai a solubilidade do hidrogênio e este difunde-se para a região austenitizada do metal de base. No resfriamento, essa região com maior teor de hidrogênio pode temperar, formando a martensita. Consegue-se desta forma ter hidrogênio associado a uma microestrutura frágil $[12,13,15]$. Na Figura 20 é mostrado um exemplo típico de trinca induzido por hidrogênio.

Os aços de alta resistência são muito susceptíveis as trincas a frio induzida por hidrogênio cujo aparecimento pode não ser imediato, razão pela qual se recomenda a inspeção com ensaio não destrutivo 48 horas após a execução da soldagem [5,14]. A trinca a frio induzida por hidrogênio ocorre quando se tem uma ou mais das seguintes condições: presença de hidrogênio, tensão residual de tração, microestrutura susceptível e baixa temperatura [14,28,29,30]. 


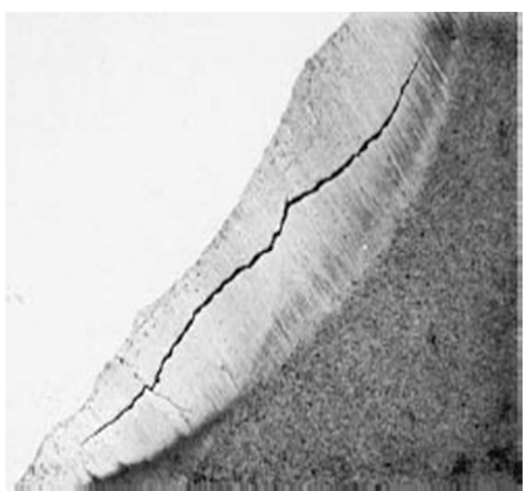

(a)

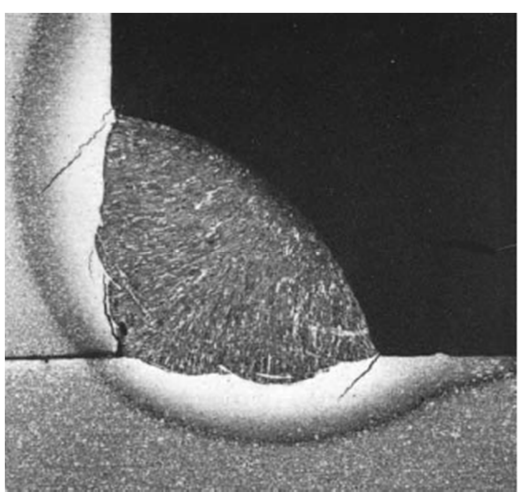

(b)

Figura 20 - Trincas a frio induzidas por hidrogênio. Em (a) tem-se um metal de adição de maior temperabilidade do que o metal de base e a trinca ocorreu na solda. Em (b), um metal de adição de menor temperabilidade do que o metal de base e as trincas ocorreram na ZAC. [13]

Assim, a norma AWS D1.1 em seu Anexo I [5], estabelece dois métodos que são usados para estimar as condições adequadas para se evitar a formação deste tipo de trinca:

(1) Controle de dureza na zona afetada pelo calor (ZAC)

(2) Controle do hidrogênio.

Os detalhes deste método estão descritos na norma em questão.

Segundo a norma EN DIN 1011-2, a medida mais efetiva de se evitar a trinca a frio é reduzindo o teor de hidrogênio difusível dos consumíveis [31]

\subsection{Testes de soldabilidade}

De um modo geral, apenas com a qualificação de um procedimento de soldagem torna-se difícil se determinar as condições seguras para a execução da soldagem de modo a se evitar o risco da formação de trincas a frio induzidas por hidrogênio. Para contornar essa situação a norma ISO 17642-2 [32] e a ASM [23] por meio de suas publicações incentivam o emprego dos testes de soldabilidade.

Os testes de soldabilidade desenvolvidos para avaliar a sensibilidade ao trincamento a frio de juntas soldadas são classificados geralmente, como diretos e indiretos. Dentre os diretos destacam-se pela grande aplicação os testes: CTS (Controlled Thermal Severity), Tekken (Y-Groove Restraint Test), o de restrição LEHIGH e o G-BOP. Estes permitem uma rápida avaliação da junta total (metal de solda e zona afetada pelo calor) pela contagem da quantidade de trincas para cada peça de testes, mas dependem do nível de restrição imposto e da forma do chanfro e do cordão de solda $[23,33,34]$. 
Na peça de testes CTS duas soldas de teste (filete) são aplicadas em duas chapas unidas por soldas de ancoramento. As circunstâncias (índice de hidrogênio no metal de solda, temperatura de pré-aquecimento, aporte de calor), sobre a trinca não propagada são estabelecidas. Neste tipo de teste existe uma condição onde o escoamento do calor dá-se em duas dimensões e outro em três dimensões. Caso ocorra a formação de trincas, a extensão destas é determinada por de exame metalográfico. Na Figura 21 está ilustrado esquematicamente o teste CTS.
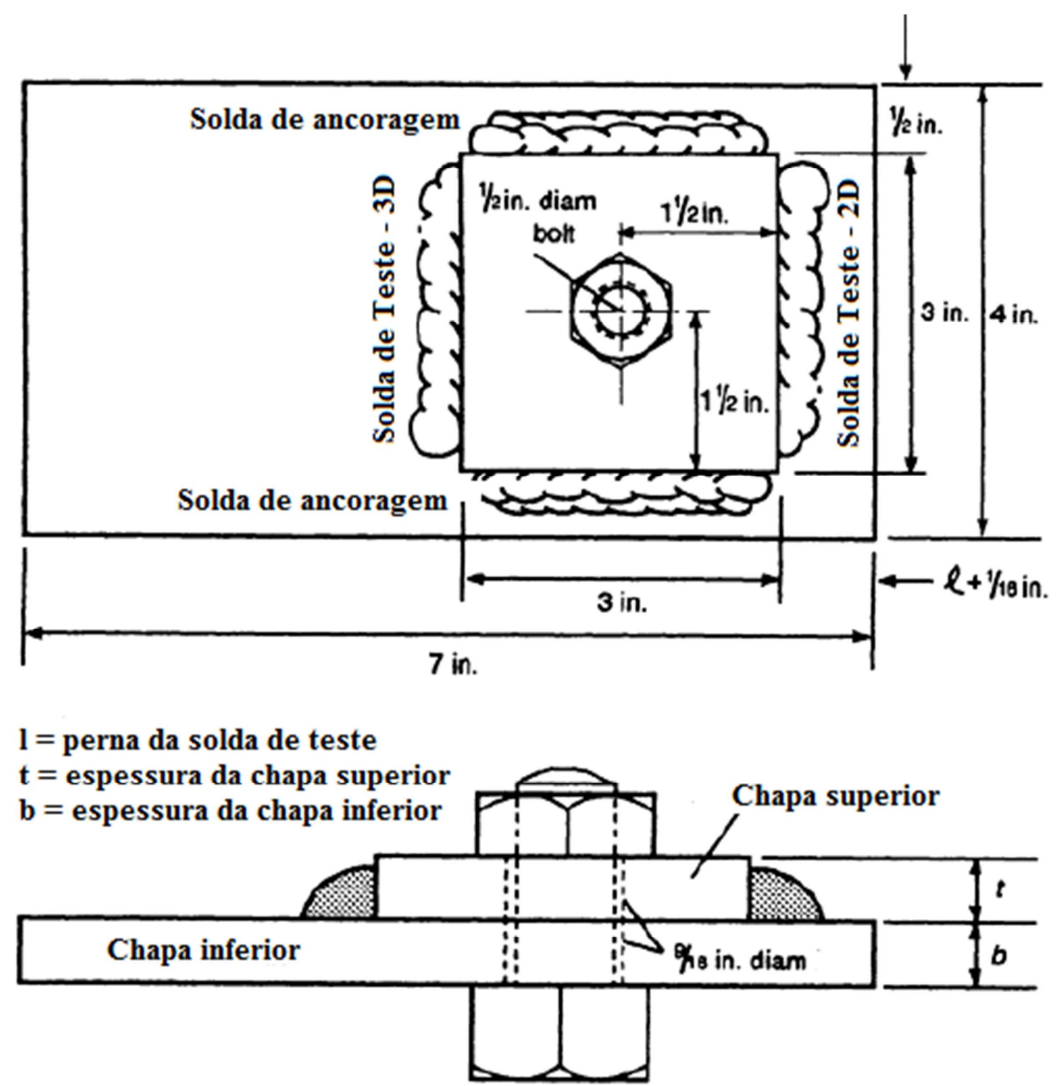

Figura 21 - Dimensões principais da peça de testes CTS - Controlled Thermal Severity Test. $[23,34]$

O teste CTS baseia-se nas taxas de resfriamento impostas pelas espessuras das chapas e pela diferença das taxas de resfriamento entre as soldas $2 D$ e 3D. É indicado especialmente para a avaliação da susceptibilidade ao trincamento a frio de aços temperáveis $[23,33,34]$.

\subsection{Tratamento térmico de alívio de tensões após a soldagem}

De um modo geral as operações de soldagem produzem consideráveis tensões residuais que podem ser inaceitáveis dependendo do tipo de aplicação do componente 
ou da estrutura. Por este motivo, em certos casos torna-se necessário o emprego do tratamento térmico de alívio de tensões após soldagem (TTAT). Nas estruturas metálicas o TTAT é aplicado em duas situações: redução do nível de tensões internas dos materiais ou para tentar manter a estabilidade dimensional [5].

As tensões residuais podem ser reduzidas através da deformação plástica [35]. Isto significa que a tensão de escoamento do material deve ser reduzida abaixo do valor das tensões residuais. Os processos de TTAT consistem em aquecer, após a soldagem, um componente ou estrutura a uma determinada temperatura por um determinado tempo. As operações de tratamento térmico compreendem basicamente três etapas:

1. Aquecer até a temperatura de tratamento (temperatura de patamar);

2. Manter por um determinado intervalo de tempo nesta temperatura (tempo de patamar);

3. Resfriar a uma taxa que evite gradientes de temperatura excessivos em diferentes pontos da peça que está sendo tratada, podendo posteriormente causar apreciáveis níveis de tensões residuais.

A norma AWS D1.1 [5] estabelece que a taxa de aquecimento para se atingir a temperatura de patamar não deve exceder o valor de $204^{\circ} \mathrm{C} / \mathrm{h}$ dividido pela espessura máxima do membro de maior espessura, em polegadas, mas em nenhum caso superior a $204{ }^{\circ} \mathrm{C} / \mathrm{h}$. Alcançada a temperatura máxima de patamar de $600^{\circ} \mathrm{C}$ para aços temperados e revenidos ou de $650^{\circ} \mathrm{C}$ para outros aços, a peça ou estrutura devem permanecer nesta temperatura por um tempo mínimo de patamar que é definido pela Tabela 5.2 da norma. O resfriamento deve ocorrer respeitando-se uma taxa máxima de $260^{\circ} \mathrm{C} / \mathrm{h}$ dividida pela espessura máxima do membro de maior espessura, mas em nenhum caso superior a $260^{\circ} \mathrm{C} / \mathrm{h}$.

Observa-se, que a execução TTAT para reduzir as tensões residuais pode afetar diretamente nas propriedades mecânicas finais. A fim de caracterizar o efeito combinado do tempo e da temperatura nas propriedades mecânicas foi proposto por Hollomon-Jaffe $[36,37]$ um parâmetro que pode ser expresso pelas equações 10 e 11:

$$
H=T \frac{(C+\log \tau)}{1000}
$$


Sendo:

$\tau=t+\frac{T}{\left[2,3 K_{1}\left(20-\log K_{1}\right)\right]}+\frac{T}{\left[2,3 K_{2}\left(20-\log K_{2}\right)\right]}$

Onde $\mathrm{H}$ é o parâmetro de Hollomon-Jaffe, C é uma constante, $\mathrm{T}$ é a temperatura de patamar em $\mathrm{K}, \mathrm{t}$ é o tempo de patamar em $\mathrm{h}, \mathrm{K}_{1}$ é a taxa de aquecimento em $\mathrm{K} / \mathrm{h}$ e $\mathrm{K}_{2}$ é a taxa de resfriamento em $\mathrm{K} / \mathrm{h}$. Na prática adota-se um valor de $\mathrm{C}=20$ para aços $\mathrm{C}-\mathrm{Mn}$ e aços baixa-liga [36,37].

O parâmetro $\mathrm{H}$ possibilita combinar diversos ciclos de TTAT em um único valor e também estimar a redução média nos valores de limites de resistência e de escoamento, conforme pode ser observado na Figura 22.

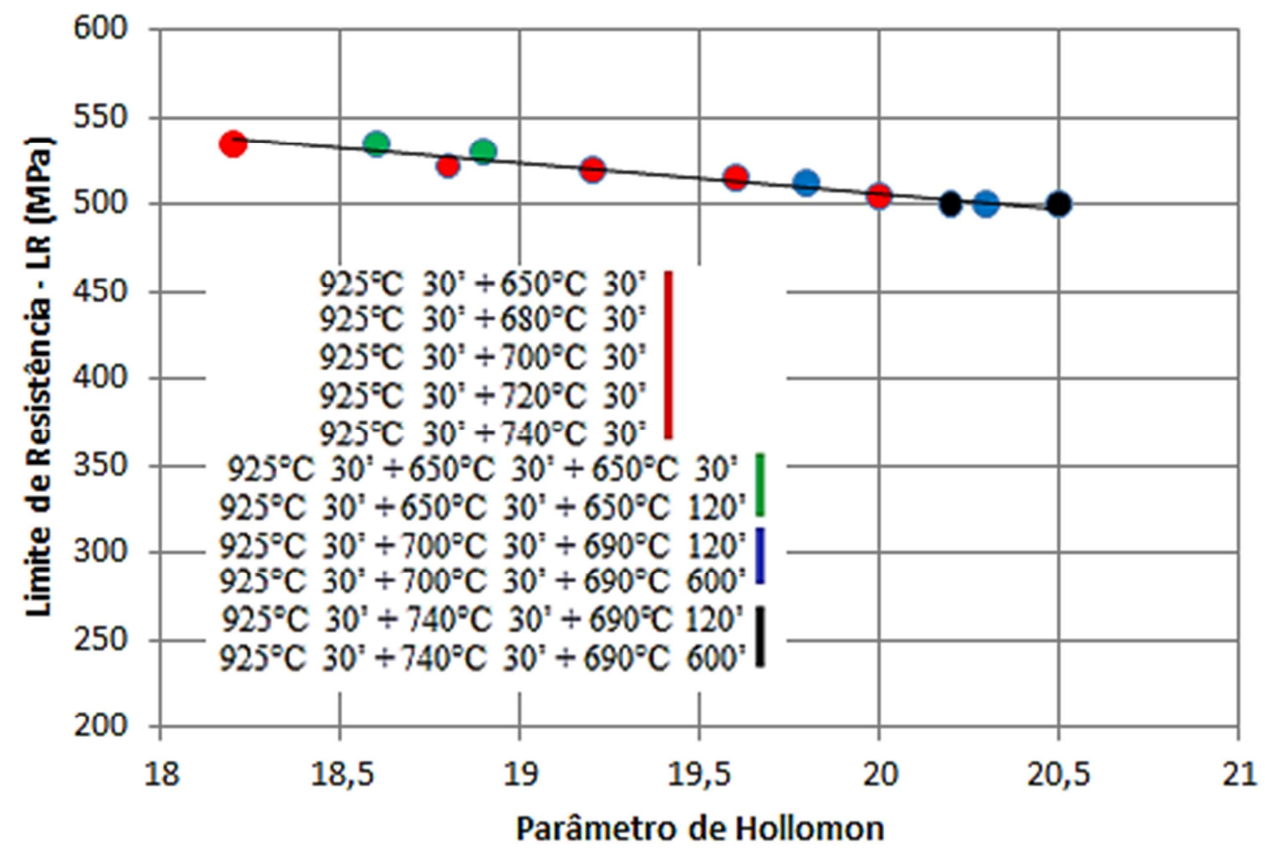

Figura 22- Variação do LR em função do parâmetro H para aço ASTM A387-11-2, $\mathrm{N}+\mathrm{T}$, em várias condições de TTAT. Adaptado de [38]

Na Figura 22 são mostrados que diferentes tratamentos térmicos com o mesmo parâmetro $\mathrm{H}$ produzem efeito similar no material e também que, quanto maior $\mathrm{o}$ número $\mathrm{H}$, maiores são as reduções nos limites de resistência e de escoamento e aumento na temperatura de transição dúctil-frágil [36,37].

O parâmetro de Hollomon pode ser bastante útil quando é considerado apenas o metal de base (MB), porém existem considerações metalúrgicas que devem ser feitas quando são abordadas as regiões da zona afetada pelo calor (ZAC) e o metal de solda (MS) ou zona fundida (ZF) de uma junta soldada. Segundo a norma AWS D1.1 em certos tipos de aços temperados e revenidos não é recomendado o tratamento 
térmico de alívio de tensões após soldagem. Nesta categoria está incluído o aço ASTM A514. Entretanto, o alívio de tensões pode ser necessário para certas aplicações conforme discutido anteriormente. Porém, segundo Swift \& Rogers [39] pode ocorrer uma fragilização após o TTAT. Segundo estes autores, aços temperados e revenidos são mais susceptíveis a essa fragilização do que os aços com microestrutura ferritico-bainítica ou ferritico-perlitica.

Com relação à temperatura de tratamento, a situação pode se tornar complicada quando diferentes materiais são unidos por soldagem, constituindo uma junta dissimilar que depois é submetida ao TTAT. Em algumas situações há a necessidade de se soldar um aço-baixa liga com um aço carbono estrutural como, por exemplo, o ASTM A36 com o ASTM A514 e depois submeter esta junta ao TTAT. Neste caso torna-se necessário avaliar os efeitos do tratamento nas propriedades mecânicas, a temperatura de patamar a ser empregada considerando-se a norma utilizada na qualificação do procedimento de soldagem e a temperatura de revenimento do A514 além dos possíveis efeitos de fragilização causados pelo TTAT na ZAC e na ZF.

\subsection{Corte térmico de chapas}

Para metais oxidáveis, de um modo geral, o processo de oxicorte (OFC) é a primeira escolha tanto na indústria quanto nos canteiros de obras. Em comparação com outros processos de corte, o oxicorte é o que oferece menor custo inicial do equipamento, alta produtividade e versatilidade e requer pouco treinamento de operação.

O processo de oxicorte está baseado em reações químicas onde o metal é préaquecido por uma chama proveniente da mistura combustível ${ }^{3}$ até a sua temperatura de ignição ${ }^{4}$ onde então esse metal é removido pela rápida oxidação promovida por um jato de oxigênio puro. Esta reação de oxidação gera grandes quantidades de calor que suportam a reação continuamente até o final do corte [40,41]. As equações balanceadas para estas reações estão descritas abaixo:

$$
\begin{aligned}
& \mathrm{Fe}+\mathrm{O} \rightarrow \mathrm{FeO}+\text { calor }(267 \mathrm{~kJ}), \text { primeira reação } \\
& 3 \mathrm{Fe}+2 \mathrm{O}_{2} \rightarrow \mathrm{Fe}_{3} \mathrm{O}_{4}+\text { calor }(1120 \mathrm{~kJ}), \text { segunda reação } \\
& 2 \mathrm{Fe}+1.5 \mathrm{O}_{2} \rightarrow \mathrm{Fe}_{2} \mathrm{O}_{3}+\text { calor }(825 \mathrm{~kJ}), \text { terceira reação }
\end{aligned}
$$

\footnotetext{
${ }^{3}$ Acetileno e oxigênio, podendo o primeiro ser substituído por gás natural, propano, MAPP ou propileno conforme conveniência.

${ }^{4} \mathrm{~A}$ temperatura de ignição nos aços é em torno de 760 a $870{ }^{\circ} \mathrm{C}$
} 
O processo oxicorte permite o corte de aços-carbono e aços baixa-liga podendo cortar virtualmente qualquer espessura ${ }^{5}$ [41]. Entretanto, quando é necessário cortar materiais resistentes à oxidação por este processo, tais como aços inoxidáveis, torna-se necessário a adição de fluxos ou de pó de ferro.

À medida que aumenta o teor de carbono e de outros elementos de liga (principalmente os elementos refratários), há um aumento na dificuldade no oxicorte $[41,42,43]$. Deste modo o oxicorte de uma chapa de aço-carbono ASTM A36 é mais facilmente executado que o oxicorte de uma chapa de aço baixa liga ASTM A514.

$\mathrm{Na}$ Figura 23 é ilustrado esquematicamente o processo de oxicorte e também mostra o oxicorte de uma chapa grossa.

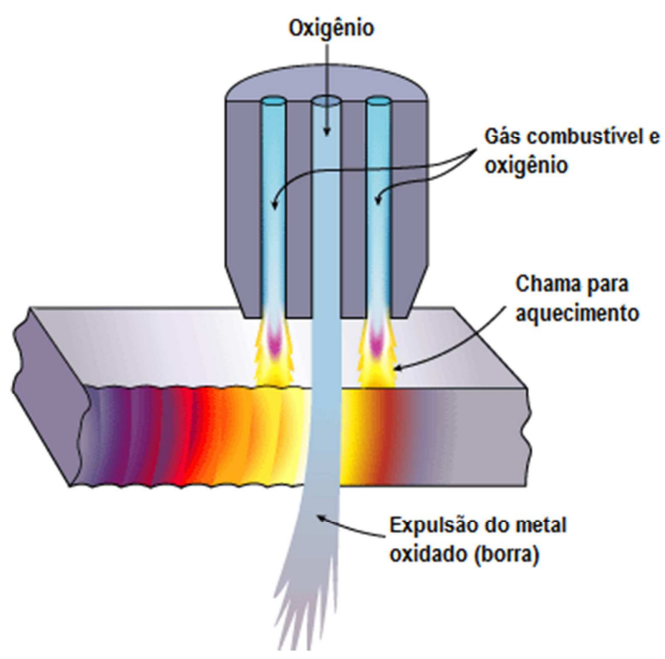

(a)

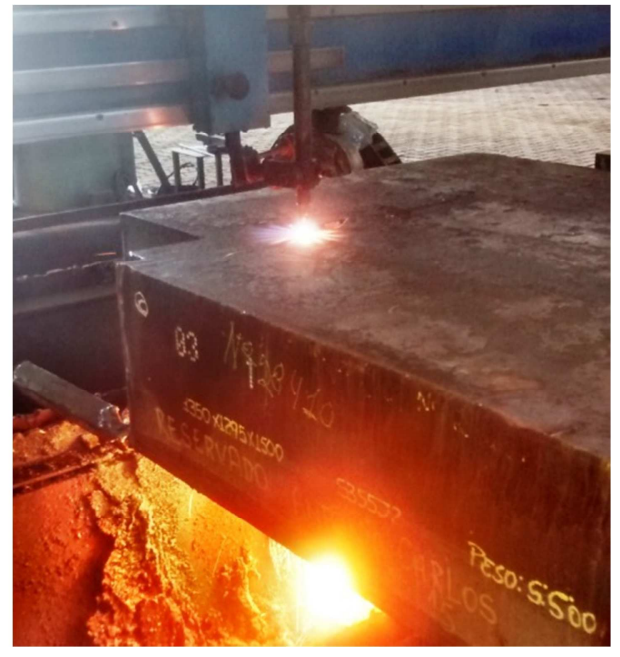

(b)

Figura 23 - (a) llustração esquemática do processo de oxicorte - OFC [38]. (b) Detalhe do oxicorte de uma chapa grossa de $350 \mathrm{~mm}$. Fonte: o autor.

Durante o corte térmico do aço, a temperatura em uma estreita faixa adjacente atinge valores acima da faixa de transformação. À medida que o corte avança, esta faixa sofre um resfriamento, sendo que a sua taxa depende basicamente da condutividade térmica, do calor perdido por convecção e radiação, da massa do material e também da velocidade de corte. Deste modo, muitas vezes a taxa de resfriamento no corte é suficiente para provocar um efeito de têmpera nas arestas de corte, particularmente em cortes espessos onde há grandes massas de metal frio $[42,44]$. Dependendo da quantidade de carbono e dos elementos de liga presentes, e da taxa de resfriamento, aços ferritico-perlíticos transformam-se em microestruturas

\footnotetext{
${ }^{5}$ Consideram-se, nesse caso, espessuras até 60 in. (1525 mm).
} 
que vão de carbonetos esferoidizados até microconstituintes duros. A profundidade aproximada da ZAC varia de 1,0 até 7,0 mm para aços com espessuras de 9,5 até 150 $\mathrm{mm}$ [44].

Enquanto que para aços contendo até $0,25 \%$ o efeito do endurecimento é negligível, o mesmo não acontece para aços médio-carbono (0,25\% até $0,45 \%)$ onde para teores acima de $0,35 \%$ é necessário o preaquecimento da chapa na faixa de 260 a $315^{\circ} \mathrm{C}$ antes do corte a fim de evitar a formação de trincas no resfriamento [42,43]. 0 mesmo cuidado é exigido também no corte de chapas de aços baixa-liga $[42,44]$.

É importante estudar a zona afetada pelo calor produzida pelo corte térmico para entender a variação das propriedades do material ao longo da região de corte onde, no caso dos aços baixa-liga, este efeito é mais considerável. Nestes aços, a região de corte é submetida a transformações metalúrgicas que podem resultar no endurecimento, tanto na superfície do corte, quanto nas regiões mais internas do material [42,44]. Na Figura 24 é mostrado, como exemplo, as microestruturas geralmente formadas após o oxicorte de uma chapa de aço-carbono nas condições de com pré-aquecimento e sem pré-aquecimento.

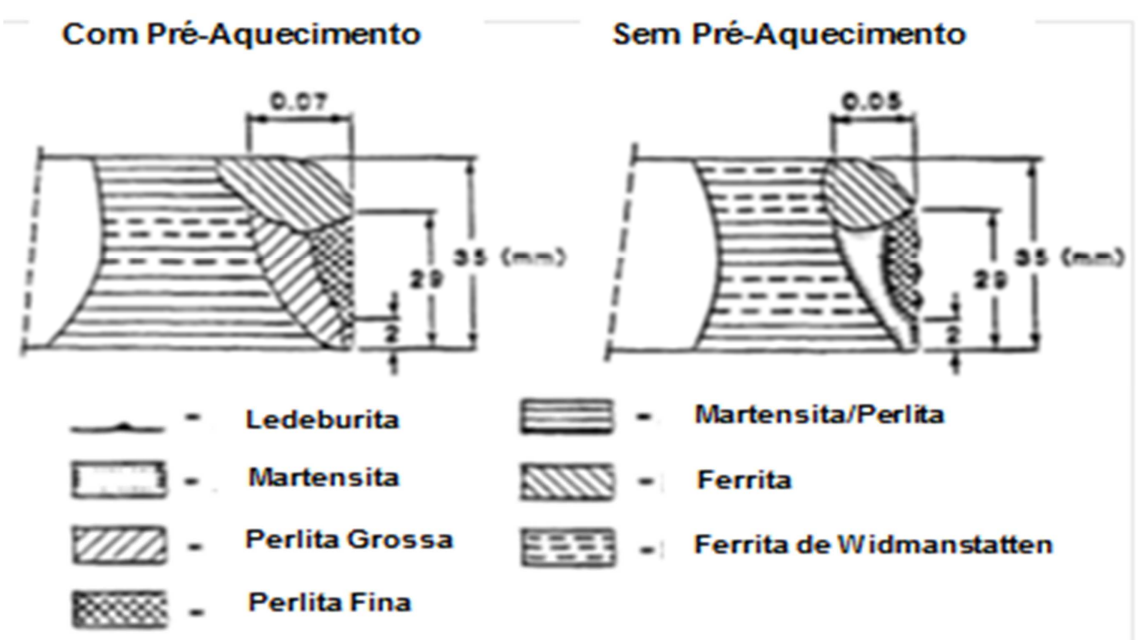

Figura 24 - Microestruturas formadas após corte térmico [40]

Embora o corte com preaquecimento seja a condição mais favorável, pela análise da Figura 24 nota-se que em ambos os casos há a formação de fases frágeis e, assim, uma soldagem direta nestas condições implicaria em uma redução na resistência à fadiga da junta além de potencializar a formação de trincas. Para contornar esta situação, tanto a norma AWS D1.1 [5] quanto a N-133 [6], exigem que a zona afetada pelo calor após o corte de chapas de aços de alta resistência seja removida por usinagem ou esmerilhamento antes da soldagem da junta. 


\subsection{Processos de soldagem para juntas ASTM A36 x ASTM A514}

De acordo com a norma $\mathrm{N}$-133 [6] são permitidos para a soldagem dos aços de alta resistência os processos: eletrodo revestido (SMAW), TIG (GTAW), MAG (GMAW), arame tubular com proteção gasosa (FCAW-G) e arco submerso (SAW). Destes processos apresentados, o processo FCAW-G é o que apresenta a melhor relação de desempenho no aspecto econômico em todas as posições de soldagem e, portanto é um dos mais utilizados pela indústria na atualidade.

O processo arame tubular (FCAW) pode ser definido, conforme a norma AWS 3.0 [18] como um processo de soldagem por arco elétrico entre o metal de adição, alimentado de forma contínua, e a poça de fusão. A proteção da poça de fusão é feita através da mistura gasosa de proteção produzida pelo fluxo contido no arame tubular com proteção adicional (ou não) de um gás ou mistura gasosa fornecida por uma fonte externa. Na Figura 25 é apresentada de forma esquemática uma visão geral do processo e do equipamento utilizado.

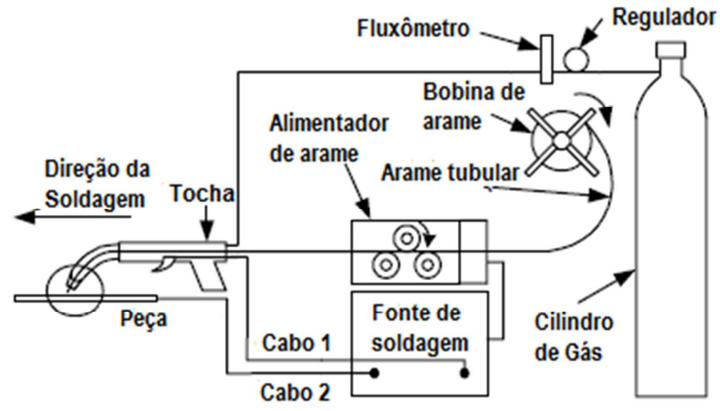

(a)

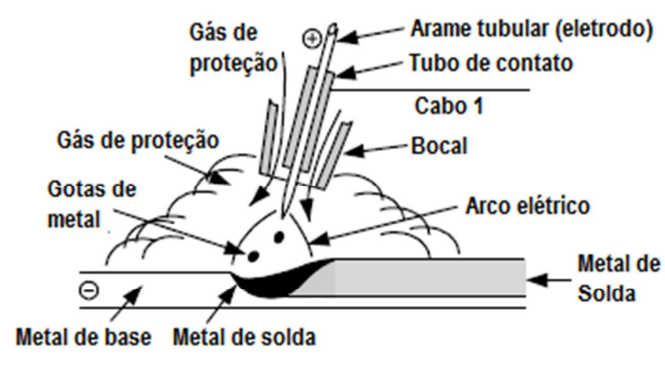

(b)

Figura 25 - (a) Ilustração esquemática do processo FCAW. (b) Detalhe da região da poça de fusão. [13]

Na Figura 26 é mostrado um detalhe da seção transversal ampliada de um arame tubular E71T-1C de bitola 1,2 $\mathrm{mm}$.

$\mathrm{Na}$ soldagem de ligas ferrosas pelo processo FCAW com proteção gasosa, geralmente emprega-se como gás de proteção o $\mathrm{CO}_{2}$ puro ou ainda uma mistura de $\mathrm{Ar}+\mathrm{CO}_{2}$ sendo que a quantidade deste último varia de 8 a $25 \%$. É importante frisar que o gás ou mistura gasosa possuem duas funções principais: criar a coluna de plasma para a condução do arco elétrico e de proteção da poça de fusão. No sentido elétrico, além dos valores de corrente, o tipo de gás ou a composição da mistura exercem forte influência no modo de transferência, sendo que estes modos são semelhantes aos do processo GMAW, a saber: curto circuito e globular [12,33]. 


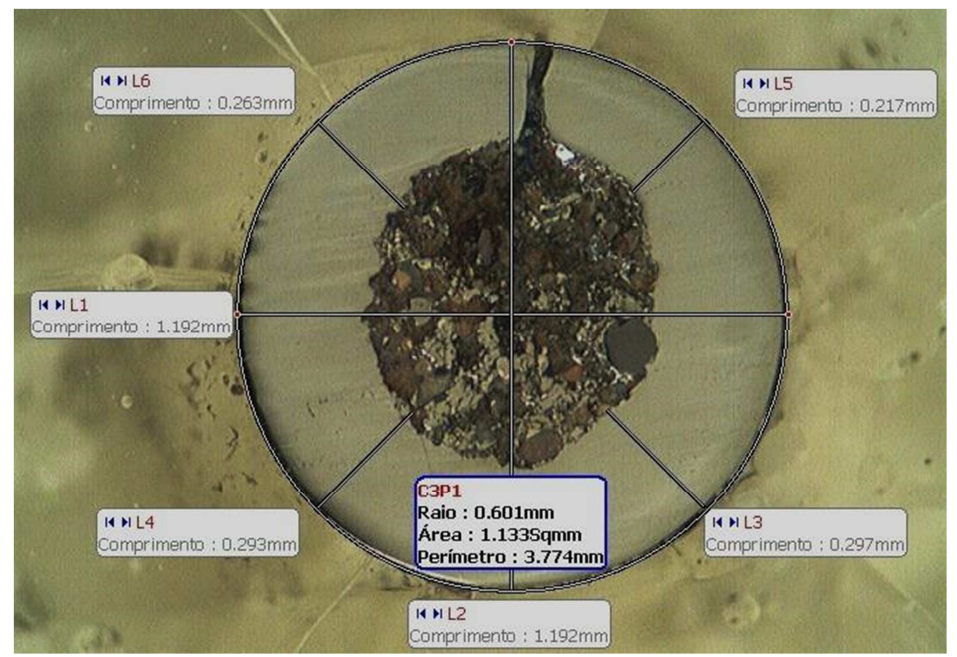

Figura 26 - Geometria do arame e aspecto do fluxo em um corte transversal de uma amostra de arame tubular E71T-1C com bitola de 1,2 mm. Cortesia de Böhler Welding.

$\mathrm{O} \mathrm{CO}_{2}$ puro utilizado como gás de proteção produz muitos respingos durante a soldagem, porém, na soldagem de chapas grossas de aço-carbono é o preferido devido ao alto calor produzido na superfície de trabalho ${ }^{6}$ reduzindo-se com isto a possibilidade de ocorrência de falta de fusão [12,33]. O emprego do $\mathrm{CO}_{2}$ também tem a favor o custo que é relativamente baixo, porém deve ser considerado também 0 custo de mão-de-obra para a remoção dos respingos.

As normas da AWS que especificam os consumíveis empregados no processo FCAW para a soldagem de aços baixo carbono e baixa liga são respectivamente AWS A5.20 [45] e A5.36 [46].

Durante a soldagem a arco, hidrogênio monoatômico é produzido pela decomposição de compostos de hidrogênio em contato com o arco elétrico. Tais compostos de hidrogênio podem ser basicamente: umidade, lubrificantes, pinturas e outros revestimentos, sendo a umidade o preponderante nos consumíveis. Como já discutido no item 3.4 o hidrogênio monoatômico é bastante solúvel na poça de fusão e é retido em solução quando ocorre a solidificação da mesma. Em materiais ferríticos, bainiticos e martensiticos o hidrogênio é capaz de se difundir com facilidade mesmo a temperatura ambiente, embora a taxa de difusão seja diretamente proporcional a temperatura. Existem interações bem estabelecidas entre as microestruturas, as tensões (residuais ou pontos de concentração), tensão de escoamento e hidrogênio

\footnotetext{
${ }^{6}$ Esse calor é decorrente da dissociação e recombinação do dióxido de carbono, cuja molécula diatômica é dissociada em seus átomos componentes quando aquecida nas altas temperaturas do plasma do arco e em seguida é recombinada quando o gás atinge uma superfície relativamente fria, liberando calor neste ponto. Esse calor de recombinação faz com que o dióxido de carbono se comporte como se ele tivesse uma alta condutibilidade térmica similar ao hélio. Dissociação e recombinação não ocorrem com gases monoatômicos, como o argônio [23].
} 
difusível que pode resultar em trincas no metal de solda ou ZAC se estes fatores estão presentes de forma significativa.

Desta forma torna-se necessário medir o teor de hidrogênio difusível no consumível para se determinarem quais são as medidas necessárias a serem adotadas para se evitar a presença de trincas.

Em aços de alta resistência o problema da trinca a frio induzida por hidrogênio é bastante preocupante. Sendo assim, torna-se imprescindível limitar o teor de hidrogênio difusível máximo nos consumíveis. Para o caso do arame tubular, a norma N133 [6] impõe o uso da classe $\mathrm{H} 4$, ou seja, $4 \mathrm{ml} / 100 \mathrm{~g}$ de metal de solda depositado. Por outro lado, a norma AWS D1.1 [5] permite que sejam empregados consumíveis com maior teor de hidrogênio difusível, desde que determinadas condições de préaquecimento da junta sejam respeitadas, de acordo, com o ANEXO I desta norma.

Com relação à composição química do metal de solda deve ser considerado o emprego do $\mathrm{CO}_{2}$ puro, como gás de proteção, o que aumenta a energia de soldagem, reduz a velocidade de resfriamento da solda e possui um caráter oxidante que altera a composição química do depósito em razão das perdas por oxidação de elementos de liga e, assim, reduz a temperabilidade da zona fundida favorecendo portanto a formação de microconstituintes de mais alta temperatura de transformação (ferrita primária de contorno de grão $P G(G)$, ferrita primária intragranular $P F(I)$ e ferrita secundária com segunda fase alinhada $F S(A)$ ) e a redução dos microconstituintes de mais baixa temperatura de transformação (no caso ferrita acicular (AF) e ferrita com segunda fase não-alinhada FS(NA)) [17].

O arame E71T-1C possui uma composição química composta basicamente de carbono e manganês, sendo este último o responsável pelo aumento da tenacidade. Adições de $\mathrm{Ti}$ podem ser benéficas no sentido refinar a microestrutura e assim produzir soldas com maiores valores de tenacidade a baixas temperaturas. De fato, Wegrzyn [20] mostrou através de experimentos que um arame com composição de 1,5Mn-0,8 Si, empregando o gás $\mathrm{CO}_{2}$, deposita soldas com um teor de oxigênio de 560 ppm e mostra uma tenacidade à $-20^{\circ} \mathrm{C}$ de aproxim adamente $70 \mathrm{~J}$, enquanto que o mesmo consumível com uma pequena adição de Ti (até 0,02\%), empregando argônio puro, deposita soldas com um teor de 325 ppm de oxigênio e possui uma tenacidade de $120 \mathrm{~J}$. A partir destes resultados fica evidenciado o efeito dos elementos de liga e do gás de proteção empregados na resistência ao impacto. 


\section{MATERIAIS E MÉTODOS}

\subsection{Materiais}

Os metais de base empregados neste trabalho foram chapas de aço carbono, como laminado, conforme ASTM A36 [2] e chapas de aço baixa liga, temperado e revenido, conforme ASTM A514 Grau Q [3]. As chapas de ASTM A514 foram revenidas a $625^{\circ} \mathrm{C}$. As especificações gerais para am bas as chapas estão de acordo com a norma ASTM A6 [47]. Todas as peças de testes foram removidas de uma chapa com dimensões de $76 \times 2440 \times 6000$ mm de ASTM A36 e outra nas mesmas dimensões de ASTM A514, que foram denominadas "chapas-mãe". A composição química e as propriedades mecânicas estão listadas nas Tabelas 3 e 4 para o ASTM A36 e para o ASTM A514 respectivamente.

Tabela 3 - Composição química da chapa de testes (chapas-mãe) - Valores em \% massa

\begin{tabular}{|c|c|c|c|c|c|c|c|c|c|}
\hline $\begin{array}{l}\text { Elemento } \\
\mathrm{MB}\end{array}$ & C & $\mathrm{Mn}$ & $P$ & $S$ & Si & $\mathrm{Ni}$ & $\mathrm{Cr}$ & Mo & V \\
\hline A36 & $<0,27$ & $\begin{array}{c}0,85- \\
1,20 \\
\end{array}$ & $<0,04$ & $<0,05$ & $\begin{array}{c}0,15- \\
0,40 \\
\end{array}$ & - & - & - & - \\
\hline Certificado & 0,17 & 1,11 & 0,02 & 0,02 & 0,23 & - & - & - & - \\
\hline A514 Gr.Q & $\begin{array}{c}0,14- \\
0,21\end{array}$ & $\begin{array}{c}0,95- \\
1,30\end{array}$ & 0,035 & 0,035 & $\begin{array}{c}0,15- \\
0,35\end{array}$ & $\begin{array}{l}1,20- \\
1,50\end{array}$ & $\begin{array}{l}1,00- \\
1,50\end{array}$ & $\begin{array}{l}0,4- \\
0,60\end{array}$ & $\begin{array}{l}0,03 \\
0,08\end{array}$ \\
\hline Certificado & 0,18 & 1,02 & 0,004 & 0,012 & 0,20 & 1,21 & 1,00 & 0,40 & 0,03 \\
\hline
\end{tabular}

Tabela 4 - Propriedades mecânicas das chapas de testes (chapas-mãe)

\begin{tabular}{|c|c|c|c|c|c|c|}
\hline MB & $\begin{array}{c}\text { TR } \\
{[\mathrm{MPa}]}\end{array}$ & $\begin{array}{c}\mathrm{LE} \\
\text { [MPa] }\end{array}$ & $\begin{array}{c}\underset{A}{\text { Along. }} \\
{[\%]}\end{array}$ & $\begin{array}{l}\text { RA } \\
{[\%]}\end{array}$ & $\begin{array}{c}\text { Durez } \\
\text { a } \\
{[\mathrm{HB}]}\end{array}$ & $\begin{array}{c}\text { Impacto } \\
\text { Charpy } \\
{[\mathrm{J}]}\end{array}$ \\
\hline A36 & $400-550$ & $>250$ & 20 & $>{ }_{B}$ & $>\mathrm{NR}^{B}$ & $N R^{B}$ \\
\hline Certificado & 468 & 274 & 32 & 59 & - & - \\
\hline A514 Gr.Q & $690-895$ & $>620$ & $>16$ & $>50$ & $\mathrm{NR}^{B}$ & $\mathrm{NR}^{B}$ \\
\hline Certificado & 785 & 700 & 23 & 69 & - & - \\
\hline
\end{tabular}

Os consumíveis empregados neste trabalho foram o gás $\mathrm{CO}_{2}$ puro conforme AWS 5.32 [48] que foi empregado como gás de proteção na soldagem e o arame tubular AWS 5.20 E71T1-C(M)H5 [45] na bitola de 1,2 mm. O arame tubular possui teor de hidrogênio máximo difusível inferior a $5 \mathrm{ml} / 100 \mathrm{~g}$ e os valores do certificado de qualidade estão listados nas Tabelas 5 e 6 . As propriedades do gás $\mathrm{CO}_{2}$ estão descritas na Tabela 7. 
Tabela 5 - Composição química do metal depositado - Arame tubular E71T1-C

\begin{tabular}{c|c|c|c|c|c|c|c|c|c}
\hline $\begin{array}{c}\text { elemento } \\
\mathrm{MA}\end{array}$ & $\mathrm{C}$ & $\mathrm{Mn}$ & $\mathrm{P}$ & $\mathrm{S}$ & $\mathrm{Si}$ & $\mathrm{Ni}$ & $\mathrm{Cr}$ & $\mathrm{Mo}$ & $\mathrm{V}$ \\
\hline $\begin{array}{c}\text { Arame } \\
\text { tubular } \\
\text { E71T1-C }\end{array}$ & 0,12 & 1,75 & 0,030 & 0,030 & 0,90 & 0,50 & 0,20 & 0,30 & 0,08 \\
\hline Certificado & 0,05 & 1,21 & 0,015 & 0,011 & 0,53 & 0,02 & 0,01 & 0,02 & 0,02 \\
\hline
\end{tabular}

Tabela 6 - Propriedades mecânicas metal depositado- Arame tubular E71T1-C

\begin{tabular}{c|c|c|c|c|c|c}
\hline Propriedade & $\begin{array}{c}\mathrm{TR} \\
{[\mathrm{MPa}]}\end{array}$ & $\begin{array}{c}\mathrm{LE} \\
{[\mathrm{MPa}]}\end{array}$ & $\begin{array}{c}\text { Along. }^{A} \\
{[\%]}\end{array}$ & $\begin{array}{c}\mathrm{RA} \\
{[\%]}\end{array}$ & $\begin{array}{c}\text { Dureza } \\
{[\mathrm{HB}]}\end{array}$ & $\begin{array}{c}\text { Impacto } \\
\text { Charpy } \\
-20{ }^{\circ} \mathrm{C} \\
{[\mathrm{J}]}\end{array}$ \\
\hline $\begin{array}{c}\text { Arame tubular } \\
\text { E71T1-C }\end{array}$ & $490-670$ & $>390$ & $>22$ & $\mathrm{NA}^{B}$ & $\mathrm{NA}^{B}$ & 27 \\
\hline Certificado & 589 & 520 & 31 & - & - & 60 \\
\hline \multicolumn{7}{|c}{ Corpo de prova de $50 \mathrm{~mm}$ e } \\
\hline
\end{tabular}

Tabela 7 - Propriedades do gás de proteção $\mathrm{CO}_{2}$

\begin{tabular}{c|c|c|c}
\hline Estado & $\begin{array}{c}\text { Pureza mínima } \\
{[\%]}\end{array}$ & $\begin{array}{c}\text { Ponto de Orvalho } \\
{\left[{ }^{\circ} \mathrm{C}\right]}\end{array}$ & $\begin{array}{c}\text { Umidade máxima } \\
\text { a } 1 \text { atm } \\
{[\mathrm{ppm}]}\end{array}$ \\
\hline Líquido & 99,8 & -51 & 62 \\
\hline
\end{tabular}

\subsection{Métodos}

\subsubsection{Caracterização do Metal de Base (MB) e do Metal de Adição (MA)}

As etapas desta parte do trabalho estão descritos nos itens abaixo:

1 - Confirmação das especificações dos metais de base quanto à composição química conforme as normas ASTM A36 e ASTM A514 Grau Q pela análise por espectrometria de emissão óptica e baseada na norma ASTM A6;

2 - Determinação da espessura a ser removida por usinagem da face oxicortada através da avaliação e caracterização desta região nos metais de base ASTM A36 e ASTM A514;

3 - Determinação da temperatura de pré-aquecimento adequada para a soldagem das juntas de ASTM A36 com ASTM A514 Grau Q por meio de testes de soldabilidade do tipo CTS - Controlled Thermal Severity; 
4 - Determinação do teor de hidrogênio dissolvido do metal de adição (THD) conforme a norma AWS A4.3-93 (R2006) [49] de modo a assegurar que o consumível contivesse um teor máximo de $4 \mathrm{ml} / 100 \mathrm{~g}$

\subsubsection{Análise da composição química das chapas}

A análise química foi realizada a temperatura ambiente de ${ }^{24} \mathrm{C}$ e umidade relativa de $40 \%$ por meio de um espectrômetro de emissão óptica marca ARL Modelo 3460 devidamente calibrado.

\subsubsection{Determinação da espessura mínima a ser removida das faces oxicortadas}

Foram preparadas duas peças de testes, denominadas PT-01 para o ASTM A36 e PT-02 para o ASTM A514 Grau Q.

Ambas as peças de testes, PT-01 e PT-02, foram oxicortadas nas dimensões de $50 \times 76 \times 200 \mathrm{~mm}$ e foram removidas no canto da extremidade de uma chapa de dimensões $76 \times 2440 \times 6000$ mm de ASTM A36 e ASTM A514. A remoção foi executada por uma máquina de oxicorte CNC com velocidade de corte de $240 \mathrm{~mm} / \mathrm{min}$ para as peças de teste.

As peças de teste foram submetidas a exame macrográfico (com perfil de durezas) e micrográfico. Na Figura 27 são mostrados os locais das análises e da remoção dos corpos de prova.

O exame macrográfico foi preparado e ensaiado conforme a norma ASTM E340-13 [50]. O ataque foi realizado com Nital 5\% e a inspeção realizada com o auxílio de uma lupa com ampliação de 10X.

Em seguida, aproveitando os corpos de prova do exame macrográfico, foram realizadas as medições de microdureza Vickers, em ambas peças de testes nas linhas de $1,5 \mathrm{~mm}, 19 \mathrm{~mm}$ e meio raio a contar da superfície laminada. Em cada linha foram feitas 13 medições e o espaçamento entre estas foi de $0,2 \mathrm{~mm}$. O ensaio de microdureza Vickers foi realizado à temperatura ambiente de $23^{\circ} \mathrm{C}$, empregando-se um durômetro Mitutoyo - DUR 024, devidamente calibrado. A preparação dos corpos de prova e o método de ensaio foram executados conforme a norma ASTM E384-11 E1 [51]. 


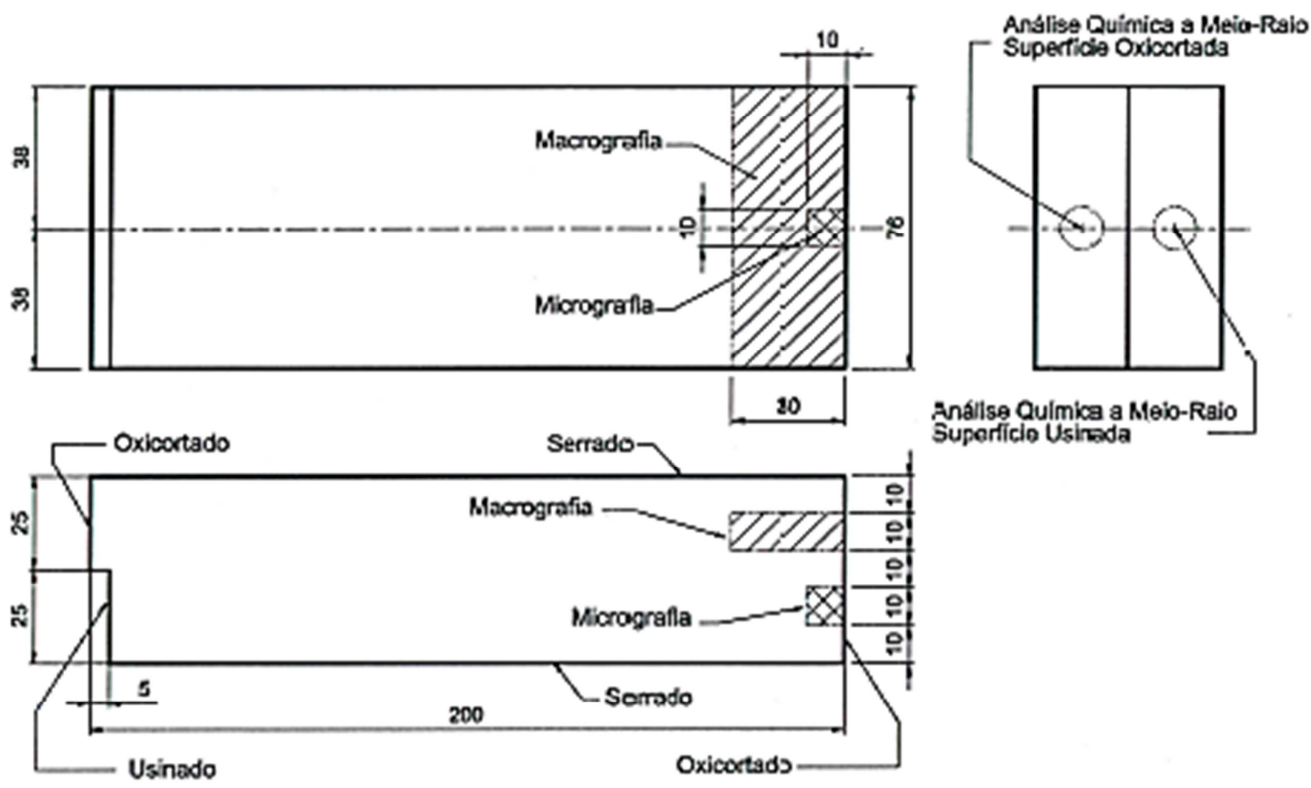

Figura 27 - Dimensões das peças de testes PT-01 e PT-02 e locais de remoção dos corpos de prova

Os corpos de prova das micrografias foram preparados conforme a norma ASTM E3-11 [52]. O ataque foi realizado com Nital 2\% e a análise da microestrutura foi executada por meio de um microscópio óptico Olympus GX 51.

\subsubsection{Determinação do hidrogênio difusível do metal de adição}

Os testes para a determinação do hidrogênio difusível do arame E71T1-C utilizado neste trabalho foram conduzidos conforme a norma AWS A4.3-93 (R2006) [49]. Foram preparados três corpos de prova em aço carbono ASTM A36 de dimensões $12 \times 25 \times 80 \mathrm{~mm}$. Tais corpos de prova sofreram desgaseificação a vácuo em forno a $400^{\circ} \mathrm{C}$ por 12 horas para a remoção de qua lquer hidrogênio presente. $A$ seguir, os corpos de prova foram devidamente identificados, limpos e pesados em balança analítica. Após a montagem no dispositivo os CP's foram soldados, em um dia chuvoso, conforme os parâmetros indicados na Tabela 8. O gás de proteção utilizado foi o $\mathrm{CO}_{2}$ conforme AWS 5.32 SG-C com vazão na faixa de $15-18 \mathrm{lpm}$.

Cada corpo de prova após soldagem foi imediatamente imerso em nitrogênio líquido e mantido a baixa temperatura até o momento da análise. Neste momento, os CP's foram limpos em álcool isopropílico, pesados em balança analítica, e analisados por cromatografia a gás empregando um equipamento marca JUWE - M Mat 221. Na Figura 28 são observados os CP's prontos para análise no cromatógrafo e 0 equipamento utilizado nesta análise. 
Tabela 8 - Parâmetros de soldagem utilizados na soldagem dos CP's para determinação do hidrogênio difusível do metal de solda

\begin{tabular}{c|c|c|c|c|c}
\hline CP n. $^{\circ}$ & $\begin{array}{c}\text { Tensão } \\
{[\mathrm{V}]}\end{array}$ & $\begin{array}{c}\text { Corrente } \\
{[\mathrm{A}]}\end{array}$ & Polaridade & $\begin{array}{c}\text { Comprimento } \\
\text { Soldado } \\
{[\mathrm{mm}]}\end{array}$ & $\begin{array}{c}\text { Tempo de } \\
\text { Soldagem } \\
{[\mathrm{s}]}\end{array}$ \\
\hline 01 & $22-24$ & $218-223$ & $\mathrm{CC}+$ & 80 & 6 \\
\hline 02 & $22-24$ & $214-225$ & $\mathrm{CC}+$ & 80 & 7 \\
\hline 03 & $22-24$ & $216-222$ & $\mathrm{CC}+$ & 80 & 7 \\
\hline
\end{tabular}

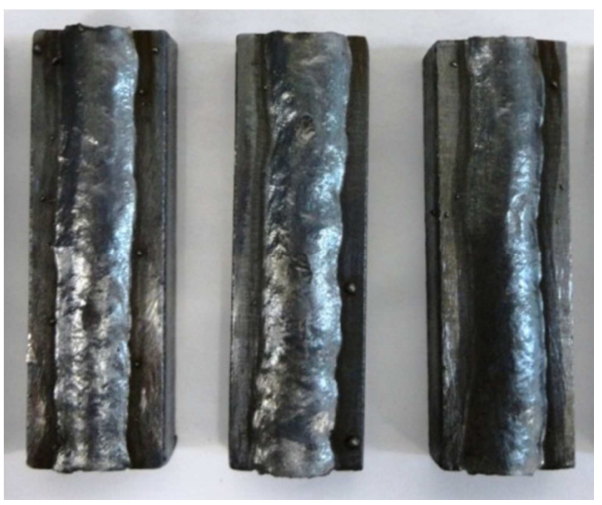

(a)

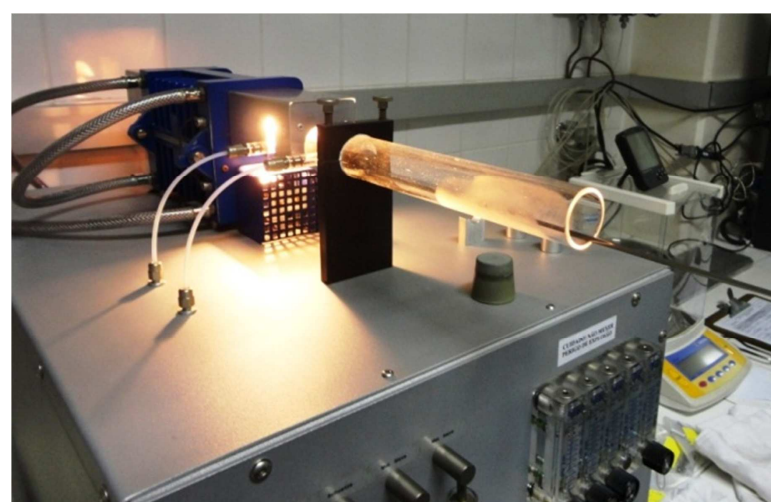

(b)

Figura 28 - (a) Corpos de prova para determinação do hidrogênio difusível do metal de solda.

(b) Detalhe do cromatógrafo JUWE - M Mat221.

\subsubsection{Determinação da temperatura mínima de preaquecimento}

A determinação da temperatura mínima de preaquecimento para a soldagem foi determinada por meio do procedimento proposto pela norma AWS D1.1 [5], sendo comparada aos modelos matemáticos propostos pela norma DIN EN 1011-2 Método B (C.3) [31], sendo que a memória de cálculo encontra-se nos Anexos A e B deste trabalho. Em seguida os valores obtidos foram comprovados a partir de testes de soldabilidade.

Os testes de soldabilidade foram realizados em peças de teste do tipo CTS Controlled Thermal Severity, modificados em virtude das espessuras da chapa, porém as dimensões básicas foram mantidas. Na Figura 29 são mostrados os detalhes construtivos das peças de teste.

Os blocos inferiores de dimensões $76 \times 100 \times 250 \mathrm{~mm}$ foram oxicortados do material de partida ASTM A36. Os blocos superiores de dimensões $76 \times 75 \times 75 \mathrm{~mm}$ foram fresados a partir de peças oxicortadas do material de partida ASTM A514 com o 
sobremetal necessário para a operação subsequente de usinagem. Deste modo a ZAC no A514 foi eliminada.
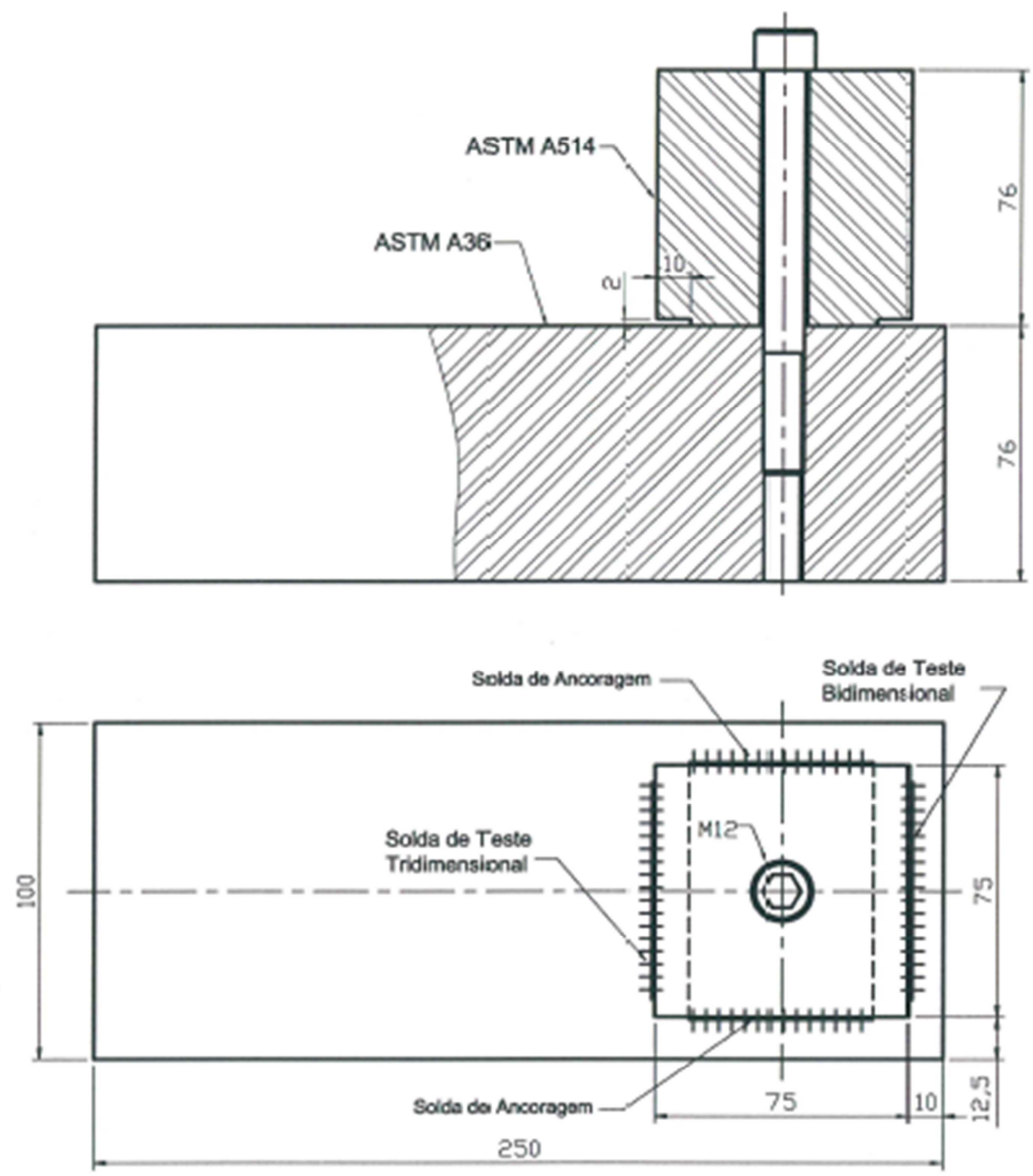

Figura 29 - Peça de teste tipo CTS - Controlled Thermal Severity - dimensões em mm.

Foram impostas três condições: sem preaquecimento (condição A), com preaquecimento de $110^{\circ} \mathrm{C}^{7}$ (condição B) e com preaquecimento de $160^{\circ} \mathrm{C}{ }^{8}$ (condição C).

A condição "sem preaquecimento" foi simulada tendo-se em vista verificar os efeitos de uma possível soldagem executada a temperatura ambiente, ou seja, na condição mais severa. As demais condições foram atribuídas conforme os requisitos da norma AWS D1.1.

Para simular as três condições impostas foram preparadas quinze peças de teste CTS sendo distribuídas cinco peças para cada condição ( $A, B$ e $C$ ). Assim, as

\footnotetext{
${ }^{7}$ Conforme a Tabela 4.9 da norma AWS D1.1/D1.1M:2010

${ }^{8}$ Conforme o Anexo I-Guideline on Alternative Methods for Determining Preheat da norma AWS D1.1/D1.1M:2010
} 
peças de testes foram designadas do seguinte modo: PT-03A-1 a 5 para a condição A; PT-03B-1 a 5 para a condição B; PT-03C-1 a 5 para a condição C.

As quinze peças foram soldadas em um dia chuvoso, temperatura ambiente de $1^{\circ} \mathrm{C}$, com umidade relativa do ar de $80 \%$. As soldas de teste bidimensional (2D) e tridimensional (3D) foram fabricadas pelo processo Arame Tubular com uma fonte marca Miller modelo XMT 456. A soldagem foi feita na posição horizontal 2F. Os consumíveis empregados foram o arame tubular conforme AWS 5.20 E71T-1C(M)H5 e o gás de proteção na vazão de 15 - 18 lpm, conforme AWS 5.32 SG-C ambos descritos no item "Materiais".

O preaquecimento, onde aplicável, foi realizado por meio de maçarico e o controle da temperatura feito por meio de pirômetro de contato.

Os parâmetros de soldagem medidos em cada peça de testes estão descritos na Tabela 9. As medições foram realizadas através de alicate-amperímetro devidamente calibrado.

Tabela 9 - Parâmetros de soldagem das peças de teste tipo CTS

\begin{tabular}{c|c|c|c|c|c}
\hline & $\begin{array}{c}\text { Corrente } \\
{[\mathrm{A}]}\end{array}$ & $\begin{array}{c}\text { Tensão } \\
{[\mathrm{V}]}\end{array}$ & $\begin{array}{c}\text { Velocidade de } \\
\text { Soldagem } \\
{[\mathrm{cm} / \mathrm{min}]}\end{array}$ & $\begin{array}{c}\text { Eficiência do } \\
\text { Arco } \\
{[\%]}\end{array}$ & $\begin{array}{c}\text { Aporte de } \\
\text { Calor Máximo } \\
{[\mathrm{kJ} / \mathrm{mm}]}\end{array}$ \\
\hline $\begin{array}{c}\text { Faixa de } \\
\text { Valores }\end{array}$ & $115-135$ & $23-24$ & $28-32$ & $85[15]$ & 0,5 \\
\hline
\end{tabular}

Após a soldagem as peças foram resfriadas ao ar calmo.

Depois de decorridas 48 horas $^{9}$ foram realizados o exame visual de soldagem e o ensaio de líquido penetrante nas juntas soldadas.

$\mathrm{Na}$ Figura 30 é indicada a posição de retirada dos corpos de prova para a macrografia.

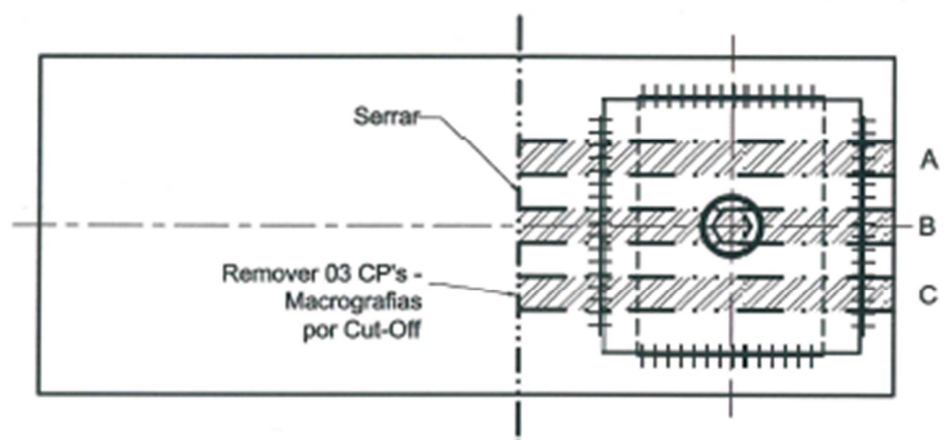

Figura 30 - Preparação das peças de teste tipo CTS para a remoção dos corpos de prova destinados ao exame macrográfico

\footnotetext{
${ }^{9}$ Conforme item 6.11 da norma AWS D1.1/D1.1M:2010 que estabelece o tempo mínimo para a inspeção após finalizada a soldagem do A514.
} 
O exame macrográfico foi preparado e ensaiado conforme a norma ASTM E340/2006 [50]. O ataque foi realizado com Nital 5\% e a inspeção realizada com o auxílio de uma lupa com ampliação de 10X.

Nas juntas onde foi constatada a presença de trincas, foi embutido um CP para exame por microscopia ótica.

\subsubsection{Preparação e qualificação da soldagem}

Esta etapa teve como objetivo principal a qualificação de um procedimento de soldagem de uma junta de ASTM A36 com ASTM A514 conforme a norma AWS D1.1.

Uma peça após a realização da soldagem foi seccionada na direção transversal dando origem a duas peças de testes, à saber: PT-04 e PT-05. A preparação das peças de teste consistiu inicialmente na etapa de corte onde foram oxicortadas em máquina CNC, uma chapa de ASTM A36 e outra de ASTM A514 nas dimensões $76 \times 200 \times 1100 \mathrm{~mm}$. As chapas foram cortadas de modo que a solda ficasse posicionada na direção transversal ao sentido de laminação da chapa. A chapa de ASTM A36 foi biselada por oxicorte e depois esmerilhada ao metal brilhante nas faces do bisel e a $25 \mathrm{~mm}$ nas margens da junta. A chapa de ASTM A514 teve o lado da junta fresado onde foi removido $3,0 \mathrm{~mm}$ de sobremetal de modo a eliminar a ZAC formada na operação anterior do corte térmico. Os dois membros da junta foram posicionados de modo a formar uma junta do tipo "K" com ângulo de chanfro de $50^{\circ} \mathrm{e}$ abertura de raiz de $3 \mathrm{~mm}$. Foram montados os dispositivos auxiliares de montagem ("babadores", "cachorros" e "batoques"). Na Figura 31 são mostrados os detalhes da junta após a preparação.

A peça de testes foi posicionada e fixada na posição vertical (3G) para a soldagem. Em seguida foi preaquecida por meio de maçarico até atingir uma temperatura de $160^{\circ} \mathrm{C}$ que foi controlada por meio de pirômetro de contato.

A peça foi soldada em um dia com umidade relativa do ar de $35 \%$. A junta foi soldada pelo processo Arame Tubular (FCAW) com uma fonte de soldagem marca Miller modelo XMT 456. Os consumíveis empregados foram o arame tubular na bitola de 1,2 mm conforme AWS 5.20 E71T-1C(M)H5 e o gás conforme AWS 5.32 SG-C ambos descritos no item "Materiais".

Os parâmetros de soldagem empregados na peça de testes estão descritos detalhadamente no Anexo C. As medições foram realizadas por alicate-amperímetro, cronômetro e pirômetros de contato devidamente calibrados. A peça foi soldada na progressão ascendente onde foram depositados 76 passes sendo depositados 8 
passes de um lado e depois foi executada a goivagem com eletrodo de grafite e esmerilhamento pelo lado oposto. $\mathrm{Na}$ Tabela 10 é mostrado o intervalo dos parâmetros empregados.

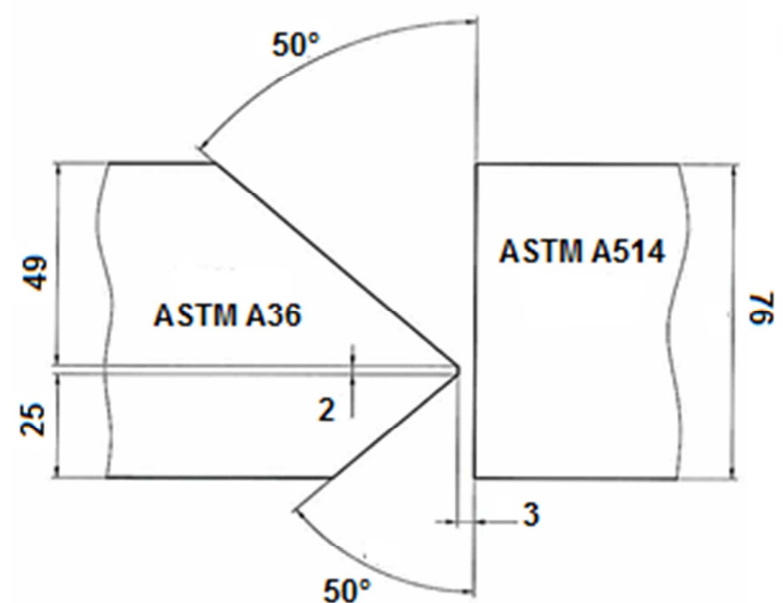

(a)

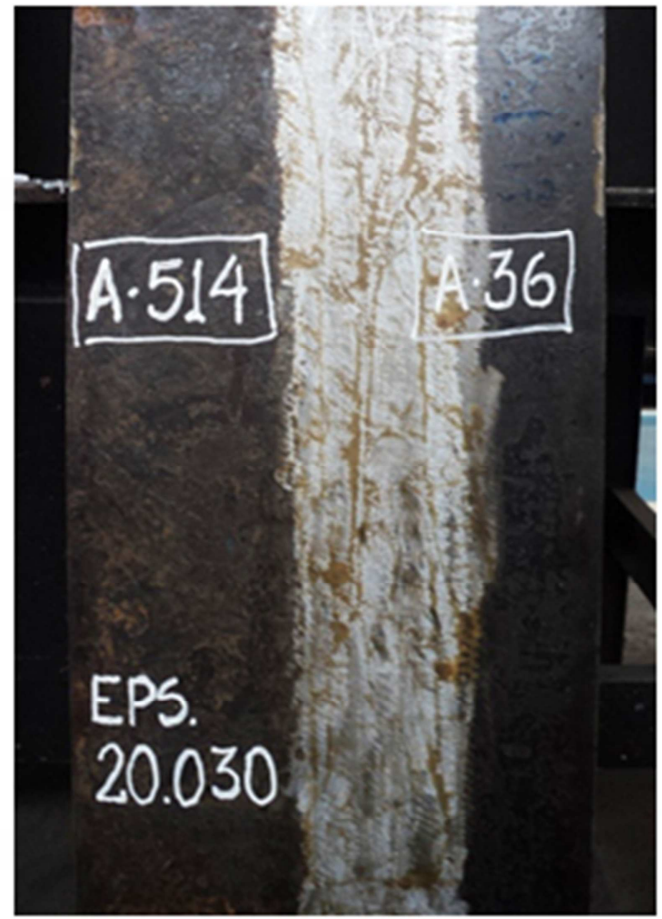

(b)

Figura 31 - (a) Detalhe da preparação da junta em $\mathrm{K}$ na condição 1/3 e 2/3 para posterior goivagem da raiz. (b) Peças de testes PT-04/PT-05 soldada e com o reforço de solda removido para posterior inspeção por ultrassom.

Tabela 10 - Parâmetros de soldagem das peças de teste PT-04 e PT-05 ${ }^{10}$

\begin{tabular}{c|c|c|c|c}
\hline & $\begin{array}{c}\text { Corrente } \\
{[\mathrm{A}]}\end{array}$ & $\begin{array}{c}\text { Tensão } \\
{[\mathrm{V}]}\end{array}$ & $\begin{array}{c}\text { Velocidade de } \\
\text { Soldagem } \\
{[\mathrm{cm} / \mathrm{min}]}\end{array}$ & $\begin{array}{c}\text { Aporte de } \\
\text { Calor } \\
{[\mathrm{kJ} / \mathrm{mm}]}\end{array}$ \\
\hline Valor mínimo & 110 & 22 & 7,0 & 0,8 \\
\hline Valor máximo & 189 & 28 & 30,8 & 3,2 \\
\hline
\end{tabular}

Concluída a soldagem, a peça sofreu um pós-aquecimento a $200{ }^{\circ} \mathrm{C}$ por meio de estufa por 30 minutos.

Após 48 horas $^{11}$, foram realizadas as análises de exame visual de soldagem e o ensaio de líquido penetrante conforme mencionado, respectivamente, na AWS D1.1 itens 6.9 e 6.10 .

\footnotetext{
${ }^{10}$ Os parâmetros empregados encontram-se na faixa usual daqueles utilizados na soldagem de peças na posição vertical ascendente.

${ }^{11}$ Conforme item 6.11 da norma AWS D1.1/D1.1M:2010 que estabelece o tempo mínimo para a inspeção após finalizada a soldagem do A514.
} 
Para o exame de ultrassom, os reforços da face e da raiz foram removidos por esmerilhamento $^{12}$ e o ensaio executado após 48 horas da soldagem, conforme AWS D1.1 item 6.13 considerando o critério de aceitação para conexões não tubulares estaticamente carregadas. Na Figura 31 é apresentada a peça de teste preparada para o ensaio de ultrassom.

A seguir a peça foi seccionada transversalmente, de modo a se obter duas peças de testes: PT-04 e PT-05 de dimensões 76 × 403 x 550 mm cada uma. A PT-04 permaneceu na condição inicial "como soldado" (CS) enquanto que, a PT-05 sofreu tratamento térmico de alívio de tensões após a soldagem (TTAT). O tratamento térmico aplicado a PT-05 foi conforme o item 5.8 da norma AWS D1.1 e os parâmetros utilizados encontram-se listados na Tabela 11. A peça de testes foi submetida a dois ciclos de alívio de tensões empregando os mesmos parâmetros ${ }^{13}$.

Tabela 11 - Parâmetros de tratamento térmico da PT-05

\begin{tabular}{|c|c|c|c|}
\hline \multirow{2}{*}{ Parâmetros } & \multirow{2}{*}{$\begin{array}{c}\text { Norma } \\
\text { AWS D1.1 }\end{array}$} & \multicolumn{2}{|c|}{ Valores Obtidos } \\
\hline & & $1 .^{\circ} \mathrm{Ciclo}$ & 2. ${ }^{\circ} \mathrm{Ciclo}$ \\
\hline Temperatura de início de controle & $315^{\circ} \mathrm{C}$ & $300^{\circ} \mathrm{C}$ & $300^{\circ} \mathrm{C}$ \\
\hline Taxa de aquecimento máxima a partir de $315^{\circ} \mathrm{C}$ & $55^{\circ} \mathrm{C} / \mathrm{h}$ & $50^{\circ} \mathrm{C} / \mathrm{h}$ & $50^{\circ} \mathrm{C} / \mathrm{h}$ \\
\hline Temperatura de patamar & $600^{\circ} \mathrm{C}$ & $600^{\circ} \mathrm{C}$ & $600^{\circ} \mathrm{C}$ \\
\hline Tempo de patamar & $3 \mathrm{~h}$ & $3 \mathrm{~h}$ & $3 \mathrm{~h}$ \\
\hline Taxa de resfriamento máxima até $315^{\circ} \mathrm{C}$ & $130^{\circ} \mathrm{C} / \mathrm{h}$ & $100^{\circ} \mathrm{C} / \mathrm{h}$ & $100^{\circ} \mathrm{C} / \mathrm{h}$ \\
\hline
\end{tabular}

O tratamento térmico foi realizado em um forno elétrico do tipo mufla, sem atmosfera controlada, com controlador de temperatura Marca Contemp, termopar tipo $\mathrm{K}$ e registrador gráfico digital Pointer Master 200 devidamente calibrados.

$\mathrm{Na}$ etapa de resfriamento, quando a peça atingiu $300^{\circ} \mathrm{C}$ ela foi removida do forno e esfriada ao ar calmo até atingir a temperatura ambiente.

Em seguida, a peça foi escovada e submetida a um novo exame por ultrassom conforme a norma AWS D1.1 item 6.13.

Os corpos de prova foram removidos conforme item 4.9 da norma AWS D1.1. O Anexo D indica os locais de remoção dos CP's.

\footnotetext{
${ }^{12}$ A remoção do reforço é necessária quando o comprimento de varredura do cabeçote do ultra-som é insuficiente.

${ }^{13} \mathrm{Em}$ geral, na qualificação de um procedimento de soldagem com alívio de tensões, é recomendado que a peça de testes seja submetida a dois ciclos prevendo-se uma possível necessidade de reparos caso a junta do equipamento seja reprovada em algum ensaio não-destrutivo e assim seja necessário uma nova soldagem com posterior tratamento térmico de alívio de tensões.
} 
As peças de testes PT-04 e PT-05 foram então submetidas aos ensaios mecânicos de: ensaio de tração e dobramento lateral.

$\mathrm{Na}$ Tabela 12 são mencionados os ensaios, a quantidade e as dimensões dos corpos de prova e os itens aplicáveis da norma.

Devido a espessura da peça de testes, a nota "f" da Figura 4.14 da norma AWS D1.1 prevê que os corpos de prova podem ser cortados em, aproximadamente, 2 tiras iguais de modo a formar um único set de ensaios.

Tabela 12 - Normas aplicáveis aos ensaios mecânicos e metalográficos

\begin{tabular}{l|c|c|c|c|c}
\hline \multicolumn{1}{c|}{ Tipo } & Qt. & Norma & Preparação & Ensaio & Aceitação \\
\hline $\begin{array}{l}\text { Tração Seção } \\
\text { Reduzida }\end{array}$ & $\begin{array}{c}\text { 02 jogos de } \\
\text { 02 CP's cada }\end{array}$ & AWS D1.1 & 4.9 .3 .4 & 4.9 .3 .4 & 4.9 .3 .5 \\
\hline $\begin{array}{l}\text { Dobramento } \\
\text { Lateral }\end{array}$ & 04 & AWS D1.1 & 4.9 .3 .1 & 4.9 .3 .1 & 4.9 .3 .3 \\
\hline Macrografia & 01 & AWS D1.1 & $\begin{array}{c}\text { ASTM E340 } \\
{[50]}\end{array}$ & 4.9 .4 & 4.9 .4 .1 \\
\hline
\end{tabular}

\subsubsection{Caracterização da junta soldada}

Esta etapa consistiu na caracterização da junta soldada por meio dos ensaios de dureza, impacto, fractografia, e caracterização microestrutural.

A macrografia foi preparada através do lixamento com lixas d'água (granulometrias de 100, 240,320,400, 660 e 1000) sendo o ataque realizado com Nital 5\%.

Os corpos de prova foram removidos conforme item 4.9 da norma AWS D1.1. O Anexo D indica os locais de remoção dos CP's.

$\mathrm{Na}$ Tabela 13 são apresentados os ensaios, as quantidades e as dimensões dos corpos de prova e as normas aplicáveis.

Tabela 13 - Normas aplicáveis aos ensaios mecânicos e metalográficos

\begin{tabular}{l|c|c|c|c|c}
\hline \multicolumn{1}{c|}{ Tipo } & Quantidade & Norma & Preparação & Ensaio & Aceitação \\
\hline $\begin{array}{l}\text { Perfil de } \\
\text { Durezas } \\
\text { (carga 5kgf) }\end{array}$ & $\begin{array}{c}01(29 \\
\text { pontos })\end{array}$ & N133 & $\begin{array}{c}\text { ASTM E384 } \\
{[51]}\end{array}$ & N133 & - \\
\hline $\begin{array}{l}\text { Impacto } \\
\text { Charpy (-20C) }\end{array}$ & $\begin{array}{c}\text { 01 jogo de 03 } \\
\text { CP's em cada } \\
\text { posição }\end{array}$ & AWS D1.1 & $\begin{array}{c}\text { ASTM A370 } \\
{[52]}\end{array}$ & ASTM A370 & $\begin{array}{c}\text { AWS D1.1 } \\
4.37\end{array}$ \\
\hline Micrografia & 05 & - & $\begin{array}{c}\text { ASTM E3 } \\
{[53]}\end{array}$ & $\begin{array}{c}\text { ASTM E7 } \\
{[54]}\end{array}$ & - \\
\hline
\end{tabular}


Na Figura 32 são mostrados os locais de medição de dureza. Em caráter suplementar à norma $\mathrm{N} 133$ foram adicionados dois pontos na região dos metais de base, um ponto nas linhas I e III e dois pontos na linha II na região do metal de solda, de modo que todas as regiões tivessem três pontos de medição.

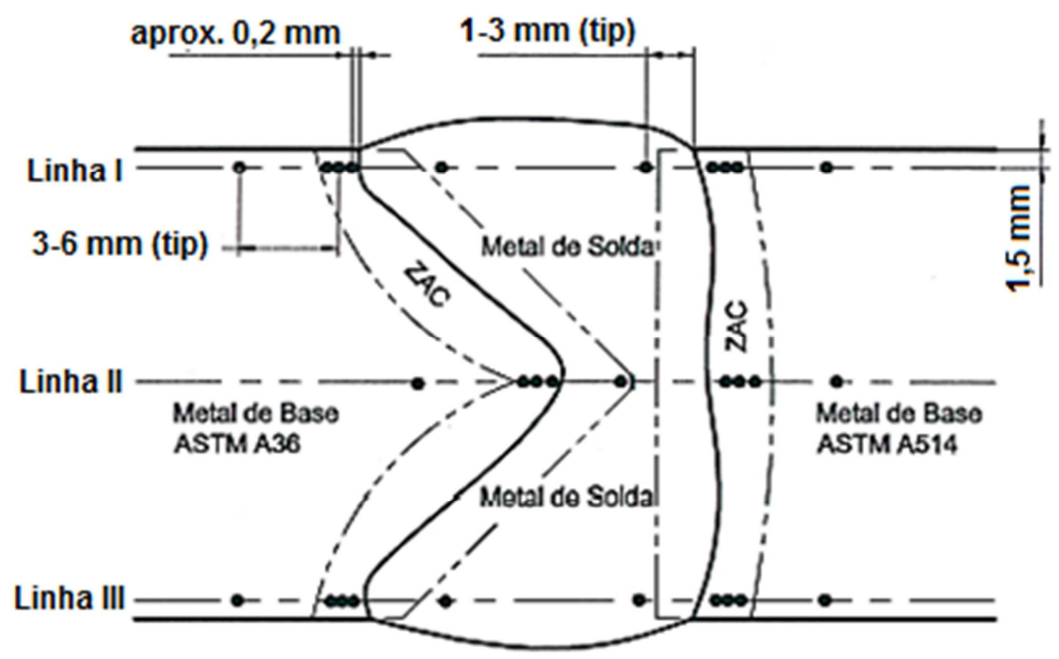

Figura 32 - Localização dos pontos de medição de dureza Vickers HV5 conforme norma PETROBRAS N-133 rev.K.

Na Figura 33 estão indicados os locais de remoção dos corpos de prova para ensaio de impacto Charpy. A temperatura de ensaio foi de $-20^{\circ} \mathrm{C}$.
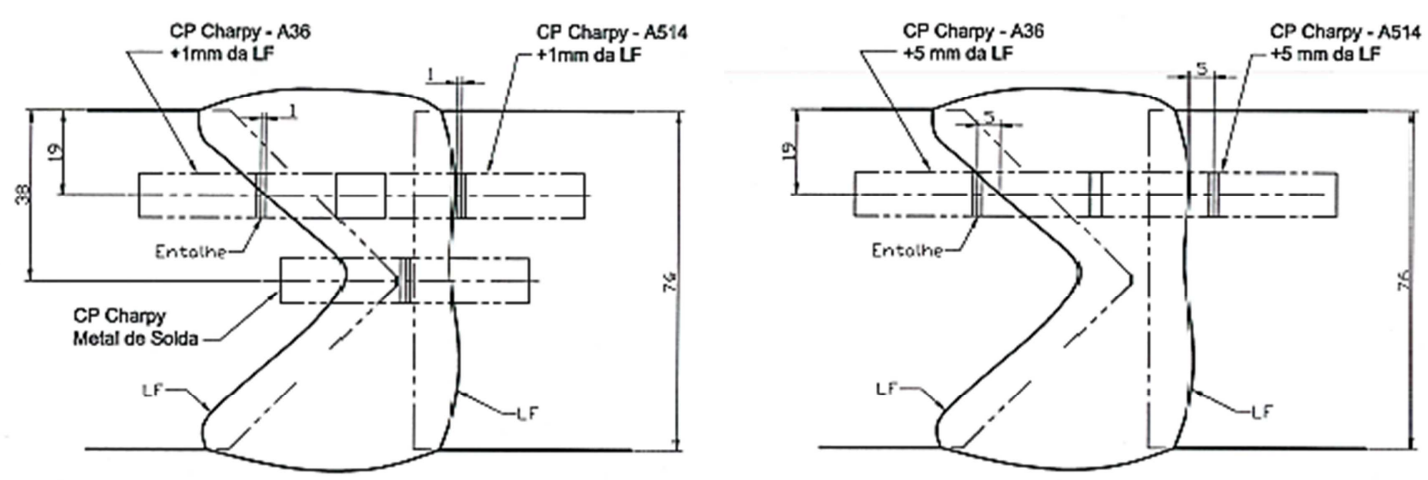

Figura 33 - Locais de remoção dos corpos de prova para ensaio de impacto Charpy, conforme 4.40 da norma AWS D1.1/D1.1M:2010.

No ensaio de impacto Charpy, além da tenacidade também foram medidos a expansão lateral e a porcentagem de fratura dúctil de cada corpo de prova sendo a primeira medida com o auxílio de um micrômetro, enquanto que a segunda foi 
determinada pela observação da superfície fratura com base em padrões de comparação. Tanto a medição da expansão lateral quanto a porcentagem de fratura dúctil seguiram os requisitos estabelecidos pela norma ASTM A370 [52].

A análise da fratura foi realizada, por meio de microscópio eletrônico de varredura - MEV nas faces fraturadas das amostras do ensaio Charpy removidos na raiz da solda.

Os corpos de prova para as micrografias foram removidos nas regiões indicadas na Figura 33. Na Figura 34 são mostrados os locais de remoção e as denominações atribuídas, a saber: Região A (LF do A36 x MS), Região B (LF do A514 x MS) e Região C (MS)

A preparação micrográfica consistiu no embutimento a quente com resina termofixa (baquelite), lixamento com lixas d'água (as mesmas granulometrias empregadas na macrografia), polimento com pastas de diamante (com granulometria de 9 , 3 e $1 \mu \mathrm{m}$ ) e ataque com Nital $2 \%$, Picral e LePera modificado (1\% metabissulfito de sódio $+2 \%$ ácido pícrico) onde aplicável.

A identificação dos microconstituintes foi baseada no documento IX-1533-88 do IIW - Instituto Internacional de Soldagem, apud [23].

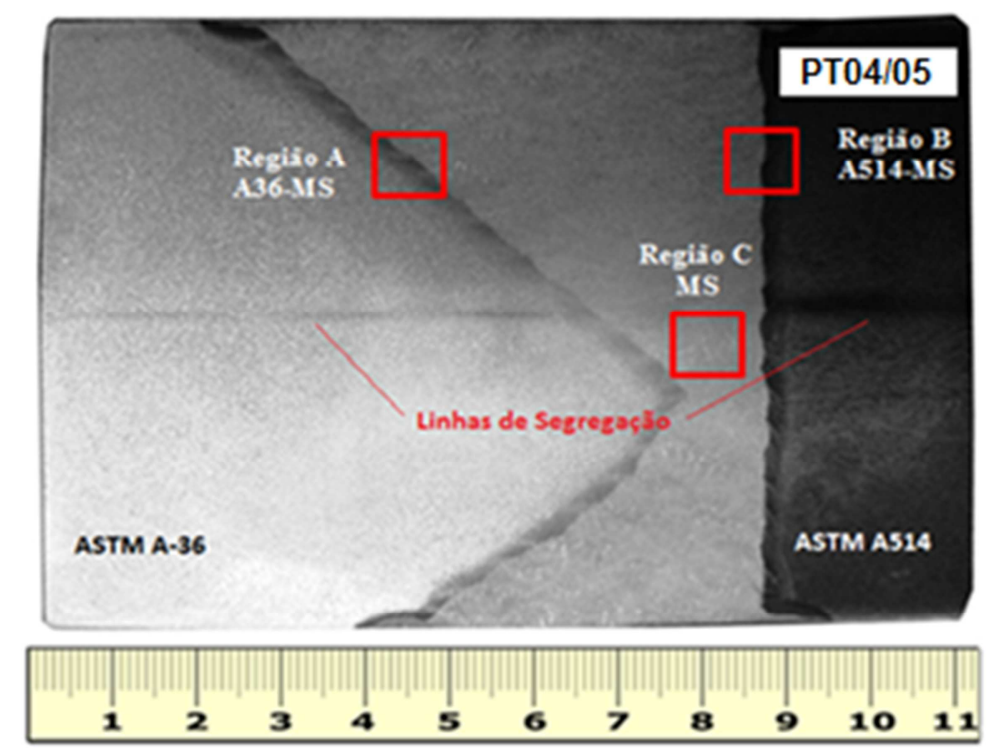

Figura 34 - Locais de remoção dos corpos de prova para micrografia.

Em caráter complementar, foram realizados também análise química por espectrometria de emissão óptica na raiz do metal de solda e MEV/EDS ${ }^{14}$ em carbonetos encontrados no metal de solda após TTAT. As análises foram realizadas no Centro de Ciência e Tecnologia de Materiais (CCTM) do IPEN e na PROAQT.

\footnotetext{
${ }^{14}$ Espectrometria de energia dispersiva de raios $X$
} 


\section{RESULTADOS E DISCUSSÃO}

\subsection{Caracterização do Metal de Base (MB) e do Metal de Adição (MA)}

\subsubsection{Análise da composição química das chapas}

O objetivo principal da análise da composição química das chapas foi a comprovação de que realmente foram recebidas chapas de ASTM A36 e ASTM A514 para a elaboração deste trabalho. Nas Tabelas 14 e 15 são mostrados os resultados obtidos na análise e também os valores declarados pelos certificados.

Tabela 14 - Análise química do produto - Chapa ASTM A36

\begin{tabular}{|c|c|c|c|c|c|c|c|c|c|}
\hline $\begin{array}{l}\text { Elemento } \\
\mathrm{MB}\end{array}$ & C & $\mathrm{Mn}$ & $P$ & S & $\mathrm{Si}$ & $\mathrm{Ni}$ & $\mathrm{Cr}$ & Mo & V \\
\hline $\begin{array}{c}\text { Norma } \\
\text { ASTM A36 }\end{array}$ & $<0,27$ & $\begin{array}{l}0,85 \\
1,20 \\
\end{array}$ & $<0,04$ & $<0,05$ & $\begin{array}{l}0,15 \\
0,40 \\
\end{array}$ & - & - & - & - \\
\hline Produto $^{A}$ & $<0,31$ & $\begin{array}{l}0,77 \\
1,30\end{array}$ & $<0,05$ & $<0,05$ & $\begin{array}{l}0,10 \\
0,45\end{array}$ & - & - & - & - \\
\hline Certificado & 0,17 & 1,11 & 0,019 & 0,014 & 0,23 & - & - & - & - \\
\hline Análise Produto & 0,184 & 1,115 & 0,022 & 0,005 & 0,352 & - & - & - & - \\
\hline$\sigma$ & 0,003 & 0,001 & 0,001 & 0,000 & 0,0005 & - & - & - & - \\
\hline Laudo $^{B}$ & $A$ & $\mathrm{~A}$ & $\mathrm{~A}$ & $\mathrm{~A}$ & $A$ & - & - & - & - \\
\hline
\end{tabular}

Tabela 15 - Análise química do produto - Chapa ASTM A514 grau Q

\begin{tabular}{|c|c|c|c|c|c|c|c|c|c|}
\hline $\begin{array}{l}\text { Elemento } \\
\mathrm{MB}\end{array}$ & C & $\mathrm{Mn}$ & $P$ & $S$ & $\mathrm{Si}$ & $\mathrm{Ni}$ & $\mathrm{Cr}$ & Mo & V \\
\hline Norma A514 & $\begin{array}{l}0,14 \\
0,21\end{array}$ & $\begin{array}{l}0,95 \\
1,30\end{array}$ & $<0,035$ & $<0,035$ & $\begin{array}{l}0,15 \\
0,40\end{array}$ & $\begin{array}{l}1,20 \\
1,50\end{array}$ & $\begin{array}{l}1,00 \\
1,50\end{array}$ & $\begin{array}{l}0,40 \\
0,60\end{array}$ & $\begin{array}{l}0,03 \\
0,08\end{array}$ \\
\hline Norma A6 & $\begin{array}{l}0,11 \\
0,25\end{array}$ & $\begin{array}{l}0,86 \\
1,41\end{array}$ & $<0,045$ & $<0,045$ & $\begin{array}{l}0,10 \\
0,45\end{array}$ & $\begin{array}{l}1,15 \\
1,55\end{array}$ & $\begin{array}{l}0,94 \\
1,56\end{array}$ & $\begin{array}{l}0,36 \\
0,64\end{array}$ & $\begin{array}{l}0,02 \\
0,09\end{array}$ \\
\hline Análise Banho & 0,18 & 1,02 & 0,004 & 0,012 & 0,20 & 1,21 & 1,00 & 0,40 & 0,03 \\
\hline Análise Produto & 0,177 & 1,013 & 0,013 & 0,004 & 0,206 & 1,350 & 0,984 & 0,392 & 0,030 \\
\hline$\sigma$ & 0,001 & 0,004 & 0,000 & 0,000 & 0,000 & 0,001 & 0,0028 & 0,000 & 0,000 \\
\hline Laudo & $A$ & $A$ & $A$ & $A$ & $A$ & $A$ & A & $A$ & $A$ \\
\hline
\end{tabular}

Nos resultados apontados nas Tabelas 14 e 15, nota-se que de um modo geral os valores obtidos nas análises são bastante próximos daqueles declarados nos certificados. É importante salientar que nos certificados de usina a análise química é 
realizada no banho, enquanto que no produto a análise é realizada diretamente na chapa laminada e assim podem haver pequenas variações nos valores cujas tolerâncias para cada elemento são determinadas na Tabela A da norma ASTM A6 [47]. De qualquer modo os resultados obtidos na análise confirmam que as chapas recebidas eram de fato ASTM A36 e ASTM A514 grau Q.

\subsubsection{Determinação da espessura mínima a ser removida das faces oxicortadas}

\subsubsection{Avaliação da macroestrutura}

Na Figura 35 é mostrada a macrografia das peças de testes PT-01 e PT-02 das amostras removidas conforme dimensões da Figura 27.

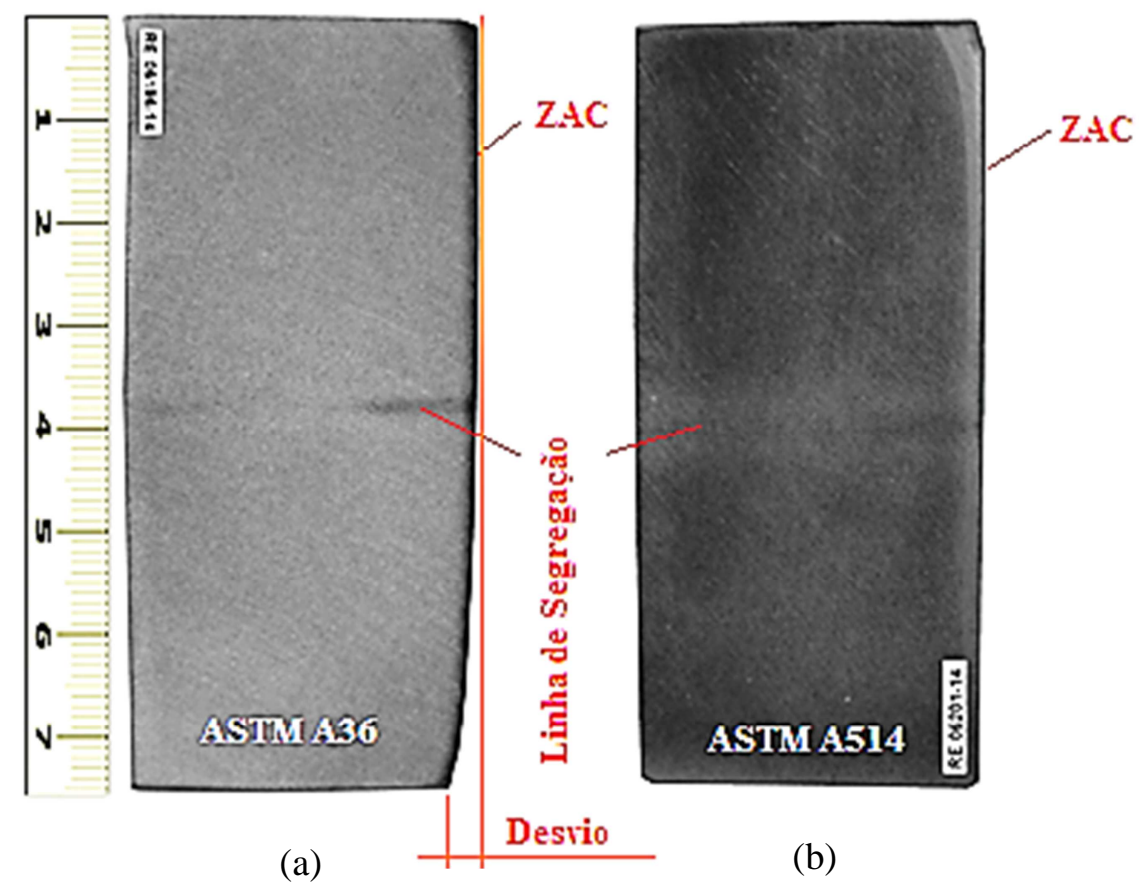

Figura 35 - Macrografias: (a) PT-01 (ASTM A36) e (b) PT-02 (ASTM A514). Ataque: Nital 5\%

Podem ser observadas nas duas macrografias as zonas afetadas pelo calor (ZAC) decorrentes do oxicorte, sendo a ZAC do ASTM A514 revelada com uma tonalidade mais clara, enquanto que a do ASTM A36 mais escura. Nas regiões não afetadas ocorre oposto ${ }^{15}$.

\footnotetext{
${ }^{15}$ Nota-se uma diferença de tonalidade que é devida a melhor capacidade do Nital revelar microestruturas martensíticas do que aquelas com presença de cementita. Deste modo o efeito do ataque no ASTM A514 é mais pronunciado (mais escuro) [50].
} 
Nota-se no corte do ASTM A36 que há um desvio de retilinidade no sentido da espessura do corte, onde a causa provável foi o emprego de um bico de corte com diâmetro maior que o necessário para a espessura da chapa. O desvio é causado pelo grande volume de oxigênio que se expande à medida que 0 jato atravessa a espessura da chapa o que resulta um fundo com largura de sangria superior ao da superfície da chapa [40,42].

Não foram observadas quaisquer descontinuidades na chapa, poros, rechupes, dupla laminação, trincas, exceto as linhas de segregação localizadas no centro da chapa decorrente da redistribuição dos solutos no lingote fundido.

\subsubsection{Avaliação da microestrutura}

Na Figura 36a verifica-se a presença de microestruturas "bandeadas" que são típicas de aços carbono submetido a laminação à quente. O bandeamento no ASTM A36 se manifesta, normalmente, pela formação de "bandas" alternadas de perlita e ferrita. Na Figura 36b um exame próximo à superfície de corte, indica a existência de ferrita de Widmanstätten.

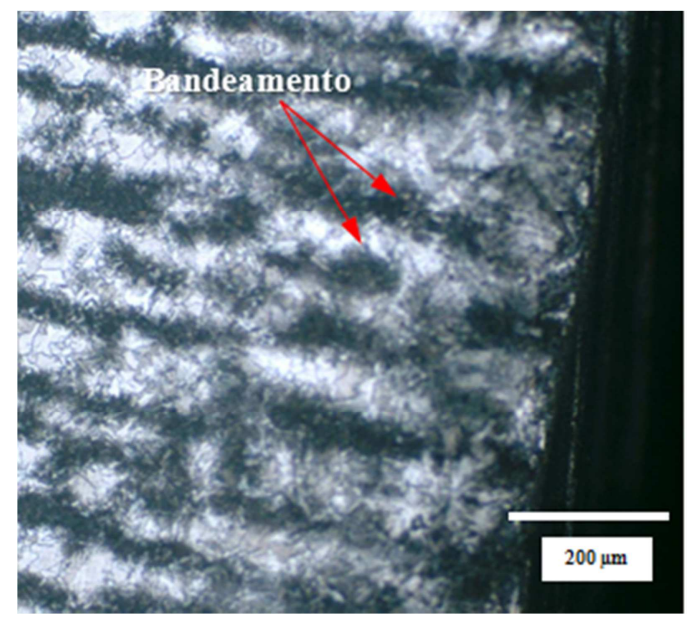

(a)

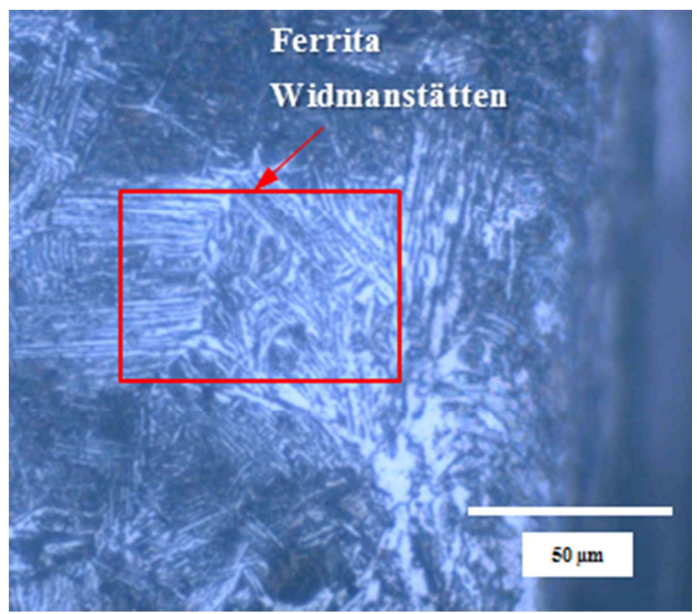

(b)

Figura 36 - (a) e (b) Microestrutura da ZAC, PT-01 (ASTM A36). MO - Ataque: Nital 2\%

A descarbonetação produzida nas operações de oxicorte pode ser definida como um fenômeno cinético, onde o carbono difunde-se em direção à superfície de corte do aço reagindo com o oxigênio de corte ou com os óxidos da escória, reduzindo assim o teor de carbono nas regiões internas adjacentes.

A partir da análise da Figura 37 nota-se na microestrutura do ASTM A514 a existência de uma faixa branca contínua na superfície do corte e outra delgada, 
bastante escura e mais interna, adjacente à branca. Neste caso são regiões respectivamente descarbonetadas e carbonetadas. Por outro lado, na Figura 36 não são observadas tais faixas não podendo ser claramente identificadas, o que levaria a se supor, inicialmente, que não ocorreram tanto a descarbonetação quanto a carbonetação no ASTM A36.

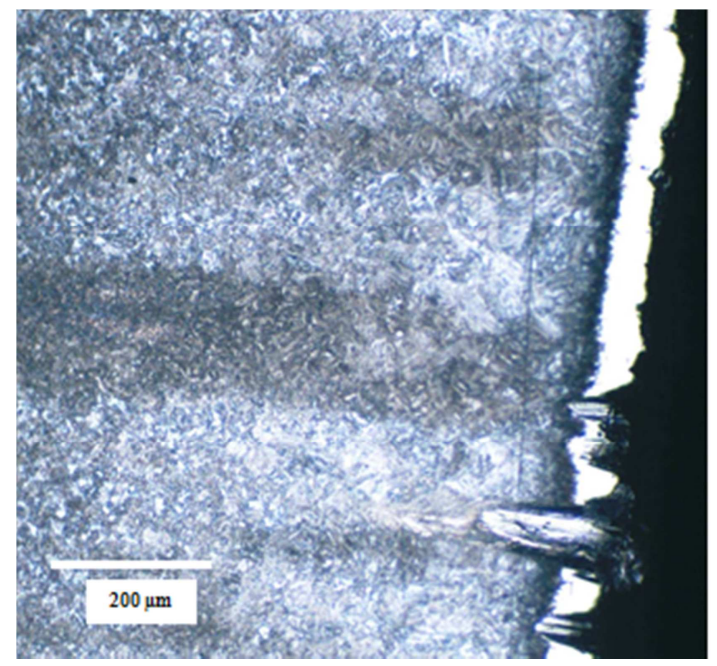

(a)

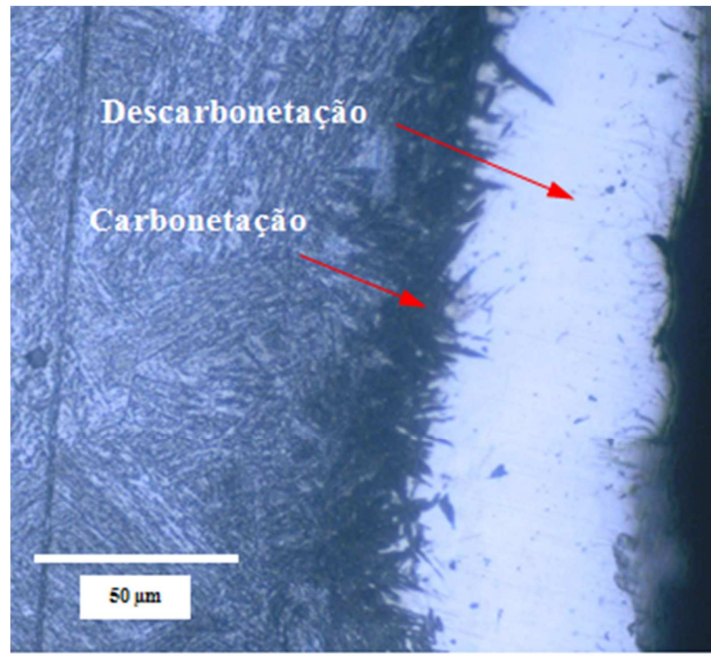

(b)

Figura 37 - (a) e (b) Microestrutura da ZAC, PT-02 (ASTM A514) $\mathrm{MO}$ - Ataque: Nital $2 \%$

Este assunto era um pouco controverso, sendo que Slottman \& Roper [55] na década de 50 do século XX acreditavam que na realidade ocorria apenas a carbonetação das superfícies oxicortadas, quaisquer que fossem as condições de corte e os materiais a serem oxicortados. Entretanto, tal hipótese atualmente não se mostra correta [42,43], visto que quaisquer operações de oxicorte nos aços produzem, em maior ou menor grau, superfícies descarbonetadas e faixas internas carbonetadas.

Nas altas temperaturas o oxigênio reage com o ferro formando $\mathrm{FeO}$, mas também $\mathrm{Fe}_{3} \mathrm{O}_{4}$ e $\mathrm{Fe}_{2} \mathrm{O}_{3}$ sendo, todos esse óxidos imediatamente removidos a medida que avança o corte, enquanto o oxigênio reage com carbono formando $\mathrm{CO}_{2}$ e $\mathrm{CO}$ que são dispersos na atmosfera uma vez que a reação tenha ocorrido. Deste modo, carbono adicional começa a ser retirado do aço dando início a descarbonetação.

Do ponto de vista termodinâmico e cinético, a maior ou menor largura da faixa descarbonetada depende basicamente das variáveis, temperatura e tempo. Durante a operação de oxicorte, a chama apenas aquece a peça até atingir a temperatura de ignição com o oxigênio. A partir deste instante o calor restante é provido pela reação exotérmica que ocorre entre o oxigênio de corte e o ferro. $O$ calor de toda a reação do 
processo consiste da soma do calor da chama e do calor da reação exotérmica. As reações ocorridas no corte são basicamente as seguintes:
$\mathrm{Fe}+1 / 2 \mathrm{O}_{2} \rightarrow \mathrm{FeO}$
$\Delta \mathrm{H}_{1}=\mathrm{q}_{1}$
$[\mathrm{C}]+2[\mathrm{O}] \rightarrow \mathrm{CO}_{2}$
$\Delta \mathrm{H}_{2}=\mathrm{q}_{2}$
$[\mathrm{C}]+[\mathrm{O}] \rightarrow \mathrm{CO}$
$\Delta \mathrm{H}_{3}=\mathrm{q}_{3}$

Enquanto que o calor da chama de pré-aquecimento ${ }^{16}$ é expresso como:

$$
\begin{array}{ll}
\mathrm{C}_{2} \mathrm{H}_{2}+\mathrm{O}_{2} \rightarrow 2 \mathrm{CO}+\mathrm{H}_{2} & \Delta \mathrm{H}_{4}=\mathrm{q}_{4} \\
4 \mathrm{CO}+2 / 3 \mathrm{H}_{2}+\mathrm{O}_{2} \rightarrow 4 / 3 \mathrm{CO}_{2}+2 / 3 \mathrm{H}_{2} \mathrm{O} & \Delta \mathrm{H}_{5}=\mathrm{q}_{5}
\end{array}
$$

O calor total liberado na reação de oxicorte é dado pela soma das Equações 15 a 19:

$Q=q_{1}+q_{2}+q_{3}+q_{4}+q_{5}$

A relação entre o máximo aporte de calor e a máxima temperatura de reação $\left(T_{m}\right)$ é expressa da seguinte forma:

$Q=\int_{298}^{T_{m}} \sum n_{i} C_{p} d T$

Onde $\mathrm{C}_{\mathrm{p}}$ é o calor específico dos produtos à pressão constante, $\mathrm{n}_{\mathrm{i}}$ é a fração molar do componente $i$ no produto.

Como os materiais, ASTM A36 e ASTM A514, foram oxicortados empregandose a mesma velocidade de corte $(240 \mathrm{~mm} / \mathrm{min})$, resta apenas a variável temperatura a ser considerada. Levando-se em conta apenas a equação apresentada é possível que o aporte de calor no oxicorte de aços baixa-liga seja maior o que aumentaria a descarbonetação ${ }^{17}$. Entretanto, muitas outras considerações deveriam ser feitas neste sentido, tais como os teores necessários para que os elementos de liga tenham efeito significativo no corte, determinação da atividade do carbono nos aços baixa-liga, temperatura máxima de reação, condutibilidade térmica do aço, temperatura de pré-

\footnotetext{
${ }^{16}$ Embora o combustível utilizado nos cortes deste trabalho tenha sido o GLP, foi adotado o acetileno nas reações para fins de simplificação.

${ }^{17} \mathrm{Em}$ virtude da maior quantidade de elementos de liga.
} 
aquecimento, para citar alguns [42]. Nota-se, portanto que o assunto é de certo modo complexo e que sua abordagem mais aprofundada fugiria dos propósitos deste trabalho.

A respeito da estreita faixa carbonetada que foi observada na Figura 37 podese dizer que é formada pelo fenômeno de difusão do carbono, favorecido pelas altas temperaturas na região do oxicorte, que ocorre em direção à faixa descarbonetada. Abaixo de $912^{\circ} \mathrm{C}$ o conteúdo de carbono irá diminuir nesta faixa descarbonetada até a formação de uma camada de ferrita continuamente formada a partir da austenita. Abaixo de $727^{\circ} \mathrm{C}$ esta camada de ferrita então atua c omo barreira adicional para a descarbonetação pela a baixa solubilidade do carbono na ferrita, e assim tem-se a formação da faixa carbonetada adjacente [56]. A Figura 38 ilustra de forma esquemática as etapas da formação das faixas descarbonetadas e carbonetadas.
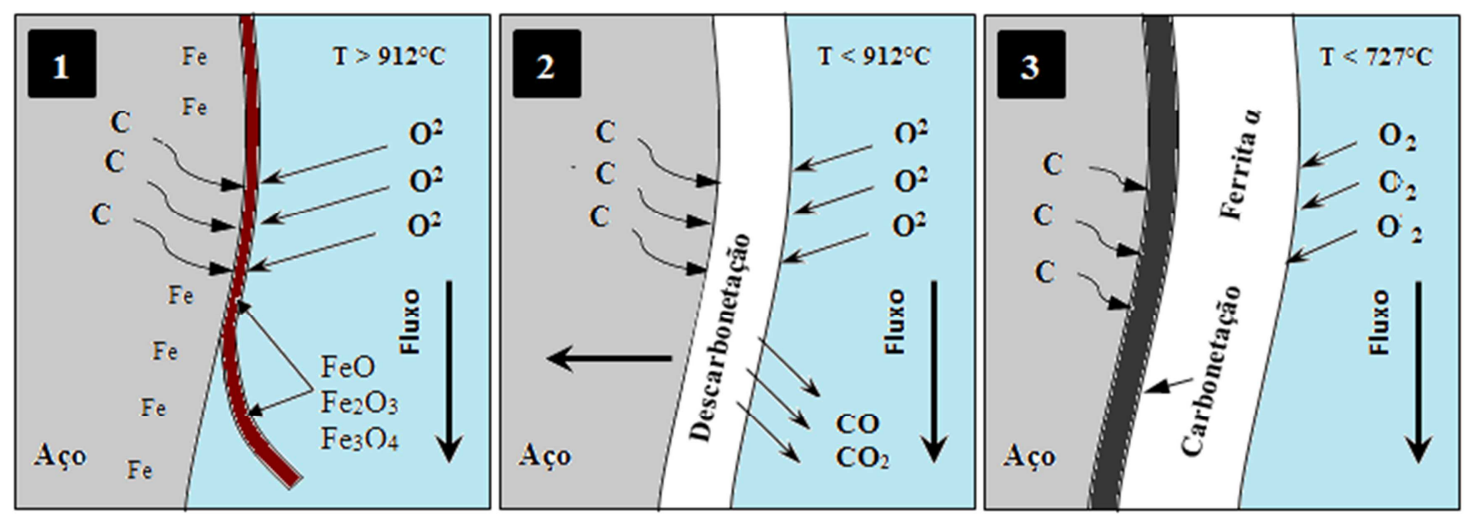

Figura 38 - Formação das faixas carbonetadas e descarbonetadas no oxicorte.

Pode-se notar a existência de pequenas falhas na face oxicortada do ASTM A514, provavelmente decorrentes da presença de elementos de liga refratários. Tais falhas estão indicadas na Figura 37. Embora Glizmanenko [42] tenha afirmado que a presença de elementos de liga só tenha efeito no oxicorte a partir de determinadas concentrações, observa-se na prática que, tais elementos podem ter efeito expressivo no oxicorte, mesmo que as concentrações sejam pequenas, pois cada um dos elementos atua como contaminante e muitas vezes os mesmos não são facilmente oxidados de modo que dificulta a produção do jato de escória [40]. Tipicamente os elementos variam suas concentrações por toda a chapa o que causa uma operação errática no processo de corte. 
Com relação às microestruturas formadas, a análise da Figura 36 mostra a presença de ferrita Widmanstätten formada por transformação displaciva ${ }^{18}$ na região da ZAC do ASTM A36. Por outro lado, no A514 observou-se a formação de martensita, microestrutura já esperada.

\subsubsection{Avaliação da dureza}

Na Figura 39 são mostrados os perfis de durezas obtidos a $1,5 \mathrm{~mm}$ e a $19 \mathrm{~mm}$ da superfície do MB, além do perfil na linha de centro das chapas do ASTM A36 e ASTM A514.

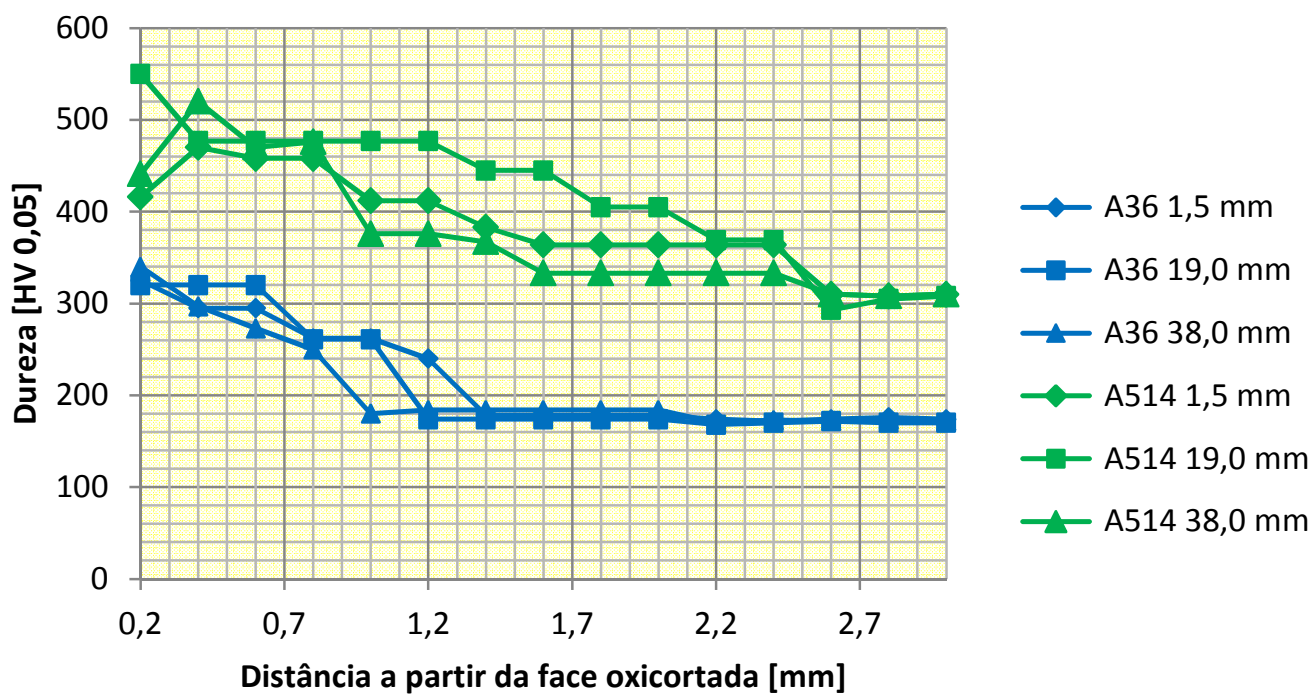

Figura 39 - Perfis de durezas Vickers HV5 PT-01 e PT-02

Pela análise do gráfico nota-se que as durezas foram medidas a partir da cota de 0,2 $\mathrm{mm}$ a contar da face, em virtude da impossibilidade de se medir na cota zero. Sendo assim, não foi possível medir a dureza na região descarbonetada, mas sim a partir da região carbonetada onde se notam picos de dureza para ambos os materiais.

Estes resultados vêm de encontro aos obtidos por Wood [44]. Segundo este autor a concentração de carbono ao longo da aresta oxicortada corresponde a uma fina camada de aproximadamente $0,1 \mathrm{~mm}$ de espessura, sendo que a dureza desta camada é bastante elevada e somente a uma profundidade de $1,5 \mathrm{~mm}$ a contar da face de corte é que a dureza começa a cair até atingir os valores iniciais do metal de

\footnotetext{
${ }^{18}$ A ferrita de Widmanstätten na verdade não é resultante de uma transformação puramente displaciva, mas formada pelo mecanismo de paraequilíbrio envolvendo a rápida difusão do carbono intersticial através da interface da austenita remancescente durante o cisalhamento. [57]
} 
base. Entretanto tal efeito é ainda mais pronunciado no ASTM A514 onde a presença de elementos de liga certamente favorece a formação de regiões endurecidas próximas a face do corte.

\subsubsection{Análise da superfície de corte}

A distribuição do calor pelo oxicorte produzem tensões residuais na região do corte, que somadas aos sulcos produzidos orientados perpendicularmente à direção do corte são altamente desfavoráveis à resistência a fadiga. De forma adicional, as possíveis formações de fases frágeis na ZAC reduzem a tenacidade na região e também favorecem a nucleação e propagação de trincas [42,44].

Diante do exposto é recomendável que a ZAC seja eliminada após o oxicorte, sendo que para alguns tipos de aços tal remoção é mandatória como no caso do ASTM A514 [5,6]. Tal remoção geralmente é feita por meio de esmerilhamento ou fresamento. A princípio pode se deduzir que tal prerrogativa é válida somente para as condições onde as superfícies oxicortadas não são submetidas à soldagem posterior, porém o mesmo cuidado deve ser tomado também para as juntas a serem soldadas, principalmente nas chapas grossas, onde é necessário um grande número de passes. Neste caso, a medida que a soldagem avança novas tensões vão sendo formadas, além das tensões residuais pré-existentes, o que pode propiciar formações de trincas nas regiões de microestruturas frágeis.

Desta forma, assumindo uma postura conservadora neste trabalho, foi removido por fresamento uma espessura de $3,0 \mathrm{~mm}$ da face oxicortada do ASTM A514. Nesta superfície não foram detectadas quaisquer descontinuidades, após ensaio de líquido penetrante. Com isso evita-se que possíveis indicações lineares que porventura ocorressem durante a soldagem da peça de testes fossem decorrentes de problemas anteriores nos metais de base.

\subsubsection{Análise do hidrogênio difusível do consumível}

O objetivo principal da análise do hidrogênio difusível do consumível foi garantir que, o arame tubular empregado neste trabalho contivesse um teor de hidrogênio 
difusível inferior a $4 \mathrm{ml} / 100 \mathrm{~g}$, ou seja, uma designação $\mathrm{H} 4^{19}$ conforme a norma AWS A5.36. Na Tabela $5.3^{20}$ são mostrados os valores obtidos na análise de hidrogênio difusível máximo obtido por cromatografia a gás, conforme a norma AWS A4.3 [45].

Tabela 16 - Análise teor de hidrogênio difusível máximo - Arame tubular E71T-1C

\begin{tabular}{|c|c|c|c|c|c|}
\hline CP n. ${ }^{\circ}$ & $\begin{array}{c}\text { Temperatura } \\
\text { Ambiente } \\
\left({ }^{\circ} \mathrm{C}\right)\end{array}$ & $\begin{array}{c}\text { Umidade } \\
\text { Relativa do } \\
\text { Ar }(\%)\end{array}$ & $\begin{array}{l}\text { Massa do } \\
\text { Depósito } \\
\text { (g) }\end{array}$ & $\begin{array}{l}\text { Tempo } \\
\text { (s) }\end{array}$ & $\begin{array}{l}\text { Hidrogênio } \\
\text { (ml/100g) }\end{array}$ \\
\hline 01 & 21,7 & 59 & 5,5125 & 613 & 4,12 \\
\hline 02 & 21,7 & 59 & 7,5972 & 614 & 2,31 \\
\hline 03 & 21,7 & 60 & 8,4861 & 615 & 3,19 \\
\hline & & & \multirow{2}{*}{\multicolumn{2}{|c|}{$\begin{array}{r}\text { Média } \\
\text { Desvio Padrão }\end{array}$}} & 3,21 \\
\hline & & & & & 0,9 \\
\hline
\end{tabular}

O impacto do teor de hidrogênio difusível é tão significativo que, diversas normas consideram o efeito deste crucial na sanidade de uma junta soldada. A norma EN 1011-2, por exemplo, considera que a forma mais efetiva de se evitar trincas induzidas por hidrogênio é pela redução do hidrogênio, que é adicionado no metal de solda pelo consumível. Os benefícios são tão relevantes que em até alguns casos é possível se soldar sem pré-aquecimento, desde que os teores de hidrogênio no consumível estejam abaixo de determinado valor. Na norma PETROBRAS N-133 por sua vez é indicado que os arames tubulares obedeçam à designação do hidrogênio difusível máximo, conforme a norma AWS A5.36, levando em consideração a tensão mínima nominal de resistência do metal de base. No caso deste trabalho, onde o A514 possui uma tensão de resistência superior a $587 \mathrm{MPa}$ tal designação de consumível é o $\mathrm{H} 4$, ou seja, $4 \mathrm{ml} / 100 \mathrm{~g}$ de metal depositado. Para a norma AWS D1.1 o teor de hidrogênio difusível exerce significativa influência na determinação da temperatura de pré-aquecimento, conforme descrito no item 16.2.2 do ANEXO I da referida norma.

Diante do exposto, pode-se afirmar que o teor de hidrogênio difusível máximo presente no arame tubular empregado na soldagem das peças de testes deste trabalho atende as exigências estabelecidas pelas normas citadas. Portanto, deixa de se constituir uma segunda variável na análise de susceptibilidade de trincamento a frio analisada pelos experimentos utilizados as peças CTS, onde apenas é desejado saber qual a influência da temperatura de pré-aquecimento.

\footnotetext{
${ }^{19}$ A rigor poderia ser empregado neste trabalho um arame tubular com designação de hidrogênio difusível máximo superior a $\mathrm{H} 4$, porém isto iria se tornar uma nova variável na análise das trincas a frio induzidas por hidrogênio onde se preferiu avaliar apenas o efeito da temperatura de pré-aquecimento.

${ }^{20}$ A Tabela 5.3 segue o formato recomendado pela norma AWS A4.3-93 (R2006)
} 


\subsubsection{Determinação da temperatura mínima de preaquecimento}

Das quinze peças de testes soldadas (ver 4.2.1.4), quatro delas apresentaram trincas, a saber: PT-03A-2 (MS e ZAC), PT-03A-3 (ZAC), PT-03A-5 (ZAC) e PT-03B-4 (ZAC).

O sufixo A nas peças de testes indicam que a soldagem foi sem preaquecimento, enquanto que o sufixo $B$ indica um preaquecimento de $110^{\circ} \mathrm{C}$ e 0 sufixo $\mathrm{C}$ um preaquecimento de $160^{\circ} \mathrm{C}$.

Pela análise dos resultados nota-se que das cinco peças de testes soldadas sem preaquecimento ocorreram trincas em três delas. Na prática tal soldagem não seria executada nesta condição ${ }^{21}$, porém esta foi inserida nos ensaios para comprovar os efeitos de uma possível ausência do preaquecimento antes da soldagem. $\mathrm{Na}$ temperatura de $110^{\circ} \mathrm{C}$ houve apenas uma ocorrência de trinca o que mostra os efeitos positivos do aumento da temperatura, porém ainda não garante a sanidade das juntas quanto ao trincamento a frio. Finalmente, a $160^{\circ} \mathrm{C}$ n enhuma ocorrência de trinca foi observada, o que comprova a eficiência da metodologia proposta pelas normas AWS D1.1 e DIN EN 1011-2 para a determinação da temperatura de preaquecimento.

O efeito da aplicação do pré-aquecimento na redução da taxa de resfriamento a partir de $500^{\circ} \mathrm{C}^{22}$ pode ser evidenciado pela aplicação da Equação de Rosenthal para a condição de escoamento do calor tridimensional.

Considerando-se os dados abaixo e, conforme a Equação 9 tem-se que:

$\mathrm{k}=35 \mathrm{~J} / \mathrm{m} . \mathrm{s} \cdot{ }^{\circ} \mathrm{C}$, condutibilidade térmica do aço

$\mathrm{I}=127 \mathrm{~A}$, corrente

$\mathrm{U}=27 \mathrm{~V}$, tensão

$\mathrm{V}=32 \mathrm{~cm} / \mathrm{min}=5,3 \cdot 10^{-3} \mathrm{~m} / \mathrm{s}$, velocidade de soldagem

$\varepsilon=0,85$, eficiência do arco (FCAW) [13]

$\mathrm{T}=300^{\circ} \mathrm{C}^{23}$

Para $\mathrm{T}_{0}=25^{\circ} \mathrm{C}$

\footnotetext{
${ }^{21}$ Até porque é mandatório o pré-aquecimento para juntas de ASTM A514 conforme a norma AWS D1.1

22 A faixa de $800^{\circ} \mathrm{C}$ a $500^{\circ} \mathrm{C}$ representa a faixa conhecida como t $8 / 5$ onde ocorrem as principais transformações metalúrgicas. Assim, a influência do preaquecimento dá-se a partir de $500^{\circ} \mathrm{C}$.

${ }^{23} \mathrm{~A}$ taxa de resfriamento imposta pelo teste nas proximidades da temperatura de $300^{\circ} \mathrm{C}$ é considerada significativa para a formação de trincas quando a taxa crítica é excedida [34].
} 


$$
\begin{aligned}
& \left(\frac{\partial T}{\partial t}\right)_{x}=\left(-2 \pi \cdot 35 \cdot 5,3 \cdot 10^{-3}\right) \cdot \frac{(300-25)^{2}}{0,85 \cdot 127 \cdot 27}=-30^{\circ} \mathrm{C} / \mathrm{s} \\
& \text { Para } \mathrm{T}_{0}=110^{\circ} \mathrm{C} \\
& \left(\frac{\partial T}{\partial t}\right)_{x}=\left(-2 \pi \cdot 35 \cdot 5,3 \cdot 10^{-3}\right) \cdot \frac{(300-110)^{2}}{0,85 \cdot 127 \cdot 27}=-14^{\circ} \mathrm{C} / \mathrm{s} \\
& \quad \text { Para } \mathrm{T}_{0}=160^{\circ} \mathrm{C} \\
& \left(\frac{\partial T}{\partial t}\right)_{x}=\left(-2 \pi \cdot 35 \cdot 5,3 \cdot 10^{-3}\right) \cdot \frac{(300-160)^{2}}{0,85 \cdot 127 \cdot 27}=-8^{\circ} \mathrm{C} / \mathrm{s}
\end{aligned}
$$

Analisando os resultados obtidos nota-se claramente o efeito da aplicação do pré-aquecimento na taxa de resfriamento da junta soldada. Entretanto, é importante frisar que o teste CTS é qualitativo e assim não permite a determinação de taxas de resfriamento crítico para juntas soldadas. Também é importante salientar que o resfriamento não é uma função linear, mas uma função cuja derivada varia para cada temperatura conforme ilustrado na Figura 40. Outro aspecto, também relevante, é que a temperatura de pré-aquecimento necessária para cada espessura varia aproximadamente conforme uma função tangente hiperbólica e assim, a partir de uma determinada espessura (aproximadamente $60 \mathrm{~mm}$ ), a temperatura de préaquecimento atinge um valor próximo do máximo, ou seja, um acréscimo na espessura não implica em um acréscimo significativo na temperatura de préaquecimento conforme ilustrado na Figura 41.

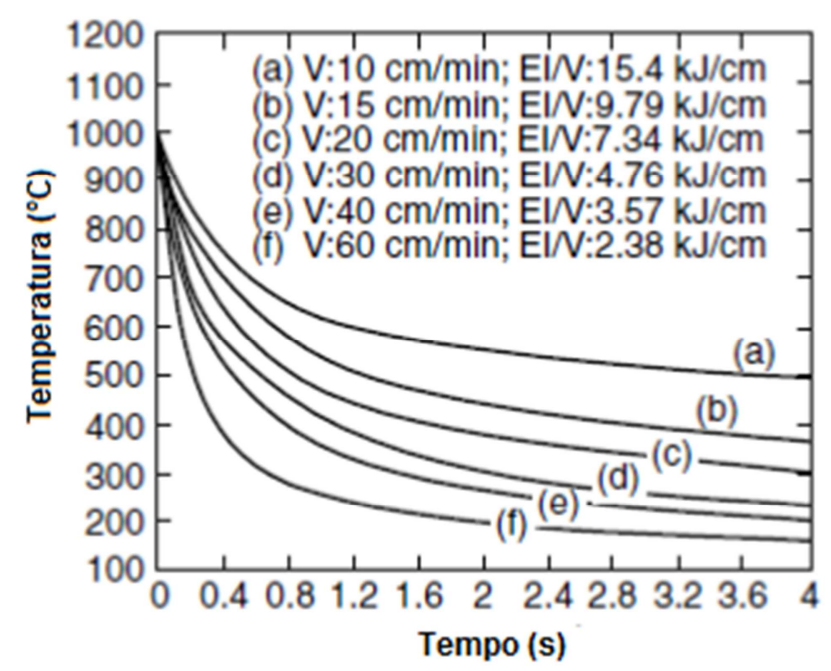

Figura 40 - Variação das taxas de resfriamento com o aporte de calor [15]

Nota-se também, pela análise dos resultados, que todas as trincas ocorreram na solda 3D que é a condição de maior extração de calor, ou seja, a mais severa, o que aumenta a taxa de resfriamento da junta nesta região. 


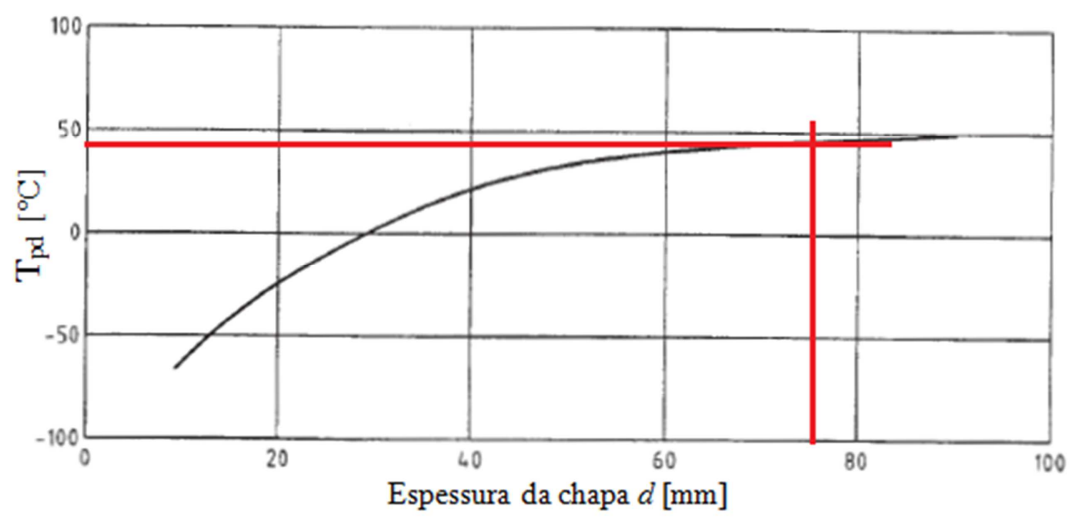

Figura 41 - Temperatura de pré-aquecimento em função da espessura da chapa [26]

A fim de ilustrar a ocorrência das trincas foi escolhida a peça de testes que apresentou trincas, tanto da ZAC, quanto no metal de solda. Na Figura 42 estão apresentadas as descontinuidades observadas na solda 3D da peça de testes PT03A2 detectadas após o ensaio de líquido penetrante.

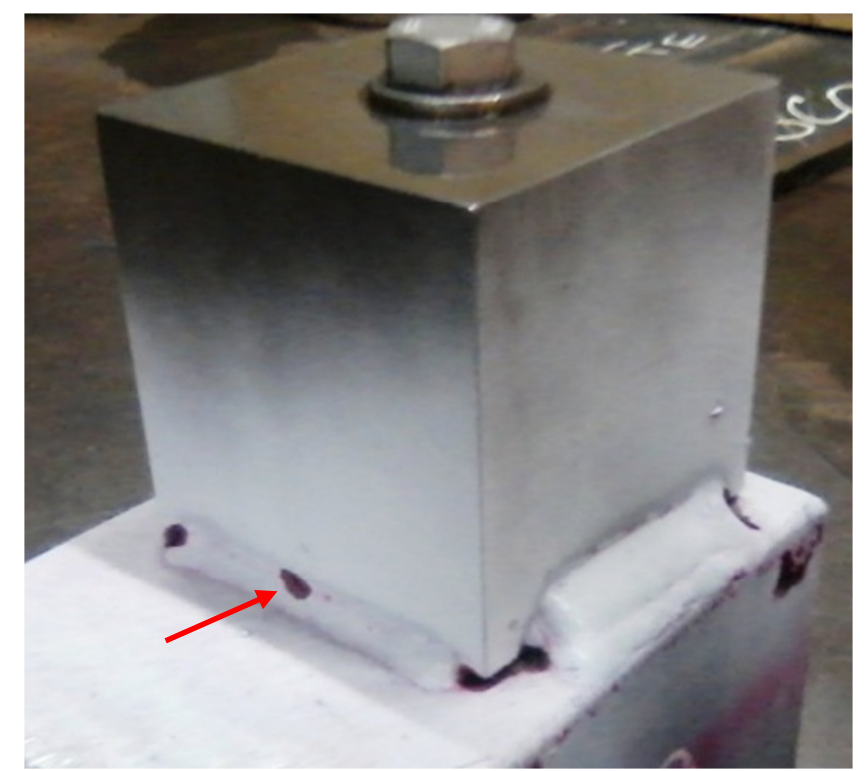

Figura 42 - Indicação linear (trinca) na solda 3D da peça de testes PT-03A2 (CTS) após ensaio de líquido penetrante.

Na Figura 43 é mostrado o corpo de prova extraído da região de ocorrência da trinca para exame macrográfico. Nota-se um intenso manchamento do ataque (tonalidade mais escura) na região da trinca indicando a presença deste defeito.

Pela análise da Figura 44 nota-se que a trinca se originou na região de maior concentração de tensões criada propositalmente pelo rebaixo de $1 \mathrm{~mm}$ usinado na parte de A514 da peça de testes CTS. Nesta figura é mostrado o detalhe ampliado da junta com a localização dos pontos de medição de dureza e também da trinca. 


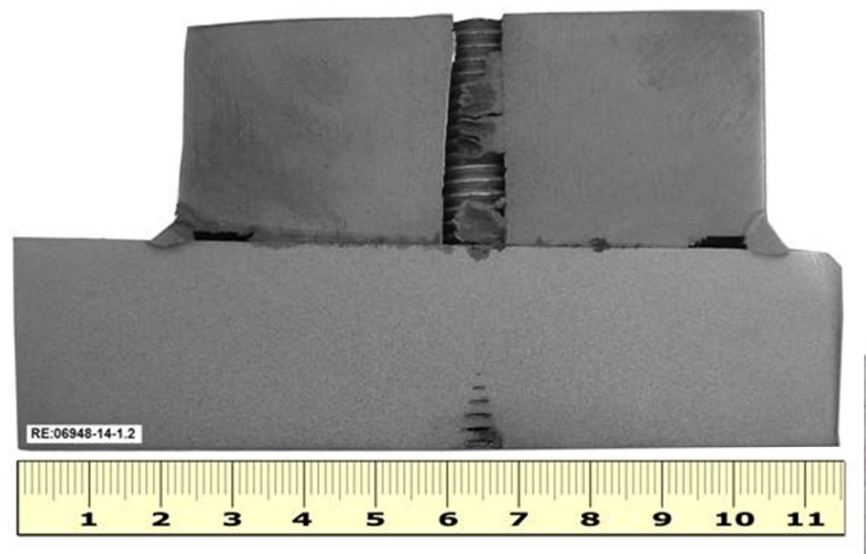

(a)

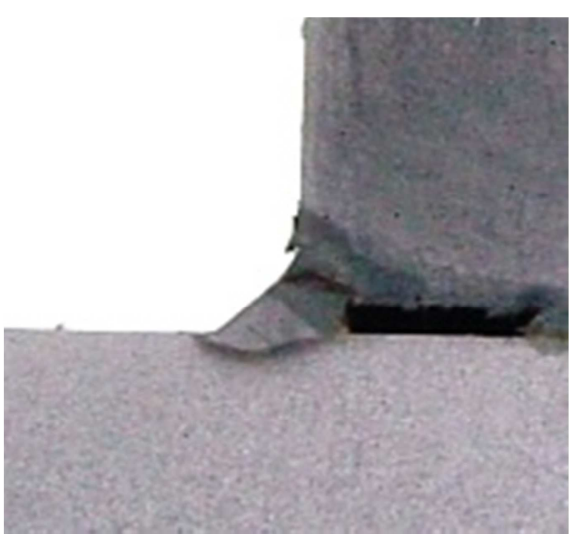

(b)

Figura 43 - Macrografia da peça de testes PT-03A2 (a) e detalhe ampliado da indicação linear (trinca) na ZAC e MS (b)

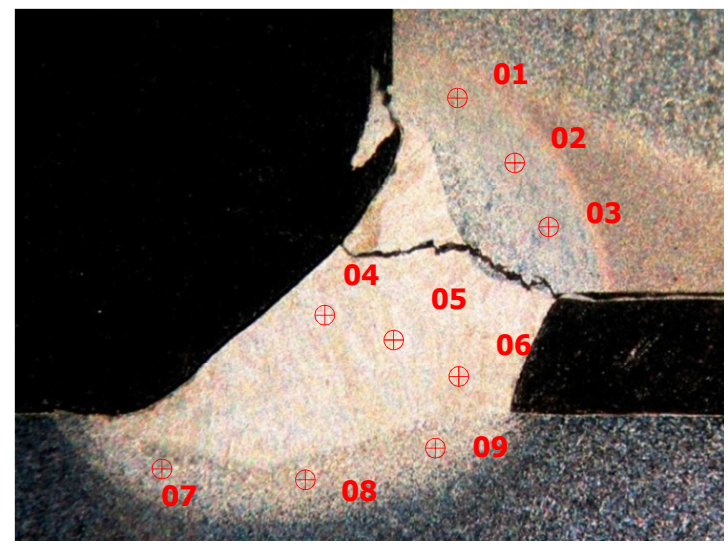

(a)

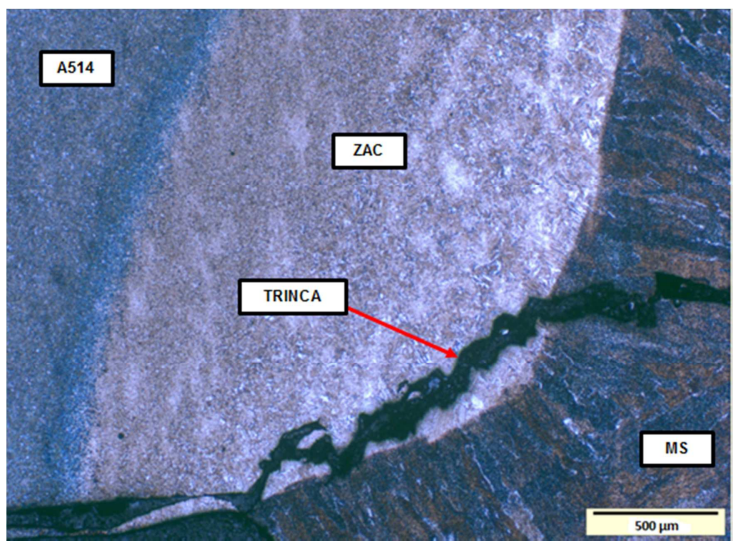

(b)

Figura 44 - (a) Pontos de medição de microdureza na macrografia da peça de testes PT-03A2. (b) Detalhe da indicação linear (trinca) . Aumento 10X - ataque: Nital 2\%

A nucleação da trinca ocorreu na margem da solda na região de crescimento de grãos da ZAC do A514 cuja microestrutura é formada por martensita possivelmente fragilizada pela presença de hidrogênio e, portanto, susceptível ao trincamento, o que vem de encontro com a teoria proposta por Granjon [14] para o trincamento a frio discutido na revisão bibliográfica deste trabalho. Tal condição é ainda mais agravada pela presença de tensões residuais e também pela elevada dureza nas regiões das ZAC's. É possível, por meio de modelos matemáticos, onde se destaca o de Yurioka [58], prever a dureza da ZAC conforme descrito no Anexo E. A Tabela 17 mostra os valores de dureza HV5 medidos nos pontos indicados pela Figura 44.

Nota-se, pela análise da Tabela 17 que os valores previstos na dureza das ZAC's pelo modelo de Yurioka, são razoáveis se comparados aos obtidos na medição 
direta. O cálculo da dureza da ZAC conforme o modelo de Yurioka encontra-se detalhado no Anexo E.

Cabem aqui mais algumas considerações sobre a taxa de resfriamento da junta nas diversas condições de preaquecimento.

A norma DIN EN 1011-2 [31] admite que é possível a soldagem sem necessidade de preaquecimento desde que, certo valor de aporte de calor mínimo seja imposto na junta. Assim foi tomado o devido cuidado para que o cordão fosse executado nas condições de menor aporte de calor possível (baixa corrente e tensão combinada com alta velocidade de soldagem), porém permitindo uma estabilidade de arco necessária para a execução de um cordão de aspecto visual satisfatório (sem descontinuidades).

\begin{tabular}{|c|c|c|c|c|}
\hline Localização & Ponto & $\begin{array}{c}\text { Previsto } \\
\text { Yurioka } \\
\text { (HV5) }\end{array}$ & $\begin{array}{l}\text { Valor } \\
\text { (HV5) }\end{array}$ & $\bar{x} \pm \sigma$ \\
\hline \multirow{3}{*}{ ZAC - A514 } & 01 & \multirow{3}{*}{450} & 443 & \multirow{3}{*}{$440 \pm 5$} \\
\hline & 02 & & 445 & \\
\hline & 03 & & 433 & \\
\hline \multirow{3}{*}{ Metal de Solda } & 04 & \multirow{3}{*}{$\mathrm{N} / \mathrm{A}$} & 321 & \multirow{3}{*}{$312 \pm 6$} \\
\hline & 05 & & 306 & \\
\hline & 06 & & 310 & \\
\hline \multirow{3}{*}{$\mathrm{ZAC}-\mathrm{A} 36$} & 07 & \multirow{3}{*}{366} & 395 & \multirow{3}{*}{$388 \pm 6$} \\
\hline & 08 & & 380 & \\
\hline & 09 & & 390 & \\
\hline
\end{tabular}

Considerando-se que o teor de hidrogênio do consumível empregado foi baixo (< $5 \mathrm{ml} / 100 \mathrm{~g}$ ), conforme destacado neste estudo, os parâmetros de soldagem empregados foram os mesmos para todas as peças de testes, restou apenas a variável temperatura de pré-aquecimento para ser avaliada neste trabalho.

A temperatura de preaquecimento de $160^{\circ} \mathrm{C}$ além de facilitar a difusão do hidrogênio também reduz a taxa de resfriamento da junta soldada o que evita a formação de martensita no membro de ASTM 36 além de reduzir as tensões residuais. 
Deste modo, pode-se afirmar que a temperatura de $160^{\circ} \mathrm{C}$ é adequada para a soldagem da junta ASTM A514 X ASTM A36 empregando-se baixos aportes de calor ${ }^{24}$ desde que seja respeitado o teor máximo de hidrogênio difusível.

\subsection{Preparação e qualificação da soldagem}

\subsubsection{Ensaios Não Destrutivos - END}

Para fins de qualificação de procedimento de soldagem (EPS) conforme a norma AWS D1.1, é exigido antes da preparação dos corpos de prova para os ensaios mecânicos, a execução de ensaios não destrutivos, a saber: superficial (visual - item 4.9.1) e volumétrico (ultrassom ou radiográfico - item 4.9.2).

Neste trabalho optou-se por complementar o exame visual com o ensaio por líquido penetrante. Com relação ao exame volumétrico a opção foi pelo exame por ultrassom.

A exigência da norma AWS D1.1 [5] a respeito do intervalo mínimo de 48 horas depois de concluída a soldagem para a realização dos END foi rigorosamente obedecida, visto que trincas a frio podem ocorrer mesmo 48 horas após a soldagem da junta $[5,6,14]$.

Os ensaios não destrutivos foram realizados nas peças de testes antes e após o TTAT, onde aplicável, e não foram detectadas indicações relevantes ou quaisquer indicações de trincas. Assim, as peças de testes foram aprovadas permitindo a posterior remoção dos corpos de prova para a execução dos ensaios mecânicos.

\subsubsection{Ensaios destrutivos}

Para esta aplicação, conforme a norma AWS D1.1, estão previstos, além dos ensaios END, apenas o ensaio de tração e de dobramento, e em alguns casos, os exames macrográficos ${ }^{25}$. Quaisquer outros ensaios complementares, tais como dureza, impacto Charpy, entre outros, devem estar previstos em contrato entre o fornecedor e o cliente ${ }^{26}$.

\footnotetext{
${ }^{24}$ Como foram empregados parâmetros de soldagem cujos valores foram os menores possíveis para se obter um cordão aceitável, fica evidente que quaisquer outros parâmetros produzirão um aporte de calor maior, o que é uma condição favorável visto que a taxa de resfriamento será menor.

${ }^{25}$ Conforme item 4.11.3 da norma AWS D1.1 para a qualificação de juntas PJP - Partial Joint Penetration (Juntas de Penetração Parcial), e também para juntas tubulares em T-, Y- ou K- conforme item 4.13.

${ }^{26}$ Conforme item 4.2.1.3 da norma AWS D1.1
} 


\subsubsection{Ensaios de tração}

$\mathrm{Na}$ Tabela 18 são apresentados os resultados obtidos nos ensaios de tração de seção reduzida.

Tabela 18 - Valores de ensaio de tração- PT-04 (CS) e PT-05 (TTAT)

\begin{tabular}{c|c|c|c|c|c|c|c|c}
\hline $\begin{array}{c}\text { Corpo } \\
\text { de } \\
\text { Prova }\end{array}$ & \multicolumn{2}{|c|}{$\begin{array}{c}\text { Secção } \\
{\left[\mathrm{mm}^{2}\right]}\end{array}$} & \multicolumn{2}{c|}{$\begin{array}{c}\text { Carga } \\
{[\mathrm{kgf}]}\end{array}$} & \multicolumn{2}{c|}{$\begin{array}{c}\text { LR } \\
{[\mathrm{MPa}]}\end{array}$} & \multicolumn{2}{c}{ Local Ruptura } \\
\hline & PT-04 & PT-05 & PT-04 & PT-05 & PT-04 & PT-05 & PT-04 & PT-05 \\
\hline TP1.1 & 659,06 & 643,22 & 34580 & 31930 & 515 & 487 & A36 & A36 \\
\hline TP1.2 & 655,20 & 646,15 & 34980 & 32200 & 524 & 489 & A36 & A36 \\
\hline TP2.1 & 651,05 & 647,13 & 34140 & 32270 & 514 & 489 & A36 & A36 \\
\hline TP2.2 & 656,36 & 646,03 & 34910 & 32370 & 522 & 491 & A36 & A36 \\
\hline \multicolumn{7}{c}{} & \multicolumn{3}{c}{$\bar{x} \pm \sigma$} & $519 \pm 5,0$ & $489 \pm 1,6$ & &
\end{tabular}

$\mathrm{Na}$ Figura 45 é mostrado um gráfico contendo os valores de limite de resistência (LR) obtidos após o ensaio de tração. Apenas o valor de LR deve ser medido, embora também seja possível a medição do limite de escoamento, alongamento e redução de área, sendo estes dois últimos apenas a título informativo, pois a existência de diferentes regiões (MS, ZAC, MB) com propriedades mecânicas diferentes tornam estas medidas pouco confiáveis e com baixa acuracidade [59].

A ruptura de todos os corpos de prova ocorreu no metal de base ASTM A36, o que era de se esperar visto que o LR do A36 é inferior ao do ASTM A514 e inferior também ao valor do metal de solda. O metal de solda em geral contém uma alta densidade de discordâncias que também contribui para aumentar a tensão de escoamento nos aços carbono-manganês. O resultado final é que o metal de solda normalmente possui maiores limites de escoamento e de resistência do que o metal de base, mesmo quando o conteúdo de carbono e/ou elementos de liga é inferior [15]. 


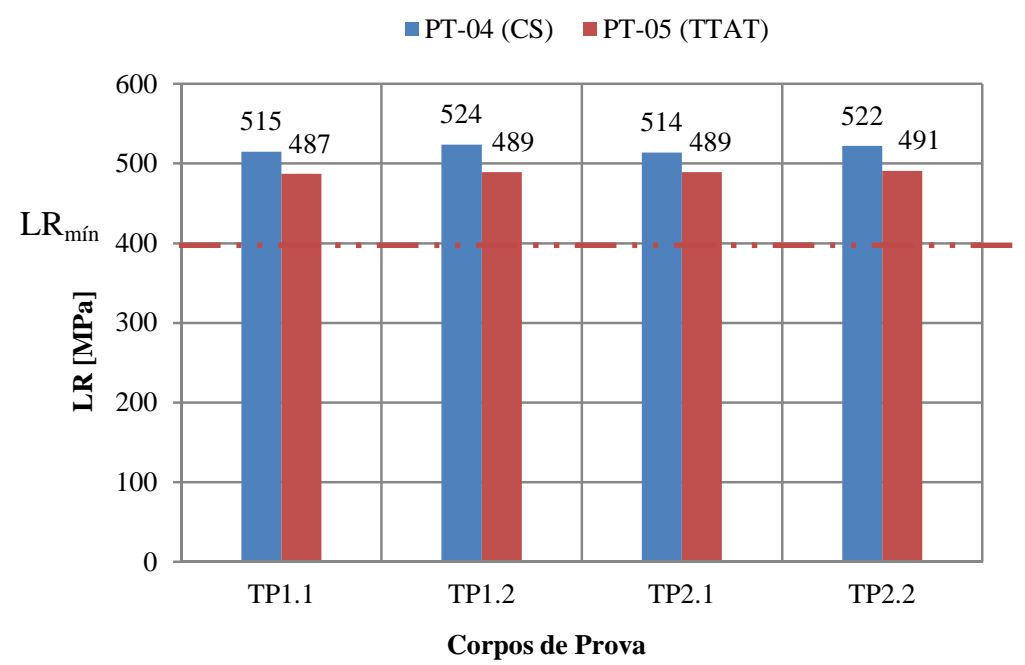

Figura 45 - Gráfico comparativo dos limites de resistência dos corpos de prova removidos das peças de teste PT-04 (s/TT) e PT-05 (c/TT) após ensaio de tração

Os valores de LR obtidos nos corpos de prova da PT-05 (TTAT) mostram o efeito do tratamento térmico na redução da resistência mecânica (vide Anexo F). Para a condição do tratamento térmico realizado, o Parâmetro de Hollomon assume um valor de $\mathrm{H}=18,2$, a partir da Figura 1 do anexo observa-se uma redução de 5\% aproximadamente, no valor do LR. Portanto, o valor médio de LR obtido para o corpos de prova da PT-04 foi de 519 MPa e, considerando-se esta redução de $5 \%$ é de se prever um valor do LR de 493 MPa para a condição após TTAT . O valor médio obtido para os corpos de prova da PT-05 foi de $489 \mathrm{MPa}$, ou seja uma variação inferior a 1\%, em relação ao valor teórico a partir de $\mathrm{H}$. O parâmetro $\mathrm{H}$ possibilita combinar diversos ciclos de TTAT, que podem provocar efeitos similares nas propriedades mecânicas da junta. Portanto, pode-se prever a influência nos limites de resistência e escoamento da junta soldada a partir do parâmetro $\mathrm{H}$ desde que a ruptura ocorra no metal de base $[36,37]$.

Na Figura 46 é mostrado o aspecto dos corpos de prova após o ensaio de tração e também o aspecto da fratura. Pela análise da fratura nota-se o contorno superficial característico conhecido por taça-cone onde a região central interior possui uma aparência irregular e fibrosa, indicativa de deformação plástica o que caracteriza uma fratura dúctil [60].

O parágrafo 4.9.3.5 da norma AWS D1.1 estabelece que o critério de aceitação para o ensaio de tração é o valor mínimo da tensão de resistência do metal de base, no caso de uma junta ASTM A36 x ASTM A514, tal valor mínimo a ser considerado é o limite de resistência do ASTM A36 de $400 \mathrm{MPa}$. O item 4.9.5 da referida norma 
estabelece que caso algum dos corpos de prova não atinja esse valor mínimo, dois novos corpos de prova devem ser preparados e ensaiados a título de reteste.

Com base nestas premissas e de acordo com os valores obtidos nos ensaios de tração pode-se concluir que todos os corpos de prova foram aprovados no ensaio de tração com base na norma AWS D1.1.

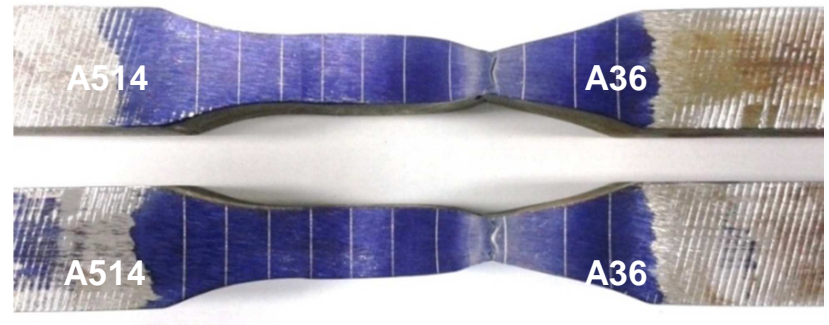

(a)
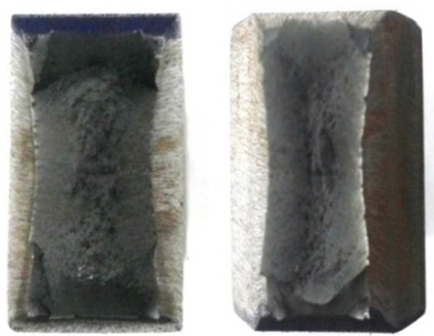

(b)

Figura 46 - (a) Aspecto dos corpos de prova após ensaio de tração e (b) superfície de fratura.

\subsubsection{Ensaios de dobramento lateral}

$\mathrm{Na}$ Tabela 19 são mostrados os resultados obtidos nos ensaios de dobramento lateral (DL).

Tabela 19 - Ensaio de Dobramento Lateral - PT-04 (CS) e PT-05 (TTAT)

\begin{tabular}{c|c|c|l}
\hline \multirow{2}{*}{$\begin{array}{c}\text { Corpo } \\
\text { de } \\
\text { Prova }\end{array}$} & $\begin{array}{c}\text { Dimensões } \\
{[\mathrm{mm}]}\end{array}$ & \multicolumn{2}{|c}{ Resultados } \\
\cline { 3 - 4 } & PL-04 & \multicolumn{1}{|c}{ PT-05 } \\
\hline DL 01 & $10 \times 77 \times 300$ & Isento de descontinuidades & Isento de descontinuidades \\
\hline DL 02 & $10 \times 77 \times 300$ & Isento de descontinuidades & Isento de descontinuidades \\
\hline DL 03 & $10 \times 77 \times 300$ & Isento de descontinuidades & Isento de descontinuidades \\
\hline DL 04 & $10 \times 77 \times 300$ & Isento de descontinuidades & 01 Abertura de 1,0 mm no MS \\
\hline
\end{tabular}

Na Figura 47 é mostrado o detalhe ampliado da indicação ocorrida no corpo de prova DL04.

Os quatro corpos de prova submetidos ao ensaio de dobramento não mostraram quaisquer descontinuidades na região de interface entre $M B$, ZAC e MS após o ensaio. Os resultados obtidos nos ensaios evidenciaram que houve perfeita fusão e boa ductilidade sendo, portanto aprovados com base em inspeção visual da junta soldada. 


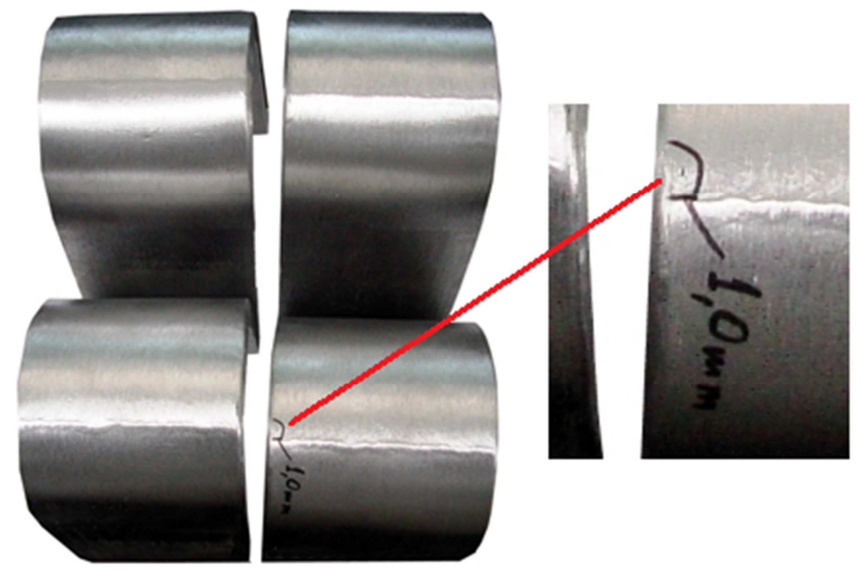

Figura 47 - Detalhe da descontinuidade encontrada no metal de solda após ensaio de dobramento lateral no corpo de prova DL04/PT-05.

\subsubsection{Macrografia}

A Figura 48 mostra o aspecto da macrografia da junta em "K". O exame macrográfico revelou uma solda isenta de porosidades, inclusões de escória, falta de fusão e trincas atendendo, portanto os critérios de aceitação estabelecidos pela norma AWS D1.1 no item 4.9.4.1.

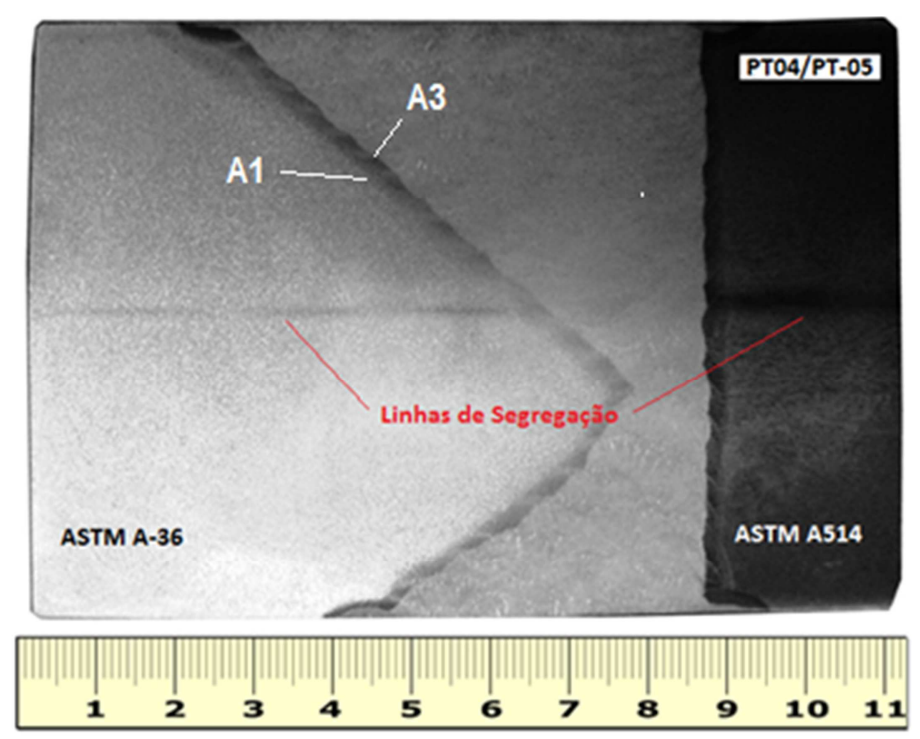

Figura 48 - Macrografia da peça de testes PT-04 destacando as linhas de segregação. Ataque: Nital $5 \%$

Na macrografia é possível observar as linhas de segregação, no centro da Figura 48, para ambos os materiais, fenômeno típico na laminação de chapas grossas. Nas ZAC's é possível notar uma variação progressiva da coloração onde se pode 
distinguir a região onde a temperatura excede a temperatura $A 1$ e a região totalmente austenitizada pelo aquecimento acima da linha A3.

\subsubsection{Considerações finais sobre a qualificação da soldagem}

Com base nos resultados obtidos pelos ensaios END, destrutivos (tração e dobramento e macrográfico), pode-se concluir que é possível a qualificação de um procedimento de soldagem (EPS) conforme a norma AWS D1.1, para a junta especificada e empregando-se os parâmetros de soldagem propostos para ambas as condições: sem e com tratamento térmico de alívio de tensões. É importante salientar, porém que tal procedimento não contempla requisitos suplementares, tal como o de tenacidade, sendo nesse ultimo caso necessário a complementação de ensaios conforme contrato entre o fornecedor e o cliente.

\subsection{Caracterização da junta soldada}

\subsubsection{Dureza}

$\mathrm{Na}$ Tabela 20 são mostrados os valores obtidos de dureza conforme o perfil mostrado na Figura 32 para as peças de testes PT-04 e PT-05 nas condições "como soldado" e após TTAT respectivamente.

Tabela 20 - Perfil de Durezas - PT-04 (CS) e PT-05 (TTAT). Valores medidos em HV5.

\begin{tabular}{|c|c|c|c|c|c|c|c|c|c|}
\hline & \multirow{2}{*}{ Região } & \multicolumn{4}{|c|}{ PT-04 (CS) } & \multicolumn{4}{|c|}{ PT-05 (TTAT) } \\
\hline & & P1 & $\mathrm{P} 2$ & P3 & $\bar{x} \pm \sigma$ & P1 & P2 & P3 & $\bar{x} \pm \sigma$ \\
\hline \multirow{5}{*}{$\begin{array}{l}\overline{\mathbf{I}} \\
\underline{\mathbf{I}} \\
\underline{\Xi}\end{array}$} & MB (A36) & 154 & 158 & 152 & $155 \pm 2$ & 147 & 150 & 149 & $149 \pm 1$ \\
\hline & ZAC (A36) & 273 & 257 & 237 & $256 \pm 15$ & 178 & 183 & 186 & $182 \pm 3$ \\
\hline & MS & 217 & 212 & 220 & $216 \pm 3$ & 212 & 243 & 209 & $221 \pm 15$ \\
\hline & ZAC (A514) & 413 & 418 & 400 & $410 \pm 8$ & 284 & 266 & 263 & $271 \pm 9$ \\
\hline & MB (A514) & 252 & 248 & 250 & $250 \pm 2$ & 248 & 256 & 251 & $252 \pm 3$ \\
\hline \multirow{5}{*}{$\begin{array}{l}= \\
\text { 志 } \\
\underline{\underline{z}}\end{array}$} & MB (A36) & 151 & 148 & 148 & $149 \pm 1$ & 142 & 136 & 145 & $141 \pm 4$ \\
\hline & ZAC (A36) & 190 & 197 & 199 & $195 \pm 4$ & 172 & 172 & 162 & $169 \pm 5$ \\
\hline & MS & 213 & 264 & 208 & $228 \pm 25$ & 215 & 220 & 210 & $215 \pm 4$ \\
\hline & ZAC (A514) & 303 & 329 & 346 & $326 \pm 18$ & 251 & 280 & 256 & $262 \pm 13$ \\
\hline & MB (A514) & 266 & 257 & 260 & $261 \pm 4$ & 245 & 253 & 250 & $249 \pm 3$ \\
\hline \multirow{5}{*}{$\begin{array}{l}\equiv \\
\text { 采 } \\
\underline{Z} \\
\underline{\Xi}\end{array}$} & MB (A36) & 150 & 155 & 148 & $151 \pm 3$ & 143 & 145 & 143 & $144 \pm 1$ \\
\hline & ZAC (A36) & 270 & 268 & 283 & $274 \pm 7$ & 156 & 161 & 157 & $158 \pm 2$ \\
\hline & MS & 207 & 233 & 217 & $219 \pm 11$ & 214 & 196 & 224 & $211 \pm 12$ \\
\hline & ZAC (A514) & 424 & 414 & 414 & $417 \pm 5$ & 280 & 276 & 279 & $278 \pm 2$ \\
\hline & MB (A514) & 252 & 250 & 249 & $250 \pm 1$ & 232 & 227 & 235 & $231 \pm 3$ \\
\hline
\end{tabular}


A média dos valores obtidos foram plotados em dois gráficos conforme mostrado nas Figuras 49 e 50.

Pela análise da Tabela 20 e da Figura 49 nota-se a existência de picos de dureza e grandes diferenças entre as linhas de medição (I,II,III) na PT-04 (CS) enquanto que para a peça PT-05 (TTAT) nota-se uma maior uniformidade dos valores. Observa-se apenas uma elevação gradativa de dureza atingindo o valor máximo na ZAC do A514, o que era de se esperar pela existência de uma microestrutura martensítica. Nota-se que os valores de dureza da linha II foram menores aos outros em virtude desta linha se localizar na raiz da solda e esta estar sujeita aos efeitos de revenimento da soldagem multipasse. Entretanto, nesta mesma linha II o valor medido de 264 HV sugere a formação de algum microconstituinte de dureza mais elevada ${ }^{27}$, visto que os outros valores medidos foram de 208 e $213 \mathrm{HV}$.

O maior efeito do tratamento térmico deu-se nas zonas afetadas pelo calor tanto do A36 quanto do A514 como pode ser observado nas figuras. A queda nos valores de dureza foi menos acentuada em ambos os metais de base como também no metal de solda, o que mostra que estas microestruturas foram menos susceptíveis aos efeitos do tratamento térmico. A redução na dureza do A514 também não foi muito significativa, mesmo sendo a temperatura de patamar do TTAT $\left(600^{\circ} \mathrm{C}\right)$ ser apenas um pouco inferior a temperatura de revenimento da chapa original $\left(625^{\circ} \mathrm{C}\right)$.

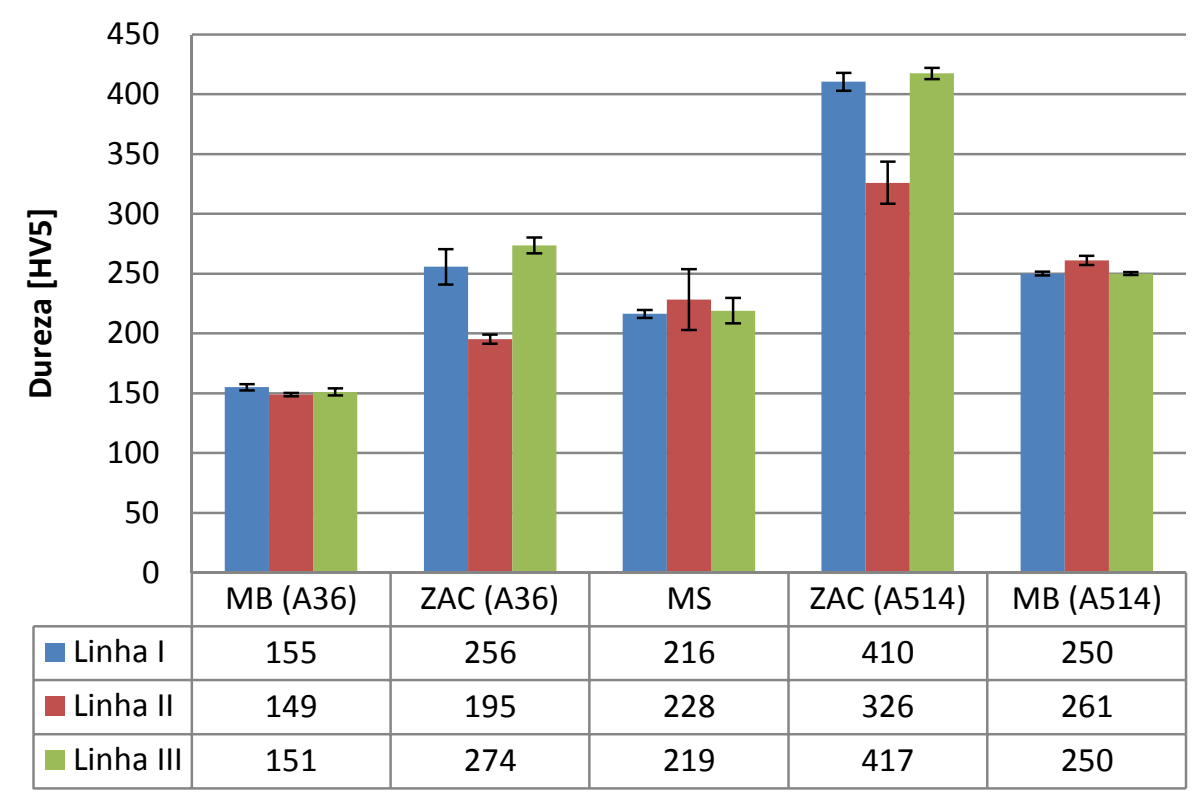

\footnotetext{
27 A princípio pensou-se em se tratar de algum erro de medição e assim outras medidas foram aleatoriamente tomadas na mesma região onde foi constatada a existência de outros pontos de maior dureza. Porém apenas o valor de $264 \mathrm{HV}$ foi reportado por estar contido na mesma linha de medição dos valores de 208 e $213 \mathrm{HV}$.
} 
Figura 49 - Gráfico comparativo dos perfis de dureza medidos na peça de testes PT-04 (CS). Valores médios em HV5

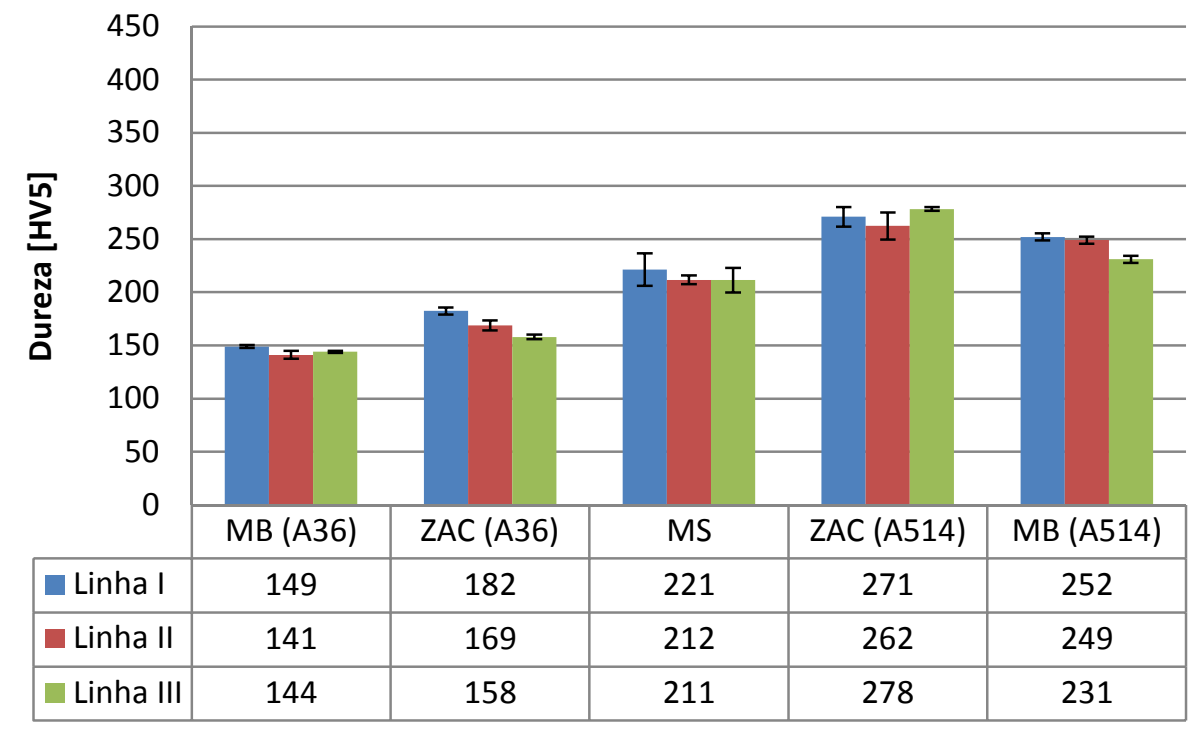

Figura 50 - Gráfico comparativo dos perfis de dureza medidos na peça de testes PT-05 (TTAT). Valores médios em HV5

\subsubsection{Tenacidade da junta}

$\mathrm{Na}$ Tabela 21 são mostrados os valores de energia absorvida obtidos nos ensaios de impacto Charpy para as peças de testes PT-04 e PT-05 nas condições "como soldado" e após TTAT respectivamente.

Tabela 21 - Valores de energia absorvida Ensaio Charpy (-20) - PT-04 (CS) e PT-05 (TTAT)

\begin{tabular}{c|c|c|c|c|c}
\hline \multirow{2}{*}{ Localização } & Peça de & \multicolumn{4}{|c}{ Valores Encontrados em J } \\
\cline { 2 - 6 } & Teste & CP 1 & CP 2 & CP 3 & $\bar{x} \pm \sigma$ \\
\hline $\begin{array}{c}\text { Centro } \\
\text { MS }\end{array}$ & CS & 23 & 36 & 31 & $30 \pm 5$ \\
\cline { 2 - 6 } & TTAT & 11 & 16 & 10 & $12 \pm 3$ \\
\hline $\begin{array}{c}\text { ZAC } 1 \mathrm{~mm} \\
\text { LF A36 }\end{array}$ & CS & 124 & 123 & 118 & $122 \pm 3$ \\
\cline { 2 - 6 } & TTAT & 131 & 124 & 118 & $124 \pm 5$ \\
\hline $\begin{array}{c}\text { ZAC 5 mm } \\
\text { LF A36 }\end{array}$ & CS & 27 & 28 & 51 & $35 \pm 11$ \\
\cline { 2 - 6 } & TTAT & 129 & 70 & 87 & $95 \pm 25$ \\
\hline $\begin{array}{c}\text { ZAC } 1 \mathrm{~mm} \\
\text { LF A514 }\end{array}$ & CS & 60 & 51 & 121 & $77 \pm 31$ \\
\cline { 2 - 6 } $\begin{array}{c}\text { ZAC 5 mm } \\
\text { LF A514 }\end{array}$ & TTAT & 83 & 99 & 36 & $73 \pm 27$ \\
\cline { 2 - 6 } & CS & 191 & 179 & 180 & $183 \pm 5$ \\
\hline
\end{tabular}

$\mathrm{Na}$ Figura 51 é mostrado um gráfico comparativo dos valores médios de energia absorvida pelos corpos de prova removidos das peças de testes PT-04 (CS) e PT-05 (TTAT) após ensaio de impacto Charpy a -20C. 
A norma AWS D1.1 estabelece que os requisitos de impacto para qualificação de procedimentos de soldagem aplicam-se somente quando especificados em documentos de contrato. Caso sejam aplicáveis, os valores mínimos especificados de 27J para a média e de 20J para valores individuais são válidos apenas, para materiais de base cuja tensão mínima de escoamento seja de $345 \mathrm{MPa}$ ou menos. Considerando-se que a tensão de escoamento mínima do ASTM A36 é de 250 MPa e que para o ASTM A514 é de $620 \mathrm{MPa}$, pode-se assumir que os valores mínimos de propriedades mecânicas para esta junta devem ter como referência o ASTM A36. Assim, pode-se dizer, com base nos resultados apresentados na Tabela 21 que os valores de impacto na condição após TTAT não atendem a norma, pois o valor médio de tenacidade para o metal de solda é de $12 \mathrm{~J}$, abaixo do mínimo especificado que é 27J.

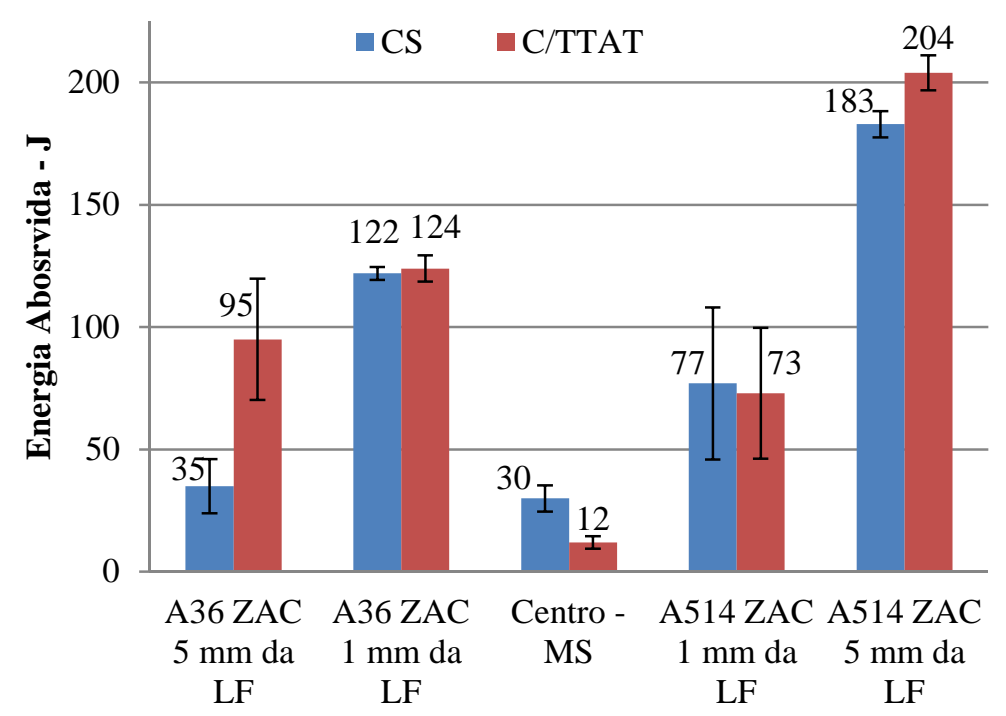

Figura 51 - Gráfico comparativo dos valores de energia absorvida pelos corpos de prova removidos das peças de testes PT-04 (CS) e PT-05 (TTAT) após ensaio de impacto Charpy a $-20^{\circ} \mathrm{C}$.

Pela análise dos resultados obtidos, e levando-se em consideração os respectivos desvios padrão, nota-se que o TTAT atuou beneficamente no sentido de aumentar a tenacidade da junta principalmente na região da ZAC do A36 a $5 \mathrm{~mm}$ da linha de fusão. Nas demais regiões das ZAC's o TTAT não promoveu alterações relevantes quanto à tenacidade e no MS produziu um efeito deletério.

A respeito dos valores de tenacidade encontrados cabem aqui algumas considerações preliminares. O posicionamento do entalhe do corpo de prova na ZAC mostra-se problemático, visto que, na região da linha de fusão existe uma grande variedade de microestruturas que abrange o metal de solda e o metal de base. Assim, um entalhe posicionado na linha de fusão de um chanfro em "V" cobre ao mesmo 
tempo uma porção de metal de solda e de base o que promove a principio, um significativo desvio em torno de um valor médio. Se as propriedades de impacto precisam ser determinadas em regiões específicas da ZAC, então um chanfro em "meio V" ou em "K" é recomendado.

Neste trabalho, o chanfro utilizado foi em "K" sendo a parte reta destinada ao ASTM A514 em razão das advertências da norma AWS D1.1. sobre a ZAC deste material após a soldagem. Entretanto, pela análise da Tabela 21 nota-se que ao contrário do esperado, os maiores desvios ocorreram justamente na ZAC do ASTM A514 em virtude de algumas ocorrências discutidas mais adiante. Outra observação é que os menores valores de impacto na ZAC são encontrados próximos à linha de fusão onde ocorre o crescimento de grão. Microestruturas grosseiras geralmente apresentam baixos valores de tenacidade e por este motivo o aporte de calor precisa ser controlado.

Pela análise da Tabela 21 observa-se que de fato isto ocorre no ASTM A514, porém o mesmo não acontece com o ASTM A36 onde justamente na linha de fusão há valores de tenacidade maiores que a $5 \mathrm{~mm}$ da LF. O ASTM A36 apresentou a $5 \mathrm{~mm}$ da linha de fusão um valor de 35J na condição "como soldado" possivelmente por sofrer os efeitos da região intercrítica. Outra consideração muito importante diz respeito aos baixos valores de tenacidade encontrados no metal de solda. A norma AWS D1.1 estabelece que o corpo de prova deve ser posicionado exatamente na raiz da junta onde os efeitos da diluição com o metal de base são os mais significativos. Como os teores de carbono nos metais de base são superiores aos do metal de adição, é de se esperar um teor de carbono na região da raiz maior que no enchimento. Cabe lembrar que a temperatura de transição é aumentada em torno de $1^{\circ} \mathrm{C}$ para cada acréscimo de $0,1 \%$ no teor de carbono [60]. De fato, os valores de tenacidade encontrados na raiz foram os menores da junta soldada.

$\mathrm{Na}$ Tabela 22 são mostrados os valores medidos de expansão lateral nos corpos de prova de impacto Charpy.

A expansão lateral mede a ductilidade do corpo de prova. A norma AWS D1.1 estabelece que tal requisito, quando necessário deve ser previsto no contrato. Assume-se neste trabalho que tal avaliação não é mandatória e assim, os valores apresentados na Tabela 22 são ilustrativos, mas de qualquer modo eles indicam onde ocorreram fraturas dúcteis e frágeis.

Na Figura 52 é mostrado um gráfico comparativo dos valores de expansão lateral encontrados. Pela análise do gráfico nota-se uma tendência similar aos resultados obtidos de energia absorvida. 
Tabela 22 - Valores de expansão lateral Ensaio Charpy (-20C) - PT-04 (CS) e PT-05 (TTAT)

\begin{tabular}{c|c|c|c|c|c}
\hline \multirow{2}{*}{ Localização } & Peça de & \multicolumn{4}{|c}{ Expansão Lateral [mm] } \\
\cline { 2 - 6 } & Testes & CP 1 & CP 2 & CP 3 & $\bar{x} \pm \sigma$ \\
\hline Centro & CS & 0,50 & 0,56 & 0,55 & $0,54 \pm 0,03$ \\
\cline { 2 - 6 } MS & TTAT & 0,20 & 0,32 & 0,21 & $0,24 \pm 0,07$ \\
\hline \multirow{2}{*}{$\begin{array}{c}\text { ZAC } 1 \mathrm{~mm} \\
\text { LF A36 }\end{array}$} & CS & 1,98 & 2,06 & 1,88 & $1,97 \pm 0,09$ \\
\cline { 2 - 6 } & TTAT & 2,31 & 2,19 & 2,11 & $2,20 \pm 0,10$ \\
\hline $\begin{array}{c}\text { ZAC 5 mm } \\
\text { LF A36 }\end{array}$ & CS & 0,67 & 0,62 & 1,01 & $0,77 \pm 0,21$ \\
\cline { 2 - 6 } & TTAT & 2,23 & 1,31 & 1,59 & $1,71 \pm 0,47$ \\
\hline ZAC 1 mm & CS & 0,87 & 0,71 & 1,72 & $1,10 \pm 0,54$ \\
\cline { 2 - 5 } LF A514 & TTAT & 1,18 & 1,40 & 0,59 & $1,06 \pm 0,42$ \\
\hline ZAC 5 mm & CS & 2,22 & 2,09 & 2,07 & $2,13 \pm 0,08$ \\
\cline { 2 - 5 } LF A514 & TTAT & 2,24 & 2,31 & 2,20 & $2,25 \pm 0,06$ \\
\hline
\end{tabular}

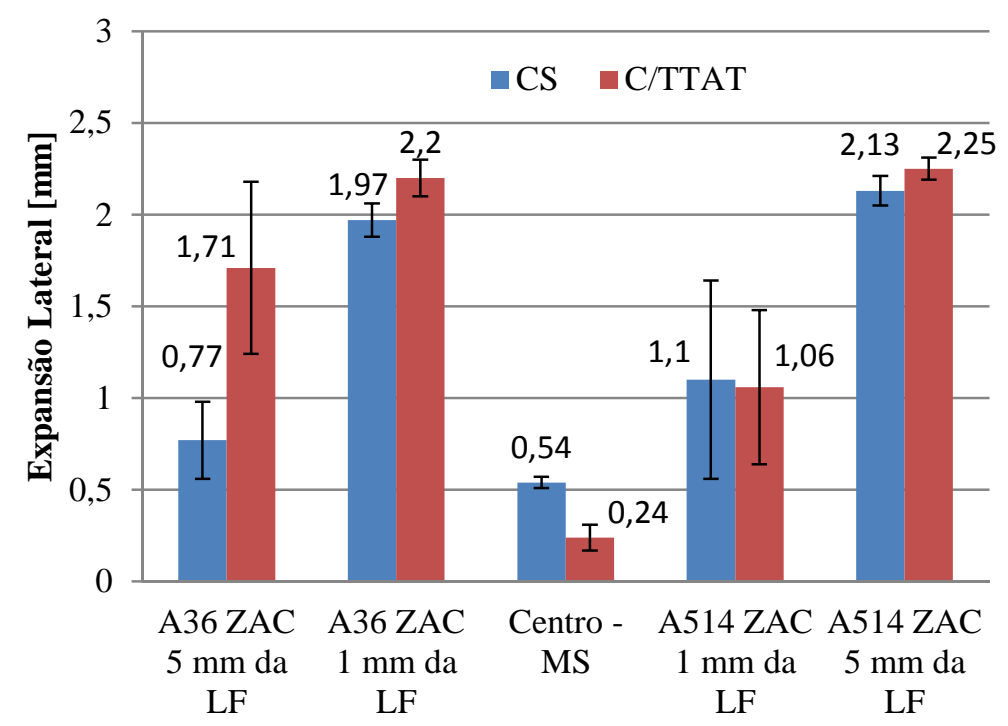

Figura 52 - Gráfico comparativo dos valores de expansão lateral medidos nos corpos de prova removidos das peças de testes PT-04 (CS) e PT-05 (TTAT) após ensaio de impacto Charpy a $-20{ }^{\circ} \mathrm{C}$

\subsubsection{Fractografia}

Nas Figuras 53, 54 e 55 podem ser observados os aspectos das fraturas ocorridas nos corpos de prova, com a indicação do respectivo valor de energia absorvida. 


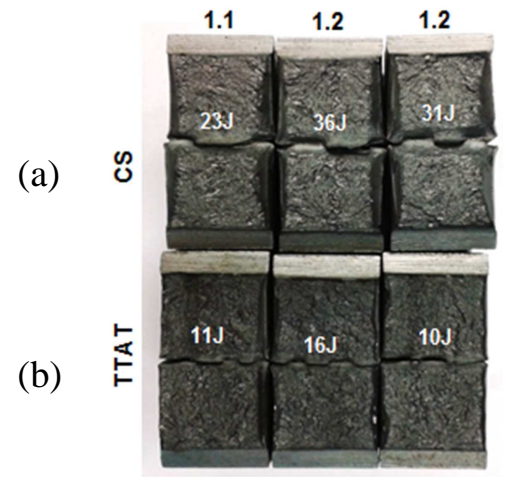

Figura 53 - Aspecto da fratura dos corpos de prova do ensaio de impacto Charpy a $-20^{\circ} \mathrm{C}$ nas (a) condição CS e (b) TTAT - Metal de Solda

(a)
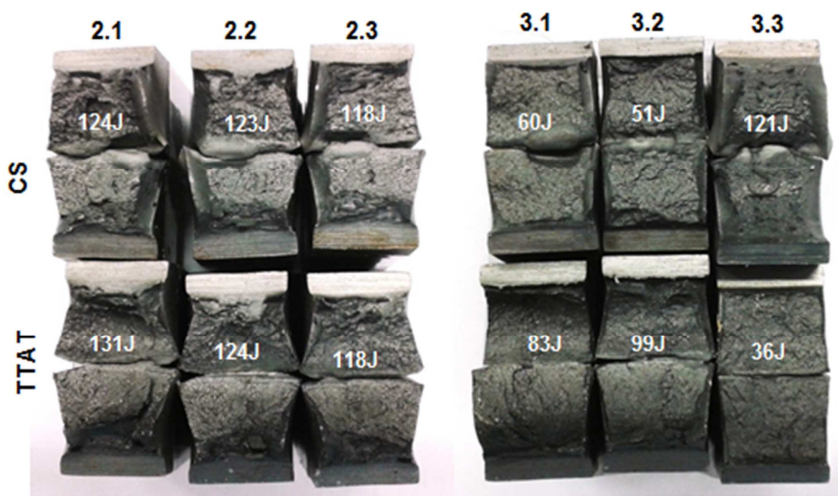

Figura 54 - Aspecto da fratura dos corpos de prova do ensaio de impacto Charpy a $-20^{\circ} \mathrm{C}$ nas condição (a) CS e (b) TTAT - ZAC a 1 mm da LF A36 (2.1 a 2.3) e ZAC a 1 mm da LF A514 (3.1 a 3.3)

(a)
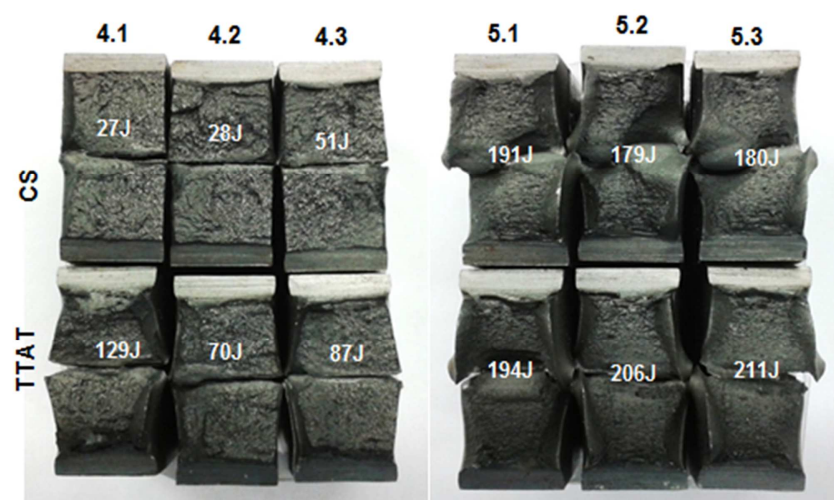

Figura 55 - Aspecto da fratura dos corpos de prova do ensaio de impacto Charpy a $-20{ }^{\circ} \mathrm{C}$ nas (a) condição CS e (b) TTAT - ZAC a 5 mm da LF A36 (4.1 a 4.3) e ZAC a 5 mm da LF A514 (5.1 a 5.3)

A aparência da superfície de fratura fornece informações a respeito do tipo de fratura ocorrido: dúctil ou frágil. A fratura frágil mostra uma superfície brilhante e cristalina com pouca deformação plástica, enquanto que a dúctil uma superfície opaca e fibrosa, com maior deformação plástica na superfície da fratura. 
A porcentagem de fratura dúctil mede a quantidade de fratura dúctil determinada por meio da observação da superfície da fratura com base em padrões de comparação estabelecidos por uma norma, no caso presente a ASTM A370 [52]. $\mathrm{Na}$ Tabela 23 são mostrados os valores de fratura dúctil observados nos corpos de prova ensaiados.

Tabela 23 - Porcentagem de fratura dúctil Ensaio Charpy (-20) - PT-04 (CS) e PT-05 (TTAT)

\begin{tabular}{c|c|c|c|c|c}
\hline \multirow{2}{*}{ Localização } & Peça de & \multicolumn{4}{|c}{ Fratura Dúctil [\%] } \\
\cline { 3 - 6 } & Testes & CP 1 & CP 2 & CP 3 & $\bar{x} \pm$ S \\
\hline Centro & CS & 20 & 30 & 25 & $25 \pm 5$ \\
\cline { 2 - 6 } MS & TTAT & 10 & 10 & 10 & $10 \pm 0$ \\
\hline \multirow{2}{*}{$\begin{array}{c}\text { ZAC 1 mm } \\
\text { LF A36 }\end{array}$} & CS & 60 & 60 & 55 & $58 \pm 3$ \\
\cline { 2 - 6 } & TTAT & 60 & 60 & 60 & $60 \pm 0$ \\
\hline $\begin{array}{c}\text { ZAC 5 mm } \\
\text { LF A36 }\end{array}$ & CS & 20 & 20 & 30 & $23 \pm 6$ \\
\cline { 2 - 6 } & TTAT & 60 & 40 & 40 & $47 \pm 12$ \\
\hline $\begin{array}{c}\text { ZAC 1 mm } \\
\text { LF A514 }\end{array}$ & CS & 45 & 40 & 90 & $58 \pm 28$ \\
\cline { 2 - 6 } & TTAT & 45 & 50 & 20 & $38 \pm 16$ \\
\hline $\begin{array}{c}\text { ZAC 5 mm } \\
\text { LF A514 }\end{array}$ & CS & 100 & 100 & 100 & $100 \pm 0$ \\
\cline { 2 - 6 } & TTAT & 100 & 100 & 100 & $100 \pm 0$ \\
\hline
\end{tabular}

A porcentagem de fratura dúctil é um indicativo da tenacidade do corpo de prova sendo que a norma AWS D1.1 estabelece que tal requisito, quando necessário deve ser previsto no contrato.

A Figura 56 mostra um gráfico comparativo dos valores de fratura dúctil encontrados.

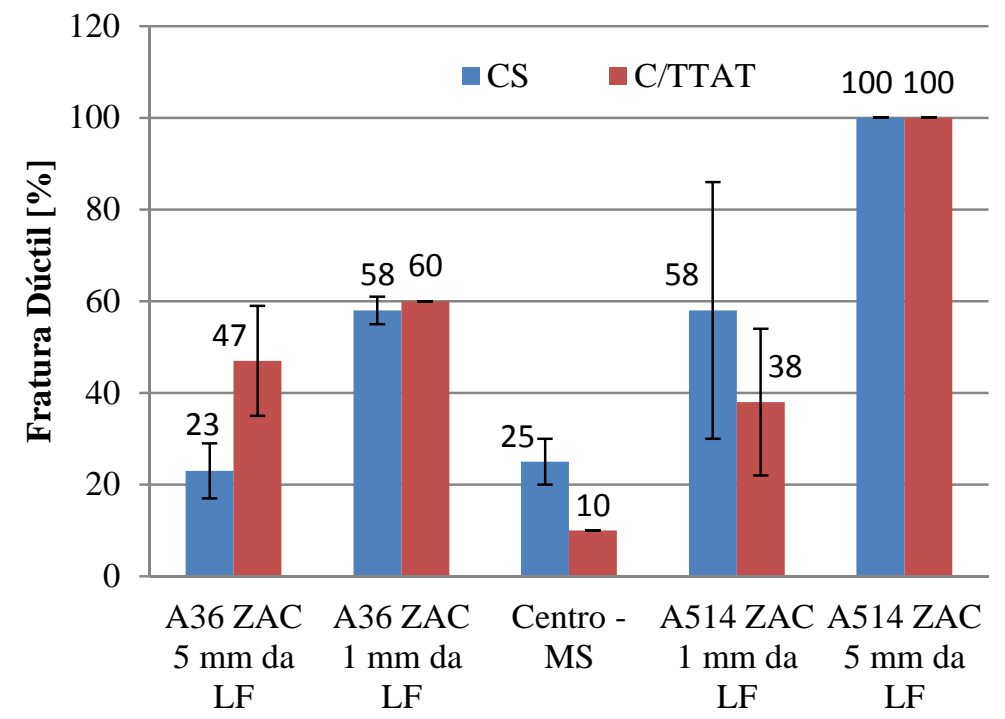

Figura 56 - Gráfico comparativo dos valores de fratura dúctil medidos nos corpos de prova removidos das peças de testes PT-04 (CS) e PT-05 (TTAT) após ensaio de impacto Charpy a $-20^{\circ} \mathrm{C}$ 
De qualquer modo, para uma análise mais apurada dos mecanismos de fratura torna-se necessário um exame de fractografia mais minucioso. Com o auxilio do microscópio de varredura eletrônica é possível determinar o mecanismo da fratura ocorrida: dúctil, frágil ou a combinação dos dois. Isto é importante, pois a comprovação de fratura frágil em determinada condição pode indicar a existência de microconstituintes frágeis naquela região do material.

As Figuras 57 e 58 mostram o aspecto da fratura de um corpo de prova Charpy removido na região da raiz do metal de solda.

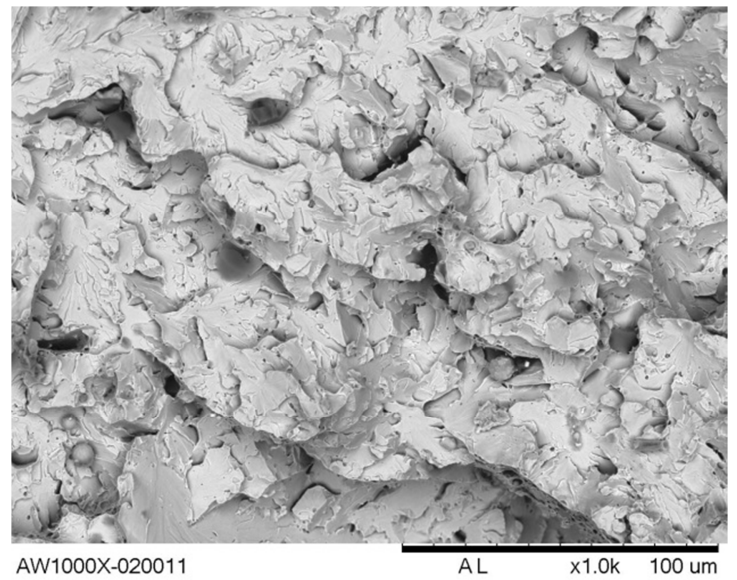

(a)

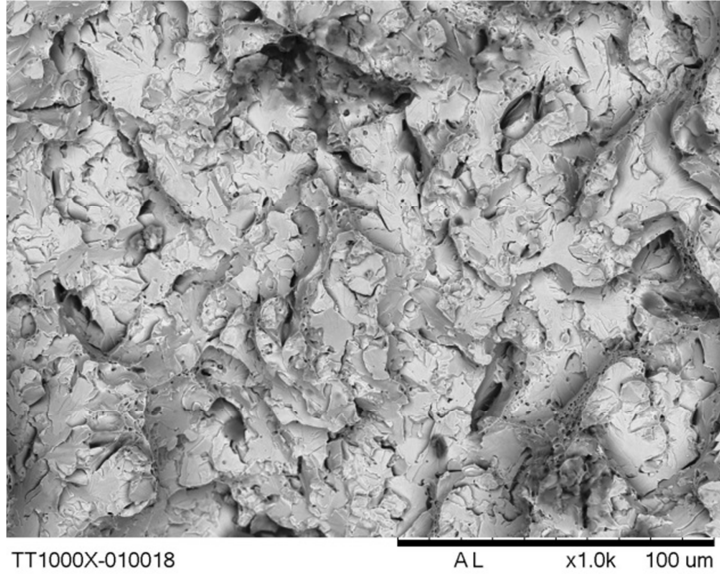

(b)

Figura 57 - Fractografia de corpos de prova Charpy do metal de solda. (a) condição CS (b) condição após TTAT, 1000 X, MEV.

Nota-se, pela análise da Figura 57, que com um aumento de 1000 vezes não é possível distinguir claramente a diferença entre os aspectos da fratura dos corpos de prova na condição "como soldado" (Figura 57a) e após TTAT (Figura 57b). Porém, com um aumento de 5000 vezes isto se torna viável conforme mostrado pela Figura 58.

$\mathrm{Na}$ condição CS observa-se a presença de microcavidades nucleadas em regiões com presença de microfases ou inclusões. Nota-se que tais microcavidades apresentam um perfil cônico e profundo o que indica a existência de deformação plástica nestes locais. O formato ovalado das microcavidade sugere um carregamento por cisalhamento, o que era de se esperar visto que tais corpos de prova foram aproveitados do ensaio de impacto Charpy. Entretanto, nota-se também a presença de faces com aparência plana que são características do mecanismo de clivagem. Sendo assim, tanto o mecanismo de fratura por "dimples" como clivagem estão presentes e a fratura pode ser considerada do tipo dúctil-frágil, vide Figura 58a. 


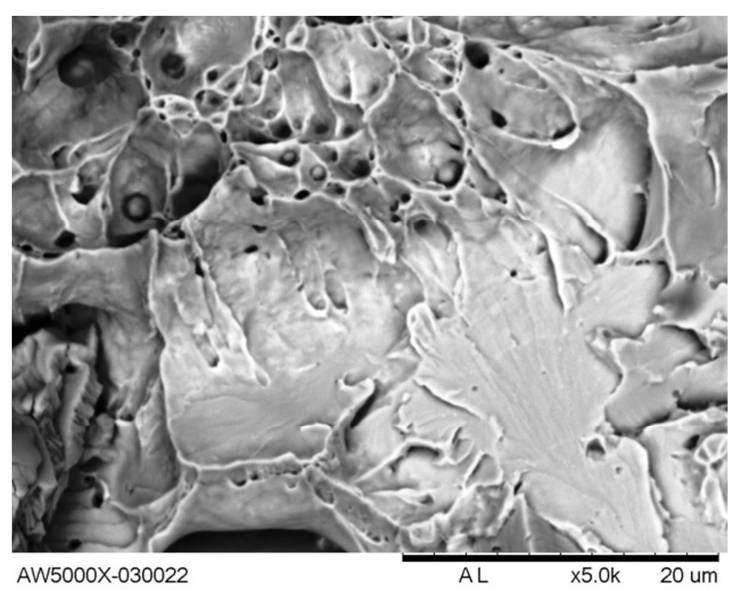

(a)

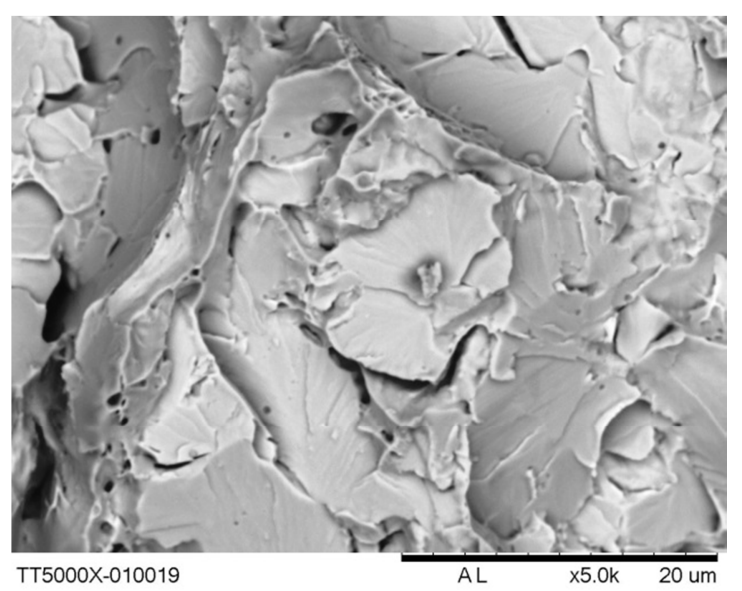

(b)

Figura 58 - Fractografia de corpos de prova Charpy do metal de solda. (a) condição CS (b) condição após TTAT, 5000 X, MEV.

Por outro lado, na condição TTAT, a fratura do corpo de prova ocorreu em planos cristalinos bem definidos e a aparência plana sugere uma fratura por clivagem onde as "marcas de rio" indicam a direção da fratura [62]. Deste modo, o mecanismo de fratura na condição TTAT é predominantemente por clivagem, o que indica uma fratura frágil, conforme apresentado na Figura 58b.

É importante salientar que tal conclusão baseia-se não apenas pela análise de um local isolado do corpo de prova mostrado na Figura 58, mas também pela análise por varredura de toda a superfície de fratura.

Durante a análise da superfície de fratura da condição CS foi observada uma região peculiar onde a ampliação evidenciou a presença de certa quantidade de partículas esféricas e outras amorfas conforme pode ser observado na Figura 59.

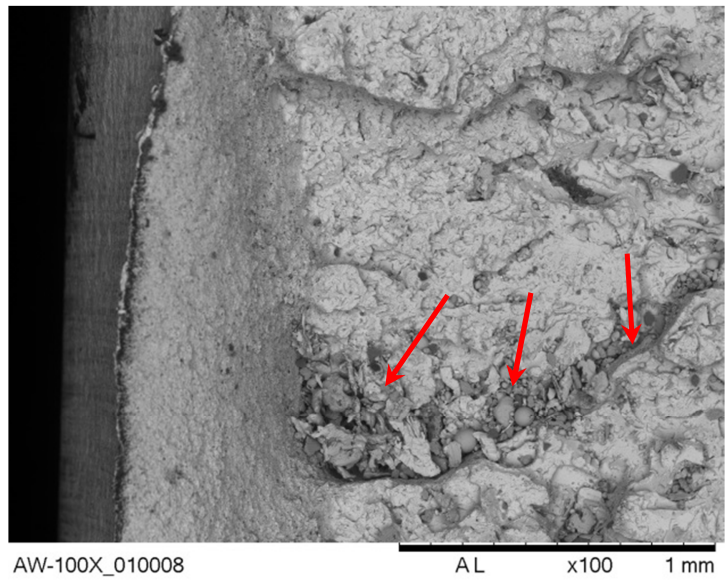

(a)

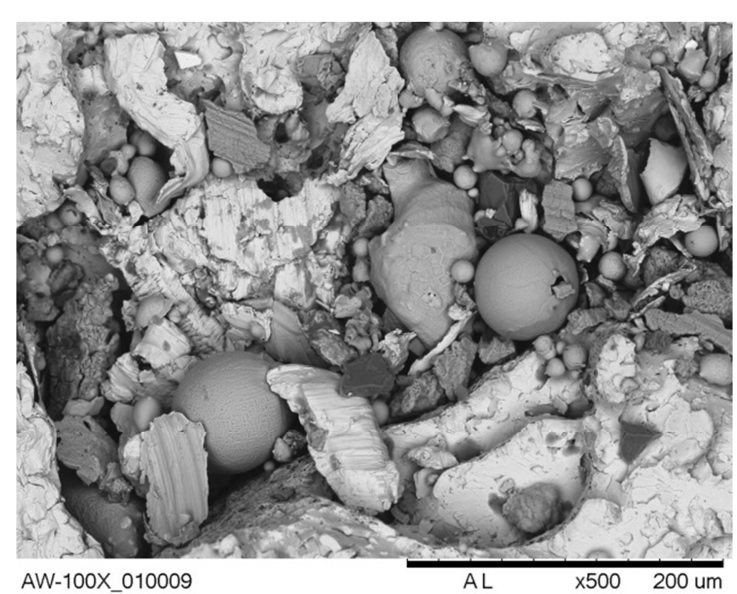

(b)

Figura 59 - Fractografia do corpo de prova Charpy (1.1) do metal de solda. As setas indicam o local de possível inclusão de escória (a) 100 X (b) 500, MEV. 
Uma analise detalhada desta região mostra a ocorrência de uma falta de fusão no local o que pode ter favorecido a inclusão de escória. De fato a morfologia das partículas encontradas vem de encontro com aquelas existentes no fluxo de soldagem do arame tubular. De qualquer modo, tudo indica que tal defeito produziu algum efeito deletério visto que o valor obtido no ensaio Charpy foi de 23J, inferior, portanto ao obtidos nos outros dois CP's, a saber: 31 e $36 \mathrm{~J}$.

\subsubsection{Microestrutura e correlação com a tenacidade}

Levando-se em consideração uma taxa de resfriamento de $20 \mathrm{~K} / \mathrm{s}$ os diagramas TTT e CCT do ASTM A36 indicam a formação de uma microestrutura composta basicamente por ferrita, perlita e possivelmente bainita nas regiões próximas à LF conforme ilustrado na Figura 60.

Na Figura 61 é mostrada a microestrutura observada o que corrobora com o previsto pelos diagramas.

Nota-se que na condição "como soldado", a microestrutura próxima à linha de fusão é bastante heterogênea, sendo constituída de diversas morfologias de ferrita, perlita e possivelmente bainita ou até mesmo martensita.

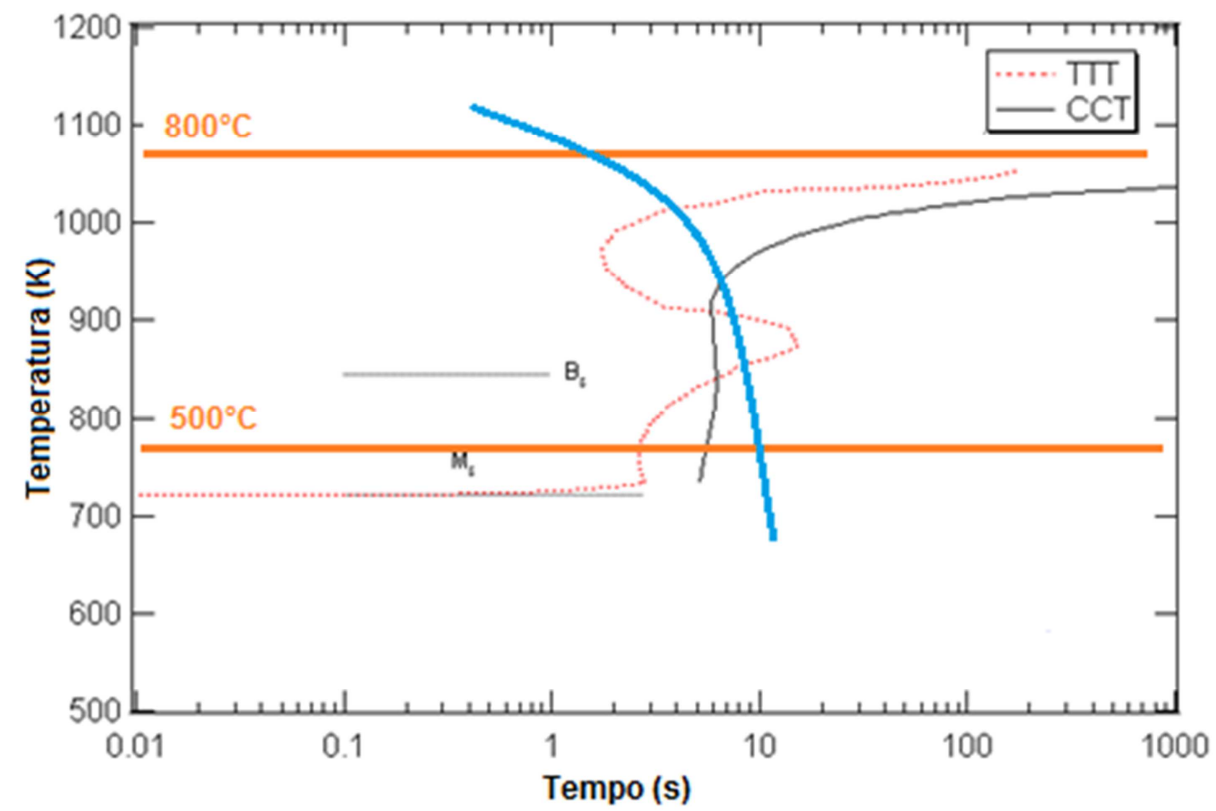

Figura 60 - Diagramas TTT e CCT para a composição química do aço ASTM A36 utilizado neste trabalho. Adaptado de [61] 


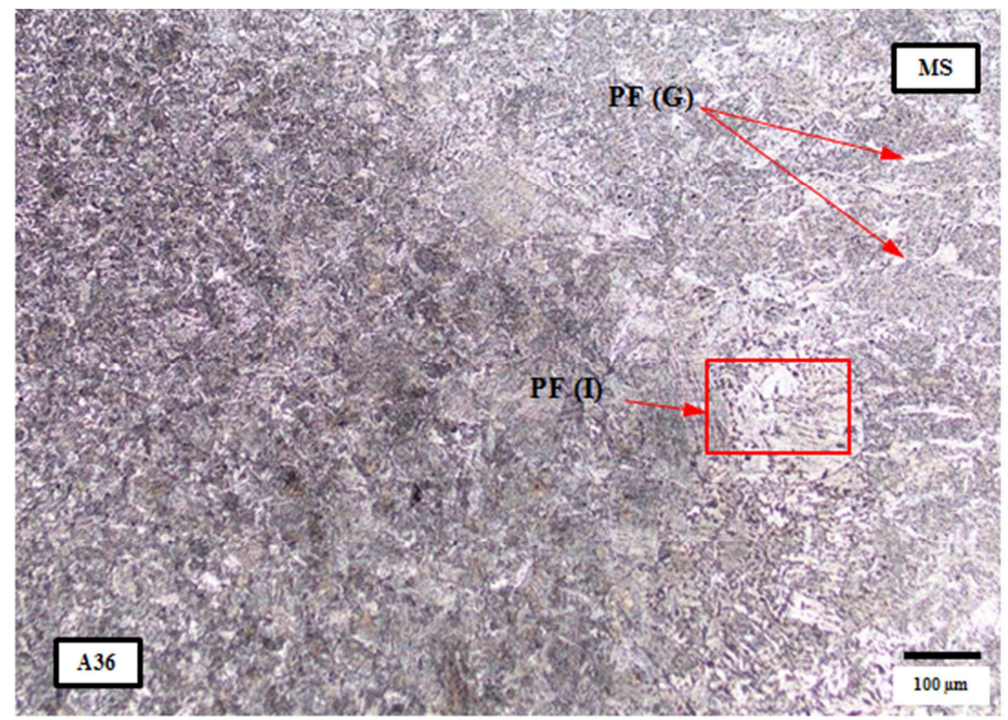

Figura 61 - Microestrutura - região A - linha de fusão A36 x MS condição CS, $\mathrm{MO}$ - ataque: Nital $2 \%$

$\mathrm{PF}(\mathrm{G})$ - ferrita primária de contorno de grão; $\mathrm{PF}(\mathrm{I})$ - ferrita idiomórfica

Na Figura 62 é mostrada a microestrutura do aço ASTM A36 a $5 \mathrm{~mm}$ da linha de fusão que apresentou um valor de $35 \mathrm{~J}$ de energia absorvida na condição "como soldado" possivelmente por encontrar-se na região intercrítica. Entretanto, a $1 \mathrm{~mm} \mathrm{da}$ linha de fusão, a microestrutura de natureza acicular pode ter contribuído ao acréscimo da tenacidade, onde foi observado um valor médio de 95J.

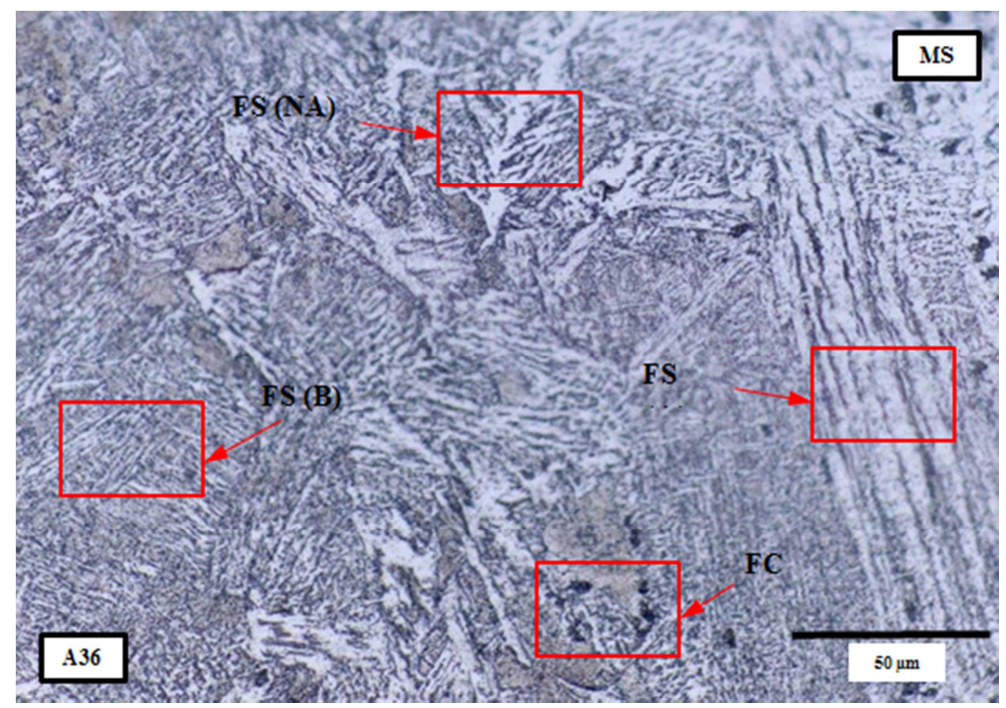

Figura 62 - Microestrutura - região A - linha de fusão A36 x MS condição CS, $\mathrm{MO}$ - ataque: Nital $2 \%$

FS - placas laterais de ferrita de Widmanstätten; FS(NA) - ferrita de Widmanstätten com microfase não alinhada; $F S(B)$ - bainita; $F C$ - agregado ferrita-carbonetos

Na Figura 63 é mostrado o aspecto da microestrutura após o TTAT. 


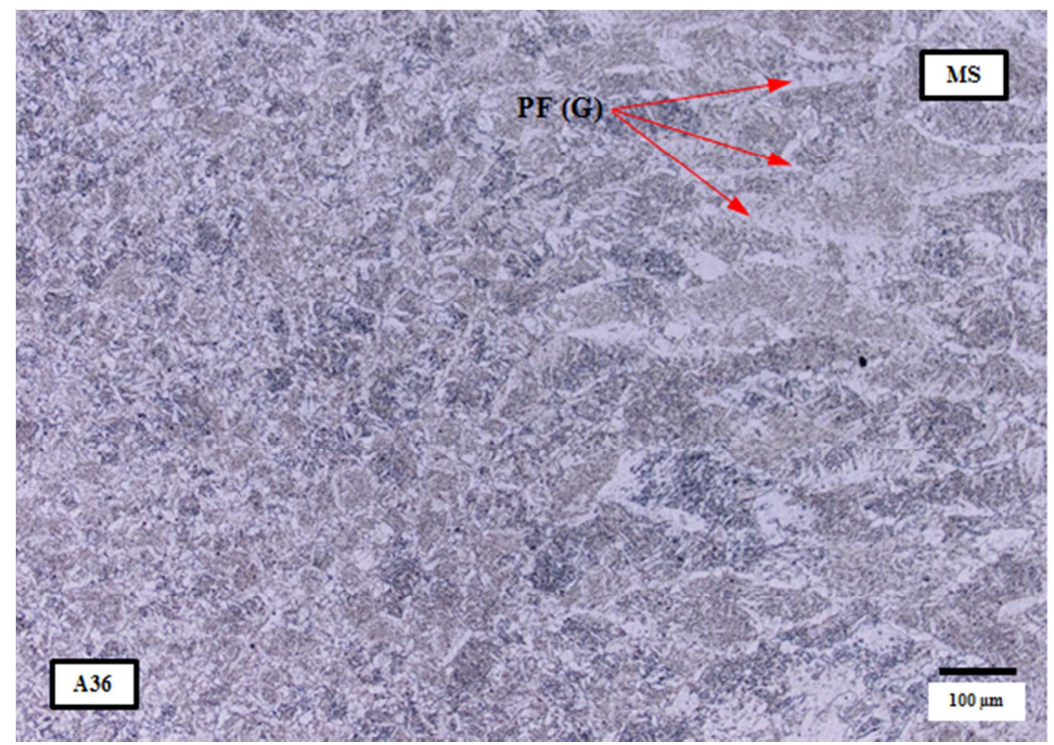

Figura 63 - Microestrutura - região A - linha de fusão A36 x MS condição TTAT, MO - ataque: Nital $2 \%$

$\operatorname{PF}(G)$ - ferrita primária de contorno de grão

Nota-se que após o tratamento térmico houve uma homogeneização da microestrutura e o efeito do TTAT não foi tão significativo a $1 \mathrm{~mm}$ da LF porém a $5 \mathrm{~mm}$ o seu efeito foi mais pronunciado, promovendo o aumento do valor médio de tenacidade de 35 para 95J nesta região. Provavelmente, por se tratar de uma região intercrítica, na condição "como soldado" a mesma apresentava microconstituintes duros como bainita ou martensita sobre uma matriz ferrítica onde, após o TTAT tais microconstituintes se transformaram. A Figura 64 mostra a mesma região analisada, porém com um aumento maior.

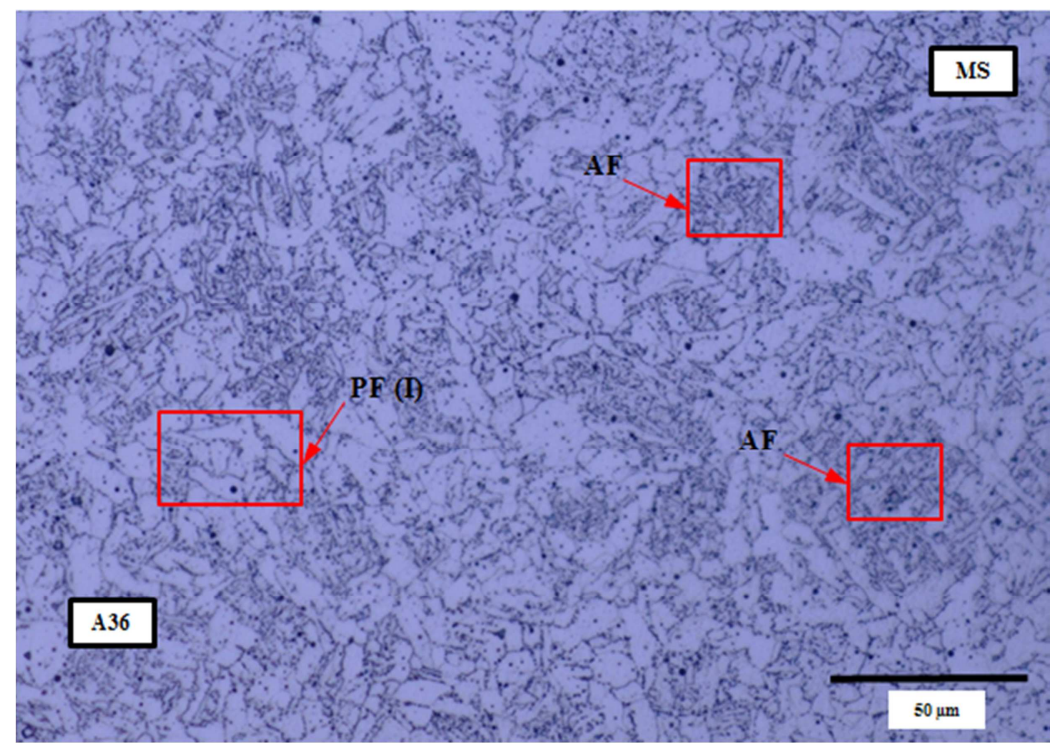

Figura 64 - Microestrutura - região A - linha de fusão A36 x MS condição TTAT, MO - ataque: Nital $2 \%$ $\mathrm{PF}(\mathrm{I})$ - ferrita idiomórfica; $\mathrm{AF}$ - ferrita acicular 
Na Figura 65 é apresentado o diagrama TTT e CCT do aço ASTM A514.

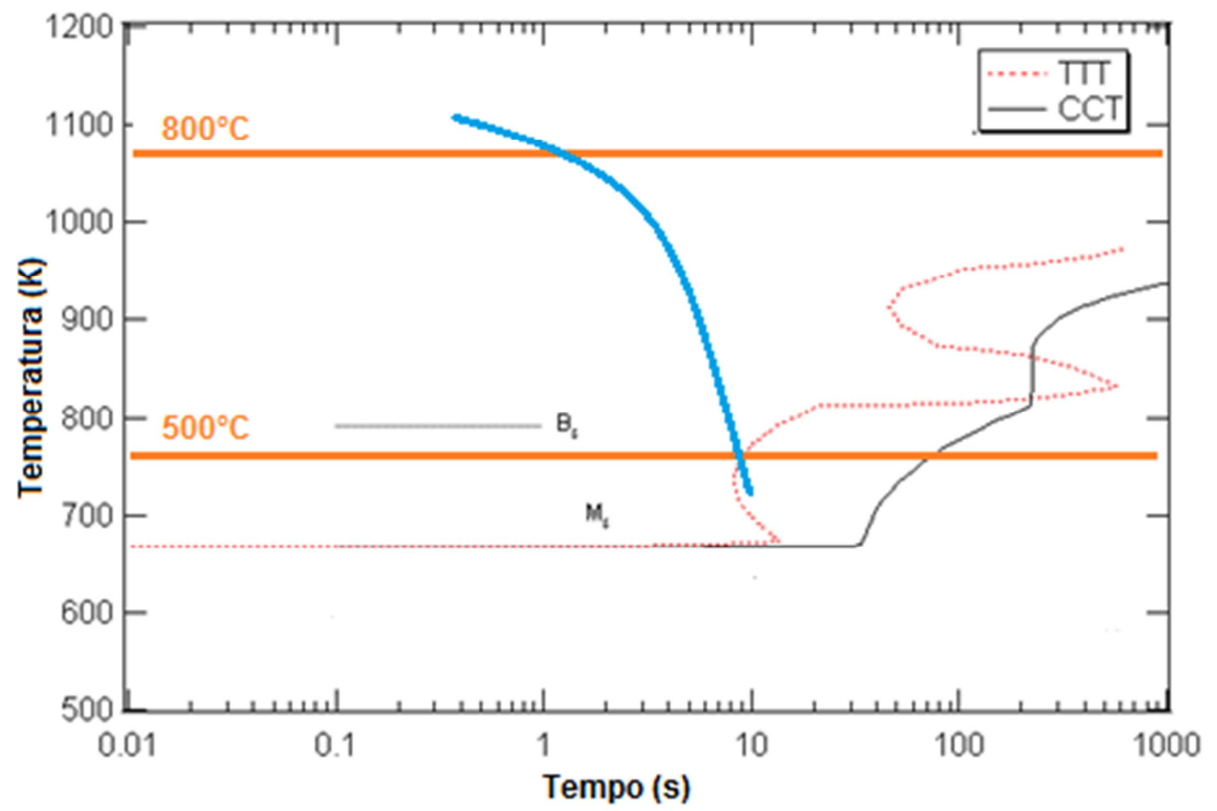

Figura 65 - Diagramas TTT e CCT para a composição química do aço ASTM A514 Gr.Q utilizado neste trabalho. Adaptado de [61]

Levando-se em consideração uma taxa de resfriamento de $20 \mathrm{~K} / \mathrm{s}$ era de se esperar a obtenção de uma microestrutura basicamente composta por martensita.

$\mathrm{Na}$ Figura 66 é mostrada a microestrutura observada o que corrobora com o previsto pelos diagramas.

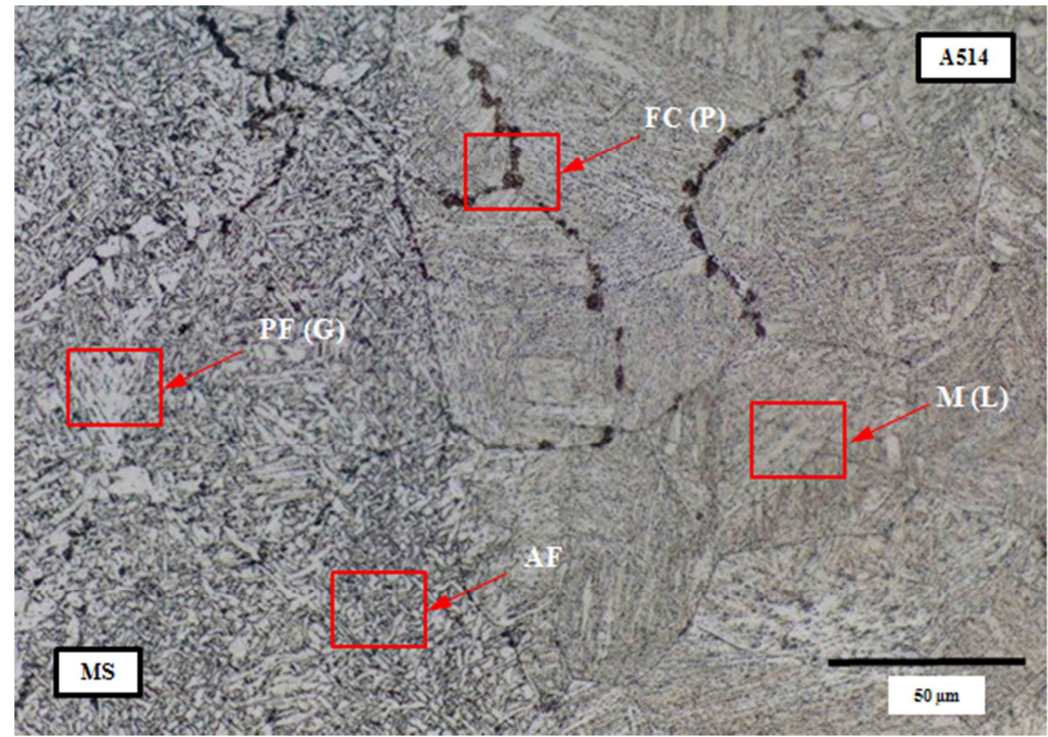

Figura 66 - Microestrutura - região B - linha de fusão A514 x MS condição CS, MO - ataque: Nital $2 \%$

$\mathrm{PF}(\mathrm{G})$ - ferrita primária de contorno de grão; $\mathrm{AF}$ - ferrita acicular; $\mathrm{FC}(\mathrm{P})$ - agregado ferrita-carbonetos; $\mathrm{M}(\mathrm{L})$ - martensita 
Observa-se a presença de martensita, porém o que chama a atenção é a presença significativa de perlita no contorno do grão austenítico no ASTM A514 o que pode ter contribuído na redução da tenacidade encontrada a $1 \mathrm{~mm}$ da linha de fusão. Porém, a $5 \mathrm{~mm}$ da LF a tenacidade atinge o valor de 183J na condição "como soldado" o que vem de encontro com diversos estudos onde foi verificado que determinadas morfologias de microestrutura martensitica (ripas) produzem a melhor combinação de resistência mecânica e tenacidade do que qualquer outra microestrutura produzida em um aço, mesmo se comparada às microestruturas bainíticas [14,15].

$\mathrm{Na}$ Figura 67 pode ser observado o aspecto da microestrutura da linha de fusão MS x ASTM A514 após o TTAT.

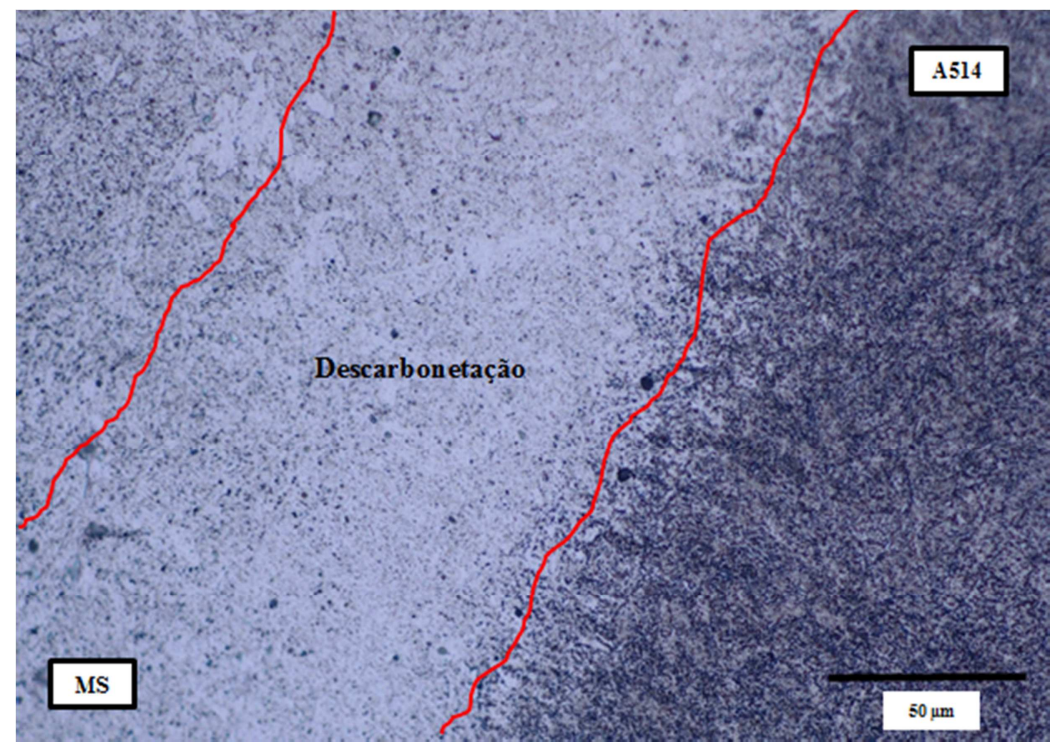

Figura 67 - Microestrutura - região B - linha de fusão A514 x MS condição TTAT, MO - ataque: Nital $2 \%$

O aspecto da microestrutura após o TTAT e a significativa queda de dureza na região da linha de fusão sugere que houve uma descarbonetação. Este fenômeno é favorecido pela relação tempo $x$ temperatura do tratamento térmico, sendo causado pela difusão de carbono na linha de fusão que é mais pronunciado em soldas, cujo metal de adição possui um conteúdo de carbono inferior ao metal de base, que é o caso do metal de solda C-Mn com o A514 [14]. Entretanto, a $1 \mathrm{~mm}$ da LF ocorreu apenas uma ligeira queda na tenacidade. Notou-se um leve aumento da tenacidade a $5 \mathrm{~mm}$ da LF decorrente do revenimento da martensita.

Não foram observadas trincas, inclusive intergranulares (típicas da fragilização no revenido) que poderiam ser esperadas, após a execução do TTAT no A514. O fato de $\mathrm{o}$ tratamento térmico ter sido realizado a uma temperatura de $600{ }^{\circ} \mathrm{C}$, portanto fora 
da faixa crítica de $450^{\circ}$ a $550^{\circ} \mathrm{C}$, além de uma taxa de aquecimento e resfriamento adequados podem ter influenciado de modo a evitar tal fragilização. É bastante provável que o baixo teor de fósforo, a quase ausência de elementos tais como antimônio, estanho e arsênio e também a presença de vanádio tornaram o A514 menos susceptível a este fenômeno [63].

Na Figura 68 é mostrada a microestrutura do metal de solda na condição como soldado.

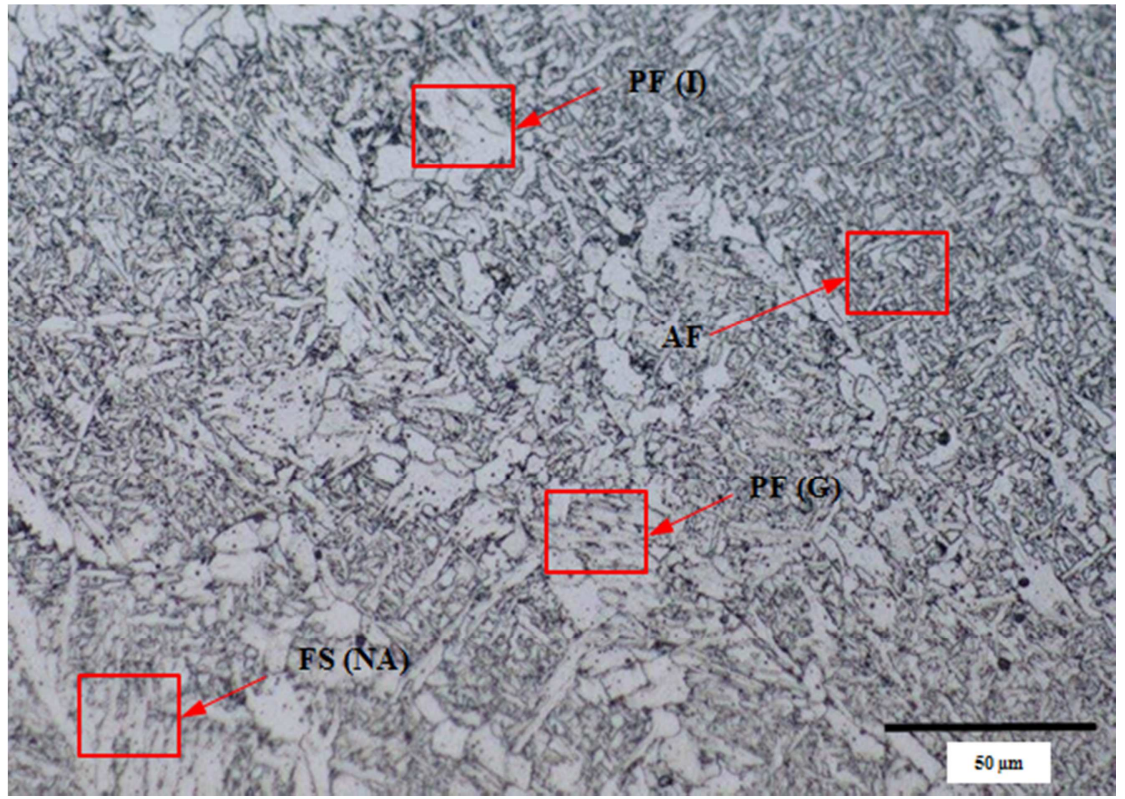

Figura 68 - Microestrutura - região C (raiz) - metal de solda, condição CS, $\mathrm{MO}$ - ataque: Nital $2 \%$

$P F(G)$ - ferrita primária de contorno de grão; $P F(I)$ - ferrita idiomórfica; $F S(N A)$ - ferrita de Widmanstätten com microfase não alinhada; $\mathrm{AF}$ - ferrita acicular

Considerando-se a composição química do metal de solda depositado conforme a Tabela 5 e os parâmetros de soldagem empregados, uma microestrutura composta basicamente por ferrita é a esperada. Na Figura 68 é mostrada uma microestrutura composta basicamente por FS(A)/FS(NA) e também por ferrita acicular.

No que tange ao metal de solda nota-se que para ambas as condições, "como soldado" e após o TTAT os valores de tenacidade foram baixos, médias de $30 \mathrm{~J}$ e $12 \mathrm{~J}$ respectivamente.

Aqui cabe destacar quais são os fatores que controlam as propriedades do metal de solda, mais especificamente a tenacidade, que segundo Evans e Bailey [21] são: 
(i) Taxa de resfriamento;

(ii) Número de passes e como cada passe modifica a microestrutura do anterior;

(iii) Composição química do metal de solda.

O tempo de resfriamento (t8/5) é controlada pelo aporte de calor, temperatura de pré-aquecimento e interpasses. Taxas de resfriamento mais baixas produzem microestruturas mais grosseiras o que tendem a reduzir a tenacidade [21]. É importante salientar que os corpos de prova de impacto Charpy para avaliação do metal de solda foram removidos na raiz da junta. Observar que na raiz o aporte de calor é maior, e que na posição $3 G$ é necessário oscilar o eletrodo. Assim, deposita-se uma menor quantidade de passes e consequentemente a porcentagem de região colunar é maior, reduzindo a tenacidade nesta região. De fato, analisando-se o Anexo $\mathrm{C}$ vê-se que os maiores aportes de calor obtidos foram justamente na raiz.

O número e a sequência de passes são importantes nas soldas de aços ferríticos, pois cada passe aquece uma porção do metal de solda pré-existente acima da temperatura de transformação formando austenita. Aquecendo a altas temperaturas, os grãos de austenita crescem e no resfriamento há a formação de microestruturas grosseiras, enquanto o aquecimento a temperaturas mais baixas resultam em microestruturas mais finas o que apresenta melhor tenacidade. Assim, é de se esperar que uma peça soldada na posição vertical apresente microestruturas mais grosseiras, visto que na maioria das situações é necessário oscilar o eletrodo, o que aumenta o aporte de calor. O número de passes também é menor e assim menor é a fração de metal de solda refinado pelos passes subsequentes ${ }^{28}[14,15,21]$. Na Figura 69 é mostrada a localização do entalhe do corpo de prova de impacto Charpy na raiz da solda. A proporção de grãos colunares foi estimada em $40 \%$, a de grãos grosseiros é de $30 \%$ e de grãos refinados de $30 \%$.

Deste modo explica-se o porquê de algumas normas de qualificação de procedimentos de soldagem, como por exemplo, o código ASME IX [64], estabelecerem que a soldagem da peça de testes na posição $3 G$ qualificar a soldagem em todas as posições quando se tem requisitos de impacto.

A respeito da composição química na raiz é importante destacar o efeito da diluição. Sendo assim, foi realizada nesta região uma análise química por espectrometria na superfície da fratura do corpo de prova Charpy. Na Figura 69 é mostrada a superfície ensaiada e na Tabela 24 os valores obtidos.

\footnotetext{
${ }^{28}$ A título de ilustração, enquanto a soldagem da peça de testes de $76 \mathrm{~mm}$ teve 76 passes, a mesma peça soldada na posição horizontal teve 115 passes.
} 

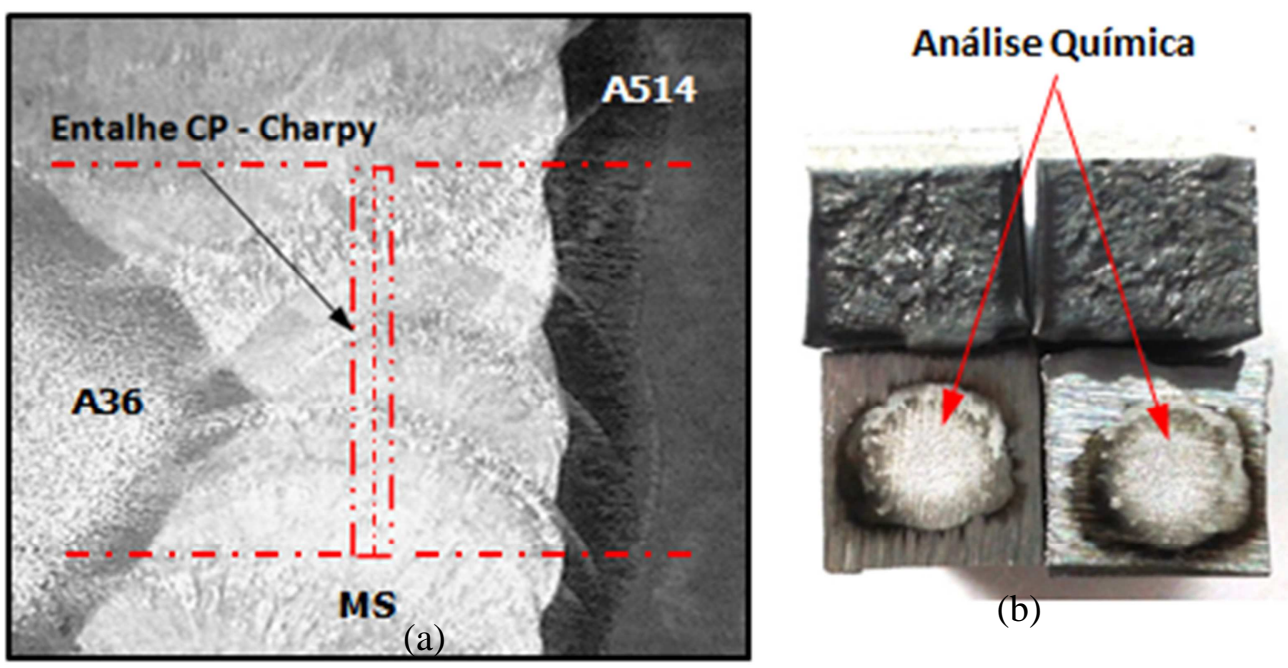

Figura 69 - (a) Macrografia da região $C$ (raiz) indicando a posição do entalhe dos corpos de prova Charpy, ataque Nital $5 \%$. (b) Análise química do metal de solda realizada na superfície fraturada do corpo de prova Charpy.

Tabela 24 - Análise química do metal de solda na raiz. Valores em \%

\begin{tabular}{c|c|c|c|c|c|c|c|c|c}
\hline $\begin{array}{c}\text { elemento } \\
\text { local }\end{array}$ & $\mathrm{C}$ & $\mathrm{Mn}$ & $\mathrm{P}$ & $\mathrm{S}$ & $\mathrm{Si}$ & $\mathrm{Ni}$ & $\mathrm{Cr}$ & $\mathrm{Mo}$ & $\mathrm{V}$ \\
\hline $\begin{array}{c}\text { Metal de } \\
\text { Adição }\end{array}$ & 0,05 & 1,21 & 0,015 & 0,011 & 0,53 & 0,02 & 0,01 & 0,02 & 0,02 \\
\hline $\begin{array}{c}\text { Metal de } \\
\text { Solda Raiz }\end{array}$ & 0,09 & 1,44 & 0,016 & 0,010 & 0,64 & 0,17 & 0,15 & 0,05 & 0,02 \\
\hline
\end{tabular}

Nota-se, pela análise dos valores que a diluição na raiz atuou basicamente no sentido de aumentar o teor de carbono e elementos de liga no metal de solda. Considerando-se tal composição existe a possibilidade de formação de microfases como a M-A. De fato, no perfil de dureza do metal de solda, foi anotado um pico de dureza na condição CS, sendo o valor discrepante dos demais o que sugeriu a presença de algum microconstituinte duro naquela região. Como já discutido anteriormente na revisão bibliográfica deste trabalho [25,26,27], o constituinte M-A pode reduzir a tenacidade do metal de solda, quando este se apresenta na forma de blocos constituídos por martensita associados com carbonetos em ilhas dispersas aleatoriamente.

Apesar da micrografia realizada no metal de solda não revelar a presença de microfases, mas apenas morfologias de ferrita, é importante notar que o ataque foi realizado com o Nital, cuja característica básica é revelar contornos de grãos ferríticos $[7,65]$. Deste modo para se revelar a presença de outros microconstituintes ou microfases deve-se preparar um ataque mais adequado para este propósito. 
$\mathrm{O}$ ataque LePera mostra-se adequado para este fim, visto que as fases ferrita, bainita, martensita e austenita podem ser revelados com bastante nitidez, principalmente as duas últimas. Se o aço é atacado com o reagente Lepera, a ferrita é revelada na cor azul ou azul escuro, a bainita apresenta uma coloração que tende ao marrom e tanto a martensita quando a austenita são evidenciadas na cor branca [66]

Assim, a superfície da fratura indicada na Figura 69 foi preparada para análise por microscopia óptica é atacada com o reagente Lepera. Na Figura 70 é mostrada uma imagem da microestrutura.

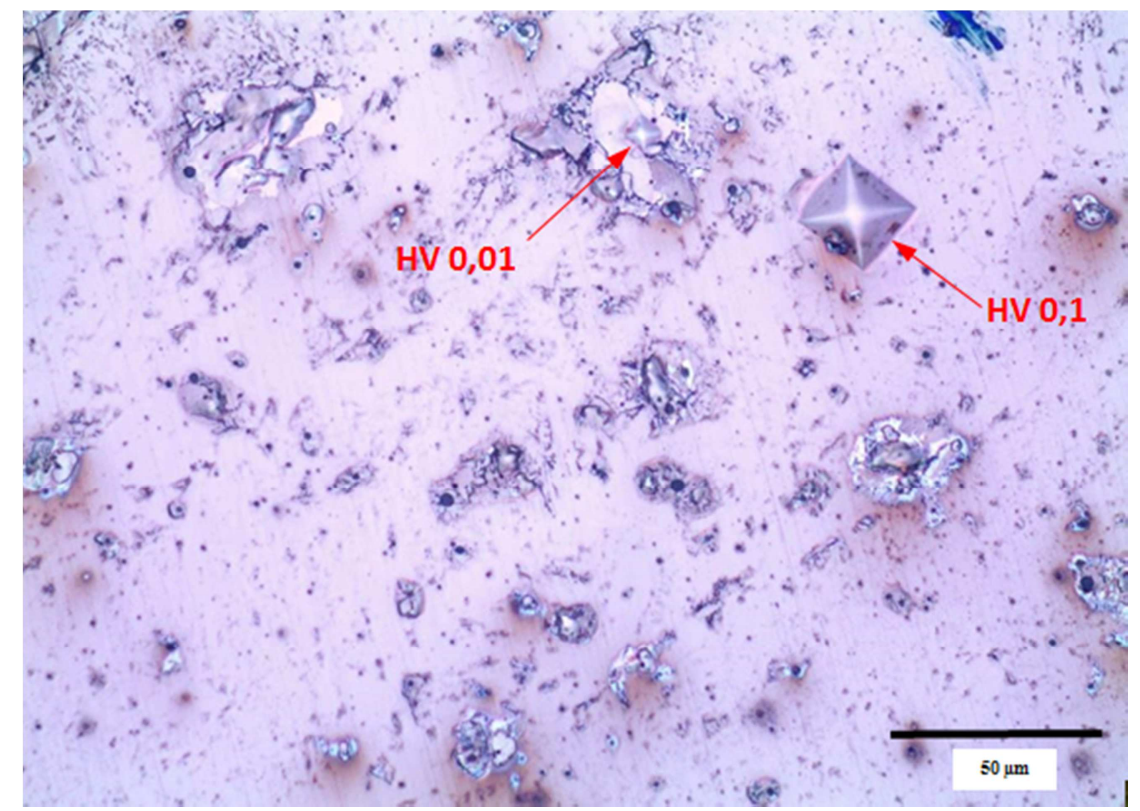

Figura 70 - Microestrutura - região C (raiz) - metal de solda, condição CS, aumento 500 X, MO - ataque: LePera Modificado.

A microestrutura revelou claramente a presença de microconstituintes brancos que são indicativos da martensita e austenita. Para efeitos de comprovação, foram realizadas medições de dureza, sendo uma na matriz empregando a escala HV 0,1 (100g) e outra no microconstituinte branco na escala HV 0,01 (10g). A média de três medições para a matriz foi de $208 \pm 3 \mathrm{HV}-0,1$ e a média para o microconstituinte branco foi de $341 \pm 6 \mathrm{HV}-0,01$. É importante salientar que a dureza da martensita depende basicamente do teor de carbono. Na Figura 71 é mostrado um gráfico que relaciona o teor de carbono e a dureza da martensita. Para um teor aproximado de $0,1 \%$ o valor corresponde de dureza é de aproximadamente $350 \mathrm{DPH}$ o que corrobora com a hipotése, de qual tal microconstituinte trata-se de martensita ou de M-A. 


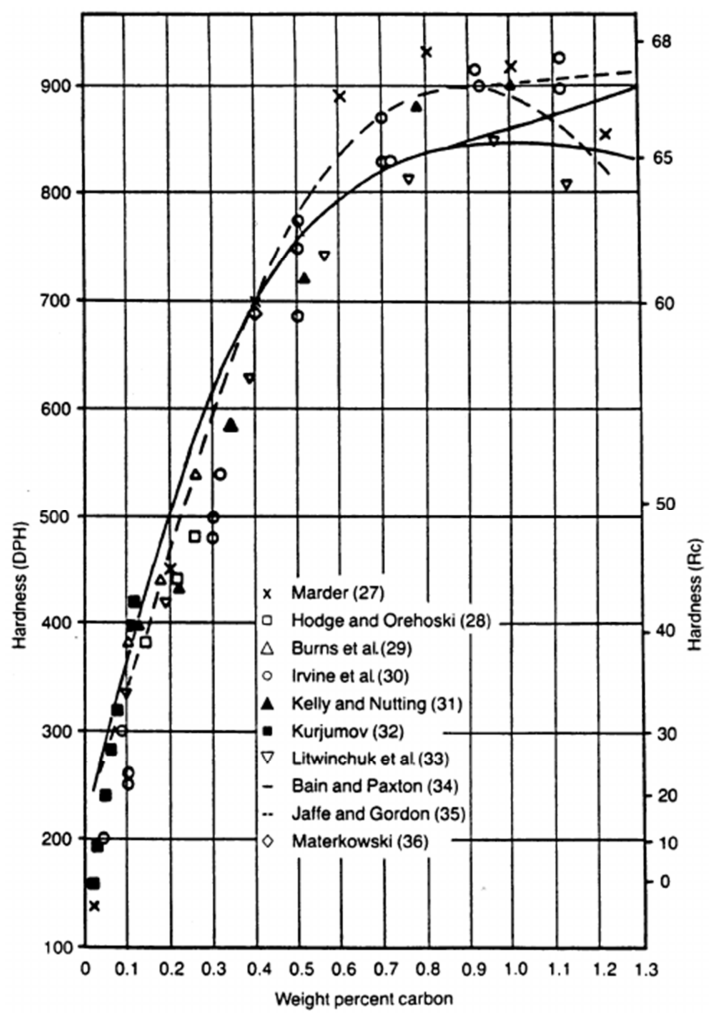

Figura 71 - Dureza de microestruturas martensíticas em função do teor de carbono no aço [67].

Em caráter complementar, a mesma microestrutura foi observada no MEV, e as imagens obtidas estão mostradas na Figura 72.
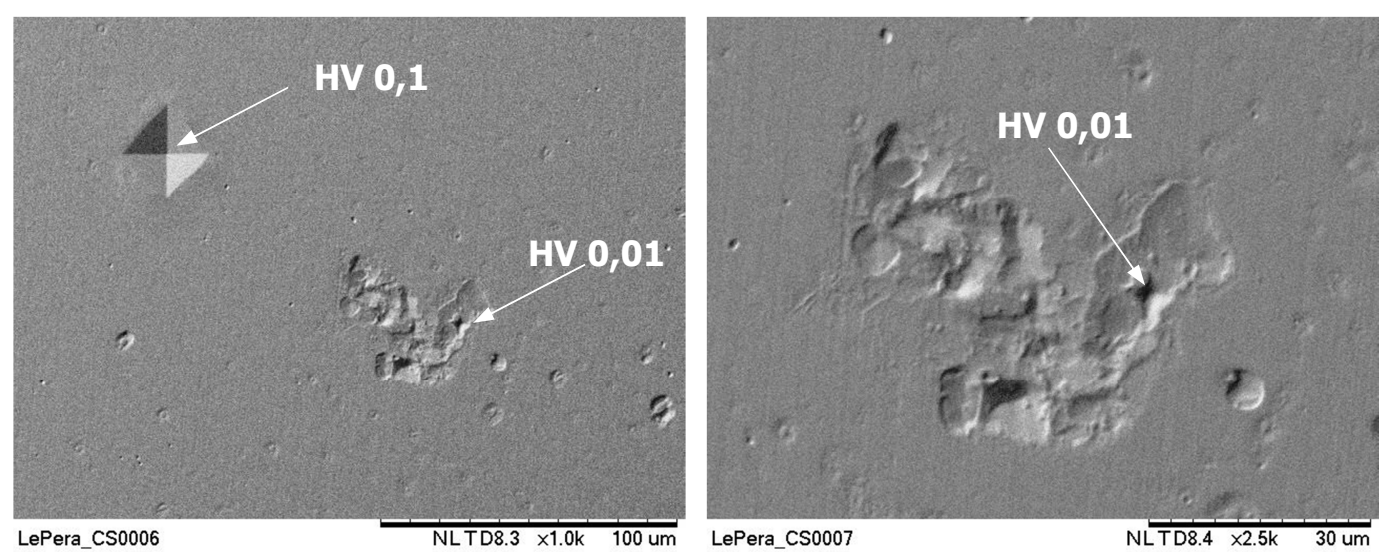

Figura 72 - Microfases M-A-B - região C (raiz) - metal de solda, condição CS, aumento 1000 X (a) e 2500 X (b), MEV - ataque: LePera Modificado.

Na Figura 73 observa-se o aspecto da microestrutura do metal de solda após o tratamento térmico de alívio de tensões. 


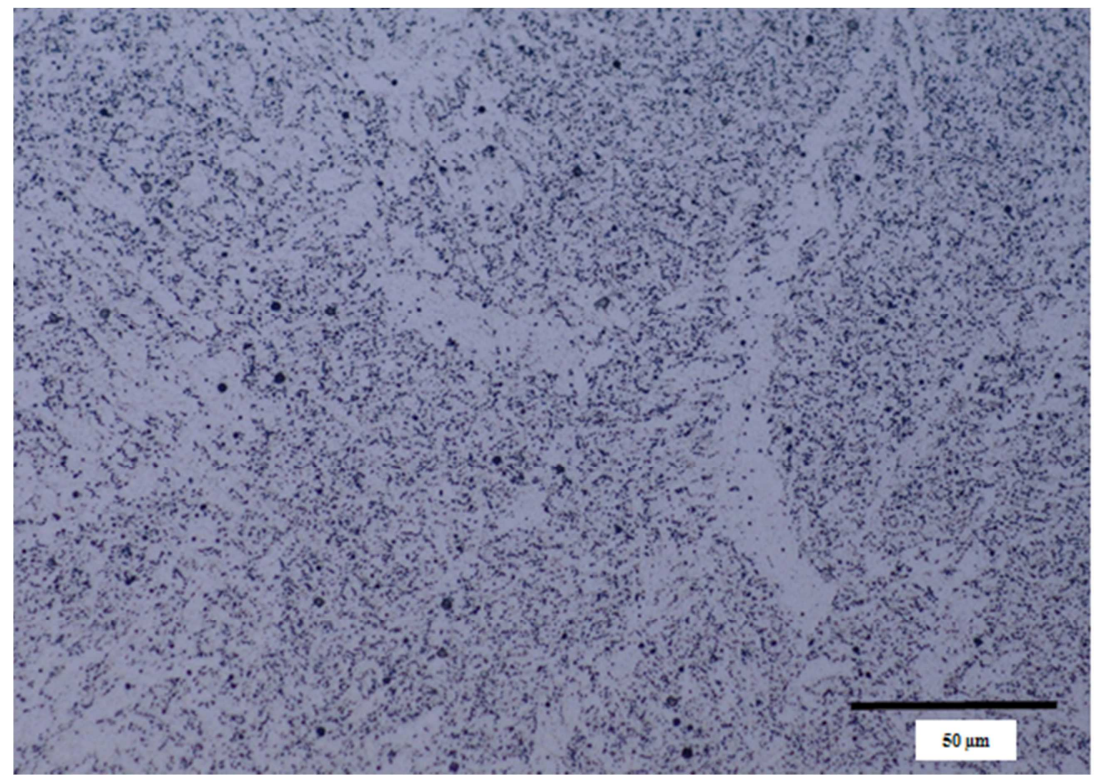

Figura 73 - Microestrutura - região C (raiz) - metal de solda, condição TTAT, aumento $500 \mathrm{X}, \mathrm{MO}$ - ataque: Nital $2 \%$

Observa-se que após o TTAT a microestrutura apresentou basicamente ferrita de contorno de grão, ferrita de placas laterais e a presença de carbonetos precipitados. Tal morfologia de ferrita é deletéria para a tenacidade do metal de solda visto que estas se constituem caminhos preferenciais para a fácil propagação de trincas [15,17]. Nota-se também a presença de grande quantidade de possíveis carbonetos dispersos na matriz. Mais uma vez é importante salientar que o ataque de Nital não é o mais adequado para revelar a presença de carbonetos, sendo o Picral o reagente mais adequado para este fim [7,65]. Na Figura 74 está indicado o resultado obtido com o ataque usando o Picral.

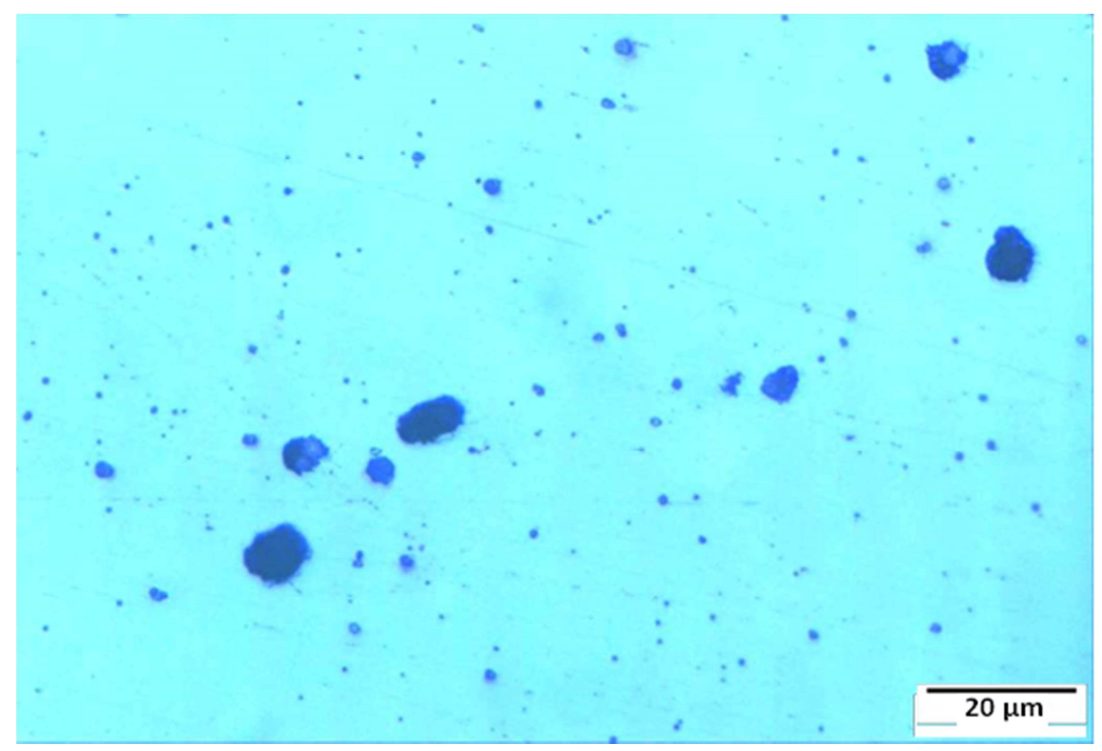

Figura 74 - Carbonetos - região C (raiz) - metal de solda, condição TTAT, aumento $1000 \mathrm{X}, \mathrm{MO}$ - ataque: Picral 
Na Figura 74 é mostrada a presença de possíveis carbonetos precipitados. À medida que os carbonetos estejam finamente dispersos na matriz do metal de solda, o fenômeno da coalescência já ocorre mesmo em curtos ciclos térmicos da soldagem, sendo mais intensificado quando a junta sofre um TTAT [14]. Esta poderia ser uma explicação para a queda da tenacidade do metal de solda após o TTAT, pois o coalescimento dos carbonetos provoca um aumento na temperatura da transição, ou em outras palavras, em um decréscimo da tenacidade [15].

Para comprovar a existência de carbonetos foi realizada uma microanálise química por energia dispersiva (EDS). Para tal fim, inicialmente foram identificados no MEV possíveis carbonetos coalescidos, como pode ser notado na Figura 75. O contraste mostrado à direita evidencia a presença de partículas, não de poros. $\mathrm{Na}$ Figura 76 está delimitada a área de interesse a ser analisada.
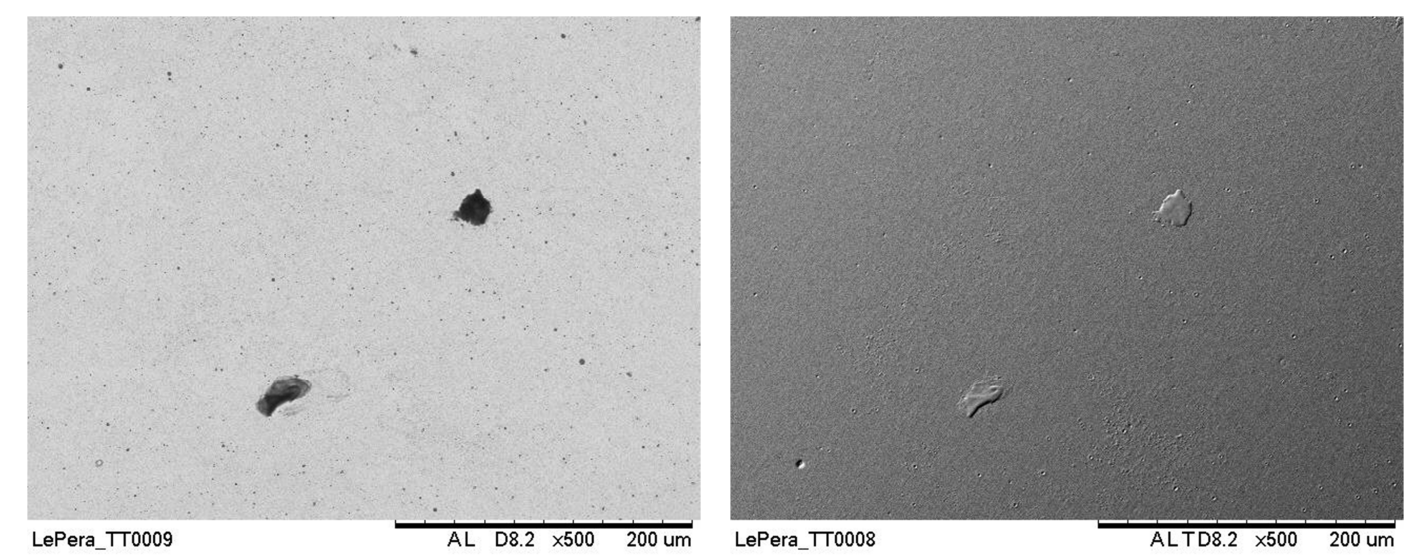

Figura 75 - Carbonetos - região C (raiz) - metal de solda, condição TTAT, aumento $500 \mathrm{X}, \mathrm{MEV}$ - ataque: LePera Modificado.

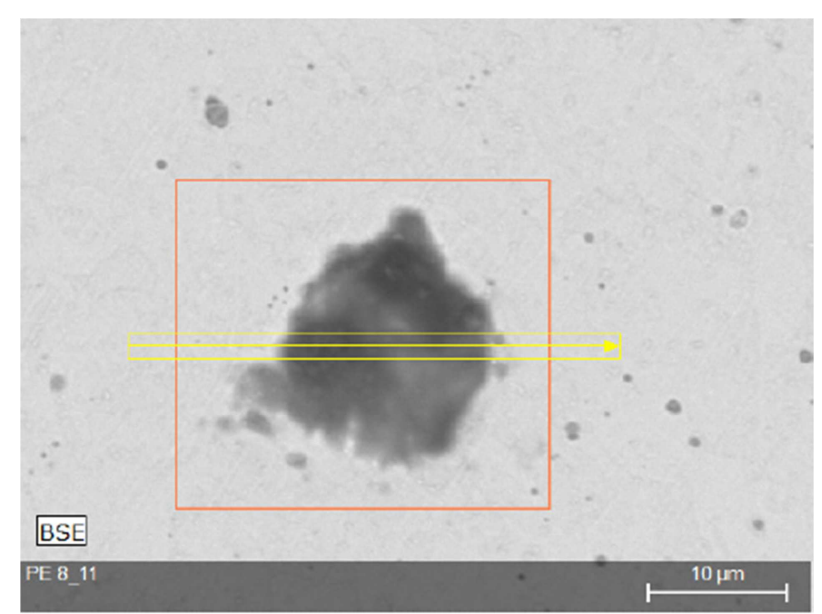

Figura 76 - Perfil de composição de região contendo carboneto - região $C$ (raiz) - metal de solda, condição TTAT, MEV - ataque: LePera Modificado. 
Na Figura 77 é mostrado o espectro obtido por EDS onde se destaca a presença dos elementos Fe e $\mathrm{C}$, sendo o Fe claramente identificado pelos picos bem definidos $\mathrm{Ka}$ e $\mathrm{K} \beta$ na posição de faixa de energia de 6 a $7,5 \mathrm{keV}$ sendo a razão dos picos de aproximadamente 10:1. O elemento C também pode ser claramente identificado através de um pico anotado para energias entre 0,2 e 0,4 keV.

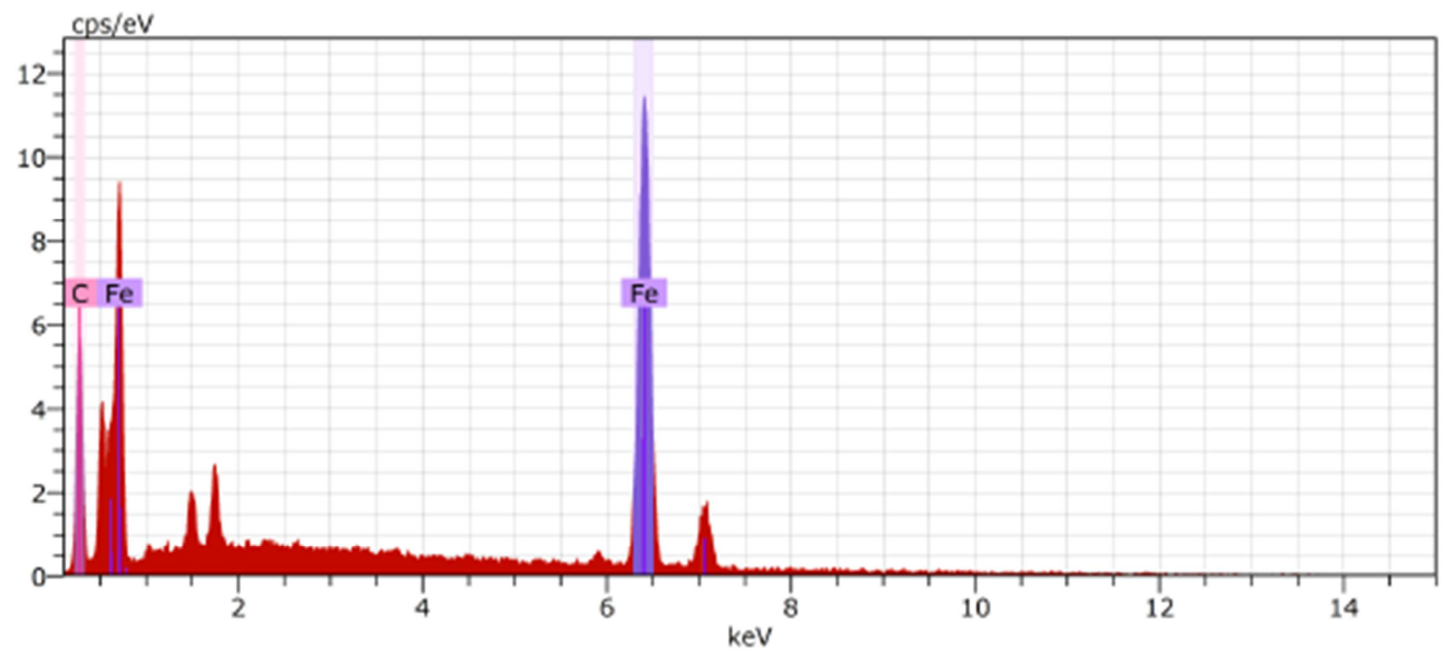

Figura 7

7 - Perfil de composição de região contendo carboneto - região C (raiz) - metal de solda, condição TTAT, MEV - ataque: LePera Modificado.

A Figura 78 mostra um perfil de composição na região contendo o carboneto analisado. Nota-se que o perfil para a matriz corresponde a composição química de um aço carbono, enquanto que, o perfil obtido no interior da partícula sugere a presença de um carboneto de ferro de estequiometria diferente da cementita.

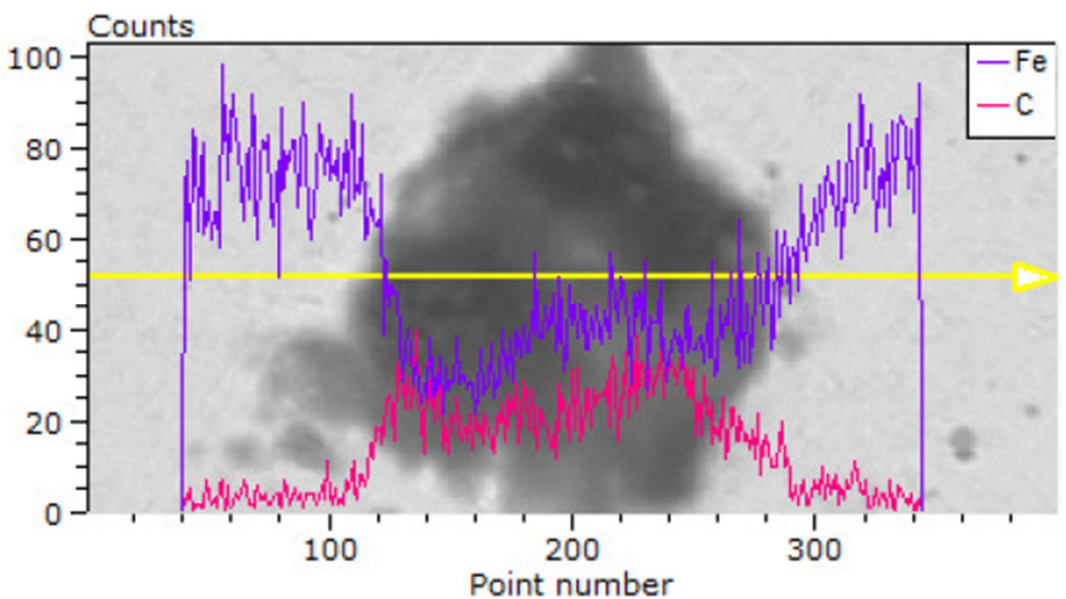

Figura 78 - Perfil de composição de região contendo carboneto - região C (raiz) - metal de solda, condição TTAT, MEV - ataque: LePera Modificado. 
Diante do exposto, as possíveis causas da baixa tenacidade encontrada no metal de solda, tanto na condição CS, como na condição TTAT podem ser resumidas a seguir:

- Frações de grãos colunares e grosseiros na raiz da solda;

- Presença de ferrita de contorno de grão e de placas laterais em detrimento da ferrita acicular.

- Efeitos da diluição na região da raiz e consequente formação de microfases frágeis (M-A);

- Precipitação e coalescimento de carbonetos após tratamento térmico de alívio de tensões. 


\section{COMENTÁRIOS FINAIS}

De todos os aspectos abordados neste trabalho, é a tenacidade no metal de solda o ponto crítico para a soldagem de juntas de ASTM A36 com o ASTM A514 pelo processo arame tubular.

Os valores de tenacidade obtidos no metal de solda retratam dois cenários distintos: o primeiro é que, apesar do baixo valor médio de $30 \mathrm{~J}$ na condição CS, o mesmo ainda atende os requisitos de impacto da norma AWS D1.1. O segundo é que o valor médio de 12J na condição TTAT não atendem tais requisitos.

$\mathrm{Na}$ condição CS o fato do valor de 30J estar próximo do mínimo exigido também requer atenção, sendo interessante a obtenção de valores com maiores margens de segurança. Na condição TTAT é necessário a busca por uma alternativa que viabilize a soldagem em situações onde o emprego do tratamento térmico é fundamental.

Dentre as alternativas possíveis, a que tem maior potencial de promover resultados práticos é a escolha adequada do consumível mais adequado para cada situação.

Para a condição CS ainda seria possível o emprego do E71T-1 de forma mais satisfatória desde que sejam obedecidos alguns limites mais estreitos de composição química do que aqueles estabelecidos pela norma. Este trabalho mostrou que o teor de carbono do metal de solda na raiz aumentou de $0,05 \%$ para $0,09 \%$ devido ao efeito da diluição, promovendo os efeitos deletérios já discutidos. Deste modo, a alternativa mais econômica seria escolher uma corrida onde o teor de $C$ do consumível seja 0 menor possível. Há fabricantes que produzem arames E71T-1 com teor médio de $\mathrm{C}$ de $0,02 \%$ e com valores de impacto médio de $137 \mathrm{~J}$ a $-2^{\circ} \mathrm{C}$. Uma alternativa bem próxima do E71T-1 seria o E71T-9, onde valores médios de $108 \mathrm{~J}$ a - 30 $\mathrm{C}$ podem ser

obtidos. É evidente que tais valores servem apenas como referência, pois os efeitos da diluição em juntas dissimilares produzem efeitos que apenas podem ser avaliados por soldagem e ensaios de peças de testes.

Entretanto, a alternativa mais indicada seria o emprego de consumíveis apropriados para a soldagem de juntas de ASTM A514 mesmo considerando uma soldagem dissimilar com aços C-Mn. Dentro deste contexto, os consumíveis com a adição de níquel merecem destaque. Diversos estudos e normas apontam que a presença de níquel até um teor máximo de 2,5\% atua no sentido de melhorar a tenacidade do metal de solda e ser efetivo na manutenção da temperatura de transição [15,46,68]. Deste modo, consumíveis com a classificação AWS A5.29 EXXXT5-K4 assumem um papel de destaque para tais aplicações. 


\section{CONCLUSÕES}

Tendo em vista os resultados obtidos pode-se concluir que:

a) Os fenômenos de carbonetação e descarbonetação ocorreram com maior intensidade na superfície oxicortada do ASTM A514

b) O teste CTS mostrou-se efetivo na confirmação da temperatura mínima de pré-aquecimento de $160^{\circ} \mathrm{C}$ para a junta soldada de ASTM A36 x ASTM A514.

c) Não houve redução significativa do limite de resistência da junta soldada após TTAT.

d) De acordo com a norma AWS D1.1/D1.1M:2010, a condição "como soldado" permite a qualificação de um procedimento de soldagem.

e) O metal de solda após TTAT apresentou baixos valores de tenacidade 0 que demonstra que o metal de adição E71T-1C não é adequado para aplicações a baixas temperaturas após sofrer este tipo de tratamento térmico.

f) Foi observada a presença de perlita no contorno de grão austenítico na região da ZAC do ASTM A514 na condição "como soldado" e a ocorrência de descarbonetação na mesma região após o tratamento térmico de alívio de tensões, no entanto tais indicações não apresentaram caráter deletério.

g) Foi identificada no metal de solda na região da raiz a presença do microconstituinte martensita-austenita na condição "como soldado", o que contribuiu para a redução da tenacidade nesta região.

h) Não ocorreram trincas intergranulares (indicativas da fragilização do revenido) tanto na ZAC quanto no metal de base ASTM A514. 


\section{REFERÊNCIAS BIBLIOGRÁFICAS}

[1] TELLES, P.C.S. Materiais para Equipamentos de Processo. Rio de Janeiro :Interciência, 2003. 275p.

[2] STANDARD Specification for Carbon Structural Steel: A36/A36M. American Society for Testing Materials, 2008.

[3] NORMA Standard Specification for High-Yeld-Strength, Quenched and Tempered Alloy Steel Plate, Suitable for Welding: A514/A514M. American Society for Testing Materials, 2005.

[4] CATÁLOGO Guidelines for Fabricating and Processing Plate Steel: Mittal Steel USA - Plate, 2006.

[5] Structural Welding Code - Steel: AWS D1.1/D1.1M. American Welding Society, 2010.

[6] NORMA Soldagem: N- 133, Revisão K. PETROBRAS. 2012

[7] ASM Metallographic Guide: Iron and Steels. ASM International.2002.

[8] COSTA E SILVA, A.L.V.; MEI, P.R. Aços e Ligas Especiais. São Paulo: Edgar Blücher, 2006. 646p.

[9] Placas de ligação A514. Catterpillar.

http://www.cat.com/en_GB/products/new/equipment/underground-room-and-pillar/facehaulers/18317150.html. Acessado em 18/12/2014

[10] Componentes estruturais em A514

http://www.astralloy.com/astralloy.infomedia.net/contentb68a.html?id=393929

Acessado em 18/12/2014.

[11] CHEN, C.C; POLLACK, A. Influence of Welding on Steel Weldment Properties. ASM Handbook, Vol. 6, Welding, Brazing and Soldering. ASM International, 2005.

[12] WAINER, E.; BRANDI, S.D.; MELO, F.D.H. Soldagem: Processos e Metalurgia. São Paulo: Edgard Blücher, 1995. 494p.

[13] KOU, S. Welding Metalurgy. Second Edition. New Jersey: John Wiley \& Sons, 2003. 461p.

[14] GRANJON, H. Les bases métallurgiques du soudage. Institut de Soudure: editeur PSA, 2000. 233p.

[15] LANCASTER, J.F. Metallurgy of Welding. Sixth Edition. Cambridge: Abington Publishing, 1999. 468p.

[16] SIGNES, E.G. A Simplified Method for Calculating Rates in Mild and Low Alloy Steel Weld Metals. Welding Journal. American Welding Society, Bulletin n.172, p.473484, May.1972. 
[17] AWS Handbook. Vol.I - Welding Metallurgy. American Welding Society. Miami: 1990.

[18] STANDARD Welding Terms and Definitions: AWS A3.0. American Welding Society, 2001.

[19] NATAL, Y.D. Soldabilidade de aços de alta Resistência e Baixa-Liga - ARBL. Associação Brasileira de Soldagem, 1993.

[20] WEGRZYN, T. Proposal of Welding Methods in Terms of the Amount of Oxygen. International Scientific Journal. World Academy of Materials and Manufacturing Engineering, Volume 47, p.57-61, Jan.2011.

[21] EVANS, G.M.; BAILEY, N. Metallurgy of Basic Weld Metal. First Edition. Cambridge: Abington Publishing, 1997. 432p.

[22] FARNEZE,H.N.; JORGE,J.C.F.; SOUZA, L.F.G.; BOTT, I.S. Estudo Comparativo de Metais de Solda de Aço Alta Resistência Obtidos pelos Processos Eletrodo Revestido e Arame Tubular para Aplicação em Equipamentos de Amarração Offshore. Revista Soldagem \& Inspeção. São Paulo, v.14, n. 2, p.151-160, Abr/Jun. 2009.

[23] ASM Handbook. Vol.6 - Welding, Brazing and Soldering . ASM International. 1990.

[24] BHADESHIA, H.K.D.H. About Calculating the Characteristics of the MartensiteAustenite Constituent. Proceedings of the International Seminar on Welding of High Strenght Pipelines Steels. CBMM and The Minerals, Metals and Materials Society, USA, p.99-106, 2013.

[25] GARLAND, J.G.; KIRKWOOD, P.R. The Notch Toughness of Submerged Arc Weld Metal in Micro Alloyed Structural Steels. British Steel Corporation. GS/PROD/499, 1974.

[26] SVENSSON, L.E; GRETOFT, B. Microstructure and Impact Toughness of C-Mn Weld Metals, 8p. Artigo - Welding Research Supplement, American Welding Society, 1990.

[27] GLOVER, A.G; McGRATH, J.T.; TINKLER, M.J.; WEATHERLY, G.C. The Influence of Cooling Rate and Composition on Weld Metal Microstructures in C/Mn and HSLA Steel, 8p. Artigo - Welding Research Supplement, American Welding Society, 1977.

[28] SAVAGE, W.F; NIPPES, E.F; SZEKERES, E.S. Hydrogen Induced Cold Cracking in a Low Alloy Steel, 8p. Artigo - Welding Research Supplement, American Welding Society, 1976. 
[29] GEDEON, S.A.; EAGAR, T.W. Assessing Hydrogen Assisted Cracking Modes in High Strength Steel Welds, 11 p. Artigo - U.S. Army Materials Technology Laboratory, 1988

[30] CAMPBELL, W.P. Experiences with HAZ Cold Cracking Tests on a C-Mn Structural Steel, 9p. Artigo - Welding Research Supplement, American Welding Society, 1973.

[31] STANDARD. Recommendations for welding of metallic materials. Part 2: Arc welding of ferritic steels. English Version of DIN EN 1011-2. Deutsche Norm, 2001.

[32] STANDARD Destructive tests on welds in metallic materials - Cold cracking test for weldments - Arc Welding Process - Parte 2: Self-restraint tests: ISO 17642-2. International Organization for Standardization, 2005.

[33] MESSLER, R.W. Principles of Welding: Process, Physics, Chemistry and Metallurgy. Weinheim: Wiley - VCH Verlag GmbH \& Co. KGaA, 2004. 689p.

[34] STOUT, R.D. Weldability of Steels. Welding Research Council. American Welding Society, 1987.

[35] LIŠČIĆ, B. Steel Heat Treatment. Steel Heat Treatment Handbook - Metallurgy and Technologies. Second Edition. CRC Press, Taylor\&Francis Group, 2007.

[36] HOLLOMON, J.H.;JAFFE, L.D., Ferrous Metallurgical Design. John Wiley and Sons Inc., 1947. 245 p.

[37] AFNOR, Influence des traitements thermiques après soudage sur les propriétés mécaniques des aciers pour chaudières et appareils à pression: NF A36-200. L'Association Française de Normalisation, 1982.

[38] DETEMPLE,I., Admissible post weld heat treatment conditions for pressure equipment made of dissimilar steel grades. Dillingen: Dillinger Hüttenwerke, 2015.

[39] SWIFT, R.A.; ROGERS, H.C. A Critical Review of Weld Metal Embrittlement., 17p. Artigo - Welding Research Supplement, American Welding Society, 1971.

[40] MANUAL Factors Affecting Quality in Oxy-Fuel Cutting: ESAB, 2006.

[41] AWS Handbook. Vol.2 - Welding Process - Arc and Gas Welding and Cutting, Brazing and Soldering. American Welding Society. Miami: 1990.

[42] GLIZMANENKO,D ; YEVSEYEV,G. Gas Welding and Cutting. Moscow: Peace Publishers, S/D.

[43] ADEDAYO, A.V. A Review of the Thermodynamics and Kinetics of Oxyfuel Gas Cutting of Steel. Welding Journal. Asian Journal of Materials Science, 2010.

[44] WOOD.W.E. Heat-Affected Zone Studies of Thermally Cut Structural Steels. FHWA-RD-93-015, U.S. Department of Transportation. 1994

[45] SPECIFICATION for Carbon Steel Electrodes for Flux Cored Arc Welding: A5.20-2010. American Welding Society, 2010 
[46] SPECIFICATION for Carbon and Low Alloy Steel Flux Cored Electrodes for Flux Cored Arc Welding and Metal Cored Electrodes for Gas Metal Arc Welding: A5.36/A5.36M-2012. American Welding Society, 2012

[47] STANDARD Specification for General Requirements for Rolled Structural Steel Bars, Plates, Shapes, and Sheet Pilling. A6/A6M-14. American Society for Testing Materials, 2014.

[48] SPECIFICATION for Welding Shielding Gases: A5.32-2010. American Welding Society, 2010

[49] STANDARD Methods for Determination of the Diffusible Hydrogen Content of Martensitic, Bainitic, and Ferritic Steel Weld Metal Produced by Arc Welding: ANSI/AWS A4.3-93 (R2006). American Welding Society, 2006.

[50] STANDARD Practice for Macroetching Metals and Alloys. E340-3. American Society for Testing Materials, 2013.

[51] STANDARD Test Method for Knopp and Vickers Hardness of Materials. E38411e1. American Society for Testing Materials, 2011

[52] STANDARD Test Methods and Definitions for Mechanical Testing of Steel Products. A370-13. American Society for Testing Materials, 2013.

[53] STANDARD Guide for Preparation of Metallographics Specimens. E3-11. American Society for Testing Materials, 2011.

[54] STANDARD Terminology Relating to Metallography. E7-09. American Society for Testing Materials, 2009.

[55] SLOTTMAN,G.V.; ROPER, E.H. Oxigen Cutting. New York: McGraw-Hill, 1951. First Edition. 407p

[56] WRIGHT.R.N. A modern Look at Decarburization. Rensselaer Polytechnic Institute. Final Report. Aug.2010

[57] THEWLIS, G. Classification and quantification of microstructures in steels. Institute of Materials, Minerals and Mining, Materials Science and Technology, Vol.20, Feb.2004.

[58] YURIOKA, N et al: Prediction of HAZ hardness of transformable steels. Metals Construction. 198719 (4) 217R-223R.

[59] Disponível em: http://www.twi-global.com/technical-knowledge/jobknowledge/mechanical-testing-tensiletesting-part-2-070/. Acesso em 22/06/2015.

[60] DIETER,G.E. Mechanical Metallurgy. McGraw-Hill Book Co: SI Edition, 1988. $751 \mathrm{p}$.

[61] Disponível em: http://calculations.ewi.org/VJP/MaterialsModeling.html. Acesso em 15/10/2015.

[62] ASM Handbook. Vol.12 - Fractography . ASM International. 1990. 
[63] SCHULZ-BEENKEN.A. Martensite in Steels: its Significance, Recent Developments and Trends.

[64] Boiler and Pressure Vessel Code: ASME Section IX - Qualification Standard for Welding and Brazing Procedures, Welders, Brazers, and Welding and Brazing Operators. American Society of Mechanical Engineers, 2015.

[65] BRAMFITT,B.L.; BENSCOTER,A.O. Common etchants for Iron and Steels., Artigo - Advanced Materials \& Process, ASM International, 2002.

[66] ZAKERINIA,H; KERMANPUR,A.; NAJAFIZADEH,A. Color metallography: a suitable method for characterization of martensite and bainite in multiphase steels, artigo - Vol.6, n.91, p 14-18, International Journa I of ISSI, 2009.

[67] KRAUSS,G. Martensite in steel: strength and structure, artigo - A273-275:4051, Materials Science and Engineering, Nov.1999.

[68] TRINDADE, V.B.; PARANHOS, R.P.R.; PAYAO, J.C.; SOUZA, L.F.G. Influência da adição de níquel na tenacidade de metais de solda de aços C-Mn antes a após tratamento térmico de alívio de tensões. Revista Soldagem \& Inspeção. São Paulo. Jan.2005. 


\section{ANEXO A}

Métodos para Determinação da Temperatura de Pré-Aquecimento Mínima

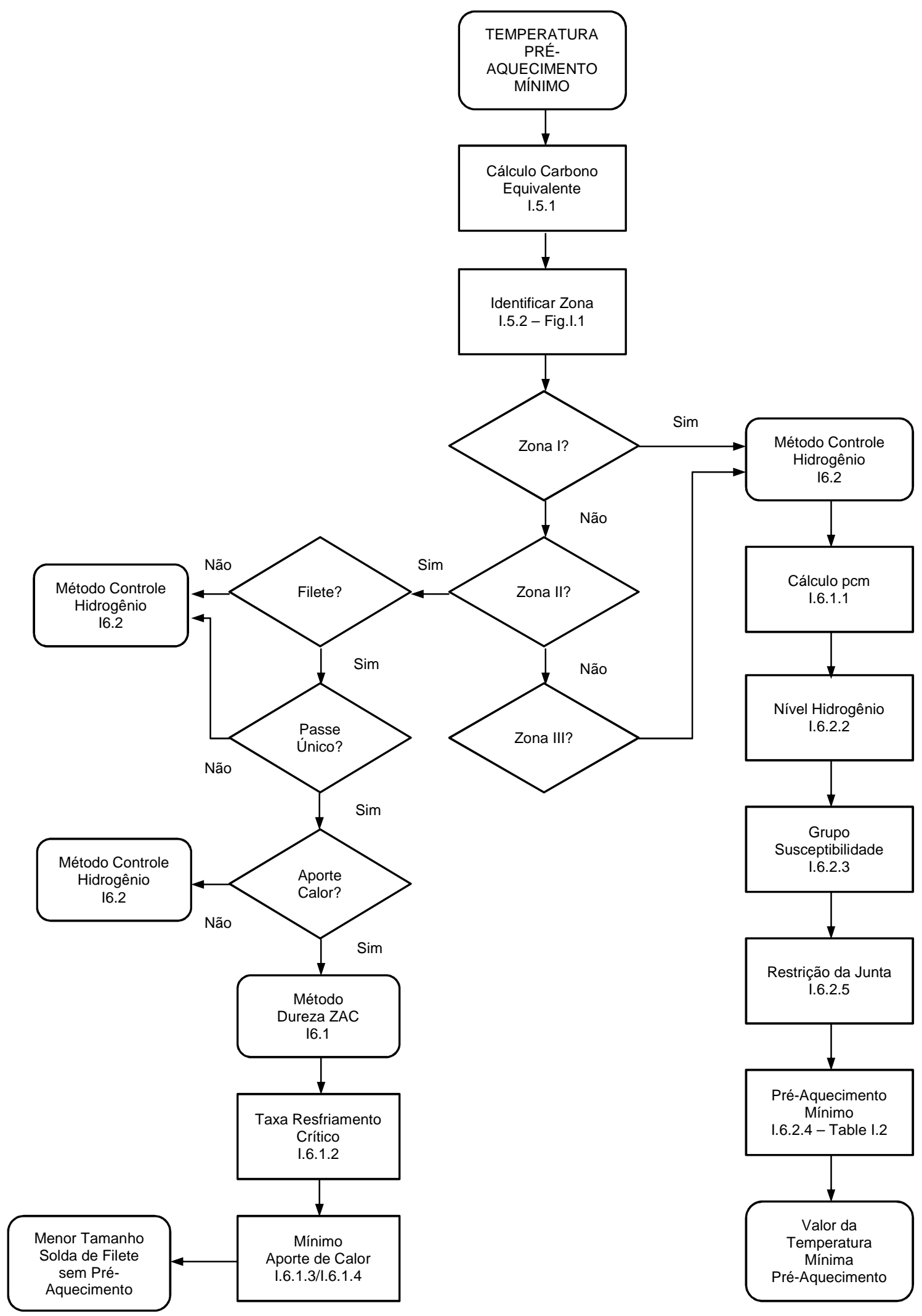


Table I.1

Susceptibility Index Grouping as Function of Hydrogen Level "H" and Composition Parameter $\mathbf{P}_{\mathrm{cm}}$ (see 16.2.3)

\begin{tabular}{|c|c|c|c|c|c|}
\hline \multirow{3}{*}{$\begin{array}{l}\text { Hydrogen } \\
\text { Level, H }\end{array}$} & \multicolumn{5}{|c|}{ Susceptibility Index ${ }^{b}$ Grouping ${ }^{c}$} \\
\hline & \multicolumn{5}{|c|}{ Carbon Equivalent $=\mathrm{P}_{\mathrm{cm}}^{\mathrm{a}}$} \\
\hline & $<0.18$ & $<0.23$ & $<0.28$ & $<0.33$ & $<0.38$ \\
\hline $\mathrm{HI}$ & A & B & $\mathbf{C}$ & D & $E$ \\
\hline $\mathrm{H} 2$ & B & $\mathrm{C}$ & D & $\mathrm{E}$ & $\mathrm{F}$ \\
\hline $\mathrm{H} 3$ & $\mathrm{C}$ & D & $\mathrm{E}$ & $\mathrm{F}$ & G \\
\hline
\end{tabular}

$=\mathrm{P}_{\mathrm{cm}}=\mathrm{C}+\frac{\mathrm{Si}}{30}+\frac{\mathrm{Mn}}{20}+\frac{\mathrm{Cu}}{20}+\frac{\mathrm{Ni}}{60}+\frac{\mathrm{Cr}}{20}+\frac{\mathrm{Mo}}{15}+\frac{\mathrm{V}}{10}+5 \mathrm{~B}$

${ }^{b}$ Susceptibility index $-12 \mathrm{P}_{\mathrm{cm}}+\log _{10} \mathrm{H}$.

'Susceptibility Index Groupings, A through G, encompass the combined effect of the composition parameter, $\mathrm{P}_{\mathrm{cm}}$, and hydrogen level, $\mathrm{H}$, in conformance with the formula shown in Note $\mathrm{b}$.

The exact numerical quantities are obtained from the Note $b$ formula using the stated values of $\mathrm{P}_{\mathrm{cm}}$ and the following values of $\mathrm{H}$, given in $\mathrm{ml} / 100 \mathrm{~g}$ of weld metal [see 16.2.2, (1), (2), (3)]:

$$
\mathrm{HI}-5 ; \mathrm{H} 2-10: \mathrm{H} 3-30 \text {. }
$$

For greater convenience, Susceptibility Index Groupings have been expressed in the table by means of letters, A through $\mathrm{G}$, to cover the following narrow ranges:

$$
\mathrm{A}=3.0 ; \mathrm{B}=3.1-3.5 ; \mathrm{C}=3.6-4.0 ; \mathrm{D}=4.1-4.5 ; \mathrm{E}=4.6-5.0 ; \mathrm{F}=5.1-5.5 ; \mathrm{G}=5.6-7.0
$$

These groupings are used in Table $\mathrm{I} .2$ in conjunction with restraint and thickness to determine the minimum preheat and interpass temperature.

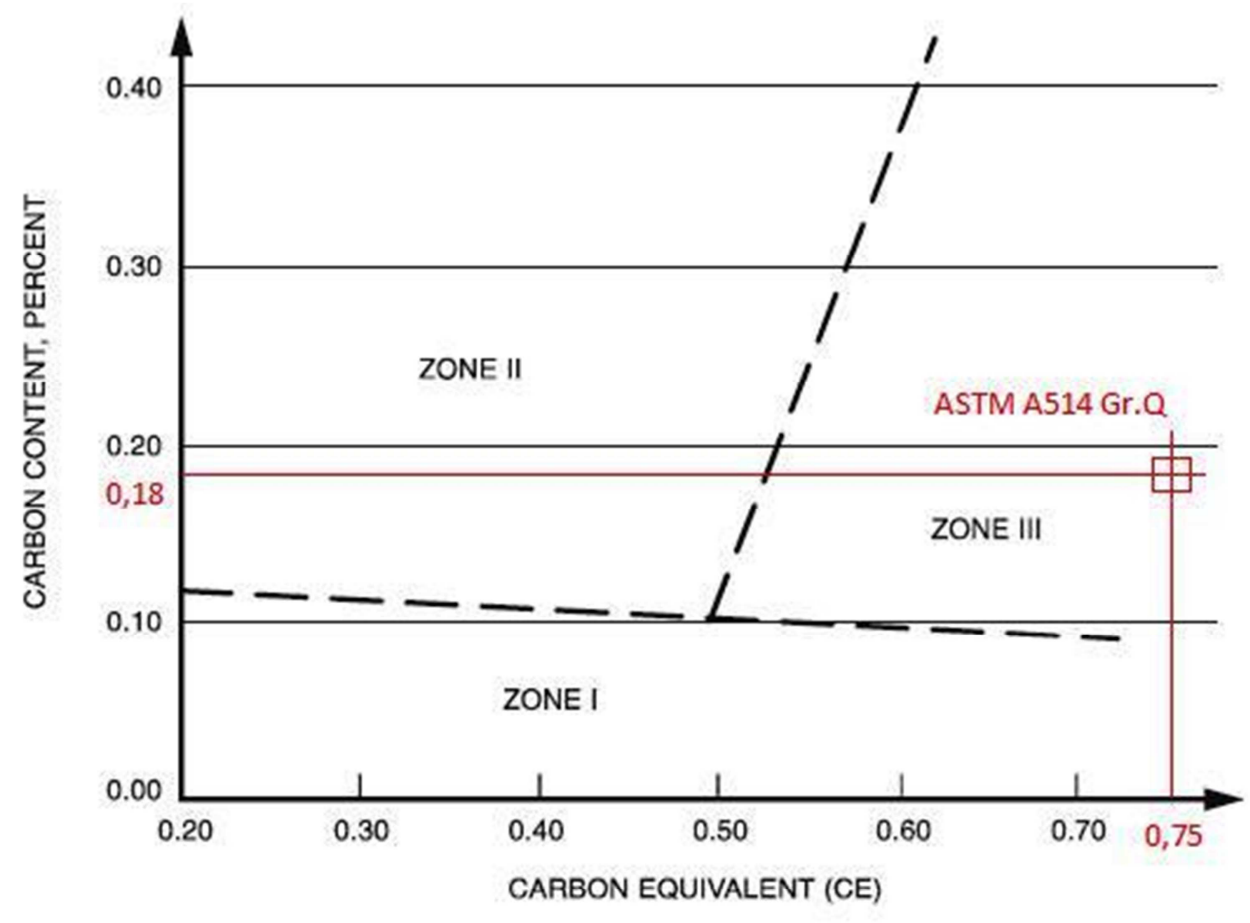

Notes:

1. $\mathrm{CE}=\mathrm{C}+(\mathrm{Mn}+\mathrm{Si}) / 6+(\mathrm{Cr}+\mathrm{Mo}+\mathrm{V}) / 5+(\mathrm{Ni}+\mathrm{Cu}) / 15$

2. See $15.2(1),(2)$, or (3) for applicable zone characteristics.

Figure I.1-Zone Classification of Steels (see I5.1) 


\section{ANEXO B}

\section{Cálculo da Temperatura de Pré-Aquecimento Mínima conforme a Norma DIN EN 1011-2, Método B}

Os efeitos da composição química caracterizado pelo carbono equivalente $(C E T)$, a espessura da chapa $d$, o teor máximo de hidrogênio difusível no metal de solda $H D$, o aporte de calor $Q$, podem ser agrupados na fórmula abaixo para fins de cálculo da temperatura mínima de pré-aquecimento:

$$
\mathrm{T}_{\mathrm{p}}=\mathrm{T}_{\mathrm{pCET}}+\mathrm{T}_{\mathrm{pd}}+\mathrm{T}_{\mathrm{pHD}}+\mathrm{T}_{\mathrm{pQ}}\left({ }^{\circ} \mathrm{C}\right)
$$

- Cálculo do CET

O CET segundo a norma DIN EN 1011-2 é dado pela fórmula abaixo:

$C E T=C+\frac{M n+M o}{10}+\frac{C r+C u}{20}+\frac{N i}{40}(\%)$

Assim, de acordo com os valores de composição química declarados nos certificado (Tabela XX) para o ASTM A514 Grau Q tem-se:

$C E T=0,18+\frac{1,02+0,40}{10}+\frac{1,00+0,04}{20}+\frac{1,21}{40}=0,40$

A relação linear existente entre o carbono equivalente CET e a temperatura de préaquecimento $T_{p}$ é mostrada na figura a seguir:

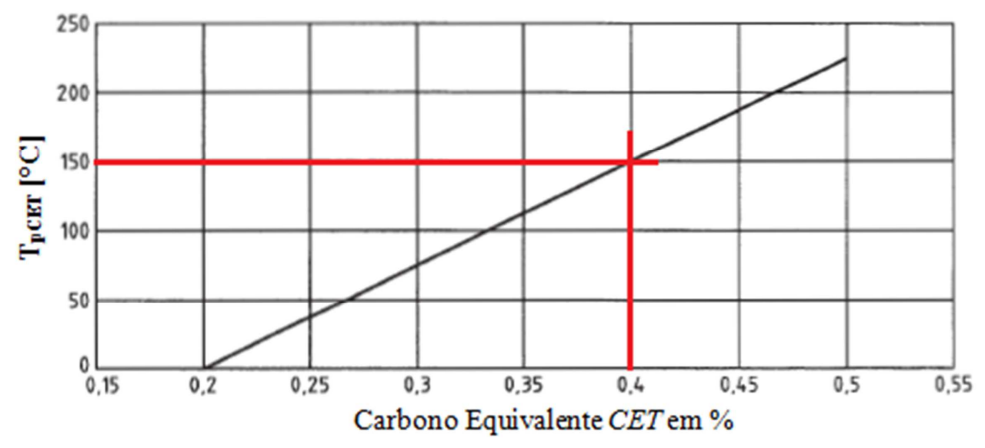

$T_{\text {pCET }}=750 . C E T-150=750.0,40-150=150^{\circ} \mathrm{C}$

Assim, $\mathrm{T}_{\mathrm{pCET}}=150^{\circ} \mathrm{C}$

- Espessura da Chapa 
A relação entre a espessura da chapa $d$ e a temperatura de pré-aquecimento $\mathrm{T}_{\mathrm{p}}$ é mostrada na figura a seguir:

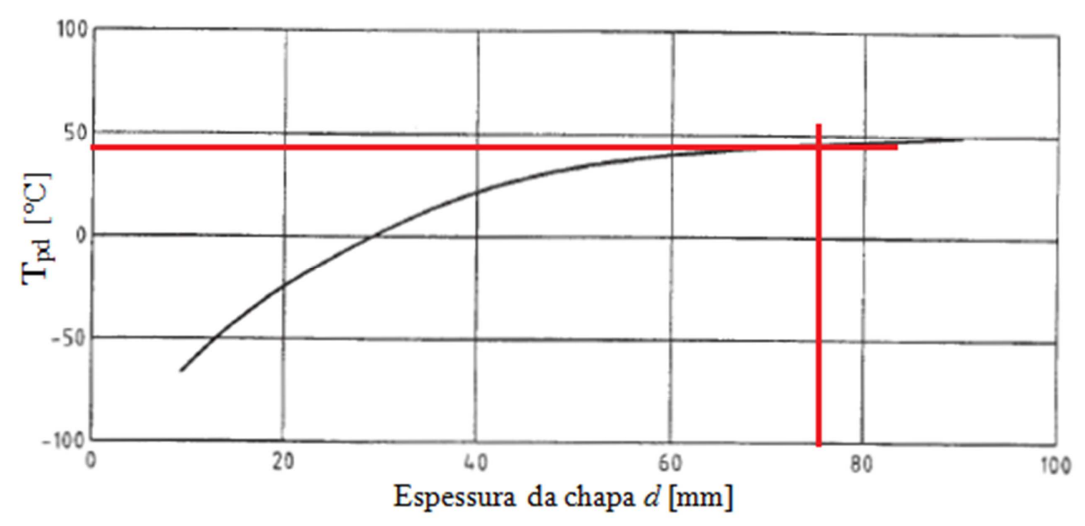

$T_{p d}=160 \cdot \tanh \left(\frac{d}{35}\right)-110=160+\left[\frac{\left(e^{\frac{76}{35}}-e^{-\frac{76}{35}}\right)}{\left(e^{\frac{76}{35}}+e^{-\frac{76}{35}}\right)}\right]-110=51^{\circ} \mathrm{C}$

Porém, pela análise do gráfico nota-se que para uma espessura de chapa de 76 $\mathrm{mm}$ a temperatura é inferior a $50^{\circ} \mathrm{C}$, mesmo assim ser á mantido o valor calculado algebricamente.

Assim, $\mathrm{T}_{\mathrm{pd}}=51^{\circ} \mathrm{C}$

- Teor de hidrogênio difusível máximo no consumível

O efeito do teor de hidrogênio difusível máximo do consumível na temperatura de pré-aquecimento é mostrado na figura a seguir:

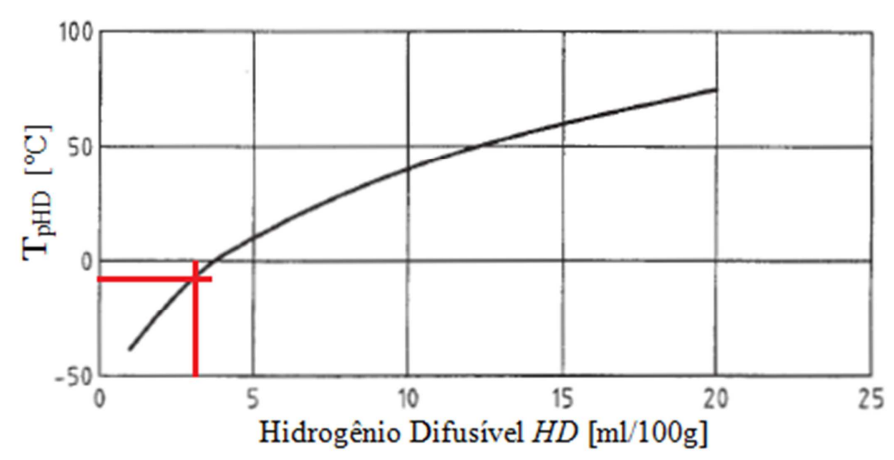


De acordo com a Tabela XX, o valor médio do teor de hidrogênio difusível máximo encontrado no consumível foi de 3,21 ml/100g.

$T_{p H D}=62 \cdot H D^{0,35}-100=62 \cdot 3,21^{0,35}-100=-6,7^{\circ} \mathrm{C}$

Assim, arredondando, $\mathrm{T}_{\mathrm{pHD}}=-7^{\circ} \mathrm{C}$

- Aporte de Calor

A influência do aporte de calor $Q$ na temperatura de pré-aquecimento é mostrada na figura a seguir:

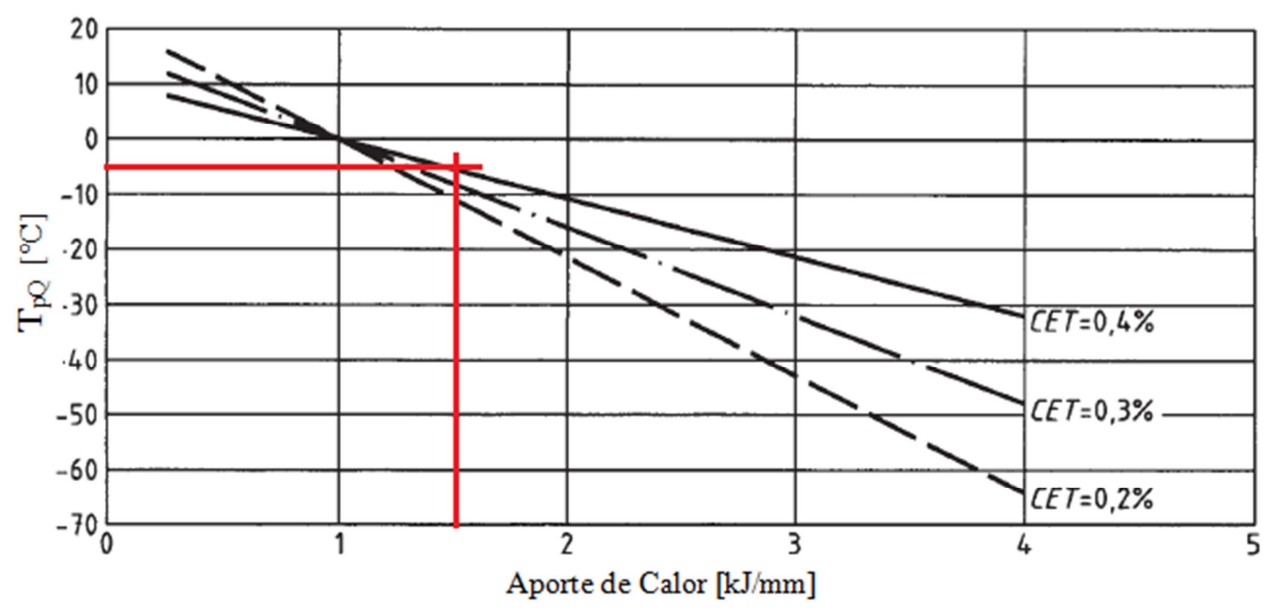

Considerando um aporte de calor médio de $1,5 \mathrm{~kJ} / \mathrm{mm}$, tem-se pelo gráfico que:

$$
\mathrm{T}_{\mathrm{pQ}}=-5^{\circ} \mathrm{C}
$$

Substituindo os valores encontrados de $T_{p C E T}, T_{p d}, T_{p H D}$ e $T_{p Q}$ na equação 1, temse que $T_{p}=189^{\circ} \mathrm{C}$. 
ANEXO C

Parâmetros e Sequência de Soldagem das Peças de Testes PT-04 \& PT-05

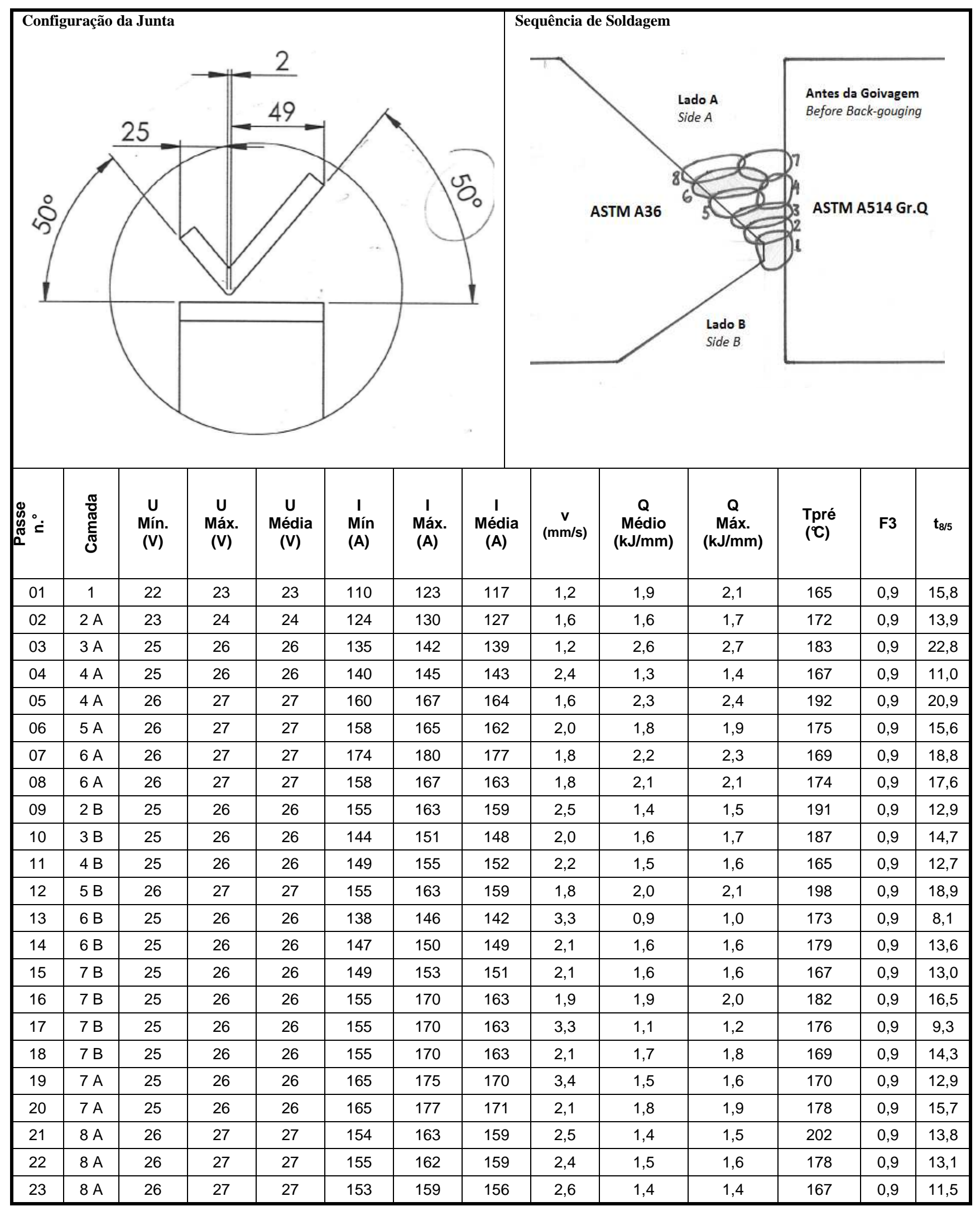




\begin{tabular}{|c|c|c|c|c|c|c|c|c|c|c|c|c|c|}
\hline 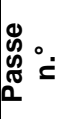 & 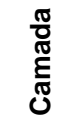 & $\begin{array}{l}\text { U } \\
\text { Mín. } \\
\text { (V) }\end{array}$ & $\begin{array}{l}\text { U } \\
\text { Máx. } \\
\text { (V) }\end{array}$ & $\begin{array}{c}\text { U } \\
\text { Média } \\
\text { (V) }\end{array}$ & $\begin{array}{l}\text { I } \\
\text { Mín } \\
\text { (A) }\end{array}$ & $\begin{array}{c}\text { I } \\
\text { Máx. } \\
\text { (A) }\end{array}$ & $\begin{array}{c}\text { I } \\
\text { Média } \\
\text { (A) }\end{array}$ & $\underset{(\mathrm{mm} / \mathrm{s})}{\mathbf{v}}$ & $\begin{array}{c}\text { Médio } \\
(\mathbf{k J} / \mathbf{m m})\end{array}$ & $\begin{array}{c}\text { Q } \\
\text { Máx. } \\
(\mathbf{k J} / \mathbf{m m})\end{array}$ & $\begin{array}{l}\text { Tpré } \\
\left({ }^{\circ} \mathrm{C}\right)\end{array}$ & F3 & $t_{8 / 5}$ \\
\hline 24 & $9 \mathrm{~A}$ & 26 & 27 & 27 & 174 & 180 & 177 & 2,9 & 1,4 & 1,4 & 178 & 0,9 & 11,8 \\
\hline 25 & $9 \mathrm{~A}$ & 26 & 27 & 27 & 165 & 172 & 169 & 3,0 & 1,3 & 1,3 & 166 & 0,9 & 10,5 \\
\hline 26 & $9 \mathrm{~A}$ & 26 & 27 & 27 & 178 & 186 & 182 & 2,7 & 1,5 & 1,6 & 191 & 0,9 & 13,8 \\
\hline 27 & $9 \mathrm{~A}$ & 26 & 27 & 27 & 166 & 172 & 169 & 3,1 & 1,2 & 1,3 & 189 & 0,9 & 11,2 \\
\hline 28 & $10 \mathrm{~A}$ & 26 & 27 & 27 & 178 & 181 & 180 & 3,0 & 1,3 & 1,4 & 177 & 0,9 & 11,6 \\
\hline 29 & $10 \mathrm{~A}$ & 26 & 27 & 27 & 157 & 161 & 159 & 3,0 & 1,2 & 1,2 & 175 & 0,9 & 10,2 \\
\hline 30 & $10 \mathrm{~A}$ & 26 & 27 & 27 & 174 & 179 & 177 & 3,3 & 1,2 & 1,2 & 178 & 0,9 & 10,4 \\
\hline 31 & $10 \mathrm{~A}$ & 26 & 27 & 27 & 180 & 184 & 182 & 2,3 & 1,8 & 1,8 & 189 & 0,9 & 16,2 \\
\hline 32 & $10 \mathrm{~A}$ & 26 & 27 & 27 & 185 & 189 & 187 & 3,4 & 1,3 & 1,3 & 192 & 0,9 & 11,6 \\
\hline 33 & $10 \mathrm{~A}$ & 26 & 27 & 27 & 168 & 174 & 171 & 3,8 & 1,0 & 1,1 & 178 & 0,9 & 8,9 \\
\hline 34 & $10 \mathrm{~A}$ & 26 & 27 & 27 & 174 & 181 & 178 & 3,3 & 1,2 & 1,3 & 188 & 0,9 & 10,9 \\
\hline 35 & $10 \mathrm{~A}$ & 26 & 27 & 27 & 169 & 175 & 172 & 3,1 & 1,3 & 1,3 & 195 & 0,9 & 11,7 \\
\hline 36 & $10 \mathrm{~A}$ & 26 & 27 & 27 & 172 & 175 & 174 & 3,2 & 1,2 & 1,3 & 173 & 0,9 & 10,5 \\
\hline 37 & $8 \mathrm{~B}$ & 26 & 27 & 27 & 178 & 182 & 180 & 3,7 & 1,1 & 1,1 & 185 & 0,9 & 9,9 \\
\hline 38 & $8 \mathrm{~B}$ & 26 & 27 & 27 & 176 & 182 & 179 & 3,9 & 1,0 & 1,1 & 168 & 0,9 & 8,6 \\
\hline 39 & $8 \mathrm{~B}$ & 26 & 27 & 27 & 179 & 181 & 180 & 5,1 & 0,8 & 0,8 & 174 & 0,9 & 6,8 \\
\hline 40 & $8 \mathrm{~B}$ & 25 & 26 & 26 & 174 & 179 & 177 & 4,9 & 0,8 & 0,8 & 185 & 0,9 & 6,9 \\
\hline 41 & $8 \mathrm{~B}$ & 25 & 26 & 26 & 175 & 177 & 176 & 3,9 & 1,0 & 1,0 & 201 & 0,9 & 9,3 \\
\hline 42 & $9 \mathrm{~B}$ & 25 & 26 & 26 & 157 & 162 & 160 & 3,2 & 1,1 & 1,1 & 176 & 0,9 & 9,3 \\
\hline 43 & $9 \mathrm{~B}$ & 25 & 26 & 26 & 140 & 144 & 142 & 3,4 & 0,9 & 0,9 & 194 & 0,9 & 8,5 \\
\hline 44 & $9 \mathrm{~B}$ & 25 & 26 & 26 & 144 & 152 & 148 & 3,5 & 0,9 & 1,0 & 174 & 0,9 & 7,9 \\
\hline 45 & $9 \mathrm{~B}$ & 25 & 26 & 26 & 146 & 150 & 148 & 2,5 & 1,3 & 1,3 & 189 & 0,9 & 11,5 \\
\hline 46 & $10 \mathrm{~B}$ & 22 & 23 & 23 & 134 & 140 & 137 & 3,5 & 0,8 & 0,8 & 171 & 1,0 & 6,4 \\
\hline 47 & $10 \mathrm{~B}$ & 22 & 23 & 23 & 139 & 145 & 142 & 3,1 & 0,9 & 0,9 & 168 & 1,0 & 7,4 \\
\hline 48 & $10 \mathrm{~B}$ & 23 & 24 & 24 & 137 & 142 & 140 & 3,5 & 0,8 & 0,8 & 194 & 1,0 & 7,5 \\
\hline 49 & $10 \mathrm{~B}$ & 23 & 24 & 24 & 137 & 145 & 141 & 3,3 & 0,9 & 0,9 & 175 & 1,0 & 7,4 \\
\hline 50 & $10 \mathrm{~B}$ & 23 & 24 & 24 & 139 & 144 & 142 & 4,1 & 0,7 & 0,7 & 178 & 1,0 & 6,0 \\
\hline 51 & $11 \mathrm{~A}$ & 26 & 27 & 27 & 148 & 154 & 151 & 3,4 & 1,0 & 1,0 & 168 & 0,9 & 8,4 \\
\hline 52 & $11 \mathrm{~A}$ & 26 & 27 & 27 & 142 & 146 & 144 & 3,5 & 0,9 & 1,0 & 194 & 0,9 & 8,7 \\
\hline 53 & $11 \mathrm{~A}$ & 26 & 27 & 27 & 145 & 152 & 149 & 3,5 & 1,0 & 1,0 & 176 & 0,9 & 8,3 \\
\hline 54 & $11 \mathrm{~A}$ & 26 & 27 & 27 & 146 & 149 & 148 & 3,0 & 1,1 & 1,1 & 172 & 0,9 & 9,3 \\
\hline 55 & $11 \mathrm{~A}$ & 26 & 27 & 27 & 148 & 152 & 150 & 2,8 & 1,2 & 1,3 & 194 & 0,9 & 11,4 \\
\hline 56 & $12 \mathrm{~A}$ & 26 & 27 & 27 & 144 & 151 & 148 & 3,6 & 0,9 & 1,0 & 186 & 0,9 & 8,3 \\
\hline 57 & $12 \mathrm{~A}$ & 26 & 27 & 27 & 148 & 153 & 151 & 3,6 & 0,9 & 1,0 & 194 & 0,9 & 8,8 \\
\hline 58 & $12 \mathrm{~A}$ & 26 & 27 & 27 & 147 & 150 & 149 & 3,3 & 1,0 & 1,1 & 182 & 0,9 & 9,1 \\
\hline 59 & $12 \mathrm{~A}$ & 26 & 27 & 27 & 145 & 147 & 146 & 3,0 & 1,1 & 1,1 & 168 & 0,9 & 9,1 \\
\hline 60 & $12 \mathrm{~A}$ & 26 & 27 & 27 & 145 & 148 & 147 & 2,6 & 1,3 & 1,3 & 173 & 0,9 & 10,8 \\
\hline 61 & $13 \mathrm{~A}$ & 26 & 27 & 27 & 146 & 152 & 149 & 3,3 & 1,0 & 1,1 & 190 & 0,9 & 9,3 \\
\hline 62 & $13 \mathrm{~A}$ & 26 & 27 & 27 & 139 & 142 & 141 & 3,9 & 0,8 & 0,8 & 184 & 0,9 & 7,3 \\
\hline 63 & $13 \mathrm{~A}$ & 26 & 27 & 27 & 145 & 151 & 148 & 3,8 & 0,9 & 0,9 & 182 & 0,9 & 7,9 \\
\hline 64 & $13 \mathrm{~A}$ & 26 & 27 & 27 & 148 & 150 & 149 & 3,1 & 1,1 & 1,1 & 178 & 0,9 & 9,5 \\
\hline 65 & $13 \mathrm{~A}$ & 26 & 27 & 27 & 148 & 151 & 150 & 2,6 & 1,3 & 1,3 & 164 & 0,9 & 10,6 \\
\hline 66 & $14 \mathrm{~A}$ & 26 & 27 & 27 & 154 & 161 & 158 & 2,7 & 1,3 & 1,4 & 192 & 0,9 & 12,0 \\
\hline 67 & $14 \mathrm{~A}$ & 26 & 27 & 27 & 142 & 147 & 145 & 3,1 & 1,0 & 1,1 & 166 & 0,9 & 8,6 \\
\hline 68 & $14 \mathrm{~A}$ & 27 & 28 & 28 & 148 & 155 & 152 & 3,1 & 1,2 & 1,2 & 182 & 0,9 & 10,3 \\
\hline
\end{tabular}




\begin{tabular}{|c|c|c|c|c|c|c|c|c|c|c|c|c|c|}
\hline 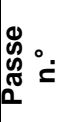 & 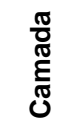 & $\begin{array}{l}\text { U } \\
\text { Mín. } \\
\text { (V) }\end{array}$ & $\begin{array}{l}\text { U } \\
\text { Máx. } \\
\text { (V) }\end{array}$ & $\begin{array}{l}\text { U } \\
\text { Média } \\
\text { (V) }\end{array}$ & $\begin{array}{l}\text { I } \\
\text { Mín } \\
\text { (A) }\end{array}$ & $\begin{array}{l}\text { I } \\
\text { Máx. } \\
\text { (A) }\end{array}$ & $\begin{array}{l}\text { I } \\
\text { Média } \\
\text { (A) }\end{array}$ & $\begin{array}{c}\mathbf{v} \\
(\mathrm{mm} / \mathrm{s})\end{array}$ & $\begin{array}{c}\text { Médio } \\
(\mathbf{k J} / \mathbf{m m})\end{array}$ & $\begin{array}{c}\text { Qúx. } \\
(\mathbf{k J} / \mathbf{m m})\end{array}$ & $\begin{array}{l}\text { Tpré } \\
\left({ }^{\circ} \mathrm{C}\right)\end{array}$ & F3 & $t_{8 / 5}$ \\
\hline 69 & $14 \mathrm{~A}$ & 27 & 28 & 28 & 154 & 162 & 158 & 2,4 & 1,6 & 1,6 & 202 & 0,9 & 15,1 \\
\hline 70 & $14 \mathrm{~A}$ & 26 & 27 & 27 & 152 & 158 & 155 & 3,2 & 1,1 & 1,1 & 184 & 0,9 & 9,8 \\
\hline 71 & $15 \mathrm{~A}$ & 26 & 27 & 27 & 161 & 165 & 163 & 3,1 & 1,2 & 1,2 & 178 & 1,0 & 10,4 \\
\hline 72 & $15 \mathrm{~A}$ & 26 & 27 & 27 & 134 & 146 & 140 & 3,5 & 0,9 & 1,0 & 165 & 1,0 & 7,4 \\
\hline 73 & $15 \mathrm{~A}$ & 26 & 27 & 27 & 136 & 142 & 139 & 3,4 & 0,9 & 0,9 & 170 & 1,0 & 7,7 \\
\hline 74 & $15 \mathrm{~A}$ & 26 & 27 & 27 & 139 & 143 & 141 & 3,9 & 0,9 & 0,9 & 182 & 1,0 & 7,3 \\
\hline 75 & $15 \mathrm{~A}$ & 26 & 27 & 27 & 142 & 147 & 145 & 3,2 & 1,0 & 1,1 & 176 & 1,0 & 8,8 \\
\hline 76 & $15 \mathrm{~A}$ & 26 & 27 & 27 & 136 & 142 & 139 & 3,4 & 0,9 & 1,0 & 180 & 1,0 & 8,2 \\
\hline
\end{tabular}

Consumível: Arame Tubular AWS A5.20 E71T-1C, bitola 1,2 mm.

Vazão do gás de proteção: 15 - $18 \mathrm{l} / \mathrm{min}$.

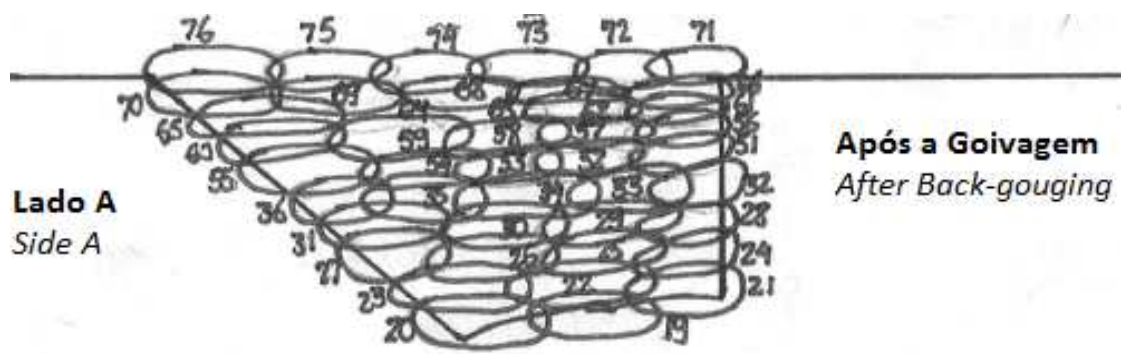

ASTM A36

ASTM A514 Gr.Q

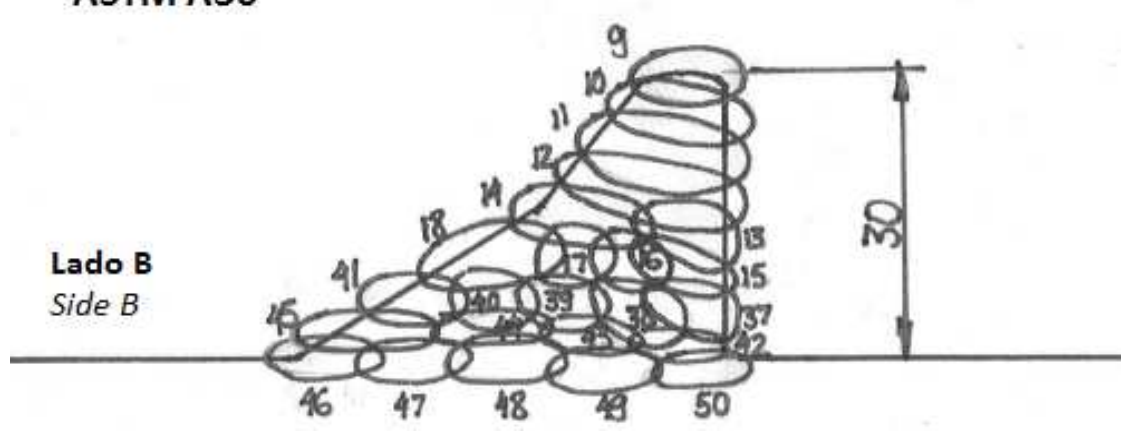

\section{Aporte de Calor}

$Q=\frac{\varepsilon \cdot U \cdot I}{v \cdot 1000}$

Onde:

$Q:$ Aporte de calor $[\mathrm{kJ} / \mathrm{mm}]$

$\varepsilon$ : Eficiência do arco $(\varepsilon=0,85 \mathrm{p} / \mathrm{FCAW})$

$U:$ Tensão [V]

$I:$ Corrente $[\mathrm{A}]$

$v:$ Velocidade de soldagem $[\mathrm{mm} / \mathrm{s}]$
Tempo de resfriamento entre $800^{\circ} \mathrm{C}$ e $500^{\circ} \mathrm{C}^{29}$

$t_{8 / 5}=\left(6700-5 T_{0}\right) \cdot Q \cdot\left(\frac{1}{500-T_{0}}-\frac{1}{800-T_{0}}\right) \cdot F_{3}$

Onde:

$t_{8 / 5}:$ Tempo de resfriamento entre $800^{\circ} \mathrm{C}$ e $500^{\circ} \mathrm{C}$ [s]

$T_{0}$ : Temperatura inicial da chapa $\left[{ }^{\circ} \mathrm{C}\right]$

$Q:$ Aporte de calor $[\mathrm{kJ} / \mathrm{mm}]$

$F_{3}:$ Fator de forma ${ }^{30}$

${ }^{29}$ Conforme norma DIN EN 1011-2, item D.6, Equação D.2 para aços não ligados e aços baixa-liga, na condição de transferência de calor tridimensional e tempo de resfriamento independente da espessura do material.

${ }^{30}$ Tabela D.1 da norma DIN EN 1011-2. 
Tabela C.1 - Influência da configuração da junta no tempo de resfriamento $t_{8 / 5}$.

Adaptado de [26].

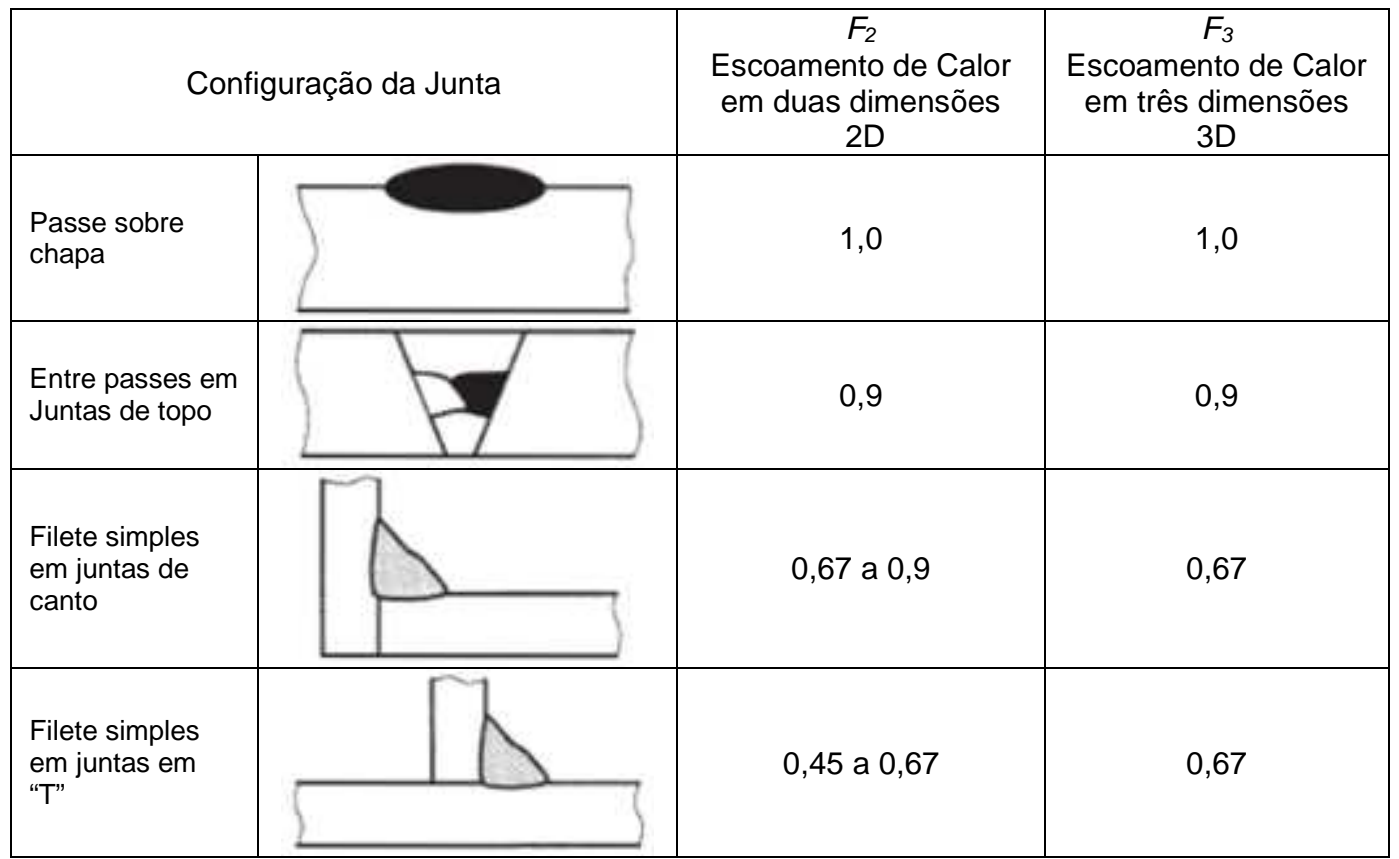

Os valores calculados de $t_{8 / 5}$ para cada passe podem ser conferidos através da Tabela $X$ que mostra 0 tempo de resfriamento $t_{8 / 5}$ em função do aporte de calor para diversas temperaturas de pré-aquecimento.

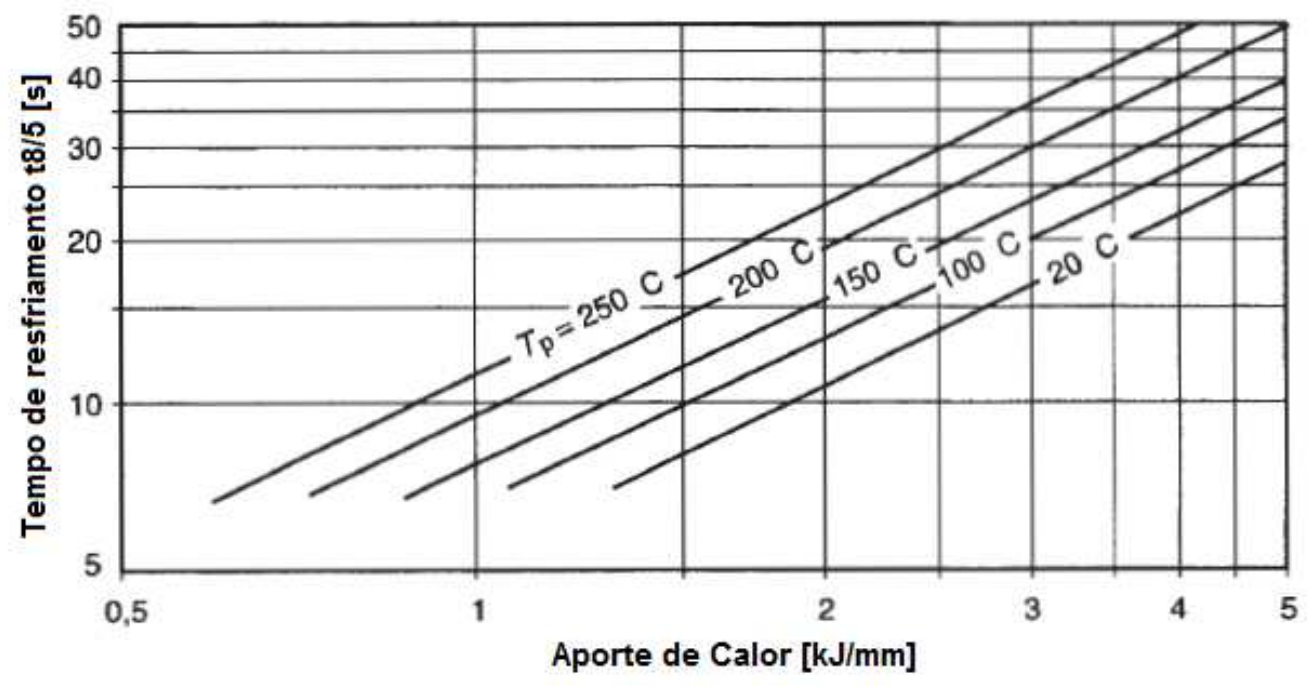

Figura C.1 - Tempo de resfriamento $t_{8 / 5}$ para escoamento de calor tridimensional em função do aporte de calor para diferentes temperaturas de pré-aquecimento. Adaptado de [26]. 
ANEXO D

Locais de Remoção dos Corpos de Prova nas Peças de Testes

(Baseado na norma AWS D1.1)

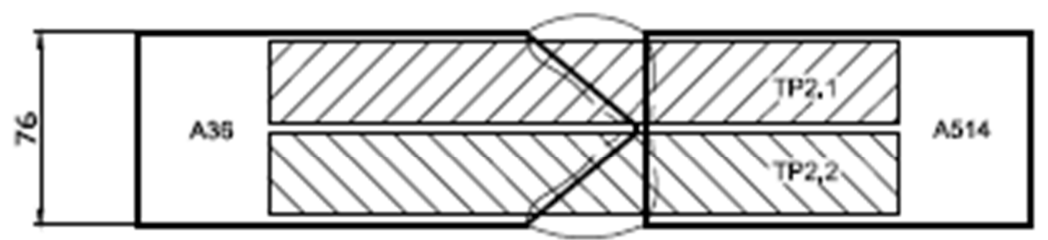

Cotte A-A

Diseçalo da Laminaçáso

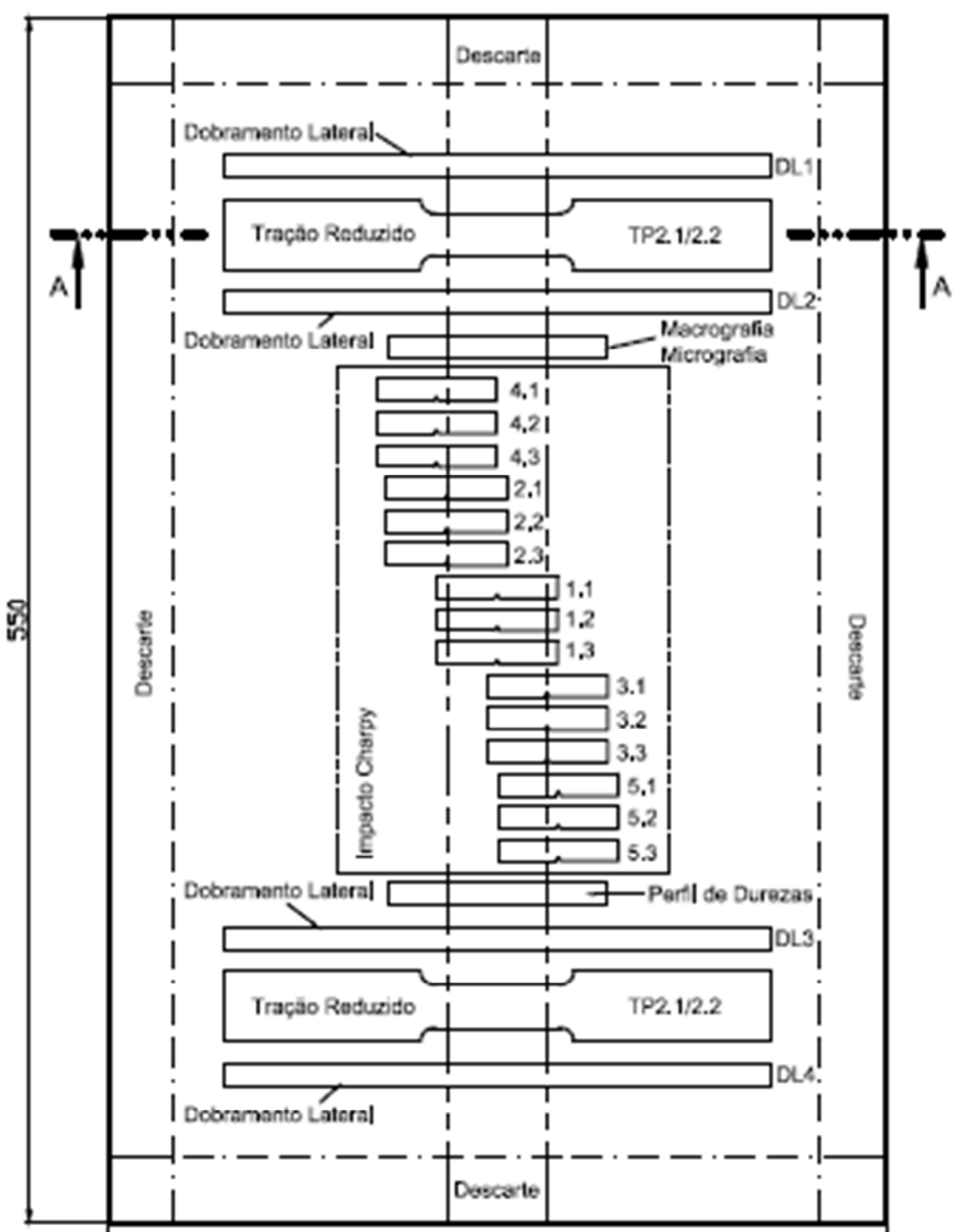




\section{ANEXO E}

\section{Cálculo da Previsão de Dureza na ZAC pelo Modelo de Yurioka}

1. Composição Química dos Metais de Base

$\mathrm{Na}$ tabela a seguir, de forma resumida, a composição química dos metais de base, em porcentagem em massa.

\begin{tabular}{c|c|c|c|c|c|c|c|c|c}
\hline $\begin{array}{c}\text { Elemento } \\
\text { MB }\end{array}$ & $\mathrm{C}$ & $\mathrm{Si}$ & $\mathrm{Mn}$ & $\mathrm{Cu}$ & $\mathrm{Ni}$ & $\mathrm{Cr}$ & $\mathrm{Mo}$ & $\mathrm{V}$ & $\mathrm{Nb}$ \\
\hline ASTM A36 & 0,17 & 0,33 & 1,14 & 0,01 & 0,01 & 0,03 & 0,00 & 0,002 & 0,002 \\
\hline ASTM A514 & 0,18 & 0,20 & 1,02 & 0,04 & 1,21 & 1,00 & 0,40 & 0,033 & 0,001 \\
\hline
\end{tabular}

2. Dados e Parâmetros de Soldagem

Segue abaixo os dados e parâmetros de soldagem utilizados no cálculo:

- corrente de soldagem, I = $115 \mathrm{~A}$;

- tensão de soldagem, $\mathrm{U}=23 \mathrm{~V}$

- velocidade de soldagem, $v=32 \mathrm{~cm} / \mathrm{min}=5,3 \mathrm{~mm} / \mathrm{s}$

- eficiência do arco, $\varepsilon=0,90 \%$ (FCAW)

- temperatura inicial da chapa, $T_{0}=16^{\circ} \mathrm{C}$

3. Cálculo do t $8 / 5$ (tempo de resfriamento entre $800^{\circ} \mathrm{C}$ e $500^{\circ} \mathrm{C}$ em segundos)

$t_{8 / 5}=\left(6700-5 T_{0}\right) \cdot Q \cdot\left(\frac{1}{500-T_{0}}-\frac{1}{800-T_{0}}\right) \cdot F_{3}$

Eq.C.1

$Q=\varepsilon \cdot E=\frac{\varepsilon \cdot U \cdot I}{v \cdot 1000}=\frac{0,90 \cdot 23 \cdot 115}{5,3 \cdot 1000}=0,449 \mathrm{~kJ} / \mathrm{mm}$

O fator F3 é atribuído conforme Tabela D.1 da norma DIN EN 1011-2 e, conforme esta tabela $F_{3}=0,67$. Assim,

$t_{8 / 5}=(6700-5 \cdot 16) \cdot 0,449 \cdot\left(\frac{1}{500-16}-\frac{1}{800-16}\right) \cdot 0,67=1,574 \mathrm{~s}$ 
3. Cálculo da Dureza (Modelo de Yurioka)

$H_{V}=\frac{H_{M}+H_{B}}{2}-\frac{H_{M}-H_{B}}{2,2} \cdot \arctan (x)$

Eq.C.2

$x=4 \cdot \frac{\log \left(t_{8 / 5} / t_{M}\right)}{\log \left(t_{B} / t_{M}\right)}-2$

Eq.C.3

onde:

$t_{8 / 5}:$ tempo de resfriamento entre $800{ }^{\circ} \mathrm{C}$ e $500{ }^{\circ} \mathrm{C}[\mathrm{s}]$

$H_{M}=884 \cdot C\left(1-0,3 C^{2}\right)+294$

Eq.C.4

$t_{M}=\exp \cdot\left(10,6 \cdot C E_{I}-4,8\right)$

Eq.C.5

$C E_{I}=C+\frac{S i}{24}+\frac{M n}{6}+\frac{C u}{15}+\frac{N i}{12}+\frac{M o}{4}+\frac{C r(1-0,16 \sqrt{C r})}{8}+f(B)$

Eq.C.6

$f(B)$ : fator de aumento da temperabilidade na ZAC devido ao boro. Neste trabalho $f(B)=0$.

$H_{B}=145+130 \cdot \tanh \left(2,65 \cdot C E_{I I}-0,69\right)$

$C E_{I I}=C+\frac{S i}{24}+\frac{M n}{5}+\frac{C u}{10}+\frac{N i}{18}+\frac{C r}{5}+\frac{M o}{2,5}+\frac{V}{5}+\frac{N b}{3}$

Eq.C.8

$t_{B}=\exp \left(6,2 \cdot C E_{I I I}+0,74\right)$

Eq.C.9

$C E_{I I I}=C+\frac{M n}{3,6}+\frac{C u}{20}+\frac{N i}{9}+\frac{C r}{5}+\frac{M o}{4}$

Eq.C. 10

\subsection{Cálculo da Dureza ZAC - ASTM A36}

Das Eq. C.6, C. 8 e C.10

$$
\begin{gathered}
C E_{I}=0,17+\frac{0,33}{24}+\frac{1,14}{6}+\frac{0,01}{15}+\frac{0,01}{12}+\frac{0,03(1-0,16 \sqrt{0,03)}}{8}=0,379 \\
C E_{I I}=0,17+\frac{0,33}{24}+\frac{1,14}{5}+\frac{0,01}{10}+\frac{0,01}{18}+\frac{0,03}{5}+\frac{0,002}{5}+\frac{0,002}{3}=0,420
\end{gathered}
$$




$$
\begin{aligned}
& C E_{I I I}=0,17+\frac{1,14}{3,6}+\frac{0,01}{20}+\frac{0,01}{9}+\frac{0,03}{5}=0,494 \\
& t_{M}=\exp \cdot(10,6 \cdot 0,379-4,8)=0,457 \\
& t_{B}=\exp (6,2 \cdot 0,494+0,74)=44,826 \\
& x=4 \cdot \frac{\log (1,574 / 0,457)}{\log (44,826 / 0,457)}-2=-0,921 \\
& H_{M}=884 \cdot 0,17\left(1-0,3 \cdot 0,17^{2}\right)+294=442,977 \\
& H_{B}=145+130 \cdot \tanh (2,65 \cdot 0,420-0,69)=145+130 \cdot \frac{e^{0,423}-e^{-0,423}}{e^{0,423}+e^{-0,423}}=196,929 \\
& H_{V A 36}=\frac{442,977+196,929}{2}-\frac{442,977-196,929}{2,2} \cdot \arctan (-0,921) \cong 403
\end{aligned}
$$

\section{$\therefore H_{v A 36} \cong 403 H V 5$}

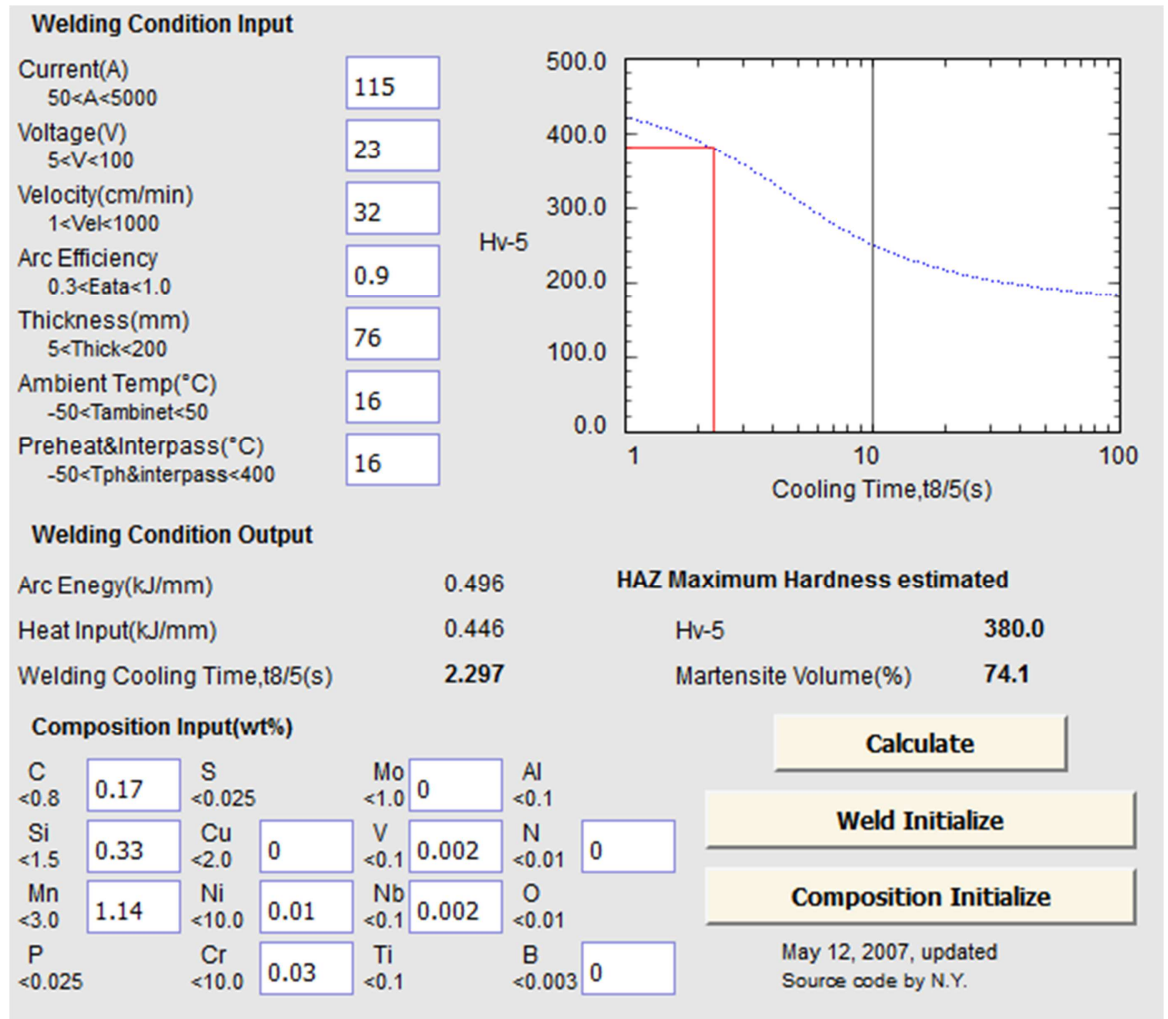




\section{ANEXO F}

\section{Cálculo do Parâmetro de Hollomon segundo a norma AFNOR NF A36-200}

O parâmetro de Hollomon é calculado conforme mostrado na equação a seguir:

$$
H=T \frac{(C+\log \tau)}{1000}
$$

Sendo:

$$
\tau=t+\frac{T}{\left[2,3 K_{1}\left(20-\log K_{1}\right)\right]}+\frac{T}{\left[2,3 K_{2}\left(20-\log K_{2}\right)\right]}
$$

Onde $\mathrm{H}$ é o parâmetro de Hollomon-Jaffe, C é uma constante, T é a temperatura de patamar em $\mathrm{K}, \mathrm{t}$ é o tempo de patamar em $\mathrm{h}, \mathrm{K}_{1}$ é a taxa de aquecimento em $\mathrm{K} / \mathrm{h}$ e $\mathrm{K}_{2}$ é a taxa de resfriamento em $\mathrm{K} / \mathrm{h}$. Na prática adota-se um valor de $\mathrm{C}=20$ para aços C-Mn e aços baixa-liga [3].

Os parâmetros do TTAT empregados na peça de testes PT-04 estão descritos na tabela a seguir:

\begin{tabular}{l|c}
\hline \multicolumn{1}{c|}{ Parâmetros } & Valores Obtidos \\
\hline Taxa de aquecimento $-\mathrm{K}_{1}$ & $323 \mathrm{~K}$ \\
\hline Temperatura de patamar $-\mathrm{T}$ & $873 \mathrm{~K}$ \\
\hline Tempo de patamar $-\mathrm{t}$ & $6,0 \mathrm{~h}$ \\
\hline Taxa de resfriamento $-\mathrm{K}_{2}$ & $373 \mathrm{~K}$ \\
\hline
\end{tabular}

Substituindo os valores descritos na tabela na equação, tem-se:

$$
\begin{aligned}
& \tau=6+\frac{873}{[2,3.323(20-\log 323)]}+\frac{873}{[2,3.373(20-\log 373)]}=6,12 \\
& H=873 \frac{(20+\log 6,12)}{1000}=18,1
\end{aligned}
$$


$\mathrm{O}$ valor obtido de $\mathrm{H}$ plotado no gráfico representado pela Figura $\mathrm{C} .1$ fornece um valor de $5 \%$ na redução do limite de resistência do material após o TTAT.

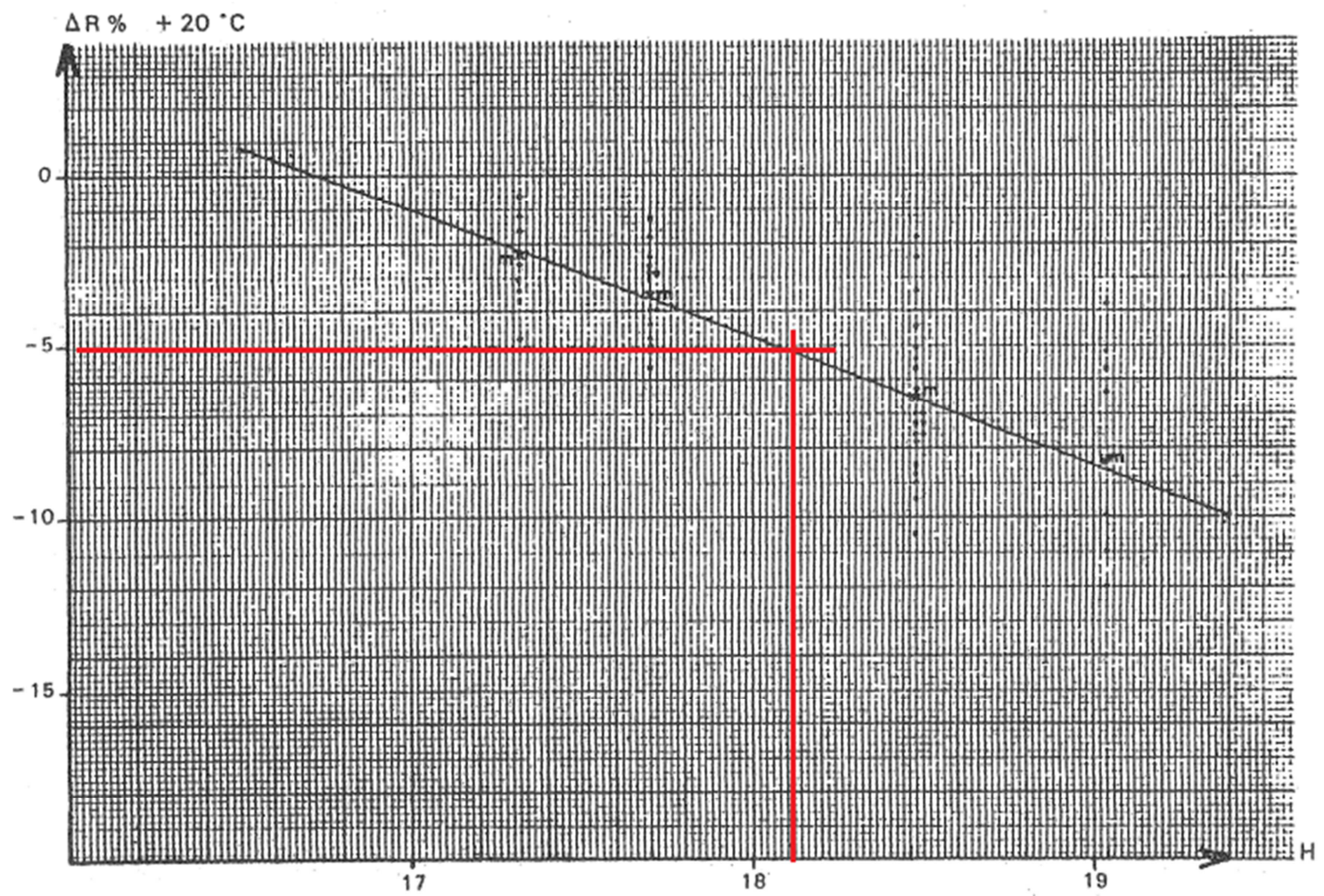

Na tabela a seguir são mostrados os valores dos limites de resistência obtidos no ensaio de tração.

\begin{tabular}{c|c|c}
\hline \multirow{2}{*}{ Corpo de Prova } & \multicolumn{2}{|c}{$\begin{array}{c}\text { LR } \\
\text { [MPa] }\end{array}$} \\
\cline { 2 - 3 } & $\begin{array}{c}\text { PT-03 } \\
\text { S/TTAT }\end{array}$ & $\begin{array}{c}\text { PT-04 } \\
\text { C/ TTAT }\end{array}$ \\
\hline TP1.1 & 515 & 487 \\
\hline TP1.2 & 524 & 489 \\
\hline TP2.1 & 514 & 489 \\
\hline TP2.2 & 522 & 491 \\
\hline Média & 519 & 489 \\
\hline S & 5,0 & 1,6 \\
\hline
\end{tabular}

